\title{
BRITAIN, SWEDEN AND THE COLD WAR $1945-54$
}

\author{
Juhana Aunesluoma \\ St Antony's College
}

Thesis submitted to the Faculty of Modern History, University of Oxford in conformity with the requirements for the degree of Doctor of Philosophy

Hilary Term 1998

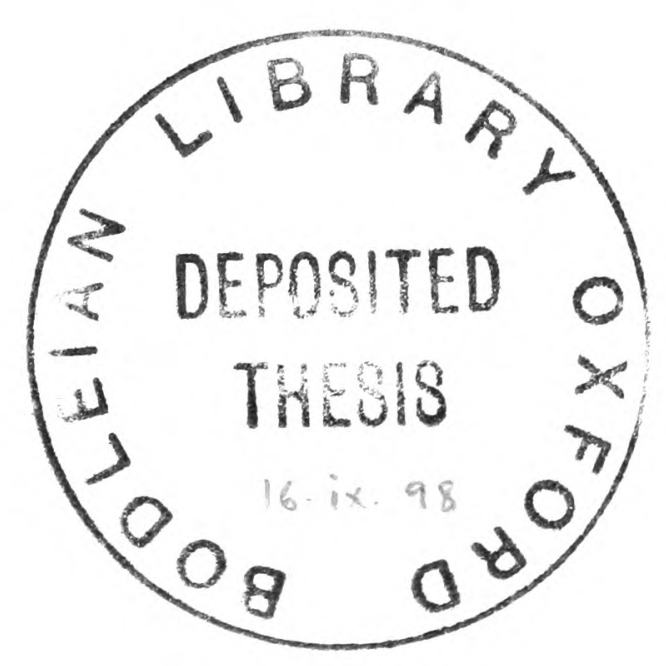




\section{ACKNOWLEDGEMENTS}

This thesis would never have been completed without the help of many individuals and organisations. First and foremost my thanks are due to my supervisor in Oxford, Dr. Anne Deighton, whose commitment to fulfill this role not only exceeded any expectations a graduate student might have, but also provided the exacting standards and the solid base of support, that were needed throughout the various stages of this work. Thanks are also due to her for her invaluable help in giving my English more authenticity and precision than a native Finnish speaker could achieve alone. I am also grateful for the generous support of the Finnish Academy which provided the financial means for me to study in Oxford. The Väinö Tanner Foundation helped me to embark upon a doctorate, and the Helsingin Sanomat Centenary Foundation was instrumental in ensuring that I completed it. Professor meritus Jukka Nevakivi and Dr. Mikael af Malmborg both provided me with encouragement, advice and later useful comments on the draft text. Thanks are also due to Professor Alan Milward whose advice and whose seminars in Florence helped me to weave together the complex realms of international political economy and foreign policy. Dr. Martti Häikiö's help and support began long before I ever dreamt of continuing my studies as far as they finally took me. He not only taught me invaluable lessons about the historian's craft, but also let me practise them as well. Without those long conversations with Mikko Majander in the car from Oxford to Kew about history, jazz, sports and life in general, my work would have been far less interesting, and without my friends in St Antony's, Helsinki and elsewhere I would have not enjoyed graduate life as much as I did. But, in the end, my greatest indebtedness is to the person who experienced most closely the strains this work caused, and put up with the long separations it required. Hence, this work is dedicated to Kristiina, for not letting me forget where home always was. 


\section{ABSTRACT \\ BRITAIN, SWEDEN AND THE COLD WAR, 1945-54 \\ Juhana Aunesluoma, St Antony's College \\ D.Phil-thesis, Hilary Term 1998}

This thesis explores the ways in which British policy contributed to Sweden's Western connection in the early cold war. It considers the extent to which an analysis of British policy is necessary to an understanding of how the cold war shaped the Nordic region and whether there was a special part for Britain in the ways in which Sweden sought to be bound to the Western powers economically, politically and militarily.

A central conclusion is that British policy was instrumental in establishing the conditions whereby Sweden could reconcile the conflicting demands of its official foreign policy of neutrality with the reality of its economic, cultural and ideological Western orientation. Swedish military nonalignment did not lead to international isolation, and until US policy changed in 1952 and a more positive approach towards Sweden was officially adopted, Britain remained the primary link between Sweden and the Western alliance. This was seen in almost every aspect of Sweden's Western connection. Swedish defences were built with British high technology, material and assistance. Service level exchanges kept both parties abreast of developinents in defence planning and in questions of cold war grand strategy, and tacitly facilitated coordination of plans. On the economic front, Britain was a large scale trader of strategic goods to and from Sweden, and the Labour government's policy of fostering closer institutional relations with Sweden was particularly important in the work of the OEEC and in a specific Anglo-Scandinavian forum, Uniscan. In achieving a rough power balance in the north, Swedish cooperation was essential although its neutrality policy did not have to be challenged openly.

The work is based on primary material from the Foreign Office archives, the archives of the Ministry of Defence, Board of Trade, Treasury, Bank of England, Cabinet and the service departments. In Sweden the Foreign Ministry archives and archives of other civilian and military authorities have been used. 


\section{ABSTRACT}

BRITAIN, SWEDEN AND THE COLD WAR, 1945-54.

This thesis explores the ways in which British policy contributed to Sweden's Western connection in the early cold war. It considers the extent to which an analysis of British policy is necessary to an understanding of how the cold war shaped the Nordic region and whether there was a special part for Britain in the ways in which Sweden was sought to be bound to the Western powers economically, politically and militarily. It deals with the establishment of a regional balance that lasted throughout the conflict. It touches closely upon the problem of Britain's character as a postwar world power; its general role in the origins and the first phase of the cold war; in building Western cooperation politically and institutionally; and the nature of its power in an era of systemic change. By concentrating on British policy, this thesis contributes to a more nuanced picture both of great power interests in Scandinavia in general and of the external environment in which Sweden's neutrality policy was pursued.

Sweden's policy of neutrality posed a particular set of problems for the Western powers in the early cold war. Swedish foreign policy had a bearing upon Scandinavia's overall political strength and cohesion in the shadow of the East-West divide; its economic, political and cultural ties with the West; and indeed, the region's general defensive capability. The US took an increasingly critical attitude towards Sweden when cold war divisions were hardening in 1947. As Norway and Denmark joined the Atlantic Pact in 1949, the Western powers gained a firm foothold in Scandinavia, but what has been labelled the cold war Nordic balance was not achieved until later. The key issue was whether or not a modus vivendi could be reached with a militarily nonaligned Sweden.

Interest previously has been channelled into the study of US not British foreign policy, and on Norway and Denmark rather than Sweden, especially for the period 1945- 
49. Cold war military strategy and security policy in general has tended to dominate studies. Recently more research has appeared on the 1950s, but this largely concentrates on US, Norwegian and Danish policies. In the works where British policy has been analysed the main focus has been on the years 1947-49, giving Anglo-Norwegian relations particular attention. The failed attempt in 1948 to achieve a compromise between a neutral Scandinavian defence union and Norway's and Denmark's membership in the Atlantic pact without Sweden, is the best known aspect of Britain's involvement in the region after the war. Although there exists previous work on Britain's postwar bilateral trade relations with Sweden and Denmark, the linkages between foreign policy, the cold war and economic considerations have not been sufficiently analysed. In the recent work of the governmental Neutrality Policy Commission in Sweden, newly opened British primary material was used for the Korean War period, but instead of analysing British policy it was used to find out how far Sweden was prepared to receive military help from the West in a future conflict. Until very recently, Sweden's postwar international position has been one of the least researched topics in Scandinavian political history, as has British policy prior to 1947 and especially after 1949.

The thesis is based on primary material from the Foreign Office archives, the archives of the Ministry of Defence, Board of Trade, Treasury, Admiralty, Air Ministry, Bank of England and the Cabinet as a whole. Official material has been augmented with private papers, newspapers and periodicals, contemporary literature and other published material in Britain and elsewhere. New or previously very little used material falls in three main categories. First, sensitive FO and Ministry of Defence documentation concerning Britain's policy towards Sweden during the Korean War was made available in 1994-96. This material has been instrumental in establishing the position of Sweden in British policy and in assessing the degree and nature of the confidential military exchanges that took place. It also reveals the full extent to which the British were 
involved in defining Scandinavia's and Sweden's place in Western defence during a key period of the consolidation of NATO. Although most of the new evidence is for the period after the signature of the Atlantic pact, new FO and COS material has also been released for the pre-1949 period. Second, the archives of the Swedish civilian and military authorities have slowly been opened for researchers from 1992 onwards. Of these, the archives of the Swedish Foreign Ministry and the military authorities have been the most useful for this research. In Finland Foreign Ministry material was opened for research in 1992 and it has been used to bring additional perspectives to the main substance of the thesis. The third part of the previously unused or very little used material consists of the archives of bodies other than the Northern Department in the Foreign Office, opened either according to the 30-year rule or by the author's request. These include: the Mutual Aid department, Economic Relations department, different Cabinet committees as well as the original Cabinet papers, the Board of Trade and Treasury archives, the Bank of England archives, the private office papers of Ernest Bevin, Herbert Morrison and Anthony Eden and a number of other collections of private papers in different repositories in the UK and elsewhere. The wealth of documentation over and above the activities of the FO's Northern Department has enabled a fuller construction of both the making of British foreign policy, its implementation, and influence. Unpublished American documents from various presidential libraries and the National Archive in Washington D.C. have been consulted in Stockholm, where a reprographic collection is housed in the Central Archive of the Swedish Government, including material declassified in 1989-1994. The situation regarding primary material can be considered as very satisfactory, and substantially better than was the case prior to 1992-94. The most significant omissions in the source material are original intelligence material, NATO's operational planning papers and the personal diaries of the Swedish premier Tage Erlander. 
The main methodological point of departure has been to see the topic beyond the rather narrow remit of traditional diplomatic history. In this respect the challenge to a methodologically up-to-date international history has been interpreted as an increased need for a greater sensitivity to the complex interplay between the structural, material basis of international relations and the history of political events. There is also a need for greater sophistication in analysing the making of foreign policy, its background influences, machinery and the bureaucratic and domestic sphere in general. Also the changes in the arena of diplomacy itself, such as were found in the new forms of international institutional cooperation that took strongly root in the West after the Second World War, and the influence of international cooperation beyond what had been customary in traditional pre-1939 diplomacy has to be taken into account.

The main conclusions will be shown to be that British policy was instrumental in establishing the conditions whereby Sweden could reconcile the conflicting demands of its official foreign policy of neutrality with its basic economic, cultural and ideological Western orientation. Swedish military nonalignment did not lead to international isolation, and until US policy changed in 1952 and a more positive approach towards Sweden was adopted, Britain remained the primary link between Sweden and the Western alliance. This was seen in almost every aspect of Sweden's Western connection. Swedish defences were built with British high technology, materiel and assistance. Service level exchanges kept both parties abreast of developments in defence planning and in questions of cold war grand strategy, and tacitly facilitated coordination of plans. On the economic front, Britain was a large scale trader of strategic goods to and from Sweden, and its policy of fostering closer institutional relations with Sweden was particularly important in the work of the OEEC and in a specific Anglo-Scandinavian forum, Uniscan. All this indicates that to keep Sweden as close as possible to the Western powers was of special concern for Labour government ministers, defence planners, economic experts and 
diplomats. In achieving a rough power balance in the north, Swedish cooperation was essential although its neutrality policy did not have to be challenged openly.

Neutrality was not in itself opposed by postwar foreign policy makers in Britain. This contrasted strikingly with the Americans' attitude, which became increasingly hostile after 1941 when they themselves abandoned their long tradition of neutrality. The attitude towards Swedish foreign policy was in keeping with the pragmatic tradition of British foreign policy making, although the limited leverage of Britain or other foreign powers over Sweden was realised in London. The ultimate, if increasingly distant, goal for British policy was Sweden's closer and open alignment with the West, even at the expense of upsetting the fragile regional balance that was slowly consolidated after 1949. Again in contrast to the US, the British were more willing to leave Finland to the Soviet sphere and to consider the region in terms of a spheres of influence arrangement. The survival of Finland alongside the Soviet Union was eventually welcomed in London, but it was an extra bonus and should not be confused with the motivations of British policy. These placed Sweden's Western connection firmly ahead of Finland. In this respect, the Swedish foreign ministry's often used 'Finland's argument' had only very limited impact on British policy. The reasons for the acceptance of Sweden's foreign policy lay elsewhere.

While the aim of Sweden's open alignment with the West seemed increasingly unattainable, the British were willing to settle with the status quo, and to influence Sweden's position at a lower level, gradually, and step by step. This involved the acceptance of Swedish neutrality as an integral part of the regional balance, as long as Sweden was economically and, short of politically binding commitments, ideologically clearly a part of the larger group of Western nations. What was even more significant was that its military non-alignment was considered less of a problem if the basic assumptions behind defence planning, the unlikelihood of Sweden to escape from an all- 
out East-West war, were shared in the West as well as in Sweden. That this was the case, became the perception in Britain during the Korean War, but as Sweden was not a secret NATO-member in terms of security guarantees, it retained its ultimate freedom of action in times of crisis as well as in peace. Moreover, from the British point of view, the need to integrate Swedish defences more firmly with those in NATO became less urgent with West German rearmament and the overall amelioration of international tension in 1954-55. Together with the firm attachment of Sweden to the West on the nonmilitary sphere in general, made it a neutral bulwark against Soviet ideological intrusions, closely linked to the West, but with its neutral status shielding the precarious politico-strategic balance in the Nordic region. It showed that peacetime neutrality policy in geopolitically sore spots could have its uses for the West, if adjusted suitably.

The right approach to Swedish neutrality became an issue in Anglo-American relations as well. How the Western powers approached Sweden's policy of neutrality was illustrative of the ways in which neutrality became an established fact in the cold war international system. If it was accepted as a political reality, it was also adapted, adjusted and effectively contained in Europe. A central argument is that the search for a modus vivendi with neutral Sweden started first in Britain, which later contributed to the conditions where both the United States and the Soviet Union had to adjust their policies towards cold war neutrality in Europe. That the US finally in 1952 officially acknowledged Swedish neutrality as a political reality in cold war Europe finally brought the two Western powers most closely involved in the region in step with each other. The disagreements that had existed from 1947, when US interest in the region rose, were then solved. This removed a serious obstacle for the British policy of fostering closer and confidential relations with the Swedes in the shadow of neutrality, and the Americans gradually assumed a greater role in both the material-technical military field with Sweden, and politically as a sponsor of the status quo in the Nordic region. 
Two simultaneous processes defined the overall terms of reference of Britain's interests in Sweden and the region as a whole: Britain's own political and economic ambitions concerning its great power status, and the worsening of relations with the Soviet Union after 1945. But Britain's political and economic interest in Scandinavia was not firstly dependent on developments in East-West relations. The cold war made the consolidation of Britain's interests in Scandinavia more urgent, and in particular brought strategic considerations into play, but Scandinavia remained a sideshow. The persistence of the British involvement in the region after the US made their historic commitment in 1949 is at least partly explained by Britain's interests in the north that were not only a function of the cold war. As in many other areas, British postwar foreign policy faced a double challenge in Scandinavia: to tie the Americans firmly to the economic and military defence and consolidation of the region - in terms that the Scandinavians could themselves accept - but also to ensure that Britain's own vital interests were not compromised. Both British economic and strategic interests gave hardly any room for a policy of isolation towards Sweden, and if the US tried this, it had to be countered. This provided Sweden with a window of opportunity to consolidate its international position after 1949, and became the remaining legacy of British policy.

The main originality of the thesis can be summarized in five main points. First, it sheds new light to the character of Britain as a mediating power between Sweden and the US, but also in a more general way in the early cold war. The limits of Britain's freedom of maneuvre in pursuing its own interests were evident in 1948-49, but this was in the end offset by Britain capacity to influence the overall position in its favour afterwards. Second, the British interest in the cold war in Scandinavia also bears witness to its character as a northern European power, closely involved in Scandinavian affairs not only as an external balancer but as an integral player. Third, the thesis highlights Britain's significance in influencing the external environment where Sweden's foreign 
policy operated, and thus facilitated Sweden's non-alignment in the cold war and the consolidation of the policy of neutrality without a fear of isolation from the West. Fourth, the dynamics between the different aspects of Britain's relations with Sweden, such as the relationship between trade and economic diplomacy, international institutional cooperation and political and strategic concerns arising from the cold war have been stressed both in the policy-making process and in its implementation. The fifth point of interest is in the central role that emerges for the different forms of informal cooperation both within and outside the institutional structure of Western cooperation in the postwar period. The 'public' institutional structure of Western cooperation, based primarily on organisations such as NATO and OEEC, was compounded with networks of cooperation on the 'private' sphere, facilitating informal exchanges with civilian and military authorities. This aspect was particularly significant in integrating neutrals within a wider group of Western nations, as defined by the ideological division of the cold war. 
Northern perspectives

Neutrality in the cold war

Britain and neutrality

Methods and sources

Historiographical context

The legacy of war

Bevin's 'grand design' and Stalin's intentions

A fresh start with Sweden $\quad 42$

The prospect of a Scandinavian bloc $\quad 55$

TRADE, ECONOMIC COOPERATION AND FOREIGN POLICY 1945-48 71

A double-edged sword

Sweden and Scandinavia in British trade and economy

Trade policy activated

Annual acrimony: The bilateral trade framework $\quad 85$

From Harvard to Paris $\quad 91$

AtLANTIC ALlianCE VS. SCANDINAVIAN UNITY 1948-1949 102

Bevin's Western Union and Scandinavia $\quad 103$

Stalin's advances and naval diplomacy 108

Western security and Scandinavian unity $\quad 115$

The Swedish attempt to grab the initiative $\quad 126$

A British compromise proposal 138

The way to the Atlantic Treaty 145

STRENGTHENING THE OEEC LINK: UNISCAN 1949-54 152

The establishment of Uniscan 153

A role for Uniscan 177

Mounting difficulties from the real economy 192

THE SCANDINAVIAN DEFENCE DILEMMA 1949-1951 203

The groundwork for a tacit understanding 205 
What form of association with the Atlantic pact?

Henderson's visit

Vougt's memorandum $\quad 245$

Cold feet in Sweden $\quad 252$

Loss of ministerial contact 263

An old policy for a new government 268

DEFINING SWEDEN'S POSITION IN WESTERN DEFENCE 1952-54 276

Changes in US policy 276

Channels opened 281

Bilateral and multilateral links $\quad 290$

Cooperation with limits 301

$\begin{array}{ll}\text { CONCLUSION } & 312\end{array}$

$\begin{array}{ll}\text { BIBLIOGRAPHY } & 326\end{array}$ 
'A glance at a map should be sufficient to bring home to everyone the fact that the importance of the Scandinavian countries in world affairs has lately increased to an extent which is almost startling. In a world divided, as at present, by an 'iron curtain' following roughly a line from the Arctic Ocean down the Baltic to the Adriatic, it is obvious that the Scandinavian peninsula no longer occupies a remote grand-stand in which its inhabitants can be passive and neutral spectators of any future conflict, but constitutes more than 1,200 miles of the front line dividing the forces of East and West.'

The Scandinavian States and Finland. A Political and Economic Survey (London: Royal Institute of International Affairs, 1951), vii. 


\section{INTRODUCTION}

This thesis is a study of the role Britain played in attempts to bind Sweden to the West between 1945 and 1954. The need to pull neutral Sweden into closer cooperation arose from a variety of British interests: strategy, economy and politics were all determining factors both in terms of motivation and policy goals. At the same time, Sweden's international orientation was perceived to be of considerable significance to the ways in which the cold war affected Scandinavia and the Nordic region as a whole. ${ }^{1}$

Four main questions will be addressed. What were British aims? How was policy formulated and executed? What was achieved? What was the significance of British policy to an understanding of the region in the early cold war? Answering these questions involves an assessment of Britain's interests in the north and how these were represented in policy-making as well as of Britain's role and influence in the early cold war international system. Policy towards Swedish neutrality throws light upon the general problem of the part Britain played during the first postwar years. Britain's significance as a player in the early cold war must also be assessed, as well as how far British thinking about the cold war in the Nordic region differed from the Americans'. This study requires understanding of how Britain behaved as an 'independent' actor in the cold war international system as it was manifested in northern Europe, and of British policy towards Swedish neutrality within a regional context that was later dubbed as the cold war 'Nordic balance'.'

1 'Scandinavia' is restricted to Norway, Denmark and Sweden. If Finland or Iceland is included, the term 'Nordic countries' or the 'Nordic region' is used. The term Nordic countries is an approximate translation of the the word 'Norden' in the Scandinavian languages and 'Pohjoismaat' in Finnish. The term 'northern Europe', geographically located north from the 540 latitude, is more difficult to define in geopolitical terms, but here refers to the Nordic countries together with the European countries with a considerable interest there, namely Great Britain, Germany, and the Soviet Union. The term 'Baltic' or the 'Baltic region' refers to the countries bordering the Baltic Sea.

${ }^{2}$ Arne Olav Brundtland, 'The Nordic Balance. Past and Present', Cooperation and Conflict, Vol. 1, No. 2 (1966), $30-63$. 


\section{Northern perspectives}

Britain, despite the exhaustion resulting from the war and the eclipse of its economic and military strength by the newly established superpowers, still had a global role. It had extensive military and economic commitments around the world and was politically centrally placed in the intersection of the Empire/Commonwealth, Europe and the Atlantic. As one of the victorious 'Big Three', Britain continued to have a voice amongst the leading world powers. Sweden, for its part, was for the British, the linchpin of any strategic or economic postwar arrangements in Scandinavia. Its overt international political role was more limited than its resources and geographical location might have suggested. With a population of only seven million, Sweden nevertheless had the fourth largest air force in the world and a sizeable navy, and was supported by a vigorous economy with worldwide trading links. In addition, the Swedes produced certain strategic goods, such as ball-bearings, specialized steels and high grade iron ore. ${ }^{1}$ Despite the close relations with the Norwegians and the Danes that had been established during the war, the British had to consider Sweden both in material and political terms as a regional leader whose foreign policy choices affected Britain's relations with other Scandinavian powers. But as had been proved in the war, Sweden was incapable and unwilling to act alone as a counterweight against determined great power intrusions.

\footnotetext{
1 On the Swedish armed forces, Carl-Fredrik Beijer \& Carl Björeman, Det försvarspolitiska vägvalet. Handlingsfrihet och nytänkande inför FB 92 (Kristianstad: Militärhistoriska Förlaget, 1991), 47 - 50. On Swedish postwar economy, international trade and trade policy: Lennart Jörberg \& Olle Krantz, 'Scandinavia', Carlo M. Cipolla (ed.), The Fontana Economic History of Europe. Vol. 6: 1914-1970, Contemporary Economies (London: Collins/Fontana, 1980); Lennart Petersson, Svensk utrikeshandel 1871-1980. En studie $i$ den intraindustriell handelns framväxt (Lund: Lund Economic Studies Number 30, 1984), 139 - 154; Birgit Karlsson, Handelspolitik eller politisk handling. Sveriges handel med öststaterna 1946-1952 (Göteborg: Institute of Economic History of Gothenburgh University, 1992), 30 - 33.
} 
As well as its other international preoccupations and commitments, Britain was in 1945 the only Western power with a tangible interest in Scandinavia. The Americans had given it lower priority during the war and the area had been primarily a British concern. ${ }^{1}$ In the immediate postwar period of 1945-47, the US let the British take the lead in Scandinavia. ${ }^{2}$ By 1945 , the Soviet Union had already established itself as the major Baltic power, and had expanded its sphere of influence in northern Europe westwards. The three Baltic states had become Soviet Socialist Republics and Finland, while retaining its independence, was closely tied to the Soviet sphere. German influence disappeared temporarily from the region in 1945 .

While Sweden's foreign policy choices were central to Britain's relations with its Scandinavian neighbours as a whole, the right approach to the problems posed by the cold war in Scandinavia also became an issue in Anglo-American relations. How the Western powers approached Sweden's policy of neutrality was illustrative of the ways in which neutrality became an established fact in the cold war international system. ${ }^{3}$ If it was accepted as a political reality, it was also adapted, adjusted and effectively contained in Europe. A central argument in this thesis is that the search for a modus vivendi with neutral Sweden started first in Britain, which later contributed to an environment in which both the US and the Soviet Union had to adjust their policies to the issue of cold war neutrality in Europe.

The basic tenet of British policy towards nonaligned Sweden was of inclusion and integration, not exclusion or isolation. Irrespective of Sweden's officially declared foreign policy, both Prime Minister Clement Attlee's and the Prime Minister Winston Churchill's

\footnotetext{
${ }^{1}$ Geir Lundestad, America, Scandinavia, and the Cold War 1945-1949 (New York: Columbia University Press, 1980), $43-44$.

2 Ibid., 52 - 53, 57 - 58, 63.

${ }^{3}$ On US attitudes towards cold war neutrality, see Jussi M. Hanhimäki, 'The First Line of Defence or a Springboard for Disintegration? European Neutrals in American Foreign and Security Policy, 1945-61', Diplomacy and Statecraft, Vol. 7, No. 2 (1996), 378 - 403.
} 
governments adopted a more benevolent attitude towards Sweden compared to the critical and rigid US line. That placed Britain in an important middle position between Sweden and its Scandinavian partners on the one hand, and the US on the other. This position could be used to foster closer Anglo-Swedish relations in the fora of international economic cooperation, in confidential military contacts and in attempts to align Sweden politically closer to Western viewpoints in East-West issues. For Sweden's attempts to keep the emerging blocs at arms length, British policy posed a different kind of challenge from that of the US. If the latter was manifested in open displeasure of Sweden's line, the British sought to achieve their goals with subtler and quieter means, in an atmosphere of close confidence, trust and consultation.

The starting point of the thesis is the transition from war to peace in 1945, which marks a natural break in Anglo-Swedish relations. The rapid disappearance of Germany as a power in northern Europe and as a counterweight to the Soviet Union; the general normalisation of relations between the countries; resumption of trade; the advent of a Labour government in Britain; and, most important, growing apprehensions of the intentions of the Soviet Union, were all essential characteristics of that year. The relationship between postwar reconstruction, international trade, and developments in East-West relations all increased Scandinavia's importance for Britain.

Year 1954, where the thesis ends, marks an end of the first phase in the cold war. ${ }^{1}$ West-German rearmament and the establishment of the Warsaw Pact signalled an end to one phase of the cold war, which was then followed by a fragile détente. The gradual decrease of Britain's significance in NATO's northern strategy and of its relative weight to the Scandinavian economies was combined with a more central American political role in Scandinavia. This was, however, as much due to changes in American as in British

\footnotetext{
${ }^{1}$ For general periodizations see for example the introduction to Charles S. Maier (ed.), The Cold War in Europe. Era of a Divided Continent (Princeton: Markus Wiener Publishers, 3rd ed., 1996), ix - xiv.
} 
postures. Due to changes in American policy towards Sweden, the need for a special mediating role for Britain was considerably reduced. The 'Nordic balance' was accepted as a political reality, with the Americans and the British sharing the basic policy objectives and the assumptions of how to manage it.

In parallel with these developments, from 1954 onwards the Soviet Union adopted a less antagonistic policy towards Scandinavia, which was manifested in 1955 in a public U-turn in its attitude towards neutrality. ${ }^{1}$ This also led to a lessening of the sense of tension and urgency for Western involvement. Nonetheless, as has been recently shown in a study of American policy towards Finland 1945-1956, this did not mean that the Soviet Union no longer posed a challenge to Western interests there, but that this challenge was now different. ${ }^{2}$ If the period before 1954 was marked by a need to consolidate Western interests in Scandinavia, the challenge after that would be how to maintain established positions.

While closely touching upon the question of Sweden's international orientation in the cold war, this thesis is primarily about British policy. The counterfactual question whether Sweden's policy of neutrality was compromised in the cold war cannot be satisfactorily answered, as that policy was never tested in war after 1945. In as much as this point is dealt with, the focus is on the British perception of the most likely course of events, if that policy was ever put to test.

1 Bo Petersson, The Soviet Union and Peacetime Neutrality in Europe. A Study of Soviet Political Language (Gothenburg: MH Publishing, 1990), 11 - 13.

2 Jussi M. Hanhimäki, Containing Coexistence, America, Russia, and the "Finnish Solution", 1945-1956 (Kent, Ohio: The Kent State University Press, 1997), 169 - 193. 
Neutrality in the cold war

This thesis is not a treatise in the international law of neutrality, nor is its primary aim to contribute to the conceptual work done by political scientists on the theoretical aspects of neutrality in international relations. But as historical works have often been accused of insufficient understanding of neutralitetsgrammatik, a number of observations on the legal and theoretical aspects would be in place. ${ }^{1}$

The concept of neutrality, as defined in international law, means non-participation in war between other states. It is thus essentially a concept for times of war, and there is no corresponding codification concerning neutrality in peace as is the case with the Hague Conventions of 1907 dealing with neutrality in war. ${ }^{2}$ However, a state can commit itself in time of peace to remain neutral in a future war. This 'permanent neutrality' can be made legally binding either in an international treaty or in national legislation. A permanently neutral state is bound by so called 'secondary obligations', which state that it should not take any actions that will compromise its wartime neutrality, i.e., enter a military alliance. Nonetheless, there is no obligation for a permanently neutral state to refrain from planning for different scenarios in which its neutrality might be infringed. ${ }^{3}$

The postwar official policy doctrine of Swedish neutrality evolved in stages and was defined unilaterally in government statements. Between 1945-48 Sweden first considered

1 Nils Andrén, 'On the Meaning and Uses of Neutrality', Cooperation and Conflict, Vol. 26, No. 2 (1991), 67 - 83; Sverker Ȧström, Ögonblick. Frän ett Halvsekel i UD-tjänst (Stockholm: Bonnier Alba 1992), 202 - 221. Ảström's term 'neutralitetsgrammatik' translates as 'Neutrality grammar' in English.

${ }^{2}$ For the relevant extracts of the Hague Conventions of 1907 see, Roderick Ogley, The Theory and Practice of Neutrality in the Twentieth Century, (London: Routledge \& Kegan Paul, 1970), 35 - 40.

${ }^{3}$ Om kriget kommit... Förberedelser för mottagande av militärt biständ 1949-1969. Betänkande av Neutralitetspolitikkommissionen. SOU 1994: 11 (Stockholm: Statens offentliga utredningar, 1994: 11), 49 - 50; Had there been a war... Preparations for the reception of military assistance 1949-1969. Report of the Commission on Neutrality Policy. Translation of SOU 1994: 11, (Stockholm: Statens offentliga utredningar 1994: 11), 49 - 50. 
collective security under the auspices of the United Nations Organisation rather than neutrality. Neutrality was then considered a reserve position if collective security failed. In February 1948 the Foreign Minister Östen Undén said that Swedish policy would not 'by any advance commitments' deprive itself 'of the possibility of keeping out of a new war'. Between April 1948 and January 1949 the Swedish government examined possibilities for a Scandinavian Defence Union (SDU), based on 'common neutrality'. After the failure of these negotiations, the Swedish government adopted the policy of 'non-participation in alliances in peacetime, aiming at neutrality in war'. This remained the basic formula of Sweden's cold war foreign policy and later became better know as the Swedish 'policy of neutrality' or its 'neutrality policy'. ${ }^{2}$ Even if Sweden was not a permanently neutral state in the sense that this applied to Switzerland, whose neutrality was guaranteed in the Concert of Vienna 1815 , its situation closely approximated that position. If not a de jure permanent neutral, it was nevertheless a de facto permanent neutral in the cold war. ${ }^{3}$ Thus, in this thesis the term neutrality means the peacetime foreign policies of countries like Sweden or Switzerland, i.e., de jure or de facto permanent neutrality.

The crux of cold war neutrality policy was its credibility. As Harto Hakovirta summed it up, credibility was its 'inherent and chronic problem since the emergence of the East-West conflict'. ${ }^{4}$ Would the powers with an interest in a peacetime neutral actually believe that it would remain neutral in a future war? And if they did, would they

\footnotetext{
' Quoted in Katarina Brodin \& Kjell Goldmann \& Christian Lange, 'The Policy of Neutrality: Official Doctrines of Finland and Sweden', Cooperation and Conflict, Vol. 3, No. 1 (1968), 18 51.

${ }^{2}$ Krister Wahlbäck, The Roots of Swedish Neutrality (Stockholm: Swedish Institute of International Affairs, 1986); Nils Andrén, 'Den mångtydiga neutraliteten', Internationella Studier, No. 2 (1991), 27 - 48.

${ }^{3}$ Rolf Lindholm, Sveriges neutralitet. Swedish Neutrality (Lund: Juridiska Föreningen i Lund, 1987), 38.

${ }^{4}$ Harto Hakovirta, East-West Conflict and European Neutrality (Oxford: Clarendon Press, 1988), $52-53$.
} 
respect the neutral's rights? These questions depended not on international law, which merely provided 'the perceptual framework and system of mutual expectations of each of the actors involved, regarding the essence of neutrality', but on the political judgment of the foreign powers in question. ${ }^{1}$ That judgement took place against the backdrop of the foreign power's own self-interest and that power's judgment of the neutral's interest. ${ }^{2}$

The problem of credibility arose in part because of the nature of the cold war itself. This 'long peace', was a peace in terms of international law, but in political terms it was a halfway-house to war. ${ }^{3}$ In addition, all-encompassing superpower rivalry with a rapid expansion of traditional diplomacy into postwar 'total diplomacy', reflecting the wider functions of state, international institutional cooperation, and the general increased interdependence between states, defined the scope of neutrality in a new way. ${ }^{4}$ As Jürg Martin Gabriel has stressed in his study of American attitudes towards neutrality, during the cold war the relevance of international law to neutrality declined while political connsiderations gained more weight. ${ }^{5}$ Furthermore, issues that previously had little bearing in traditional foreign policy terms, such as trade and economic cooperation, became more important in defining a state's international position. Hakovirta has stressed how the pre-Second World War neutrals could operate in 'a system characterized by different variants of flexible multipolarity and social-ideological homogeneity', where

${ }^{1}$ Efraim Karsh, Neutrality and Small States (London: Routledge, 1988), 6.

2 Krister Wahlbäck, 'Aderton missförstånd om svensk säkerhetspolitik', Internationella Studier, No. 3, hösten 1995, 37 - 80.

${ }^{3}$ John Gaddis's term, later described 'not so much wrong as shortsighted'. John Gaddis, The Long Peace. Inquiries Into the History of the Cold War (Oxford: Oxford University Press, 1987); Gaddis, We Now Know. Rethinking Cold War History (Oxford: Clarendon Press, 1997), 279 280. This aspect of the cold war from the neutrals' viewpoint is discussed in Dietrich Schindler, 'Aspects contemporains de la neutralité', Academie de Droit International. Recueil des Cours, 1967 Vol. II, Tome 121 de la collection (Leyden: A. W. Sijthoff, 1969), 239 - 40, 295 - 9.

${ }^{4}$ A term used in Keith Hamilton \& Richard Langhorne, The Practice of Diplomacy. Its Evolution, Theory and Administration (London: Routledge, 1995), 183 - 227.

5 Jürg Martin Gabriel, The American Conception of Neutrality after 1941 (London: Macmillan, 1988), 3, $212-213,217-218$. 
their ideological orientation did not have any major relevance for their neutrality in international disputes. ${ }^{1}$ In contrast, from the Second World War onwards the new system in which the neutrals had to operate was a system in which 'all aspects of the external relations and even domestic developments of nations, the bloc members and all others alike, have tended to acquire meaning as indications of their positions in relation to the master conflict between the East and the West, and this has been especially true during time of highest tension' ${ }^{2}$

It can be argued that what was previously considered as legitimate freedom of manoeuvre for neutral states in time of peace, was more restricted in the cold war zerosum game of rigidly fixed alliances and spheres of interest. The neutrals had to consider their actions within narrower margins than had previously been the case in times of peace. These narrower margins were acknowledged by the Swedish government, although the exact boundaries were never clear. Despite the multifaceted character of the cold war, neutrality policy was nevertheless constructed essentially in military terms. This, while posing a challenge to British policymakers, also provided a window of opportunity to influence Swedish policy into a more westerly direction, if seized rightly.

\section{Britain and neutrality}

In a classic textbook, Joseph Frankel described the pragmatism of British foreign policy as being derived from the 'pronounced tendency of the British policy-makers to eschew ideology and to concentrate upon the concrete details of their environment' ${ }^{3}$ This

Hakovirta, East-West Conflict and European Neutrality, 51 - 52.

2 Ibid., 52.

${ }^{3}$ Joseph Frankel, British Foreign Policy, 1945-1973 (London: RIIA and Oxford University Press, 1975), 112. 
pragmatism has helped policy-makers to 'preserve the maximum flexibility possible, to avoid excesses due to ideological commitments, to concentrate diplomatic efforts upon specific interests, to recognize hard facts'. ${ }^{1}$ Problems arise, when 'the cult of the implicit', a tendency to avoid harsh and precise formulations and the avoidance of planning ahead in general or theoretical terms, makes fundamental choices of priorities difficult. It also 'encourages a divorce between thinking on general lines and political action', and hence makes it in analytical terms difficult to deduct general modes of action from specific cases, even if basic foreign policy priorities and goals have been clear. ${ }^{2}$

This pragmatic tradition in part explains why it is difficult to see any coherent or systematic way in which Britain has responded to neutrality in international relations. Patrick Salmon has attempted to derive some general 'rules of conduct' from Britain's responses to neutrality, mainly in the two world wars. ${ }^{3}$ These fall in seven cases: 1) do not make a formal commitment to respect neutrality if there is any possibility that you may wish to violate it; 2) discourage neutral cooperation; 3) exploit British maritime strength to exert pressure on neutrals; 4) appease neutrals; 5) find allies within neutral countries; 6) do not allow ideology to influence policy; and 7) as a last resort, consider forcible action against a neutral state. Already from these, in part overlapping, in part alternative headings it can be seen that Britain's responses have varied greatly.

A longer historical perspective confirms the notion of the essential pragmatism of British attitudes towards neutrality. Neutrality has had little appeal for Britain itself, at least in the 20th century, but if a basic trend can be discerned, it points towards a certain benevolence and respect of neutrals' rights, and a willingness to settle for compromises

${ }^{1}$ Ibid., 113.

${ }^{2}$ Ibid., 114 - 115.

${ }^{3}$ Patrick Salmon, 'British Attitudes towards Neutrality in the Twentieth Century', Jukka Nevakivi (ed.), Neutrality in History. La neutralité dans l'historie (Helsinki: Finnish Historical Society, 1993), $117-132$. 
with otherwise like-minded states. ${ }^{1}$ A case-by-case approach towards neutrality was characteristic of Britain during its period as an international hegemon in the 19th century. The liberal spirit represented in the Hague Conventions of 1907, giving neutrals the freedom of carrying on their peacetime trade 'courant normal' with belligerents was characteristic of Britain's attitude at the time. ${ }^{2}$ Also after 1914 the practical treatment of neutrals was more circumspect than the combatative rhetoric of Winston Churchill might have suggested. ${ }^{3}$ Moral scruples about applying ruthless methods towards smaller neutrals, seem to have been genuine. Belgian neutrality before 1940 was approached pragmatically, and the British went to great lengths to accomodate Belgium's national sensitivities before the German invasion. ${ }^{4}$ According to Salmon, '[f]or much of the nineteenth century, in contrast to the twentieth, official rhetoric placed Britain and humanity together on the side of neutrality'. ${ }^{5}$ When Germany accused Britain of having planned an invasion to neutral Scandinavia in May 1940 the Permanent Under-Secretary Sir Alexander Cadogan minuted:

We may have had 100 plans for intervention in Scandinavia. The point is that rightly or wrongly - unlike the Germans - we drop our plans if they are distasteful to the wretched little neutral country concerned. That may be foolish and oldfashioned, but it is fairly respectable. ${ }^{6}$

${ }^{1}$ Gabriel, The American Conception of Neutrality after 1941, 125. A rare case for British cold war neutrality was put forward in Peter Johnson, Neutrality. A Policy for Britain (London: Temple Smith, 1985).

${ }_{2}$ Gabriel, The American Conception of Neutrality after 1941, 214. This benevolent pragmatism in Britain's attitudes to neutrality in the late 19th and early 20th centuries has also been pointed out by Salmon, but was hardly the case earlier.

${ }^{3}$ Salmon,'British Attitudes towards Neutrality in the Twentieth Century', 117 - 132.

${ }^{4}$ Marian Kent, 'British Foreign Policy and Belgian Neutrality 1936-1940', Nevakivi, Neutrality in History, $173-185$.

s Salmon,'British Attitudes towards Neutrality in the Twentieth Century', 117 - 132.

${ }^{6}$ Cadogan minute 2 May 1940, quoted in Salmon, 'British Attitudes towards Neutrality in the Twentieth Century', 130. 
However, the unavoidable conclusion from the assessment of self-interest and idealism in British attitudes towards neutrality is, as Salmon says, that in a longer historical perspective the choice to act with moderation to neutrals has probably been 'due to weakness as much as conviction'. ${ }^{1}$ Even if Britain might have deemed it necessary to violate neutral rights, it did not always have the means to do so. Virtue was easily made out of necessity, and this became more relevant after the Second World War.

Another important characteristic in British attitudes towards neutrality, as contrasted with the US, was that if the British in the heyday of their power restricted neutral rights, they did so for imperial reasons. The Americans in contrast, after they had abandoned their own tradition of neutrality in 1941 , did so for universalist ones. ${ }^{2}$ British and US values were not identical in this sense, and this had special significance in the ideologically charged atmosphere of the cold war. The legacy of pragmatism and realism in British attitudes towards neutrality provided a relatively flexible framework in which it could be interpreted. How well Britain's policy towards Swedish neutrality in the early cold war fits in this tradition will be assessed in the chapters that follow.

\section{Methods and sources}

Although international history research is increasingly being conducted with a multiarchival emphasis, writing a genuinely multiarchival international history has been beyond the scope and aims of this study. ${ }^{3}$ The main methodological point of departure has been to analyse the topic beyond the rather narrow remit of traditional diplomatic

\footnotetext{
${ }^{1}$ Salmon, 'British Attitudes towards Neutrality in the Twentieth Century', 117 - 132.

${ }^{2}$ Gabriel, The American Conception of Neutrality after 1941, 219.

${ }^{3}$ For example, Donald Cameron Watt, How War Came: The Immediate Origins of the Second World War, 1938-1939 (London: William Heinemann, 1989).
} 
history. In this respect the challenge for what has been called 'New Diplomatic History' has been interpreted as being primarily twofold. ${ }^{1}$ Pressures have arisen from two main directions: from the discipline of history itself and from the social sciences. On the one hand, following developments in economic and social history, there is an increased need for a greater sensitivity to the complex interplay of the history of slow structural change in the long and medium term and the history of political events in the short term. On the other hand, developments especially in the study of international relations has led to an increased interest in issues such as international institutional and multilateral cooperation, international economic policy, and the influence of also non-state actors in international relations. The foreign policy process itself has become a central point of interest for historians as well, although in most of these areas the level of methodological and conceptual sophistication has yet to reach that of social and political scientists. All this has led to a reassessment of the concept of diplomatic history itself, in order to facilitate the analysis of the complex and diverse character of international affairs in the later 20th century.

While the treatment of primary material is here largely based on traditional qualitative methods of international history, the thesis attempts to construct a fuller picture of the structural basis of Britain's relations with Sweden and of the interests represented in the making and implementation of foreign policy. Interests arising from military-strategic and economic conditions, bureaucratic and organisational interests and perceptions of national interests and threats to them are all considered part and parcel of the larger

\footnotetext{
${ }^{1}$ This term has recently been used by Elisabeth Cobbs Hoffman, 'Diplomatic History and the Meaning of Life: Toward a Global American History', Diplomatic History, Vol. 21, No. 4 (1997), 499 - 518. The main forum for the reassessment of the purpose and methodology of diplomatic history has over the past decade been the American journal Diplomatic History. See also the articles on the relationship of international relations theory and historical analysis in Ngaire Woods (ed.), Explaining International Relations Since 1945 (Oxford: Oxford University Press, 1996).
} 
interdependent whole of foreign policy making. At the same time, it is important to see where and how in the British governmental machine was Scandinavian policy made. All this having been said, the principal focus of this work is not on what happened within the British foreign policy process or on the domestic arena, but on Britain's actions internationally. The former has been studied as far as it has been necessary in order to understand the latter and remains one of the secondary themes.

The research is largely based on primary archival material of the British Cabinet, Foreign Office (FO), Ministry of Defence, service departments, Treasury and Board of Trade, which are in the Public Record Office (PRO), Kew, London. A great majority of the material was made available under the 30-year rule, and in the case of the Ministry of Defence, from 1988 onwards. In 1994-96 new material concerning defence and sensitive political issues was released as a result of the Open Government Initiative and the work of the Swedish Neutrality Policy Commission. This new material has been instrumental to an understanding of Sweden in British policy between 1949-54. It includes information about exchanges between British and Swedish service authorities about possible wartime cooperation; talks on the political and official level; the relationship of North Atlantic Treaty Organisation (NATO) machinery and the British service departments; and internal discussions and policymaking towards Swedish neutrality and Scandinavian defence problems in general. ${ }^{1}$ Without this material it would

\footnotetext{
${ }^{1}$ Despite the fact that archival material is now available on Anglo-Swedish defence relations, problems with evidence still remain, and will do so in the future as well. Most methodological problems are due to the fact that a good deal of what went on between Western and Swedish military authorities was done verbally without leaving written documents behind. A case in point are the plans that were made public on 22 March 1998 by retired Swedish generals. In case of a Soviet attack, the Swedish naval commander, accompanied by staff officers, would have immediately moved to Britain, where facilities were prepared for the establishment of a Swedish command centre. These plans were operational until mid-1980s, but were based entirely on verbal communication and agreements, and were not revealed outside the highest military leadership in Sweden. Mikael Holmström, 'Marinchef i exil skulle försvara riket', Svenska Dagbladet (SvD). 22.3.1998.
} 
have been impossible to reconstruct a detailed picture of Anglo-Swedish relations. The only notable omissions remaining in the British material concern intelligence cooperation, which other primary and secondary sources indicate to have been extensive in the 1950s between Britain and Sweden. ${ }^{1}$ Most of this material is held under 50 or 100 year restrictions.

Previous research has largely concentrated on the FO Northern Department documentation on Scandinavia. ${ }^{2}$ This thesis has also used files from the Ministry of Defence and the service departments, the Treasury and the Board of Trade. The archives of the last two have until now, been very little used by scholars, despite the fact that they have been open according to the 30-year rule. The full minutes and memoranda of the Chiefs of Staff Committee (COS) have been available with the transfer of the original bound volumes to the PRO in 1995-96. The economic departments had a considerable interest in Sweden and Scandinavia from a commercial but also from an international economic policy point of view. In questions closely linked to the cold war, such as the trade of strategic goods, raw materials and arms exports, the Ministry of Supply was also involved. The close attachment of the Scandinavian countries to the Sterling area also made the Bank of England, with its close relations with the Scandinavian central banks, an interested party in Britain's handling of its relations with Sweden. The Cabinet committees mainly involved in policy towards Sweden were the Defence Committee, Economic Relations Committee, Economic Policy Committee and the Trade and Payments Sub-Committee. Policy towards Sweden or the other Scandinavian countries was only rarely brought to full Cabinet. The fishing disputes with Iceland in the 1950s,

\footnotetext{
1 Tom Bower, The Red Web. MI6 and the KGB Master Coup (London: Mandarin, 1993); Mert Kubu, 'Svensk militär grundlurades', Dagens Nyheter (DN), 2.1.1998.

2 There is one exception to the rule: Bengt Nilson, 'No Coal without Iron Ore. AngloSwedish trade relations in the shadow of the Korean War', Scandinavian Journal of History (SJH), Vol. 16, No. 1 (1991), 45 - 72.
} 
for example, consumed Cabinet time excessively and far more than Scandinavian issues as a whole. The time spent in the full Cabinet, however, is not necessarily an accurate indication of the intrinsic importance of the issues at hand, but can rather be a symptom of their intractability or their controversiality within the Cabinet. ${ }^{1}$ In the Houses of Parliament, Scandinavia appeared intermittently in foreign policy debates, especially in 1947-49, and Hansard has therefore been consulted.

Official primary material has been augmented by examination of private papers, newspapers and periodicals, contemporary literature and other published material. Of private papers the most important have been the papers of the ambassadors Sir Victor Mallet and Sir Roger Stevens lodged in Churchill College, Cambridge. Ernest Bevin's, Clement Attlee's and Sir Stafford Cripps's private papers have also been used, although the official archives and Bevin's and Anthony Eden's private office papers in the PRO contain the great majority of information relevant to this thesis.

In Sweden, the process of archival openings for the postwar period for researchers began in the early 1990s. The work of the Neutrality Policy Commission 1992-94 resulted in a further acceleration of this process. There is now a general 40 -year rule on classified material, under which the papers of all relevant civilian and military authorities have been available for this thesis. Private papers are available, although there still are some restrictions here. The most notable omission is the diaries of the Prime Minister Tage Erlander, which have been used by his biographer and the Neutrality Policy Commission, but to which other scholars do not yet have access. Information from this source has been derived from these published works. ${ }^{2}$

The Swedish Foreign Ministry archives, the papers of the Foreign Policy Committee (Utrikesnämnd) and the archives of the Swedish military authorities have been used. Due

\footnotetext{
' Peter Hennessy, Cabinet (Oxford: Basil Blackwell, 1986), 185 - 186.

${ }^{2}$ Had there been a war...; Olof Ruin, Tage Erlander. Serving the Welfare State 1946-1969 (Pittsburgh: University of Pittsburgh Press, 1990).
} 
to the central position of the Foreign Minister Östen Undén and his ministry in the Swedish foreign policy process at the time, the archives of the Foreign Ministry have received most attention. However, this does not mean that the monolithic appearance of Sweden's handling of its external relations has to be taken at face value, especially during the early cold war years. The official and private material of military authorities has provided additional light on the extent to which other actors were players on the field of Sweden's relations with the Western powers. The detailed private diaries of the generals Helge Jung and Nils Swedlund, supreme commanders 1944-51 and 1951-61 respectively, have been especially helpful. In assessing wider opinion in the Swedish political elite on foreign policy issues, the papers of the Foreign Policy Committee have also been useful.

Having said this, it has to be stressed that research in Sweden has not been conducted to write the history of Swedish foreign policy. Two main motivations stand out. The first lies in the way the Swedish documentation provides additional information on discussions with the British and a way of assessing the reliability and accurateness of British accounts. As a rule, Swedish minutes of discussions with the British are longer and more detailed, and in a number of cases the only surviving source is a Swedish Foreign Ministry document. This applies especially to Bevin's discussions with the Swedes, but also to Eden, both of whom - or their private secretaries - were less detailed in minuting conversations than their interlocutors. The second motivation has been in the need to assess the implications and impact of Britain's policy in Sweden. The only valid sources of the perception in Sweden of Britain's policy are, obviously, the Swedish ones, and as perception perhaps influences reality as much as reality influences perception, this has to be assessed from the point of view of the significance of Britain in the area.

Unpublished American documents from various presidential libraries and the National Archive in Washington have been consulted in Stockholm, where an important reprographic collection is housed as a part of the Neutrality Policy Commission's 
Archive in the Central Archive of the Swedish Government. Otherwise the Foreign Relations of the United States series has provided additional documentation. Of the other Nordic powers, Finnish documentation has been extensively consulted. This has been used to bring additional perspectives to the main substance from a deeply interested, but detached party. The recently opened Finnish archives have been little used by other scholars of the cold war in Scandinavia.

\section{Historiographical context}

The historiography concerning the cold war has mainly concentrated on US foreign policy, most of which has also been written in the US. During the 1980s more attention was paid to other actors, such as Britain, France and West Germany. In the 1990s, after the collapse of the Soviet Union and the opening of archives in the previous Eastern bloc, interest has been shifting to the study of Soviet policy and the states in Eastern Europe. ${ }^{1}$ International and multilingual perspectives to cold war history have in general won more

\footnotetext{
${ }^{1}$ Main findings have been published in the Cold War International History Project Bulletin (Washington DC: Woodrow Wilson International Center for Scholars, 1992-). First syntheses of Soviet policy are Vladislav Zubok \& Constantine Pleshakov, Inside the Kremlin's Cold War. From Stalin to Khrushchev (Cambridge, Mass.: Harvard University Press, 1996) and David Holloway, Stalin and the Bomb. The Soviet Union and Atomic Energy 1939-1956 (New Haven: Yale University Press, 1994). A major new, 'neo-traditionalist' interpretation is found in Gaddis, We Now Know. On Soviet policy towards Scandinavia see, Sune Jungar \& Bent Jensen (eds.), Sovjetunionen och Norden - konflikt, kontakt, influenser (Helsinki: Finnish Historical Society, 1997); Maxim Korobochkin, 'Soviet Policy Toward Finland and Norway, 1947-1949, SJH, Vol. 20, No. 3 (1995), 185 - 207; Bo Petersson, Med Moskvas Ögon. Bedömningar av svensk utrikespolitik under Stalin och Chrusjtjov (Smedjebacken: Arena, 1994); Jukka Nevakivi, 'Kekkonen, the Soviet Union and Scandinavia - Aspects of Policy in the Years 1948-1965', SJH, Vol. 22, No. 2 (1997), 65 - 81. On Finland see the articles in Jukka Nevakivi, Finnish-Soviet relations 1944-48 (Helsinki: Department of Political History, University of Helsinki, 1994); and Jukka Nevakivi, 'A Decisive Armistice 1944-47: Why Was Finland Not Sovietized?', SJH, Vol. 19, No. 2 (1994), 91 - 115.
} 
ground, also in US diplomatic history.

It has been customary to divide Western literature about the cold war in three main categories: traditionalist, revisionist and postrevisionist. ${ }^{1}$ These have followed broadly the main currents in the developments of American foreign policy debates. The first, traditionalist or orthodox writing, emerged soon after the cold war began. The central theme was to lay blame on the Soviet Union, its ideological orientation and its aggressive policies. ${ }^{2}$ The Vietnam War in particular led some scholars in the 1960 s to challenge this view. The revisionist line turned previous interpretations upside down and found its main criticism in US policies, especially in its desire to impose a global economic and trading system, which would serve its expansive purposes. ${ }^{3}$ In both traditionalist and revisionist writing, blame, guilt and responsibility for the conflict were important considerations. During the détente of the 1970s, again reflecting the international and domestic political climate, a more balanced view emerged about the origins of the cold war. Postrevisionist writing emphasised the complexity of the international situation and conflicting national interests of the main players. ${ }^{4}$

At the same time, the opening of the British archives for the postwar period, encouraged a multipolar view of cold war origins to develop. Following the pioneering work by Victor Rothwell and Alan Bullock, the thesis about Britain's importance in the immediate postwar period in confronting the Soviet Union won more ground during the

\footnotetext{
${ }^{1}$ John Lewis Gaddis, 'The Emerging Post-Revisionist Thesis on the Origins of the Cold War', Diplomatic History, Vol. 7, No.3 (1983), 171 - 190.

${ }^{2}$ For example, Herbert Feis, Churchill, Roosevelt, Stalin. The War They Waged and the Peace They Sought (Princeton: Princeton University Press, 1957); Herbert Feis, From Trust to Terror: The Onset of the Cold War, 1945-1950 (New York: Norton, 1970); Charles E. Bohlen, Witness to History 1929-1969 (New York: Norton, 1973).

${ }^{3}$ For example, William Appleman Williams, The Tragedy of American Diplomacy (New York: Dell, 1959); Joyce and Gabriel Kolko, The Limits of Power: The World and United States Foreign Policy 1945 - 1954 (New York: Harper \& Row, 1972).

${ }^{4}$ For example John Lewis Gaddis, The United States and the Origins of the Cold War 19411947 (New York: Columbia University Press, 1972); Daniel Yergin, Shattered Peace: The Origins of the Cold War and the National Security State (Boston: Houghton Mifflin, 1977).
} 
1980s. ${ }^{1}$ Rothwell's emphasis on British concerns over a future threat from Germany was reassessed by other writers, who stressed the anti-Soviet orientation of British strategic planning and foreign policy. ${ }^{2}$ Bullock's identification of Bevin with British foreign policymaking has also been criticised, especially for the first postwar years, when the influence of the FO officials has seen to been higher. ${ }^{3}$ However, by the mid-1980s a consensus had been reached on both sides of the Atlantic which placed Britain as a third player with the US and the Soviet Union during the postwar years.

In a seminal essay, Donald Cameron Watt suggested in 1978 that the main thrust of research in British postwar foreign policy should not follow the American example of concentrating on guilt and responsibility, but to enhance general understanding of the conflict. ${ }^{4}$ Similar developments as in the American case, were nevertheless soon discernible. By the later 1980s, a stronger interpretation emerged on the British role in the origins of the cold war. While research into the Soviet archives increasingly identified the cold war with Stalin's personality and the fundamental assumptions behind Soviet foreign policy, in Britain more responsibility was put on Bevin, his officials and on the

1 Victor Rothwell, Britain and the Cold War 1941-1947 (London: Jonathan Cape, 1982); Alan Bullock, Ernest Bevin. Foreign Secretary 1945-1951 (London: William Heinemann, 1983); Robert Hathaway, Ambiguous Partnership: Britain and America 1944-1947(New York: Columbia University Press, 1981); Terry H. Anderson, The United States, Great Britain, and the Cold War, 1944-1947 (Columbia: University of Missouri Press, 1981); Elisabeth Barker, The British Between the Superpowers 1945-1950 (London: Macmillan, 1983); Ritchie Ovendale, The Englishspeaking Alliance: Britain, and the United States, the Dominions and the Cold War, 1945-1951 (London: Allen \& Unwin, 1985); Robin Edmonds, Setting the Mould: The United States and Britain 1945-1950 (Oxford: Clarendon Press, 1986); William Roger Louis, The British Empire in the Middle East 1945-1951. Arab Nationalism, the United States, and Postwar Imperialism (Oxford: Oxford University Press, 1984).

2 Julian Lewis, Changing Direction. British Military Planning for Post-War Strategic Defence, 1942-47 (London: Sherwood, 1988); Peter J. Taylor, Britain and the Cold War: 1945 as Geopolitical Transition (London: Pinter, 1990).

${ }^{3}$ Raymond Smith, 'Ernest Bevin, British Officials and British Soviet Policy, 1945-47', Anne Deighton (ed.), Britain and the First Cold War (London: Macmillan, 1990), 32 - 52.

${ }^{4}$ Donald Cameron Watt, 'Rethinking the Cold War: A letter to a British Historian', Political Quarterly, Vol. 49, No. 4 (1978), 446 - 456. 
imperial dimension in British foreign policy making. ${ }^{1}$ The strongest arguments highlighted Britain's role in drawing the US into the conflict with the Soviet Union, in the division of Germany and in arousing Soviet suspicions by continuing an overstretched imperial defence and foreign policy on a global scale. According to this interpretation, especially during 1945-47, Britain's perception of a hostile and expansive Soviet Union led it to pursue those kinds of containment policies more famously associated with the US. This Anglo-Soviet cold war was then followed by the global cold war. Henry Butterfield Ryan has argued that without the drastic reduction in British power and the simultaneous need to use the US as a counterweight to the Soviet union, the cold war might never have happened. ${ }^{2}$ The 'catalytic theory of British responsibility' is, however, found in its purest form in John Kent's argument:

In 1945 Soviet-American cooperation had to be avoided to preserve British imperial interests and to ensure British weakness could eventually be overcome; ... By 1949, because of the Cold War, attempts to preserve power, status and links with the Empire could be justified in terms of Western interests. Thus the Cold War was partly caused by and then helped to maintain an imperial strategy that avoided acceptance of the post-World War shift in the global balance of power and a radical reassessment of the costs and desirability of maintaining a global role. ${ }^{3}$

The British had a double responsibility; first to instigate a conflict with the Soviet Union,

' John Lewis Gaddis, 'The Tragedy of Cold War History', Diplomatic History, Vol. 17, No. 1 (1993), 1 - 16; Fraser J. Harbutt, The Iron Curtain: Churchill, America, and the Origins of the Cold War (New York: Oxford University Press, 1986); Henry Butterfield Ryan, The Vision of Anglo-America. The US-UK Alliance and the Emerging Cold War, 1943-1946 (Cambridge: Cambridge University Press, 1987); Anne Deighton, The Impossible Peace: Britain the Division of Germany and the Origins of the Cold War (Oxford: Oxford University Press, 1990); Deighton, Britain and the First Cold War; John Kent, British Imperial Strategy and the Origins of the Cold War 1944-49 (Leicester: Leicester University Press, 1993).

${ }^{2}$ Ryan, The Vision of Anglo-America, 6.

${ }^{3}$ Kent, British Imperial Strategy and the Origins of the Cold War 1944-49, 217. The 'catalytic theory'-term is by Maier, The Cold War in Europe, 5. 
and then in maintaining it. Unlike the consensus over Britain's position as a third player in the early cold war, the arguments that rest this responsibility on it have not won equal approval. Watt has pointed out that without research into Soviet policy-making and perceptions, the effect of Britain's actions will remain unclear. ${ }^{1}$ By 1998 , no evidence from the East has emerged to support the strongest claims. Geoffrey Warner has criticised its Anglo-centricity and argued that Bevin was initially also suspicious of the US as well as the Soviet Union. According to Warner, it was only relatively late in 1947 when Bevin gave up hope of détente with Stalin. Furthemore, the Americans hardly needed any help in arousing to the communist threat and from 1947 onwards the US would have moved to consolidate Western Europe with or without Bevin. ${ }^{2}$

A separate, but related debate on Britain's postwar international role has concentrated on British policy towards postwar Western European cooperation and the refusal in the 1950s of Britain to join the continental powers in the emerging institutional structure of economic cooperation, such as the European Coal and Steel Community 1950-52 or the European Economic Community 1955-57. Bevin's role in trying to establish a viable 'third force' in a partnership with the Commonwealth and Britain's Western European neighbours as a future power base for its global role has been examined by various authors. ${ }^{3}$ They have stressed the Labour government's attempts to contribute positively

\footnotetext{
${ }^{1}$ D. C. Watt, review of Deighton, Britain and the First Cold War, International Affairs, Vol. 67, No. 1 (1991), 163 - 165.

${ }^{2}$ Geoffrey Warner, 'The Study of Cold War Origins', Diplomacy and Statecraft, Vol. 1, No. 3 (1990), 13 - 26; Geoffrey Warner, 'Ernest Bevin and British Foreign Policy, 1945-1951', Gordon A. Craig \& Francis L. Loewenheim (eds.), The Diplomats 1939-1979 (Princeton: Princeton University Press, 1994), 127.

${ }^{3}$ John W. Young, Britain and European Unity, 1945-1992 (London: Macmillan, 1993), 6 27; Sean Greenwood, Britain and European Cooperation Since 1945 (Oxford: Blackwell, 1992), 7 - 17; Sean Greenwood, 'The Third Force in the Late 1940s', Brian Brivati \& Harriet Jones (eds.), From Reconstruction to Integration: Britain and Europe since 1945 (Leicester: Leicester University Press, 1993), 59 - 70; Geoffrey Warner, 'The Labour Governments and the Unity of Western Europe, 1945-51, Ritchie Ovendale (ed.), The Foreign Policy of the British Labour Governments 1945-1951 (Leicester: Leicester University Press, 1984), 61 - 82.
} 
to Western unity in the 1940 s. The subsequent failure to 'abdicate the leadership in Europe' by refusing to participate in the Schuman Plan of 1950 and the decision not to join the Rome Treaties in 1956 have served as focal points in this debate. ${ }^{1}$ More recently the continuing failure in 1961-63 of Britain to catch up with 'Europe' has received increasing scholarly attention. ${ }^{2}$ The 'Britain and the cold war' debate has in the $1990 \mathrm{~s}$ been overshadowed by the 'Britain and Europe' debate, reflecting probably not only shifts in scholarly interests but in contemporary political debates. The relevance of the latter debate to this thesis is in the way changes in British foreign policy priorities have been assessed. As both the Atlantic and Commonwealth circles continued to be paramount in British policy priorities until the 1960s, Britain's policy towards Scandinavian participation in European cooperation emerges as a distinctive side in Britain's role as a postwar European power.

There is comparatively little written about Britain's relations with the Nordic countries after the Second World War. ${ }^{3}$ What literature exists has predominantly concentrated on cold war security policy in 1947-49 and is written mostly from a Nordic or US viewpoint, with British policy only considered as a secondary concern. ${ }^{4} \mathrm{~A}$ number of

${ }^{1}$ Edmund Dell, The Schuman Plan and the British Abdication of Leadership in Europe (Oxford: Oxford University Press, 1995); Wolfram Kaiser, Using Europe, Abusing Europeans. Britain and European Integration, 1945-63 (London: Macmillan, 1996).

${ }^{2}$ N. Piers Ludlow, Dealing with Britain. The Six and the First UK Application to the EEC (Cambridge: Cambridge University Press, 1997).

${ }^{3}$ An introduction to the essential problematic, and a discussion of the differences in pre- and postwar British policy towards Scandinavia is found in Patrick Salmon, 'Great Britain and Northern Europe from the Second World War to the Cold War', R. Bohn \& Jürgen Elvert (eds.), Kriegsende im Norden. Vom Heißen zum kalten Krieg (Stuttgart: Franz Steiner Verlag, 1995), $197-215$.

${ }^{4}$ A good introduction to the general Scandinavian perspective is Helge Pharo, 'Scandinavia', David Reynolds (ed.), The Origins of the Cold War in Europe. International Perspectives (New Haven: Yale University Press, 1994), 194 - 222. Other central works in English are: Lundestad, America, Scandinavia and the Cold War; Rolf Tamnes, The United States and the Cold War in the High North (Aldershot: Dartmouth, 1991); Magne Skodvin, Nordic or North Atlantic Alliance? The Postwar Scandinavian Security Debate (Oslo: Institute for Defence Studies, 1990); Kersti Blidberg, Just Good Friends. Nordic Social Democracy and Security Policy 1945-50 (Oslo: 
important works are not available in English. ${ }^{1}$ The road to NATO and the failure of the Scandinavian Defence Union has received most attention. In Scandinavia, the scholarship on the postwar period has been the thinnest in Sweden, whereas in Norway and Finland different aspects of contemporary international history have been more thoroughly researched. ${ }^{2}$ Until lately, restrictive archival practice hindered research in Denmark. ${ }^{3}$ British foreign policy towards Finland has been studied by several Finnish scholars, but here again, the primary concern has been Finland's international and domestic situation. ${ }^{4}$

The first works in which British policy towards Scandinavia was assessed were Magne Skodvin's Norden eller NATO? from 1971 and Nils Morten Udgaard's dissertation Great

Institute for Defence Studies, 1987). Jussi M. Hanhimäki, Containing Coexistence. Also the issue of the SJH, Vol. 10, No. 3 (1985) is still a useful collection of articles on the different Nordic countries in the cold war.

1 Helge Pharo \& Knut Einar Eriksen, Kald Krig og internasjonalisering, Norsk utenrikspolitikks historie (Oslo: Cappelen, 1997); Poul Villaume, Allieret med forbehold. Danmark, NATO og den kolde krig. En studie $i$ dansk sikkerhedspolitik,(Copenhagen: Eirene 1995); Carsten Due-Nielsen \& Johan Peter Noack \& Nikolaj Petersen, (eds.), Danmark, Norden og NATO, 1948-1962 (Copenhagen: Jurist- og Økonomforbundets Forlag, 1991). Except Had there been war... practically all Swedish scholarship relevant to the topic that has been published in the 1990s is not available in English.

${ }^{2}$ For an overview of the research in Norway, see Knut E. Eriksen \& Helge Pharo, Norsk sikkerhetspolitikk som etterkrigshistorisk forskningsfelt. Etterkrigshistorisk Register, nr. 21, April 1992 (Bergen: LOS-senteret, 1994) and Helge Pharo, Norge, Norden og europeisk integrasjon som etterkrigshistoriskforskningsfelt. EtterkrigshistoriskRegister, $n r$ 22, September 1991 (Bergen: LOS-senteret, 1994). A short introduction is Eriksen \& Pharo, Norway and the Early Cold War: Conditional Atlantic Cooperation (Oslo: Norwegian Institute for Defence Studies, 1993). The most recent work on Norway is Mats Berdal, The United States, Norway and the Cold War, 1954-60 (London: Macmillan 1997).

${ }^{3}$ Danish research has had a relatively higher profile in dealing with Denmark's relationship with European integration processes. Thorsten B. Olesen (ed.), Interdependence Versus Integration. Denmark, Scandinavia and Western Europe 1945-1960 (Odense University Press, 1995); Birgit Nüchel Thomsen (ed.), The Odd Man Out? Danmark og den Europaiske integration 1948-1992 (Odense: Universitetsforlag 1993). See also Carsten Holbraad, Danish Neutrality. A Study in the Foreign Policy of a Small State (Oxford: Clarendon Press, 1991), which spans more than 200 years of Danish foreign policy in less than 200 pages.

${ }^{4}$ Tuomo Polvinen, Between East and West: Finland in International Politics 1944-1947 (Minneapolis: University of Minnesota Press, 1986); Jukka Nevakivi, Maanalaista diplomatiaa vuosilta 1944-1948 jolloin kylmä sota teki tuloaan pohjolaan (Helsinki: Tammi 1983); Hannu Rautkallio, Paasikivi vai Kekkonen. Suomi lännestä nähtynä 1945-1956 (Helsinki: Tammi 1990). 
Power politics and Norwegian Foreign Policy from 1973. Skodvin was the first to emphasize the British interest in including Scandinavia in an Atlantic alliance. ${ }^{1}$ Udgaard pointed out how both Norway and Denmark were included in the first British plans for a Western bloc, but fell out of the inner circle of Britain's European partners in 1945-48 due to their bridge building policies and preference for nonalignment. Their inclusion in the Atlantic Pact completed a circular development and the return to Atlanticist policy and commitment. ${ }^{2}$ In 1976 Helge Pharo underlined the ambiguities in Britain's policy, as it was unclear what kind of alliance system eventually would emerge and how the Scandinavian countries would be included. ${ }^{3}$ Jukka Nevakivi pointed out that the explorations for a Scandinavian Defence Union (SDU) already started in 1946-47, before they came out in the open in $1948 .^{4}$ The main focus of all these authors, however, was not British policy as such. Their main concern was to analyse Norway's, and in Nevakivi's case Scandinavia's, international position, which was set against the great power interests in the region.

No study of Western policy towards Scandinavia in the cold war can pass over Geir Lundestad's account of US policy towards Scandinavia 1945-1949. ${ }^{5}$ Placing his research firmly within the debate on the origins of the cold war, Lundestad's interpretation of US foreign policy was closely in line with the post-revisionist arguments. A parallel, if thematically more limited, post-revisionist study to Lundestad's was Howard Turner's doctoral thesis, in which he compared British and US policies towards Scandinavian

\footnotetext{
${ }^{1}$ Magne Skodvin, Norden eller NATO? Utenriksdepartementet og alliansespörsmalet 1947-49 (Oslo: Universitetsforlaget, 1971).

${ }^{2}$ Nils Morten Udgaard, Great Power Politics and Norwegian Foreign Policy. A Study of Norway's Foreign Relations November 1940 - February 1948 (Oslo: Universitetsforlaget 1973).

${ }^{3}$ Helge Pharo, 'Det nordatlantiske samarbeid og Norge', Internasjonal Politikk, Vol. 34, No. 4 (1976), 859 - 897.

${ }^{4}$ Jukka Nevakivi, 'Scandinavian Talks on Military Cooperation in 1946-1947: A Prelude to the Decisions of 1948-1949', Cooperation and Conflict, Vol. 19, No. 2 (1984), 165 - 175.

${ }^{5}$ Lundestad, America, Scandinavia and the Cold War.
} 
defence 1945-49. ${ }^{1}$ Turner's main interest was in decision-making processes, elite images and perceptions of a limited number of key decisionmakers. His unpublished work has received less attention than it deserves, although his emphasis on what happened within the foreign policy elites in the US and the UK was at the expense of ascertaining the wider influence of Britain and the character of the cold war in Scandinavia. Turner's research was based on British and American archives, as most Scandinavian documentation was not yet available.

In 1981 Knut E. Eriksen and Magne Skodvin published an article on British policy towards Scandinavian defence cooperation, where the point was made that as long as Britain could not count on American military backing, a Scandinavian defence union was seen as a way out of a difficult strategic dilemma in northern Europe, where Britain did not have the resources for effective action. ${ }^{2}$ Nikolaj Petersen's research on British policy towards Scandinavia has highlighted the major interest of Britain in including the three Scandinavian countries in a Western defence arrangement. ${ }^{3}$ Norway's place in British defence strategy has been studied by Mats Berdal, Knut Einar Eriksen and Clive Archer. ${ }^{4}$ An exception among the defence oriented research are the articles by Bengt Nilson on the politics of Anglo-Scandinavian trade relations in the early 1950s, which follow the themes set out in his more extensive work on Anglo-Swedish economic relations in the

\footnotetext{
${ }^{1}$ Howard Turner, Britain, the United States and Scandinavian security problems 1945-49 (unpublished Ph.D.-thesis, Aberdeen University, 1982).

${ }^{2}$ Knut E. Eriksen \& Magne Skodvin, 'Storbritannia, NATO og et skandinavisk forbund', Internasjonal Politikk, Vol. 39, No. 3 (1981), 437 - 511.

${ }^{3}$ Nikolaj Petersen, Britain, the United States and Scandinavian Defence 1945-1949 (Aarhus: Institute of Political Science, University of Aarhus, 1980); Nikolaj Petersen, 'Britain, Scandinavia and the North Atlantic Treaty 1948-49', Review of International Studies, Vol. 8, No. 4 (1982), $251-268$.

${ }^{4}$ Mats Berdal, British naval policy and Norwegian Security. Maritime power in transition, 1951-60 (Oslo: Institute for Defence Studies, 1992); Knut Einar Eriksen, Storbritannia og Baseproblematikken i Norden 1945-1947 (Oslo: Forsvarhistorisk Forskningssenter, 1981); Clive Archer, Uncertain Trust. The British-Norwegian Defence Relationship (Oslo: Institute for Defence Studies, 1989).
} 
1930s. ${ }^{1}$

Despite, and perhaps because, the relative lack of primary research in Swedish postwar political history, the end of the cold war has resulted in a major reassessment and debate in Sweden of its role in the cold war. The debate was sparked off in 1990 when a number of highly critical revisionist arguments on the record of Swedish foreign policy in the cold war appeared. ${ }^{2}$ The leading revisionist writers, Wilhelm Agrell and Paul M. Cole, argued that the public should at last be made aware about the double standards that had guided Swedish foreign policy over the previous decades, when an officially neutral Sweden had in their view been a secret NATO member. ${ }^{3}$

This created a heated debate in Sweden, coinciding with a debate on the future of Sweden's neutrality in the European Union. Some senior foreign ministry officials who had served throughout the cold war came forward to defend the basic soundness, firmness and moral integrity of Sweden's policy of neutrality. ${ }^{4}$ Other researchers took

\footnotetext{
' Bengt Nilson, 'No coal without iron ore'; idem., 'Butter, Bacon and Coal: Anglo-Danish Commercial Relations, 1947-51', SJH, Vol. 13, No. 3 (1988), 257 - 77; idem., Handelspolitik under skärpt konkurrens. England och Sverige 1929-1939 (Lund: Bibliotheca Historica Lundensis LVII, 1983).

${ }^{2}$ Paul M. Cole, 'USA-samarbetet hemlighölls', Dagens Nyheter (DN), 21.10.1990; idem, 'Neutraliteten gavs upp', $D N$ 31.10.1990; idem, 'Lysande mörkläggning', $D N$ 3.2.1991; Bengt Nilson, 'Vi spelade dubbelt', $D N$ 6.11.1990; Wilhelm Agrell, 'Sverige tappade kontrollen', $D N$ 18.11.1990; idem, 'Vem styr "Firman"', DN 19.11.1990; Jonas Gummesson \& Thomas Kanger, 'Sanningen om den svenska neutraliteten', Aftonbladet 3.12.1990; See also the first article based on Cole's research Erik Magnusson, 'Sverige skulle tvingas med i Nato', Sydsvenska Dagbaldet Snällposten, (SDS), 28.10.1989.

${ }^{3}$ Wilhelm Agrell, Den Stora Lögnen (Stockholm: Ordfront, 1991); Paul M. Cole, Neutralité du Jour: The Conduct of Swedish Security Policy since 1945 (unpublished Ph.D.-thesis, Johns Hopkins University, Washington D.C., 1990). In the same category is also Cecilia SteenJohnsson, Ett folkbedrägeri. DC 3:an och svensk säkerhetspolitik. Sverige och Nato 1952-1992 (Stockholm: Carlssons, 1992).

${ }^{4}$ Sverker Ảström, 'Undén ingen Mr. Hyde', DN 7.11.1990; idem, 'Fram med bevisen!', $D N$ 5.1.1991; idem, 'Kampanj utan kunskap', DN 21.2.1991; Yngve Möller, 'Ingen kapitulation', DN 27.11.1990; Ảström's general argument is found also in Åström, Ögönblick.
} 
a less passionate and more analytical view of the controversy. ${ }^{1}$ Nonetheless, stirred by the debate, in 1992 the Swedish government set up the Commission on Swedish Neutrality Policy consisting of senior academics and officials and tasked to study Sweden's military contacts with Western powers in the cold war.

The work of the Commission was published in 1994. It revealed that extensive planning and preparatory work had been conducted in Sweden during the cold war in order to facilitate wartime cooperation with NATO if Sweden was attacked by the Soviet Union. These steps, nevertheless were not, according to the Commission's view, as extensive as some of the most critical revisionists had claimed, and neither did Swedish governments overstep the basic self-imposed boundaries of peacetime nonalignment. Even if planning and preparations had been done to facilitate military cooperation in war, no binding commitments were made. Politically Sweden was and remained neutral, even if at times, the public was not told everything of Sweden's preparations for different contingencies. The Commission also brought valuable new archival material in light about the British role in the exchange of military information with the Swedish service authorities in the post-1949 period. $^{2}$

The conclusion, that Sweden was and remained committed to the policy of neutrality in the cold war, had a mixed public reception. Some of the Commission's findings at first seemed to confirm the revisionist view that the policy of neutrality had been infringed in the 1950s. In particular the passing of defence information by Defence Minister Allan Vougt to the British in March 1951, and Prime Minister Erlander's official statement in 1959 which categorically, but misleadingly, ruled out any

\footnotetext{
${ }^{1}$ Birgit Karlsson, 'Neutraliteten - feg eller falsk', Göteborgs-Posten (GP), 21.7.1991; Lennart Berntson, 'Naivitetens och den dubbla bokföringens neutralitet', SDS, 1.6.1992; Karl Molin, Omstridd neutralitet. Experternas kritik av svensk utrikespolitik 1948-1950 (Stockholm: Tiden 1991); Bengt Nilson, Undéns tredje väg: Sverige i det kalla kriget, 1950-1952, Scandia, Vol. 60, No. 1 (1994), 67 - 97.

${ }^{2}$ Had there been $a$ war...
} 
preparations for or consultations on military cooperation with foreign powers, received critical public attention. ${ }^{1}$ Nevertheless, the report's general conclusion was not effectively disputed, even if some details, its periodisation and limited access to intelligence material were criticized. ${ }^{2}$ There were even some accusations that the commission's conclusions were too critical. ${ }^{3}$

Had There Been a War... is still at the moment the most exhaustive monograph, based on extensive research, of a particular aspect of Sweden's cold war. The fact that it was officially sponsored is testimony to the importance of the neutrality issue in Sweden. The report itself does not claim to be the final word, and explicitly encourages further research of which this thesis may hopefully be seen to be a part. The 1990s has seen the beginning of the study in earnest into Swedish postwar political history. ${ }^{4}$ These are the contemporary debates about the past this thesis has to be seen against.

${ }^{1}$ Mikael Holmström, 'Nato-hjälp redan före angrepp', $S v D, 9.2 .1994$; idem \& Ingmar Lindmarker, 'Nato fick Sveriges försvarsplaner', $S v D$, 8.2.1994; Mikael Holmström. 'Fast förbindelse med USA:s flygvapen' \& 'Stor skillnad mellan politik och retorik', SvD, 13.2.1994.

2 Jan Guillou, 'Opportunism som statskonst', SDS, 15.2.1994; Kenth Olsson, SDS, 19.2.1994.

${ }^{3}$ Sverker Ȧström, 'Erlander kan inte anklagas för medveten lögn', $S v D, 23.2 .1994$; idem, 'Erlander kunde ha uttryckt sig klarare', $S v D, 23.3 .1994$.

${ }^{4}$ Gerald Aalders, Swedish Neutrality and the Cold War 1945-49 (Amsterdam, 1989); Gerald Aalders, 'The failure of the Scandinavian defence union, 1948-1949', SJH, Vol. 15, No. 1 (1990), 125 - 153; Annie Lacroix-Riz, L'économie suédoise entre l'est et l'ouest 1944-1949: Neutralite et embargo, de la guerre au pacte atlantique (Paris: L'Harmattan, 1991); Birgit Karlsson. Handelspolitik eller politisk handel; Birgit Karlsson, 'Neutrality and Economy: The Redefining of Swedish Neutrality, 1946-52', Journal of Peace Research, Vol. 32 No. 1, (1995), 37 - 48; Mikael af Malmborg, Den ständaktiga nationalstaten. Sverige och den västeuropeiska integrationen 1945-1959 (Lund: Lund University Press, 1994); Cay Sevón, Visionen om Europa. Svensk neutralitet och europeisk àteruppbyggnad 1945-1948 (Helsinki: Suomen Historiallinen Seura, 1995); Thomas Jonter, Socialisering som kom av sig... Sverige, oljan och USA:s planer pä en ny ekonomisk världsordning 1945-1949 (Stockholm: Carlssons, 1995); Alf W. Johansson, Herbert Tingsten och det kalla kriget. Antikommunism och liberalism i Dagens Nyheter 1946-1952 (Stockholm: Tiden, 1995); Molin, Omstridd neutralitet. For an outline of the research program 'Sweden in the Cold War' see Ann-Marie Ekengren, Sverige under kalla kriget 1945-1969. En forskningsöversikt (Göteborg: Statsvetenskapliga institutionen, Göteborgs Universitet, 1997). 
The legacy of war

Before 1939 Britain's relations with the Scandinavian countries rested 'on a combination of economic strength, naval power and political goodwill'. ${ }^{1}$ Britain had been accustomed to the dual role as 'client-in-chief and banker', thereby considering the region primarily in economic terms. ${ }^{2}$ The level of Scandinavia's economic dependence on Britain had led Ashton Gwatkin, an economic specialist in the FO to go as far as to describe Scandinavia 'as a kind of unacknowledged economic empire of which London is the metropolis' ${ }^{3}$ The only power capable of challenging Britain's economic primacy in Scandinavia had been Germany. During the Second World War this economic challenge was transformed into a military-strategic threat, highlighting strategic and political considerations in Britain's relations with the Scandinavian countries. The wartime experience made it clear how a Scandinavia controlled by a hostile power could be a serious threat to Britain's vital interests, especially its sea communications. In addition to the increased awareness of Scandinavian strategy in London, the relative indifference towards Scandinavian neutrality was replaced by a more keen interest in the future circumstances under which Britain might have to respond to developments in Scandinavia. ${ }^{4}$

On the political and diplomatic plane, the war established Norway especially as a close ally of Britain, with an exiled government and king in London and with extensive

\footnotetext{
${ }^{1}$ Peter Ludlow, 'Britain and Northern Europe, 1940-1945', SJH, Vol. 4, No. 2 (1979), 123 162. A comprehensive account of Scandinavia in international politics before the Second World War is Patrick Salmon, Scandinavia and the Great Powers 1890-1940 (Cambridge, Cambridge University Press, 1997).

${ }^{2}$ Phrase by Ludlow, in ibid.

${ }^{3}$ Quoted in ibid.

${ }^{4}$ For the evolution of British wartime thinking towards Sweden, see Victor Mallet's unpublished memoirs, Sir Victor Mallet Papers, Churchill College, Cambridge.
} 
political and military-technical ties that continued after the liberation. ${ }^{1}$ An AngloNorwegian 'special relationship' was strengthened by personal contacts between the political, military and economic élites, which the common war experience solidified. ${ }^{2} \mathrm{~A}$ similar situation, although to a lesser extent, existed with Denmark. This development towards closer Anglo-Norwegian and Anglo-Danish relations was offset by increased Soviet influence in Finland and in the annexed Baltic republics; by and large across the Baltic Sea's eastern littoral as a whole. The territorial settlements brought the Soviet Union also a direct neighbour of Norway in the high north, at first with troops in northern Norway (Øst-Finnmark) and in the Danish island of Bornholm. During the last days of the war, the British were alarmed lest the Red Army succeed in landing on the island of Zealand in Denmark as well, but it was in the end narrowly liberated by Field Marshal Montgomery's troops. ${ }^{3}$

Attitudes in London towards Sweden were somewhat ambiguous. The Second World War was a very different experience for Britain and Sweden. While the Swedes could find consolation in their success of keeping their country out of the war, feelings in Britain of this were a mixture of resentment and realism. First, in early 1940, the Swedes had been against allied intervention in the Finnish-Soviet Winter War through its territory. Then in April 1940, they, to the great dismay of Winston Churchill, remained spectators when Denmark and Norway were overrun by Germany. ${ }^{4}$ In 1941 Sweden permitted the transit of fully equipped German troops across its territory to the eastern

1 The standard account is Olav Riste, "London-Regjeringa". Norge $i$ krigsalliansen 19401945, Vol 1, 1940-1942: Prøvetid (Oslo: Det Norske Samlaget, 1973); Vol 2, 1942-1945. Vegen heim (Oslo: Det Norske Samlaget, 1979).

${ }^{2}$ Salmon has pointed out the significance of the wartime experience in enhancing both the knowledge of Scandinavia in Britain and the importance of the personal contacts. Salmon, 'Great Britain and Northern Europe', 211.

${ }^{3}$ Captain Henry M. Denham's memoir, Denham papers, Churchill College, Cambridge. Printed as Henry Denham, Inside the Nazi Ring: A Naval Attaché in Sweden 1940-1945 (London: Murray, 1984).

${ }^{4}$ Martin Gilbert, Churchill. A Life (London: Heinemann 1991), 664. 
front, in violation of its neutral status and precisely the concession the Allies were refused a year before. ${ }^{1}$ Even more problematic was that until 1944 Sweden continued its flourishing trade with Germany. While Sweden could retain its economy in a healthy condition, the German war machine was supplied among other things with vital iron ore and ball bearings.

All this caused considerable resentment towards Sweden especially in the US. It was also displayed in Winston Churchill's emotional outburst about the 'distasteful intrusion' of 'the ignominious king of Sweden' as a peacemaker in the summer of 1940, or by the strongly anti-Swedish head of the FO's Northern Department Laurence Collier's acid remarks about the moral qualities of the leading Swedes. ${ }^{2}$ As against the advice from the more cautious FO, Churchill was also keen to press Sweden into the war against Germany. ${ }^{3}$ Due to its neutrality, Sweden was not invited to the San Francisco conference in April 1945 to set up the United Nations; the British diplomatic mission in Stockholm was kept at legation level and there was also a tendency in the FO to speak against any favourable treatment of Sweden in trade questions. ${ }^{4}$ However, as will be seen later, penalising Sweden commercially for its neutrality was hardly a sustainable line given Britain's postwar economic austerity.

On the other hand, and especially higher up in the FO hierarchy, Sweden's difficult position had been acknowledged by a number of British policymakers who would have a central role in shaping postwar Anglo-Swedish relations. Sir Orme Sargent, then deputy under-secretary, sympathised with Sweden during the 1941 transit controversy by saying

\footnotetext{
1 Wilhelm M. Carlgren, Svensk utrikespolitik 1939-1945 (Stockholm, Allmänna Förlaget, 1973), 299 - 314.

${ }^{2}$ Ludlow, 'Britain and Northern Europe', 142, 137.

${ }^{3}$ Leif Leifland, "They must get in before the end". Churchill och Sverige 1944 och 1945', Mats Bergquist, Alf W. Johansson \& Krister Wahlbäck (eds.), Utrikespolitik och historia. Studier tillägnade Wilhelm M. Carlgren den 6 maj 1987 (Stockholm: Militärhistoriska Förlaget, 1987), $113-143$.

${ }^{4}$ Eriksen \& Skodvin, 'Storbritannia, NATO og et skandinavisk forbund', 437 - 511.
} 
that 'their intentions are excellent but their position is hopeless' ${ }^{1}$ Also the British wartime mission in Stockholm, and its head Sir Victor Mallet in particular, was keen to promote a more understanding and benevolent attitude towards Swedish neutrality in London. ${ }^{2}$

With the turn of tide in the war in 1943, Anglo-Swedish relations began to improve, to the extent that it aroused resentment among Norwegians that the Swedish representatives were treated 'as though Sweden were an ally'. ${ }^{3}$ After the German defeat at Stalingrad and after pressure from Britain and the US, the Swedes agreed to end the 1940 transit agreement with Germany and steadily began to diminish their German trade. In 1944 pressure from the US grew further and in autumn 1944 the direction of Swedish foreign policy began to move rapidly. ${ }^{4}$ Despite the FO's attempts at moderation, Sweden's pro-German bias had received considerable criticism from the US. ${ }^{5}$ To appease the big three and following strong American pressure, Sweden closed its Baltic ports to German shipping in August 1944, leaving Germany's supply lines from Norway exposed to allied forces and effectively put an end to its trade with Germany. The Swedes also cooperated with the British in gathering intelligence on the German V2-rocket testing and let interned American aircrews return to Britain in $1945 .{ }^{6}$ On the economic front, AngloSwedish timber trade began again to flow in late 1944 - early 1945 . The cloak of neutrality was dropped, in the words of the British Consul in Malmö, with rapidity

\footnotetext{
${ }^{1}$ Quoted in Ludlow, 'Britain and Northern Europe'.

${ }^{2}$ A fine example of Mallet's pro-Swedish views is his final report from Stockholm in 1945, Mallet to Eden, 17.6.1945, FO 371/48042. Nonetheless, according to Ludlow, internal divisions existed in the British legation in Stockholm as well. Ludlow, 'Britain and Northern Europe', 137 ftn. 67.

${ }^{3}$ Ludlow, 'Britain and Northern Europe', 150.

${ }^{4}$ Carlgren, Svensk utrikespolitik 1939-1945, 430 - 436, 545 - 552.

${ }^{5}$ Alf W. Johansson, 'Sverige och västmakterna 1939-1945', Stig Ekman (ed.), Stormaktstryck och smàstatspolitik. Aspekter pả svensk politik under andra världskriget (Stockholm: Liber, 1986).

${ }^{6}$ Brief to Air Chief Marshal Tedder, undated, FO 371/48035; 'Britain received advance news about V-Bombs', The Anglo-Swedish Review, November 1945; RAF delegation (Washington) to Air Ministry 21.2.1945, FO 371/48024, PRO.
} 
roughly in proportion to speed of the advance of the Russians. The perceived tendency was not, however, to look towards the Russians or even towards the tougher Americans, but towards the British. ${ }^{1}$

When the war reached its final phase, there was also more optimism, fuelled by Mallet from Stockholm, that Sweden would eventually voluntarily abandon its neutrality and associate itself in the future with the West. ${ }^{2}$ There was also in 1944-45 a stronger awareness and commitment in the British government to integrate Sweden into a planned Western group, especially in the economic sphere. ${ }^{3}$ The British were hopeful that Sweden would end its cultural and economic orientation towards Germany and that more intimate relations in these spheres would be established with the Anglo-Saxon powers, especially with Britain. ${ }^{4}$

Nevertheless, what became clear during the war was that the British possessed very limited means 'either to hurt or to help Sweden in the short term'. ${ }^{5}$ The British were in no position to balance the German wartime predominance in northern Europe. This was a situation that might emerge also after the war in a less salient way with the Soviet Union. Both Germany and the Soviet Union could by their sheer physical presence effectively constrain the options open for British policy-makers as it made the Swedes less amenable neither for pressure nor incitement from Britain.

\footnotetext{
${ }^{1}$ Frank Bishop to G. Labourchere, 10.2.1945, FO 371/48041.

${ }^{2}$ Ludlow, 'Britain and Northern Europe', 151.

${ }^{3}$ Ibid., 156 - 157.

4 'Swedish Foreign Policy', FO memorandum, 10.8.1945, FO 371/48042.

${ }^{5}$ Ludlow, 'Britain and Northern Europe', 142.
} 
Bevin's 'grand design' and Stalin's intentions

The wartime experience left the British postwar planners with the view that Norway and Denmark belonged to a British sphere of interest and Scandinavia as a whole should be an integral part of the plans for the postwar settlement in Europe. That Norway and Denmark belonged to a British sphere was also the understanding reached in Foreign Secretary Anthony Eden's talks with Joseph Stalin in December 1941, who made it clear that he had no objection to British military bases in Denmark and Norway in the future. ${ }^{1}$ Sweden, significantly enough, was not mentioned in this connection. Hopes ran high that in peacetime Britain would also continue to exert strong influence in Scandinavia through these countries. ${ }^{2}$ This was augmented by the fact that the Americans were not yet particularly interested in Scandinavia. ${ }^{3}$ The main US interest was in the military bases it had occupied during the war in Greenland and Iceland. However, not even the future of those bases was settled when the war ended.

The main British objective after the war towards Scandinavia was to tie Norway and Denmark as closely as possible to the British sphere of interest and at the same time to influence Sweden's foreign policy into a more Westerly oriented direction. ${ }^{4}$ The best means to achieve this was to tie the Scandinavian countries closer to Britain by military, economic and political means. This general aim was visible in Bevin's so-called 'grand design' of August 1945, in which Britain's future role in Western Europe was based on building cooperation with the continent on a wide front, on political, military and economic levels. The most important step was an alliance with France, but on this basis

${ }^{1}$ Ludlow, 'Britain and Northern Europe', 138 - 139.

${ }^{2}$ Eriksen \& Skodvin, 'Storbritannia, NATO og et skandinavisk forbund', 437 - 511.

${ }^{3}$ Lundestad, America, Scandinavia, and the Cold War, 43 - 44.

4 Warr minute 30.5.1946, FO 371/56225; Turner, Britain, the United States, and Scandinavian Security Problems 1945-1949, 89. 
Britain's links could be extended to the Low Countries, Italy, Greece and Scandinavia. ${ }^{1}$

Bevin was relatively new to Scandinavian issues when he became foreign secretary and at first followed the advice of his officials. His inexperience was witnessed in the way he initially, at least in the eyes of the Swedish ambassador, had some trouble in figuring out the exact geographic lineup of these countries. ${ }^{2}$ Furthermore, Bevin's 'grand design' echoed earlier thinking in the FO of a Western bloc. ${ }^{3}$ In wartime schemes put forward in the FO for a future regional cooperative framework in Western Europe, Scandinavia, and Norway and Denmark in particular, were mentioned alongside France and the Low Countries as Britain's postwar partners in Western Europe from the outset. ${ }^{4}$ The chances for the inclusion of Norway and Denmark in any postwar bloc were thought to be greater immediately after the war, when the wartime alliance was still fresh in mind. ${ }^{5}$ The significance of the wartime ties was seen when, for example, still in 1946, when both the Norwegians and the Danes had distanced themselves from the wartime alliance and put forward their bridgebuilding policies, the British in their official language made a distinction between 'the two Allied Scandinavian countries' and 'neutral Sweden' ${ }^{6}$

The Swedes, nonetheless, were not left out of the wider picture. In conversations in October 1945 with Sven Grafström, the head of the Political Department in the Swedish Foreign Ministry, both the head of the Northern Department Christopher Warner and Permanent Under-Secretary Sargent stressed the need for 'intimate political cooperation'

\footnotetext{
' Hoyer-Millar minute, 13.8.1945, FO 371/49069; Young, Britain and European Unity, 1945-1992, 1.

${ }^{2}$ Gunnar Hägglöf, Fredens Vägar, 1945-1950 (Stockholm: P. A. Norstedt \& Söner, 1973), 200.

${ }^{3}$ Greenwood, Britain and European Cooperation Since 1945, 8; Turner, Britain, the United States, and Scandinavian Security Problems 1945-1949, 30.

${ }^{4}$ Lord Gladwyn, The Memoirs of Lord Gladwyn (London: Weidenfeld and Nicolson, 1972), $140-141$.

${ }^{5}$ A. F. Haigh minute, 24.6.1945, FO 371/48042.

${ }^{6}$ Warr minute, 17.5.1946, FO 371/56224.
} 
between Britain and the northern countries. ${ }^{1}$ Anticipating future lines of British policy, their view was that this could be achieved without formal agreements or treaties. ${ }^{2}$ The Western bloc, however, was not to leave the drawing board, and the wartime alliance with Norway and Denmark also gave way in 1945-47 to a more detached relationship. Several Scandinavian historians have described how during this period, instead of developing closer relations with the West, Norway spoke for bridgebuilding between East and West, and Denmark's policy was characterised by its 'non-aligned neutrality' ${ }^{3}$ This, in contrast with the Benelux countries, subsequently led them to distance themselves from London in the initial postwar period. ${ }^{4}$ This disappointed the British at first, but led them to propose a similar solution as with Sweden, that is, to 'aim at some practical arrangements' instead of open alliances. ${ }^{5}$

During 1945 apprehension about the prospect of continuing the wartime Anglo-Soviet cooperation grew in the FO and among the British military planners. Sir Orme Sargent put forward his views of Britain's long term policy in July 1945 in his celebrated 'Stocktaking' memorandum, where he advocated a tougher approach towards the consolidation of Eastern Europe as an exclusive Soviet sphere. ${ }^{6}$ But despite the hardening of attitudes on the official level, the political decisionmakers were not yet prepared for

'Sven Grafström's diary 6.10.1945, in Stig Ekman (ed.), Sven Grafström, Anteckningar 1945-1954 (Stockholm: Kungl. Samfundet för utgivande av handskrifter rörande Skandinaviens historia, Handlingar del 15, 1989), 697 - 698.

${ }^{2}$ Ibid.

${ }^{3}$ Skodvin, Norden eller NATO?, 20 - 21; Udgaard, Great Power Politics and Norwegian Foreign Policy, 91 - 96; Erik Noreen, Brobygge eller blockbildning? De norska och svenska utrikesledningarnas säkerhetspolitiska föreställningar 1945-1948 (Stockholm: Carlssons, 1994), 54 - 67; Holbraad, Danish Neutrality, 86 - 107.

${ }^{4}$ Eriksen \& Skodvin, 'Storbritannia, NATO og et skandinavisk forbund', 437 - 511.

${ }^{5}$ Ibid., 443.

${ }^{6}$ Sargent memorandum 'Stocktaking after VE-day', 11.7.1945, in Rohan Butler \& M. E. Pelly (eds.), Documents on British Policy Overseas (DBPO). Series I Volume I (London: HMSO 1984), 181 - 191. 
an open showdown with the Russians. ${ }^{1}$ The alternative, a traditional sphere of influence deal, was put forward by the influential, Bevin's favourite 'Mr. Minority', Sir Gladwyn Jebb. ${ }^{2}$ In his vision Eastern Europe would have been implicitly recognised as a Soviet sphere, together with the Eastern part of Germany. Western Germany, Western Europe (including Sweden), Italy, Greece, Turkey, the Mediterranean in general and Iran would have remained in the West's exclusive sphere. The development towards closer AngloSwedish relations that had started in 1943 was displayed by the fact that Sweden was now expicitly mentioned by Jebb as a part of the British sphere in Western Europe, where the Russians would have to keep their 'hands off' ${ }^{3}$ No such settlement was, of course, ever reached, and the subsequent East-West division, that essentially followed these lines, was reached through political confrontation and not at the negotiation table.

At first, however, Scandinavia seemed to be a quiet spot in the emerging tension between Britain and the Soviet Union. By August 1945 Britain's relations with the Nordic countries were normalising quickly. Wartime cooperation with Norway continued on the military and political fields. The British signed a financial agreement with Denmark, aimed at securing the supply of essential Danish agricultural products. The opening up of the Baltic Sea helped trade to expand with Sweden. With Finland, the British were exchanging political representatives, although without a peace treaty the resumption of full diplomatic relations had to wait. ${ }^{4}$

However, with the general worsening of Anglo-Soviet relations in autumn 1945, the Scandinavian countries were also dragged into this debate. Replying to Soviet criticism against a Western European bloc in the House of Commons on 7 November, Bevin defended the right of Britain to have 'good relations with nations bordering on the British

\footnotetext{
'Bullock, Ernest Bevin, 117, 138, 159, 191 - 192.

2 Bevin's nickname for Gladwyn Jebb. Lord Gladwyn, The Memoirs, 176.

${ }^{3}$ Lord Gladwyn, The Memoirs, 172.

${ }^{4}$ FO telegram to Oslo, Stockholm, Copenhagen and Helsinki, 21.8.1945, FO 371/47450.
} 
frontier'. ${ }^{1}$ Speaking freely and abandoning his prepared text, Bevin said:

What HM Government are willing to give, they claim the right to have, for their part, with France, with Holland, Belgium, Scandinavia or other countries - not a Western bloc for war purposes. They are our cultural friends; they are our historical associates; they acknowledge the same democracy as we do and therefore I say that I am entitled, on behalf of HM Government, to have good neighbours in my street just as any other country is. ${ }^{2}$

The reference to Scandinavia served a double purpose: to make clear to the Soviet Union where Britain thought its sphere in Europe laid, but also to show to the section within the Labour party that expected a less antagonistic policy towards the Soviet Union that Britain's cooperation with its neighbours was not about building an anti-Soviet alliance. Mentioning the Scandinavians, who were good social democrats and followed a policy of fostering better relations with the Soviet Union, was additional proof that Bevin's policy aspired for this same partnership with Stalin. To use the rhetoric from an age yet to come, within Labour, cooperation with the Scandinavians was politically correct.

If Britain's relations with Sweden remained intricate due to the legacy of war, Britain's view of Finland's position was hardly encouraging. Leaving aside concerns arising from any possible residue of popular sympathies in Britain towards 'the splendid northern race', the Soviet Union seemed to exert an alarmingly strong influence in - and via - Finland, after Germany's predominance had disappeared. ${ }^{3}$ This was potentially endangering the whole position of Britain in Scandinavia. In October 1945, an early case for British containment of Soviet influence in northern Europe was developed.

\footnotetext{
${ }^{1}$ Bullock, Ernest Bevin, 192.

${ }^{2}$ An observation in Eero A. Wuori to Carl Enckell, 23.11.1945, Microfilm 5 C. Archives of the Finnish Ministry of Foreign Affairs (AFMFA), Helsinki; Bullock, Ernest Bevin, 192.

${ }^{3}$ Churchill's phrase in a radio speech on 20.1.1940, quoted in Martin Gilbert, Finest Hour. Winston S. Churchill 1939-1941 (London: Book Club Associates, 1983), 136 - 137. On popular goodwill towards Finland, see Wuori to Enckell, 2.10.1945, AFMFA.
} 
Colonel James H. Magill, a member of the Allied Control Commission in Helsinki, was the first to advocate a more coordinated British policy in the Nordic region, seeing the Soviet Union in Finland developing a potentially dangerous platform for its 'complete domination of the whole of Scandinavia'. Magill assumed that Britain's main object was to prevent this, 'since in time of peace this would interfere with our trade and in time of war would mean that parts of Scandinavia could be used as a base for operations against Great Britain and her sea communications'. ${ }^{1}$ Scandinavia seemed to be a vacuum, which in time of crisis would be automatically filled from the east. To prevent this, Britain should offer assistance to the Scandinavian countries and help them to gain confidence and develop closer Scandinavian cooperation. A strong Scandinavian bloc would be able to counter Soviet pressure better, but this would need more assuring policies from Britain. To ensure this, Britain needed to let the Scandinavians know that it did not intend to let them to 'slide unresisting into the jaws of Russia'. Britain needed to coordinate its policies towards Scandinavia in general and towards Sweden, 'the key to the problem', in particular. ${ }^{2}$

Magill took it for granted that the Soviet Union was expanding its sphere of influence in the north. The problem, which was highlighted in the FO, was with the evidence of Soviet intentions. In the Northern Department the general feeling in November 1945 still was, that this conclusion was 'premature, to say the least of it' ${ }^{3}$ The FO needed more factual details and evidence about Soviet intentions, before a coordinated containment policy could be formulated for Scandinavia. Although the evidence provided by Magill

${ }^{1}$ Colonel J. H. Magill to Captain Howie (Allied Control Commission), 30.10.1945, FO $371 / 47450$.

${ }^{2}$ Magill to Howie, 30.10.1945, FO 371/47450.

${ }^{3}$ G. M. Warr minute 11.11.1945. Also minutes by Thomas Brimelow, 12.11. and C. F. A. Warner, 25.11, FO 371/47450. In his memoirs Magill later admitted that his alarmism had been premature. J.H. Magill, Tasavalta tulikokeessa. Muistelmia Suomesta kuuman ja kylmän sodan vuosilta (Mikkeli: Weilin+Göös, 1981), 106 - 107. 
seemed slender, it was supported by the British Charge of D'Affairs in Helsinki, Francis Shepherd. Thomas Brimelow from the Russian desk in the Nothern Department likewise thought Magill's views 'a pretty fair summary of the admittedly limited and inconclusive evidence available'. ${ }^{1}$

By early 1946, the general mood and thinking about Stalin's intentions was rapidly changing in the FO. ${ }^{2}$ This led Magill's and Shepherd's warnings to be taken more seriously in February 1946 when those who were previously sceptical found themselves in agreement with the more pessimistic conclusions. ${ }^{3}$ It therefore seems, that the major shift in the FO's thinking of the challenge posed by the Soviet Union in the Nordic region took place between November 1945 and February 1946, as a part of a general trend and crystallisation of a negative image of Soviet intentions. ${ }^{4}$ The perception of hostile Soviet intentions on a wide front of issues and areas was particularly important to the way the policymakers immediately responsible for Scandinavian affairs in the FO, Christopher Warner and Robin Hankey, now saw Scandinavia. ${ }^{5}$ The position of Finland itself was not the main issue, but the influence the Soviet Union might be able to exert beyond Finnish borders to Scandinavia was the main source of concern.

The ensuing problem therefore was how and where to build a front against this perceived spreading of Soviet influence. Where should the line between the British and Soviet spheres of influence be drawn in the north? Should Finland still be considered as a part of Scandinavia? Was the example of Sweden, which the British thought had despite

\footnotetext{
${ }^{1}$ Brimelow minute, 12.11.1945, FO 371/47450.

${ }^{2}$ Frank Roberts, Dealing with Dictators. The Destruction and Revival of Europe 1930-70 (London: Weidenfeld \& Nicolson 1991), 107 - 110.

${ }^{3}$ Warner minute 12.2 .1946 , FO $371 / 47450$.

${ }^{4}$ This is somewhat earlier than has been assumed by previous authors. Skodvin, Nordic or North Atlantic Alliance?, 12; Turner, Britain, the United States, and Scandinavian Security Problems, 1945-49, 26 - 27, 36 - 38.

${ }^{5}$ Salmon, 'Great Britain and Northern Europe', 212.
} 
popular sentiments written Finland off as a member of the Nordic community in $1946,{ }^{1}$ to be followed also by the British? In 1946, the solution was to try to contain the Soviet Union in Finland in all other respects than on the military plane, namely by keeping Finland economically and culturally linked with the West. ${ }^{2}$ The military plane was obvious in the cases of Norway and Denmark, as they already had close technical contacts with the British armed forces. However, where this policy would have its most difficult test was in Sweden.

\section{$A$ fresh start with Sweden}

Swedish neutrality had been a longstanding problem for Britain in the Nordic region. All evils were also afterwards easily attributed to Sweden's unilaterally declared policy of neutrality, even if Sweden initially after the war put international cooperation and collective security provided by the United Nations Charter ahead of its strict neutrality. ${ }^{3}$ In October 1945 the Swedish government's formulation was:

We are willing to participate in a joint security organisation and, in the event of a future conflict, to give up neutrality to the extent that the Charter of the organisation demands. If, however, against expectation a tendency towards a subdivision of the Great Powers in two camps would appear within this organisation, our policy must be not to let ourselves be forced into such a group or bloc formation. ${ }^{4}$

\footnotetext{
${ }^{1}$ Annual report on Sweden for 1946, FO 371/66513.
}

${ }^{2}$ F. M. Shepherd to Bevin, 24.11.1945; Warner to Shepherd, 26.2.1945, FO 371/47450.

${ }^{3}$ Ove Bring, 'Neutralitet contra kollektiv säkerhet', The Royal Swedish Academy of War Sciences, Proceedings and Journal, Vol. 196, (1992), 423 - 329.

${ }^{4}$ Government Message to Parliament on 22.10.1945, quoted in Brodin \& Goldmann \& Lange, 'The Policy of Neutrality', 18 - 51. 
When this tendency became an actuality in the cold war, the proponents of the policy of aloofness in Sweden were at first seen as the main obstacles to Britain's interests. As Sweden was the major Nordic power, it could effectively limit the options of its smaller neighbours. At the same time, the record of Swedish wartime neutrality was dubious. In British eyes, it followed the currents of realpolitik, meaning that the strongest power, or the current constellation of power in its neighbourhood, defined the content of its neutrality. Now it was Britain's time to contribute to that process. Paradoxically perhaps, the first step was to adopt a more benevolent attitude towards the form of Swedish foreign policy.

The frustrations of the British in this project were many. After the Swedish Foreign Minister Christian Günther gave another strong speech in favour of postwar neutrality in early May 1945, the normally sympathetic Mallet reflected this attitude in his comments: 'It is always irritating to hear a Swede speak of neutrality as if it were some remarkable achievement or discovery of Swedish statesmanship which all the world should admire'. ${ }^{1}$ The new Swedish Foreign Minister, Östen Undén, who was appointed in June 1945, hardly seemed an improvement. Having already before the war achieved a reputation of 'failing to appreciate the British character', Undén, during his seventeen years (1945-62) in the Swedish Foreign Ministry, more than anyone else became to embody Sweden's policy of neutrality in the cold war. ${ }^{2}$ A professor of international law, its advanced theorist and practitioner, Undén's view of international affairs was a mixture of realism and legalism, especially in the context of the defence of the rights of small states in great power politics. ${ }^{3}$ Not so much a neutrality dogmatist as a stubborn defender

\footnotetext{
${ }^{1}$ Mallet to Eden, 29.5.1945, FO 371/48042.

${ }^{2}$ Personality Report, Östen Undén, 21.8.1944, FO 371/43511.

${ }^{3}$ Krister Wahlbäck, 'Neutralitet och solidaritet. Ett dilemma i svensk säkerhetspolitik 19201996', Leif Leifland (ed.), Brobyggare. En vänbok till Nils Andrén (Stockholm: Nerenius \& Santérus, 1997); Yngve Möller, Östen Undén. En biografi (Stockholm: Norstedts, 1986), 538 551.
} 
of Sweden's realpolitik interests and rights to remain outside the quarrels of others, he nonetheless was soon realised to be the immovable obstacle blocking the way for Sweden's open alignment with the West. However, despite Undén, changes in AngloSwedish relations were already underway on different levels when the war ended.

During the later stages of the war, the strategic significance of Sweden increased, especially from the viewpoint of the British air force. Flying over Sweden was seen as imperative when attacking targets in North-Eastern Germany. ${ }^{1}$ If the next war was to be fought against the Soviet Union, then this would be even more necessary. Denmark and all of southern Sweden were along the direct air routes to important parts of northern Soviet Union. ${ }^{2}$ The main British preoccupation with Sweden at this stage, besides resuming trade contacts, was to find ways to fill the strategic lacuna left by the elimination of Germany. The minister in Stockholm, Sir Bertrand Jerram was worried that a failure to do this would lead the Swedes to look east or 'over our heads to the extreme West'.3

When the deputy commander of the Royal Air Force, Air Chief Marshal Sir Arthur Tedder, planned a visit to Oslo on the occasion of King Haakon's return to Norway in May 1945, the British representatives in Stockholm recommended strongly that he should extend his visit to Sweden. This was also the wish of the chief of the Swedish air force, General Bengt Nordenskiöld, who regarded the cultivation of contacts with the RAF as a very high priority. ${ }^{4}$ Tedder's visit had also importance as it could 'offset the recent visits by American generals', who fostered closer ties with the Swedes and worked to strengthen American aviation interests in Scandinavia, which was an important market

\footnotetext{
${ }^{1}$ Warr minute 18.1 .1945 , FO $371 / 48025$.

${ }^{2}$ The first thorough asessments of Scandinavia's strategic importance were in a Joint Planning Staff (JPS) report 'Scandinavian defence - strategic considerations', JP(47)56 (FINAL), 4.6.1947, DEFE 4/4, PRO.

${ }^{3}$ Jerram to FO, 3.9.1945, FO 371/48035.

${ }^{4}$ Report on Personalities in Sweden 1944, FO 371/43511.
} 
for British aircraft. ${ }^{1}$ The concern of the British representatives in Stockholm was shared by Nordenskiöld, who told them that closer ties with Britain could help to relieve the pressure put on them by the Americans. ${ }^{2}$ Tedder's visit was a move in a game to bring Sweden's armed forces and especially its air force, which was the second largest in Western Europe after the RAF, into closer contact with Britain.

The British had learned from their mistakes in the past, as cultivating the Swedish armed forces had been neglected before the war. Britain had failed to establish friendly relations with the Swedish military, especially the army officers. This had left the field open for the Germans and during the war this had contributed to the extent that the Swedes felt closer to the German military machine, which a large part of the Swedish military establishment had regarded highly from a professional point of view. It was feared that to neglect the Swedes now, would throw them again on the side of the strongest neighbour or into neutral and possibly dangerous isolation. ${ }^{3}$

Tedder's visit was received well in Sweden. The chief of the British bomber command, Air Chief Marshal Sir Arthur 'Bomber' Harris followed suit in July 1945. The established, friendly relations between the air forces in Britain and Sweden were, and had been better than the relations between Sweden's traditionally more pro-German navy and army. To counter this imbalance, a British naval visit to Sweden was arranged in the autumn of 1945. The British naval visit was hastened after a Russian request for a similar visit. ${ }^{4}$ After a hint from the Swedish navy, it was considered important that the British navy should be the first to visit Sweden, before the Russians, who evidently were trying to assert their influence as a newly re-established naval power in the Baltic. ${ }^{5}$ Still in war

\footnotetext{
'Air attaché's telegram to Air Ministry (AIR), 27.5.1945, FO 371/48035.

${ }^{2}$ Brief to Air Chief Marshal Tedder, undated, FO 371/48035.

${ }^{3}$ Air attaché's report 6.6.1945, FO 371/48035.

${ }^{4}$ Naval attaché's telegram to Admiralty (ADM), 1.9.1945, FO 371/48035.

${ }^{5}$ Warner minute 5.9.1945, FO 371/48035.
} 
paint but rigged fore and aft by festival lighting the navy units supported a hectic October week of public relations exercises. After a long absence from the Baltic, the Union Jack was successfully shown above deck, while below deck the first glimpse of modern radar technology was displayed to selected Swedish navy officers. ${ }^{1}$

After the naval visit, General Sir Andrew Thorne, the allied commander in Norway, paid a visit to Sweden as well. He was the first British senior army officer to visit Sweden and his counterparts seemed remarkably forthcoming. General Helge Jung, the pro-Western supreme commander spoke warmly to him about ending Sweden's wartime isolation. General Archibald Douglas, the chief of the Swedish army, seemed also to inove rapidly away from his wartime pro-German bias. Douglas approached the British military attaché after Thorne's visit and told him that he hoped more contacts could be made, 'for Sweden is in a difficult position and we have no desire to become a second Poland' ${ }^{2}$ Also intelligence collaboration that was initiated at the last stages of the war was continued, although initially only on the naval side. ${ }^{3}$

While working for closer unofficial relations with the Swedish armed forces, the shadow of the experience of the Second World War still loomed large. The succession of important visits to Sweden potentially created an unfavourable image in Norway and Denmark, who after all had been loyal supporters of the allied cause. ${ }^{4}$ The FO had to advise the Air Ministry in July 1945 of the dangers of excessive contacts with a recent neutral, and as Warner said, 'the Swedes were not even very good neutrals and we certainly do not want to give the impression that we are all over thein'.5 British representatives were working actively to promote closer ties with Norway and Denmark,

\footnotetext{
${ }^{1}$ A personal account of the visit is found in Lionel H. Blaxell, Through the Hawse Pipe (privately printed memoirs, 1990), Imperial War Museum, London.

${ }^{2}$ Sutton-Pratt to Jerram, 29.10.1945, FO 371/48036.

${ }^{3}$ Ibid.; Had there been a war..., 133.

${ }^{4}$ Warner to Air Vice-Marshal W. F. Dickson, 19.7.1945, FO 371/48035.

${ }^{5}$ Ibid.
} 
especially militarily and politically. The Norwegian and Danish armed forces received equipment from Britain and took part in the occupation duties in Germany. ${ }^{1}$ Bevin had already said that equipping the Norwegians was clearly in the British interest for the long term and that 'their armed forces should as far as possible be linked by the use of common types of material' ${ }^{2}$ Close cooperation was also started between the social democratic party in Norway and Labour in Britain. ${ }^{3}$

Another problem with Sweden concerned personalities. From a British point of view, there still remained many 'guilty men' in the Swedish armed forces, who had showed their pro-German bias all too clearly during the war. ${ }^{4}$ This applied especially to the Swedish navy and army. General Douglas's attitude was met with scepticism in the FO. As G. M. Warr of the Northern Department put it, he 'is and always has been proGerman', and his more conciliatory attitude did not necessary imply that he was more cooperative than before. ${ }^{5}$

The problem was how to deal with these people. If the main aim was to have better ties with the Swedish armed forces and simultaneously pull Sweden into closer political and military relations with Britain, what should the British do about the pro-German element in Sweden? ${ }^{6}$ Among the British diplomatic representatives, there was a growing tendency to let 'bygones be bygones'. ${ }^{7}$ Yet, a policy of cold shouldering some

\footnotetext{
${ }^{1}$ Brief for Attlee, 21.6.1946, PREM 8/297, PRO.

2 Turner, Britain, the United States, and Scandinavian Security Problems 1945-49, 107.

${ }^{3}$ Udgaard, Great Power Politics and Norwegian Foreign Policy, 230 - 235. See also Denis Healey's memoirs for his close contacts with Norwegians, a country which he said was 'a twentieth-century equivalent of the ancient Greek city-state'. Denis Healey, The Time of my Life (London: Penguin, 1990), 209 - 210. On Scandinavian views of British socialism, Karl Molin, 'Winning the Peace: Vision and Disappointment in Nordic Security Policy, 1945-49', Henrik S. Nissen (ed.), Scandinavia during the Second World War (Minneapolis: The University of Minnesota Press, 1983), 325 - 328

${ }^{4}$ Jerram to FO, 3.9.1945, FO $371 / 48035$.

${ }^{5}$ Warr minute, 14.11.1945, FO 371/48036.

${ }^{6}$ Ewart minute, 18.9.1945, FO 371/48035.

${ }^{7}$ Jerram to FO, 3.9.1945, FO 371/48035.
} 
personalities might help to further British long term interests by 'teaching Sweden the salutary lesson that there are in fact bygones that still require forgetting' ${ }^{1}$ At the same time it could alienate a large part of the Swedish military and political establishment and would not help at all to build friendly relations as a whole. The choice was between necessity and principle: Swedish cooperation was needed to secure British influence in the north, but the wartime record could not easily be forgotten.

In 1945 and early 1946, the memory of the wartime information blackout of the British military attachés in Stockholm and Sweden's concessions to Germany still reinained strong. The concessions by the Swedes during the last months of the war did not improve this image as much as they might have wished. The army chiefs in particular were critical in their attitudes towards the Swedes. In early 1946 the COS decided to begin a policy of cold shouldering the pro-German element in the Swedish armed forces and actively to exert pressure to have them removed from important positions. ${ }^{2}$ The FO followed this line, but it was soon evident that the success of this policy depended entirely on the cooperation of the Swedish government. Also, the policy had little chance of success if it could not be coordinated with the Americans, who were cultivating contacts with the Swedes as well, especially on the civil aviation side. This contrasted with their wartime attitude, when the Swedes had complained that it was the Americans who were tougher and the British more 'understanding'. It was suspected that the reason for the American's relative kindness to the pro-German element in Sweden was that they were trying to integrate themselves in Sweden for commercial reasons. ${ }^{3}$

The chance of the COS policy succeeding was not very high. On the ground, lack of coordination persisted between different service departments and service attachés, and

\footnotetext{
${ }^{1}$ Ibid.

${ }^{2}$ FO to Stockholm, 25.1.1946, FO 371/56941.

${ }^{3}$ Sutton Pratt to director of military intelligence, War Office (WO), 4.2.1946. Warr minute, 18.2.1946, FO 371/56959.
} 
most important of all, Anglo-American cooperation was practically non-existent. ${ }^{1}$ Before long, it became also clear that the Swedish government was not willing to begin purges in the Swedish political and military establishment. Thus, in the end, the British had to come to terms with people they had previously disliked. The policy of trying to secure changes in the Swedish high command was too difficult to carry out and according to Warner from the Northern Department might have actually done more harm than good. If the British took this policy further, the Swedes might stop cooperating with them completely and turn to the Americans instead. ${ }^{2}$ As Jerram from Stockholm reminded, the list of German sympathisers in Sweden reached very high into the establishment, including the present social democratic minister of defence. It included large parts of the royal family and the court as well. ${ }^{3}$

When necessity overruled principle, a different approach to 'pro-German' Swedes was also needed. More evidence about these people began to filter in, suggesting that some of them, at least the most important of them, were not in fact 'anti-British', and if they had been 'pro-German', they were 'anti-Nazi' ${ }^{4}$ It was highlighted further, that even if they were 'pro-German', they were strongly 'anti-Russian' and therefore they would be 'glad to see Germany re-emerge as united factor, and even as a military entity in Central Europe'. 5 The FO was only too happy to see this muddled episode in Anglo-Swedish relations reaching its end.

After the British had dropped the idea of trying to eliminate German sympathisers from important positions in the Swedish armed forces in the spring 1946, there was more

\footnotetext{
${ }^{1}$ Jerram to Warner, 7.3.1946, Warner to Jerram, 21.2.1946, Jerram to Warner, 27.2.1946, FO $371 / 56941$.

${ }^{2}$ Warner to Jerram, 21.2.1946, FO 371/56941.

${ }^{3}$ Jerram to Warner, 27.2.1946, FO 371/56941.

${ }^{4}$ Sutton Pratt to WO, 2.2.1946. Warner to Jerram, 21.2.1946, FO 371/56941; Sutton Pratt to Jerram, 26.2.1946, FO 371/56970.

${ }^{5}$ Sutton Pratt to Jerram, 26.2.1946, FO 371/56970.
} 
room for developing service contacts. In May 1946 the COS, without consulting the FO, decided to upgrade Sweden's position in the categories relating to disclosing confidential technical military information and supply of equipment. Sweden was now in 'class B', which meant that it was on the same footing as Norway and Denmark. ${ }^{1}$ Exchanges between the air forces, such as visits of Swedish officers to Britain for training programs continued. ${ }^{2}$ The Swedes also proposed close cooperation between their own and the British aircraft industries, including exchange of secret technical and scientific information. The British obviously had more secrets to share than the Swedes did, but cooperation on this field would have given the British aircraft industry a virtual monopoly, free from all competition in the Swedish market. A firm hold of Swedish aircraft production would in the case of further Scandinavian defence coordination also have inade the Norwegian and Danish air forces dependent on the United Kingdom with considerable strategic advantages. ${ }^{3}$ From a strategic point of view the benefits were obvious, but politically these could be offset if Russian suspicions were aroused. ${ }^{4}$ These suspicions and a counterattack would almost certainly follow and the mood in the FO was that if anything 'very secret' was disclosed 'the Russians would be almost certain to find about it' ${ }^{5}$ In the event, this kind of amalgamation of the respective aviation industries did not take place, but nonetheless the first contract for the sale of 70 Vampire aircraft in 1946 to Sweden and the subsequent new contracts, began a period of close commercial contacts and technical cooperation, that lasted until the 1960s.

Relations with the Swedish military were mostly initiated on an unofficial level. It clearly indicated a beginning of a new era in the relations between the two countries, but

\footnotetext{
${ }^{1}$ Mr. Courtney (ADM) to Warr, 29.5.1946; Hankey to Jerram, 1.6.1946, FO 371/56941.

2 Nordenskiöld to Lord Tedder, 4.3.1947, 7.6.1947; Lord Tedder to Nordenskiöld 30.4.1947, 29.7.1947, AIR 8/1582, PRO.

${ }^{3}$ E. Haynes (Ministry of Supply) to Hoyer Millar (FO), 15.4.1946, FO 371/56954.

${ }^{4}$ Creswell (Service Liaison Department) minute 27.4.1946, FO 371/56954.

${ }^{5}$ Sutton Pratt to Jerram, 26.2.1946, FO 371/56970.
} 
the conclusions concerning the warming of relations on the military level in $1945-46$ cannot be taken too far. No military secrets of a first class nature were exchanged. The British offered no help of official nature to the Swedes. The political problems concerning Sweden's nonalignment and Soviet Union's suspicions about British moves in Scandinavia, countered any effective beginnings of military consultations between Britain and Sweden. Nevertheless, a channel was opened between service authorities in both countries, which could be used in a more conducive political climate.

In the meantime, FO policy was, before the strategic assessments of 1947 and the worsening international climate, that the British government took 'a much closer interest in Norway and Denmark than in Sweden because they are allies [sic], are closer to us and of somewhat greater direct strategic importance'. ${ }^{1}$ The official attitude towards Sweden was thus cooler. However, the flow of high level visitors, military and civilian, from Britain to Sweden increased steadily during the first half of 1946, leading Jerram in Stockholm to wonder whether the policy of coolness towards Sweden had been changed. ${ }^{2}$ The pull of the Swedish economy seemed too difficult to resist and for many in Britain Sweden seemed like an oasis in a Europe otherwise shattered by war and destruction. Among individual high level visitors and representatives of the armed forces were Treasury and Bank of England officials, different delegations studying various aspects of social services, town planning, industries, public broadcasting, agriculture etc. ${ }^{3}$ Both Robin Hankey from the Northern Department and Jerram in Stockholm sharply described the motives behind the visits as '[s]ilk stockings and schnapps', conducted by

\footnotetext{
${ }^{1}$ Hankey to Jerram, 1.6.1946, FO 371/56941. Eriksen \& Skodvin have stressed the British animosity towards Swedish neutrality after the war 1945-47. Their documentation, which is primarily from 1945 , does not show the change that took place in the period under discussion here. Eriksen \& Skodvin, 'Storbritannia, NATO og et skandinavisk forbund', 449 - 451.

${ }^{2}$ Jerram to Hankey, 15.4.1946, FO 371/56224; Jerram to Hankey 16.5.1946, FO 371/56941.

3 Jerram to Hankey, 15.4.1946, FO 371/56224.
} 
a British 'soup-ticket brigade'. ${ }^{1}$ The two-way traffic had nevertheless an important function from the commercial point of view, which was well understood by the economic experts in the FO and Treasury. This led Hugh Ellis-Rees from the Treasury to urge the Home Office to improve the facilities for more Swedish businessmen to visit Britain in the name of the export drive needed to secure Swedish raw material imports. ${ }^{2}$ The more or less spontaneous interaction at this level and 'the tremendous increase in official and cultural contact between the two countries' brought the wider public of the two countries closer together than they had been before the war. ${ }^{3}$ As a sign of Sweden's Western orientation, English replaced German in Swedish schools in 1946 as the first compulsory foreign language. ${ }^{4}$

Although the FO reassured Jerram that no major change in the official policy towards Sweden had occurred, relations on lower level seemed to live a life of their own. This created a situation in British foreign policy, that while high policy changed slowly, events below created pressures for change. While the general attitude of Sweden in different parts of the British government and central administration grew warmer in 1946 and while the military had abandoned their cold-shouldering policy and were now deliberately pursuing closer contacts, the FO had to consider the political implications. Denis Allen from the Northern Department minuted that 'as usual we are I think defining the policy ex post facto to fit the facts' and that the number of high level visits by British ministers was not part of any carefully thought out policy. ${ }^{5}$ In the end, the FO decided not to cut down the travelling of the 'soup ticket brigade', considering it relatively harmless in the current impasse in East-West relations. ${ }^{6}$

\footnotetext{
1 Jerram to Hankey, 16.5.1946, FO 371/56941.

${ }^{2}$ H. Ellis-Rees to H. H. C. Prestige (Home Office), 26.6.1945, FO 371/48035.

${ }^{3}$ Jerram to Hankey, 16.5.1946, FO 371/56941.

${ }^{4}$ Birger Steckzén, Svenskt och brittiskt. Sex essayer (Stockholm: Gebers, 1959), 61 - 62.

${ }^{5}$ Allen minute, 28.5.1946, FO371/56941.

${ }^{6}$ Hankey to Jerram, 1.6.1946, FO $371 / 56941$.
} 
The Swedish Foreign Ministry was not entirely happy with the highly publicised exchange of visitors and the growing interaction with the British either. Reflecting the 'indignation' among leading Swedes of Churchill's 'iron curtain' speech at Fulton in March 1946, the Swedish Foreign Ministry successfully disencouraged the Swedish section of the international writer's organisation Pen-Club from inviting Churchill to speak in its meeting in Stockholm. ${ }^{1}$ That Churchill's visits to Scandinavia as a whole were not, even if he was otherwise respected, particularly opportune at this point was seen at the same time in Norway, when the local communists criticised heavily a proposed visit by Churchill to meet King Haakon. The visit was postponed until 1948 and in his reply to the King, Churchill said he hoped to come within a year or so, 'when the situation might be much better, or perhaps much worse'. ${ }^{2}$

On the diplomatic level, new nuances began to appear in Britain's attitude towards Sweden. The official coolness continued to make way for a warmer relationship. When Hankey in June 1946 explained the new 'nuances' to Jerram, he referred to growing East-West tension: 'Thus it has in the last six months become apparent that the Union of Soviet Socialist Republics instead of being our friend and ally as we should have hoped, is out to make difficulties for us everywhere'. Hankey wrote that this made Britain less interested 'in the pure local significance of their [Sweden's] past attitude to the Germans'. ${ }^{3}$ New enemies created new friends, albeit slowly.

On the other hand, the British, in concert with the Swedes, wanted to avoid any moves that would promote great power competition or friction in Scandinavia. ${ }^{4}$ There existed a delicate balance in the region between the Western powers, Sweden, and the

\footnotetext{
1 On the views over Churchill's speech, Gunnar Hägglöf, Fredens Vägar (Stockholm: P.A. Norstedt \& Söners, 1973), 34 - 36; Ewart minute, 26.3.1946, FO 371/56941.

${ }^{2}$ Quoted in Grafström's diary, 1.7.1946.

${ }^{3}$ Hankey to Jerram, 1.6.1946, FO 371/56941.

${ }^{4}$ Hankey minute, 22.11.1946; Warner minute, 22.11.1946, FO 371/56959.
} 
Soviet Union. Soviet troops were withdrawn from Øst-Finnmark in September 1945 and from Bornholm by April 1946. The British, for their part, had no plans to establish military bases in Scandinavia in peacetime. ${ }^{1}$ Hankey wrote in November 1946 that it was not in the British interest to promote Anglo-Soviet competition in Scandinavia, as relatively little competition existed there at present. ${ }^{2}$ Before firm American commitment to the defence of Western Europe, the rising American interest could even be a potential threat to this balance. The situation needed careful handling as Hankey elaborated the position further: 'Sweden is now in the front line along the great arc which divides the Soviet from the outside world and it has diplomatic importance which it has not had before in peacetime for a great many years'.3

Although the official government line allowed little room for doubts, not everybody in Sweden was in favour of an isolationist policy based on nonalignment. From a strategic point of view, the disappearance of Germany as a counterbalance to Soviet Union in the Baltic region posed a new threat to Sweden. The military saw this most clearly and this was largely behind their attempts to foster closer relations with the British, who felt the same about the Swedes. Nevertheless, the main problem for the Swedish military leaders in their attempts to establish links with the other Scandinavian or Western powers was official Swedish foreign policy. At home, the Swedish military found support in the political right and among the senior officials in the Foreign Ministry. ${ }^{4}$ Against the powerful hegemony of the social democrats and isolationists, they needed all the support they could get, if they planned to change the direction of Swedish security policy. The contacts with the British must be seen against this background. Help

\footnotetext{
${ }^{1}$ Eriksen \& Skodvin, 'Storbritannia, NATO og et skandinavisk forbund', 439 - 441; Knut Einar Eriksen, Storbritannia og baseproblematikken $i$ Norden, 27.

${ }^{2}$ Hankey minute, 22.11.1946, FO 371/56959.

${ }^{3}$ Ibid.

${ }^{4}$ Molin, Omstridd neutralitet, $30-45$.
} 
from abroad was needed, first to orientate Swedish security policy more firmly to look to the West and then, possibly, to enlist concrete support.

In this picture, Britain was well placed as a collaborator. The intentions of the Americans in the postwar situation were still unknown and Britain had traditionally shown more interest in Scandinavia than any other Western power, besides Germany. Now that German influence had disappeared, it left only Britain in the picture. In 194546 the British were using this situation to build up closer relations with Sweden as a part of a wider policy of consolidating Western Europe. Nevertheless, even if important military leaders and some Swedish politicians after the war seemed well disposed towards Britain and in favour of closer cooperation, this did not solve the main problems. The tension, within and outside Sweden concerning its neutrality policy, was a strong undercurrent beneath the events leading to the cold war in northern Europe, and indeed during the first years of it.

The prospect of a Scandinavian bloc

By early 1946, the resumption of Sweden's contacts with the British led to a critical response from the Soviet Union. This reflected the general worsening of relations between the Soviet Union and the West, made only more visible after Churchill's Fulton speech. The flow of British visitors led the Soviets to inquire whether Sweden was changing its political course. ${ }^{1}$ The Soviet press devoted more critical attention to Sweden and Scandinavia. Sweden in particular received considerable criticism in Pravda on 4th February 1946 in an article that attacked ideas of a Swedish led Nordic bloc. ${ }^{2}$ In British

\footnotetext{
${ }^{1}$ Jerram to Hankey, 16.5.1946, FO 371/56941.

${ }^{2}$ Roberts to FO, 7.2.1946, FO 371/56222.
} 
eyes, the Soviet Union seemed to be following a traditional Russian policy, which since the times of Peter the Great, and earlier had concentrated to prevent Sweden developing into a major northern European power. On another front the Soviet Union played up Norway. In contrast to Sweden, there was a steady stream of publicity favourable to Norway and closer cultural relations were encouraged. The most important of all was the Soviet support for the nomination of Trygve Lie as secretary general of the United Nations. ${ }^{1}$ A wedge was being driven between the Scandinavian countries.

The Swedes tried to reassure the Russians that recent meetings of the Scandinavian foreign ministers were not intended to form any Scandinavian bloc, and the cooperation that was initiated between the respective governments was not political or military, but on the level of economic and cultural relations. It was also made known to the British that Undén put in private his case even more bluntly to the Soviet representative in Stockholm and said that Scandinavian cooperation was going to continue whatever the Russians might think. ${ }^{2}$

On another level of Scandinavian cooperation, Russian suspicions were better founded. From discussions with Sven Andersson, secretary of the Swedish Social Democratic Party, the British Labour Attaché G. N. Lamming formed the view that the Swedish social democrats were genuinely interested in creating a some kind of anticommunist bloc from the social democratic and social democrat controlled trade union movements in Scandinavia. The Scandinavian social democratic bloc would eventually then form a common front with its Western European counterparts, especially in Belgium, Holland and Britain. ${ }^{3}$ In the final analysis, a link with Britain on this level, and having the social democrats holding governmental power in many countries, would have meant a thinly disguised anti-Soviet front.

\footnotetext{
1 Ibid.

2 Jerram to FO, 2.4.1946, FO 371/56222.

${ }^{3}$ G. N. Lamming's report, 25.2.1946, FO 371/56222.
} 
But all these indications of closer Scandinavian cooperation had little potential compared to what began to develop later in 1946. Various authors have pointed out that exploratory talks on Scandinavian defence cooperation started well before the official announcement in the spring of $1948 .{ }^{1}$ There has been some variance in the interpretations of how far reaching these conversations between military representatives were, but the British impression from the beginning was that they aimed at real and effective defence coordination. $^{2}$

The first traces of tentative Scandinavian defence cooperation in the British records can be found as early as in November 1945. General Nordenskiöld informed the British representative then that 'he had obtained the permission of the minister of defence to invite the Chiefs of the Norwegian and Danish Air Forces to pay official visits to him in Stockholm' ${ }^{3}$ The visits were camouflaged as courtesy visits only, but the real purpose was to discuss standardisation of air force equipment, purchases from abroad and 'to discuss plans for mutual aid'. 'At this stage the British were still apprehensive lest the Russians found out of such plans and hoped the Swedes would not overstep the boundaries of discretion.

Further evidence of inter-Scandinavian talks appeared in late August and September 1946, when the FO was informed of a meeting between high military commanders from Denmark, Norway and Sweden to discuss a common defence plan for Scandinavia. Hankey minuted on these news: 'This is a remarkable tribute to Mr. Molotov's

\footnotetext{
${ }^{1}$ Petersen, Britain, the United States and Scandinavian Defence, 2 - 11; Eriksen \& Skodvin, 'Storbritannia, NATO og et skandinavisk forbund', 437 - 511. Other accounts of the defence talks 1946-47 are found in Nevakivi, 'Scandinavian Talks on Military Cooperation in 1946-1947', 165 - 175; Turner, Britain, the United States, and Scandinavian Security Problems, 110 - 123.

${ }^{2}$ In a pioneering study by Magne Skodvin, the conclusion was that these talks were merely tentative, investigatory and at the technical level. Skodvin, Norden eller NATO?, $57-58$. The British documentation in FO 371/65961 indicates a more serious attitude, although the talks had not reached very far by early 1947.

${ }^{3}$ Air attaché R. B. Maycock to Jerram, 2.11.1945, FO 371/56954.

${ }^{4}$ Ibid.
} 
diplomacy!' The British mission in Stockholm suggested that Britain should make the possible bloc dependent on Britain by making sure that all three countries used the same types of armaments, and not to give the Americans 'a direct interest close to the present line of East-West cleavage by letting them act as a source of supply to Sweden'?

While the diplomatic climate between Britain and Sweden was warming up in late 1946, the discussions about possible Scandinavian defence cooperation between Norwegian, Danish and Swedish military commanders continued. The initiative now came from the Danish Naval Staff, which also confidentially kept the British service departments and the FO informed of the developments. ${ }^{3}$ The Danes especially were keen to ascertain what the British attitude towards the talks was. With this in mind, the Danish commander in chief, Admiral Vedel, came to Britain in May 1947 for secret talks on Scandinavian defence problems. ${ }^{4}$ While it was acknowledged in London that the conversations between the Scandinavian representatives were still at a very early stage, it soon became necessary to define Britain's position towards a possible Scandinavian bloc and its implications in British defence strategy and in East-West relations.

Both the FO and the COS had to clarify their positions. From both political and strategic points of view it needed to be decided on a high level in Britain whether Scandinavian defence cooperation was in British interests, and what Britain's role should be. The initial response from the director of naval intelligence to the plans of common Scandinavian defence was favourable. He saw that this 'could not but be to our advantage'.5 From June 1946 onwards the British military had already encouraged their Scandinavian counterparts to plan common defence, particularly through their contacts

\footnotetext{
${ }^{1}$ Rose (Copenhagen) to Hankey, 18.9.1946; Hankey minute, 26.9.1946, FO 371/56222.

${ }^{2}$ Stockholm chancery to FO, 29.8.1946, FO 371/56941.

${ }^{3}$ Hankey minute, 29.5.1947, FO 371/65961.

${ }^{4}$ First sea lord minute, 29.5.1947, ADM 205/67; Hankey to Sargent, 29.5.1947, FO $371 / 65961$.

${ }^{s}$ Collier to Attlee, 19.12.1946, FO 371/65961.
} 
in the Danish naval intelligence. ${ }^{1}$

While strategic questions were left to the COS, the views of the political implications of these plans were divergent among the British diplomatic representatives. The existing Inood in the FO was inclined to accept the military's views, but the main dissenting voice came from Oslo. The British ambassador in Oslo, Sir Laurence Collier who was well known for his anti-Swedish views - as well as for his undoubted expertise in Scandinavian affairs - held that as Sweden was the most powerful Scandinavian country, a defence bloc would in practice mean 'collaboration under Swedish leadership'. As Sweden was less likely to follow a Western lead in its foreign policy, a Swedish led Scandinavian bloc would also mean that Norway and Denmark would have to take more neutralist attitudes in their foreign policy, meaning more detached relations with Britain. 'Appeasement is Sweden's usual policy towards her strongest neighbour: she appeased Germany during the last war and she is now appeasing the Soviet Union', Collier continued, and 'though a Nordic bloc under Swedish leadership would doubtless be reluctant to take extreme measures against British interests at the behest of the Soviet Government, there are various steps which it might be willing to take and which would be less likely to be taken if it were not in existence'. As far as Norway was concerned, it was clear to Collier that to encourage Scandinavian defence collaboration was not in British interests, because 'this is only likely to be developed in circumstances which would render it to the advantage of the potential enemies of Great Britain' ${ }^{2}$

Collier had deeply rooted suspicions about Sweden and he clearly spoke against a separate Scandinavian bloc. It could only be beneficial for Britain if the British connection with Norway and Denmark was solid and permanent enough to counter Swedish influence. While hanging on to the wartime anti-Swedish atmosphere in the

\footnotetext{
1 Turner, Britain, the United States, and Scandinavian Security Problems, 105 - 107, 116.

${ }^{2}$ Collier to Attlee, 19.12.1946, FO 371/65961.
} 
Northern Department during the Blitz, which his colleagues had or were in process of being overcome, he also reflected Norwegian suspicions. At this point, some of the British policy makers even thought that the Norwegian and Swedish military were barely on speaking terms with each other due to the events during the war, and that the Danes were painstakingly trying to mediate between the two in their high level discussions. ${ }^{1}$ This was not the case, but rumours like that fuelled the suspicions represented by Collier.

However, both the ministers in Stockholm and Copenhagen opposed Collier's reasoning. Randall from Copenhagen considered that it was 'important for us to encourage any development which will give the two materially weaker powers strength to uphold that neutrality and to resist any demands on them'. Britain was not in a position to give Denmark such material help that the Swedes might be able to provide. Sweden's participation in common Scandinavian defence involved in Randall's view 'a certain risk', but the alternative - no defence cooperation at all - was far worse. A common defence, from a Danish point of view, would stiffen the country's will to resist aggression, which would without some kind of external help be practically impossible. ${ }^{2}$ He advised the British government to keep themselves informed of the talks and 'to show discreet sympathy with them' ${ }^{3}$

These views were echoed in the advice from Stockholm. Jerram said that the Swedes were unlikely willing to engage in a war against the West. He could not see how the talks, in as far as they were unknown to the Russians, could lead to an unfavourable situation in the north from Britain's point of view. He even suggested that a possible Scandinavian bloc 'might be acceptable both to Russia and to Great Britain for opposite reasons: the Soviet Government might prefer a Scandinavia which was less directly under the Anglo-Saxon influence while Great Britain and America might prefer to see a

\footnotetext{
${ }^{1}$ Hankey minute, 29.5.1947, FO 371/65961.

${ }^{2}$ Randall to Bevin, 4.2.1947, FO 371/65961.

${ }^{3}$ Hankey to Group Captain C. C. Stapleton (Cabinet Offices), 24.4.1947, FO 371/65961.
} 
Scandinavia which had greater inherent powers of resistance'. 'The chances to get this kind of alliance through in the Swedish parliament were, nevertheless, not very good. This would be the case at least until both Norway and Denmark had built up their defences to something comparable to Sweden's. He suggested the British government continue to foster good relations with the Swedish armed forces and show them how it would be in their interest to align themselves, either actively or passively, on the British side in any future war. The British should encourage secret planning between the Scandinavian staffs, as long as it would not evoke Russian suspicions that the British were discussing anti-Russian plans with the Swedes. ${ }^{2}$

The conclusion reached in the FO concerning a possible Scandinavian military bloc was in principle favourable. Collier's warnings were overruled. As the situation was still at such a preliminary stage, and as the Scandinavian governments were unlikely to come out with their plans in the open in their fear of the Soviet Union, Britain clearly stood on the gaining side. Collier's suspicions of Sweden were no longer shared in London in the same way, as necessity had already in 1946 overruled principle. Sweden had no choice other than to seek good relations with the Soviet Union, but its basic Western orientation was seen as strong enough to counter possible risks. In Hankey's views the Swedish government had 'not carried appeasement to the point of sacrificing their principles, as they did vis-à-vis of Germany in the war'. ${ }^{3}$ This picture of Sweden was further enhanced by the notion that the Swedish military were strongly in favour of links with the West. As long as Russian suspicions were not evoked, and thus a possible increase in pressure towards Scandinavia, the plans were given a green light in London.

The political side being cleared, the military chiefs made their conclusions from the strategic point of view. At this stage British strategy stood on three pillars: the defence

\footnotetext{
${ }^{1}$ Ibid.

${ }^{2}$ Ibid.

${ }^{3}$ Ibid.
} 
of the United Kingdom and its development as a base for an offensive, the maintenance of its sea communications and the retention of the Middle East. ${ }^{1}$ The Cabinet endorsed the Three Pillars strategy in January 1947 and it remained the basis of British defence policy until 1952. The balance between Britain's imperial and European defence was difficult to find. The COS thought that if any of the pillars collapsed, the whole concept would go with it. ${ }^{2}$ The main dispute during this period was about Britain's withdrawal from its commitments in the Middle East, which Attlee proposed and Bevin, the FO and the COS strongly opposed, and about the role continental Europe should be given in British defence. The debate about Britain's strategic priorities was set against a very tight budgetary stringency, which limited Britain's capabilities for expensive overseas defence commitments.

In their assessment of the strategic position of the British Commonwealth from April 1946, the COS had divided British defence into main support areas and into additional areas of strategic importance. The main support areas were the UK, the American continent, Southern Africa and Australia. Their conclusion was that British defence could not in time of peace prepare to defend these areas only. Britain should also establish and maintain its influence in 'other areas of strategic importance since we must assume that, if we do not, our influence will be supplanted by that of Russia'. ${ }^{3}$ The other areas were Western Europe including Scandinavia, the Iberian Peninsula and North West Africa, the Middle East, India and South East Asia ${ }^{4}$ This required significant investment in military capabilities and building of cooperation with countries within these areas.

${ }^{1}$ Cabinet Minutes, Confidential Annex, 15.1.1947, CM(47)6, CAB 128/11, PRO. Ritchie Ovendale (ed.), British Defence Policy since 1945 (Manchester: Manchester University Press, 1994), 36 - 37.

${ }^{2}$ COS minutes, COS(47)9, 13.1.1947, DEFE 4/1.

${ }^{3}$ COS report on the Strategic Position of the British Commonwealth, 2.4.1946, DO(46)47, CAB 131/2; Ovendale, British Defence Policy since 1945, 24 - 28.

${ }^{4}$ Ibid. 
The document prepared by the Joint Planning Staff (JPS) in June 1947 is a very illuminating description of Scandinavia's increased weight in wider British strategic thinking. ${ }^{1}$ On its background were the debates between the COS and the Cabinet, Attlee in particular, over the priorities in British imperial strategy. Already in January 1947 Attlee had pointed out the importance of continental Europe to British security and said:

If it was considered essential to support Turkey, Persia and Iraq as defensive bastions to our interests in the Middle East, surely it was of equal importance to encourage a strong region of defence in such countries as the Low Countries, Scandinavia and France, owing to their close proximity to the United Kingdom. ${ }^{2}$

Attlee was well ahead of most of his military advisors in stressing the significance to British security of the geographically closer Europe, and the JPS's assessment of Britain's strategic interest in Scandinavia was not entirely out of step with this. But if not turning the centre of gravity in COS strategic thinking to the north, it nonetheless provided the background against which Britain's overall cold war interests in Scandinavia were to be interpreted long into the future as well. Put simply, the message was that Britain had a considerable, even unprecedented, strategic interest in Scandinavia in peacetime and in the way the region's defence was arranged. The fact that the British were themselves unwilling to assume defence commitments in the north, which Mats Berdal among others has stressed, in no way reduced the region's weight in British strategic thinking. ${ }^{3}$ The JPS said that 'by virtue of their geographical position, Norway,

\footnotetext{
${ }^{1}$ The most extensive earlier accounts of Scandinavia's position in British postwar military strategy are in Villaume, Allieret med forbehold, 120 - 144; and Berdal, The United States, Norway and the Cold War, 9 - 13. Berdal stresses the limited character of British commitments to the defence of northern Europe, while Villaume puts slightly more weight on Scandinavia in British defence planning. On US strategy see also the impressive study by Rolf Tamnes, The United States and the Cold War in the High North.

${ }^{2}$ COS minutes, COS(47)9, 13.1.1947, DEFE 4/1.

${ }^{3}$ Berdal, The United States, Norway and the Cold War, $9-11$.
} 
Sweden and Denmark would assume great strategic importance in a war between the Western Powers and Russia. Both sides would gain considerable advantages by occupying these countries and would, therefore, at the least, be anxious to deny them to the enemy ... We regard the integrity of Scandinavia in the event of war with Russia as almost as important as the integrity of France, Holland and Belgium'. ${ }^{1}$ This integrity was especially important in the early stages of a war. The value of Scandinavia for the Western powers was in the possibility of having advanced air bases which would halve the distance to the Soviet Union and put them in a favourable position if the need arose to attack Soviet troops and communications elsewhere in Europe. Western early warning systems would be greatly improved if Western air defences could start over Scandinavia, instead of further West. Naval operations in northern waters and in the Baltic would be more easily covered. Lastly, more manpower, industrial and natural resources would be available.

On the other side of the coin, the value of Scandinavia to Russia was in the way it could gain control of the exits from the Baltic to open seas. From Norwegian ports it could operate in the Atlantic to attack Britain and its north Atlantic communications. Like the Western powers, the Russians would gain air bases from which to strike Britain and start its own air defences. Raw materials and industries could be used to help the Soviet war effort.

As a bloc, Scandinavia's power of resistance would be 'somewhat increased', a phrase that in its vagueness was well attuned with Britain's general European strategy. But as a sign that any added strength, however marginal, would have a relatively high return in an otherwise hopeless strategic situation, the JPS said that the effort to overcome this resistance would be an additional drain on Russian resources, and 'by its delaying effect on Russian progress into Western Europe in the initial stages of hostilities, might have

\footnotetext{
1 JPS report 'Scandinavian defence - strategic considerations', JP(47)56 (FINAL), 4.6.1947, DEFE 4/4.
} 
far reaching effects on the course of the war'. ${ }^{1}$ The JPS did not believe in the arguments put forward by Collier, that a Scandinavian bloc would lean towards the Soviet Union instead of the West. Instead they thought Sweden might 'at the very worst' only succeed in persuading the bloc to adopt neutrality.

The crucial issue was, however, that the COS did not believe a Scandinavian bloc would be militarily viable without external help. As they said, 'the Scandinavian countries realise this and are therefore unlikely to be willing to set up a common defence organisation unless they receive specific guarantees of immediate and effective support, including military aid, from the Western powers'. ${ }^{2}$ On this score, two problems existed: the political difficulties among the Scandinavian governments of taking steps to align theinselves militarily with the West and secondly, where would that help come from. Britain did not have the considerable resources needed, as it was already militarily overstretched, and the attitude of the Americans to the future defence problems of Europe was by this stage still very uncertain. Despite this, Britain could not let this opportunity slip by and encouragement was needed if the Scandinavians were to go ahead. A Scandinavian bloc, tacitly backed by Britain would solve two problems simultaneously: the political one vis-à-vis the Soviet Union and with Scandinavian electorates educated to a policy of neutrality and secondly, of limited British resources.

What then was really needed? At first sight it seemed that the Russians would face considerable problems in overrunning Norway and Sweden, because of the technical requirements needed in operations to cross the Baltic or attack near the arctic circle. The terrain and the climate favoured defence. This had most clearly been shown in Stalin's near disastrous Finland campaign in 1939-40. 'It might be', the COS concluded, 'that an effective defence of these two countries, or at least a valuable and perhaps decisive delay

\footnotetext{
1 Ibid.

2 Ibid.
} 
in Russian plans for an advance into Western Europe could be achieved with support from British or U.S. air forces and carrier forces'. ${ }^{1}$ The case of Denmark was different, but it depended more on what a wider Western European defence system would look like.

The COS said that it was apparently only possible to create coordinated Scandinavian defence under cover of secrecy, for fear of Soviet reactions. Nevertheless, a tacit approval of the Scandinavian governments was needed. Hankey saw secrecy to be very important at this stage, because 'the Russians if they got to hear of it would be likely to turn the heat on and this might frighten the politicians in all three countries into preventing any further inter-service contacts taking place'.$^{2}$ Even if the Russians reacted, the COS did not consider it disastrous, because Russians would 'do little more than offer objections and threats' and moreover the open creation of a Scandinavian bloc 'might have some slight deterrent effect upon Russian expansionism'. In the end, it was 'better to have a covert bloc than no bloc at all'. ${ }^{3}$ The COS was not as sensitive to political considerations as the FO. That was an indication primarily of their own departmental concerns, but also about their views of the right policy towards the Soviet Union, against whom the COS had already been speaking in tougher terms.

From a COS point of view, the prospect of having a Scandinavian bloc in the north was attractive. Nevertheless, the plan was seen as worth while to the Scandinavian countries themselves only if they could be sure of armed backing by the Western powers. COS suggested that the British contribution should be limited to covert advice on military 1natters. The question of supplying a Scandinavian bloc would be best resolved by letting the already well-developed Swedish armaments industry produce British arms under licence. By doing this, a Scandinavian bloc, backed by Britain, would not drain British

\footnotetext{
${ }^{1}$ Ibid.

${ }^{2}$ Hankey to Sargent, 29.5.1947, FO 371/65961.

${ }^{3}$ JPS report, 4.6.1947, DEFE 4/4.
} 
resources and manpower. In war, air power could be used to defend the region and to attack important targets in Soviet Union and Central Europe. Thus, the front line of any future war would be pushed considerably eastwards, a welcome prospect in an otherwise almost impossible strategic situation in Europe. The support of the COS for the talks to go ahead was not surprising. As a result of the considerations of the COS and the FO, the British representatives were authorised to inform the Scandinavian governments in August 1947, that the British attitude was positive towards Scandinavian defence cooperation, but because of the Soviet Union's suspicions this should be conducted secretly. ${ }^{1}$

The American view on a Scandinavian bloc was not as enthusiastic as the British. This reflected the low priority given to Scandinavia, except Greenland and Iceland, in American global strategy in $1945-47 .^{2}$ In the State Department the Division of Northern European Affairs said that the formation of a Scandinavian bloc 'would have disastrous results for Finland since the Soviets would unquestionably regard such a bloc as hostile and, therefore take steps to speed up the complete absorption of Finland as a countermeasure'. ${ }^{3}$ No corresponding appreciation of Finland's position existed in London, thus showing the Americans' at this stage more idealistically coloured view of the Nordic region in the growing East-West tension. However, when later in 1948 the Swedes used the same argument against their participation in NATO, it had very little effect on the Americans, who by then had defined their aims in the region. ${ }^{4}$

' Turner, Britain, the United States, and Scandinavian Security Problems, 121.

2 On the importance of Greenland for example, Byrnes to the Legation in Denmark, 2.1.1947, Foreign Relations of the United States (FRUS) 1947, Vol III: The British Commonwealth; Europe (Washington: Government Printing Office, 1972), 657 - 658; Memorandum of conversation between George C. Marshall and Henrik de Kauffmann (Danish ambassador in Washington), 17.6.1947, FRUS 1947, Vol III, $669-671$. See also the report by the Danish Institute of International Affairs, Greenland during the Cold War. Danish and American Security Policy 1945-68 (Copenhagen: DUPI, 1997).

${ }^{3}$ Lundestad, America, Scandinavia, and the Cold War, 88.

${ }^{4}$ Ibid. 
As seen from Washington, Scandinavia was clearly regarded as of more interest to Britain than to the US. During and immediately after the war the Americans in most issues followed the lead of the British. As in the whole of Western Europe, the Americans generally assumed that the British would play a more important role. ${ }^{1}$ Geir Lundestad's thesis is that the US generally showed little interest towards Scandinavia compared to the British in 1945-47, but that this interest rose from late 1947. Moreover, the relatively indifferent attitude in the US towards neutrality, changed from 1947 onwards to a very hostile attitude. By the autumn of 1947, the Americans demanded Western Europe stand up and be counted in the struggle against communism. ${ }^{2}$ This developnent in US thinking was precisely the mirror-image of what happened in Britain, where apprehensions of Sweden's official policy of neutrality were being replaced by a more understanding and benevolent approach, aiming at influencing the content, but not necessarily the outward appearance of Sweden's policy.

The Soviet view on Scandinavian defence cooperation was hostile from the start. Besides Soviet criticism of Scandinavian cooperation in other fields, such as the idea of a Scandinavian customs union that was launched in the summer of 1947 , the most significant sign of Soviet suspicions came in November 1946, when Soviet Deputy Foreign Commissar V. G. Dekanozov complained to the Danish Minister in Moscow that 'military political conferences were taking place in Copenhagen between Danish, Swedish and British officers'. ${ }^{3}$ Whether this was a random shot or based on intelligence was impossible to tell, as the Soviet statement was inaccurate, but the assumption in Scandinavia and in Britain from then on had to be that the Soviet government was aware

\footnotetext{
${ }^{1}$ Ibid., $43-44$.

${ }^{2}$ Ibid., 95.

${ }^{3}$ Petersen, Britain, the United States and Scandinavian Defence, 3. This complaint took long to reach British ears, or indeed the Danish Foreign Ministry, ibid; Capt. Derek Wyburd (Copenhagen) to director of naval intelligence, 24.2.1947, FO 371/6596; Jerram to Bevin, 5.9.1947, FO 371/65985.
} 
that a defence union was on the cards. ${ }^{1}$ This did not, however, discourage the Scandinavians from proceeding in their discussions, and the Swedish defence minister told Jerram in Stockholm in November 1947 that the talks continued, with the government's tacit approval. ${ }^{2}$

During the period towards the cold war 1945-47, the importance of Scandinavia to Britain rose considerably. From a strategic viewpoint, technological developments in air warfare and the scenario of a possible future war with the Soviet Union increased Scandinavia's strategic importance. Also the tightening Soviet grip over Eastern Europe brought into focus Scandinavia, which bordered the emerging Soviet bloc, but was still independent. ${ }^{3}$ Especially changes in Finland's position could potentially influence the overall balance, which needed constant watching. The problem was to find the best means to consolidate Scandinavia both politically and militarily. In this project a solution to the problem of Sweden's aloofness was essential. From 1947 onwards the defence dimension in Anglo-Swedish relations became inore central, alongside with practical steps towards economic cooperation among the Western European nations, including Sweden.

By 1947, there still existed uncertainties about both Britain's position in postwar Europe and about the future outlook of great power relations. Some future trends were nevertheless already discernible. The Americans were showing an increasing interest in the political developments on the continent, but the precise significance of this involvement was unclear. A negative perception of Soviet intentions was crystallised in London in 1946. In Britain's policy towards Scandinavia the main problem was pinned down to Sweden's future political orientation. As a result, Britain began to develop closer relations with Sweden on the basis of ground-level interaction among the military; and on the commercial and diplomatic levels. These contacts soon brought home the fact that

\footnotetext{
${ }^{1}$ Nevakivi, 'Scandinavian Talks on Military Cooperation in 1946-1947', 165 - 175.

${ }^{2}$ Ibid.

${ }^{3}$ Lundestad, America, Scandinavia, and the Cold War, 85.
} 
Britain's Scandinavian dilemma could only be solved in concert with the Swedes. As the cold war intensified in 1947, the urgency of this problem increased but became also more complicated, when both the Soviet Union and the US stepped up their involvement in the region. 


\section{Trade, Economic CoOperation AND Foreign Policy, 1945-48}

While the British military planners became more and more interested in questions of Scandinavian strategy in 1946-47, the period of economic reconstruction also heightened Britain's traditional economic concerns in its relationship with Sweden. The FO was not only preoccupied by the political and strategic conditions for a modus vivendi with a militarily nonaligned Sweden in a worsening international climate, but pondered on the possibilities and problems that were involved in the relatively high degree of economic interdependence between the two countries. In the difficult economic conditions of the first postwar years, economic influences on British policy towards Sweden became increasingly acute. Whereas in strategic questions the role of the COS was central, in questions of trade, financial problems and economic cooperation, the economic departments, the Treasury and the Board of Trade were closely involved in policymaking as well. This chapter discusses economic dimensions in Anglo-Swedish relations and the linkages between foreign policy, economic cooperation and international trade from the resumption of peacetime trading to the formation of the Organisation of European Economic Cooperation (OEEC) in 1948.

\section{A double-edged sword}

On 21 of July 1947 Jerram wrote to Bevin from Stockholm:

Twelve months ago the political barometer seemed set fair as far Sweden was concerned. Most other countries were endeavouring, more or less painfully, to recover from occupation or the scars of war; Swedish larders were full and the Swedish krona seemed secure; and Sweden was comfortably settling down to 
preserve her standard of living in an impoverished world. ${ }^{1}$

But the past year had seen a darkening of the skies in Sweden as well as in Britain. EastWest relations had worsened, foreign currency reserves were vanishing, in Sweden inflation was going up and the change of political leadership after the death of Per Albin Hansson to the relatively unknown Tage Erlander had increased the feeling of insecurity in the country. The first secret talks about possible Scandinavian defence cooperation brought no visible changes in 1947. Like the general international political and economic situation, the climate was uncertain. Initial postwar optimism was disappearing everywhere and suspicion of the Soviet Union was on the increase in Sweden as well. ${ }^{2}$

Despite these developments, the Scandinavians were still very reluctant to follow the British into closer Western cooperation, even though British designs were vague. The Swedes in particular were firmly embedded in their policy of nonalignment. Other, 'practical arrangements', as the FO officials preferred to call it, were needed to place them on the right side in the emerging East-West division. What these 'practical arrangements' entailed, was that instead of an open association or alliance, they could also be integrated to the Western group of nations by alternative routes, such as regular contacts and consultations on the political level, military-technical cooperation and economic links.

In the search for possible 'practical arrangements', different aspects of policy became less easily distinguishable from each other. Hence, economic cooperation, arising from clearly identifiable economic interests, also became in British Scandinavian policy entangled with the general policy of consolidation of cooperation among the Westerr powers. If the Scandinavian countries, especially Sweden, wished to maintain thei nonaligned policy and stay away from the possible divisions between the great powers

\footnotetext{
${ }^{1}$ Jerram to Bevin, 21.7.1947, FO 371/66506.

${ }^{2}$ Ibid.
} 
it seemed that one of the more promising routes for improved and closer relations would be an economic one, coupled with increased ground-level interaction, such as took place among the military establishments of the different countries.

By 1948 the British could follow a strong American lead in the economic consolidation of Western Europe in the form of the European Recovery Program (ERP), launched after Secretary of State George C. Marshall's Harvard speech in June 1947. American dollars proved to be needed to achieve the necessary pulling power, in particular with Sweden, to establish closer institutional links with the West. Despite this, the British had a particular role to play and had their own interests in this sphere as well.

British interest in including the Scandinavians in the ERP was not only motivated by the general political interest in having them taking the right side in the emerging EastWest divide. What, among other things, made the Anglo-Scandinavian relationship different from the US-Scandinavian one, was the prominence of economic concerns in Britain. Besides being concerned with the political and strategic outlook of Scandinavia, the British were preoccupied in establishing Scandinavia as a part of the British economy. What complicated the picture, was that this project aiming at economic hegemony was mixed with other concerns arising from the cold war and from the perceived threat from the Soviet Union. These two goals blended in the work of the OEEC, which, as seen from the perspective of Anglo-Scandinavian relations, was as much a part of the cold war as of European economic reconstruction.

On the trade side, the link between the cold war and Britain's foreign economic policy in Scandinavia was indirect. The Soviet Union neither posed nor was thought to pose a serious economic threat to Britain in Scandinavia. The real challenges came from a longterm prospect of the revival of German competition, the traditional economic rival for Scandinavian markets and raw materials, and to a lesser extent, from the US. In actual trade policy the cold war had only an indirect bearing, in as much as the internal political 
cohesion of the West was thought to increase with higher economic interdependence and by developing ground level links on different levels of everyday life. In a more limited way, as the cold war went on, questions of limiting East-West trade in certain strategic goods through the US led Coordinating Committee's (COCOM) embargo policies, did make the cold war an economic phenomenon too, but this aspect was of lesser significance in British policy towards Sweden. ${ }^{1}$

Where the cold war had direct relevance was when institutional forms of economic cooperation were used to foster political goals, such as, which is argued here, in the OEEC to provide an institutional link between a militarily nonaligned Sweden and an increasingly cohesive West. The Anglo-Scandinavian Economic Committee (Uniscan), founded in January 1950 will be seen against this background. Its economic work was, on the British side, conditioned and motivated by political aims, such as the hope for further inter-Scandinavian cooperation and Sweden's integration to the West, preferably into the British sphere and in harmony with British interests.

That the Anglo-Swedish economic relationship could be a double-edged sword, was seen in the way that economic necessities and interdependence limited Britain's political leverage over Sweden, as its goodwill was of great importance for Britain's economic position in Europe. If economic cooperation increased the ways by which Sweden could be included as a part of the West, its actual material significance and the bargaining power it provided the Swedes with, could define and limit the ways in which this inclusion could take place. The need to maintain good relations with Sweden in the

\footnotetext{
${ }^{1}$ Gunnar Adler-Karlsson, Western Economic Warfare 1947-1967. A Case Study in Foreign Economic Policy (Uppsala: Almqvist \& Wiksell, 1968) is a classic work. On Swedish policy see Karlsson, Handelspolitik eller politisk handling. British policy towards East-West trade was connected to Britain's overall Swedish policy in as much as Britain served as a buffer between the US demands and European interests. See further Vibeke Sørensen, 'Economic Recovery versus Containment: The Anglo-American Controversy over East-West Trade, 1947-51', Cooperation and Conflict, Vol. 24, No. 1 (1989), 69 - 97.
} 
economic sphere made many leading British businessmen sympathetic to Sweden's policy of neutrality. In the City, and as far as commercial interests in general were concerned, there were many who thought that an open military association with the Western powers was not in Sweden's best interest. ${ }^{1}$

In economic diplomacy, the British had few good cards in their hand. Hence, the Swedes, with their even more limited economic leverage over the British, might be able to maintain their politico-military neutrality, a situation not unlike that with Germany during the Second World War. How this would affect the US policy depended to a great extent on the influence the British would have in Washington in persuading the Americans to adopt a line that was in harmony with the multiplicity of British interests in Sweden.

Underlying political aims were the economic realities that made it necessary for Britain to secure as good a political relationship with the Swedes as possible. To understand the British attitude towards Swedish participation in OEEC and later in Uniscan and the connections between British cold war foreign policy and international economic policy in general, a closer look at the nature of the economic interdependence between Britain and Sweden is needed.

\section{Sweden and Scandinavia in British trade and economy}

After the Second World War, the United Kingdom's overseas trade was predominantly concentrated within the British Commonwealth. Britain's three largest trading partners outside this sphere were the US, Sweden and Denmark. Sweden, with a population of

\footnotetext{
${ }^{1}$ For example, Sir Ralph Glyn, Lord Brand and the banking family Hambro were named by the Swedes as representatives of this opinion, Hägglöf to Undén, 29.11.1948, Hp $1 \mathrm{Ba}$, Vol 94, Riksarkivet (RA), Stockholm.
} 
only seven million, was Britain's largest trading partner in Europe in 1947-1953. ${ }^{1}$

Table 1.

UK Atlantic and European trade in million US \$

(imports + exports + re-exports)

1928193819461947194819491950195119521953

$\begin{array}{lrrrrrrrrrr}\text { USA } & 1254 & 719 & 1084 & 1445 & 1024 & 1047 & 950 & 1496 & 1399 & 1196 \\ \text { CAN } & 477 & 518 & 948 & 1149 & 1201 & 1125 & 864 & 1123 & 1266 & 1303 \\ \text { SWE } & 161 & 183 & 221 & 294 & 460 & 407 & 415 & 657 & 550 & 587 \\ \text { FRA } & 514 & 229 & 213 & 244 & 365 & 434 & 462 & 581 & 443 & 443 \\ \text { NETH } & 338 & 216 & 191 & 238 & 374 & 450 & 454 & 581 & 508 & 530 \\ \text { BELG-LX } & 347 & 156 & 185 & 293 & 330 & 309 & 285 & 431 & 455 & 349 \\ \text { DEN } & 308 & 265 & 285 & 218 & 304 & 477 & 467 & 491 & 515 & 585 \\ \text { W.- GER } & 643 & 278 & 121 & 191 & 245 & 263 & 272 & 377 & 430 & 409 \\ (1946-1950 & \text { incl. } & & & & & & & & & \\ \text { E.-GER) } & & & & & & & & & & \end{array}$

$\begin{array}{lrrrrrrrrrr}\text { FIN } & 84 & 123 & 90 & 163 & 222 & 193 & 153 & 373 & 291 & 205 \\ \text { NORW } & 99 & 92 & 105 & 179 & 205 & 244 & 228 & 320 & 297 & 288\end{array}$

UK world trade totals

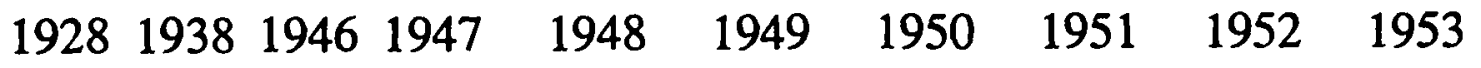

OEEC

$\begin{array}{lllllllllll}\text { (non-f) } & 2818 & 1640 & 1657 & 2130 & 2923 & 3212 & 3175 & 4258 & 3953 & 3914\end{array}$

$\begin{array}{llllllllllll}\text { f AREA } & 2906 & 2488 & 3407 & 4511 & 6233 & 6665 & 5570 & 7592 & 7590 & 7740\end{array}$

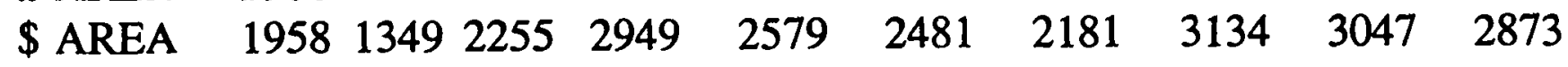

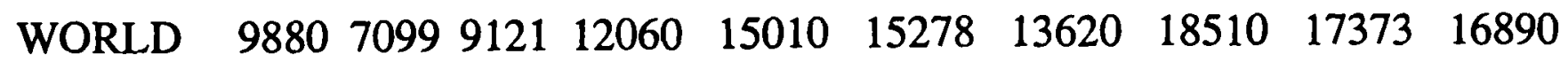

Nevertheless, neither the Scandinavian nor the continental European economies could challenge the primacy of the Dominions, the Commonwealth and the Sterling Area. In

1 The following statistics are derived from Bulletins Statistiques de l'OECE. Commerce Exterieur, Serie I 1928, 1937-1953 (Paris: OEEC, 1954). 
1946-53, the three Scandinavian countries had an average share of 7.4 per cent of Britain's overseas trade, while the area that would later become the 'Little Europe of the six' amounted to no more than 11.1 per cent. This shows that in a European context, Scandinavia had an important place in Britain's trade during these years. Eventually, the importance of the continental economies to Britain increased as they got back on their feet. Nevertheless, at the same time, with the general economic recovery and growth in Europe, Britain's trade with Scandinavia also increased. This followed a longterm pattern, as between 1928-1938, the relative proportion of Anglo-Scandinavian trade had been increasing, whereas the effects of the depression and protectionism had radically decreased the level of British trade elsewhere. As to German competition, in 1937 the Swedes imported only slightly more from Germany than from Britain. ${ }^{1}$ Otherwise Scandinavian trade had traditionally gravitated strongly towards Britain, both in terms of exports and imports.

Scandinavia's increased relative economic importance to Britain in the immediate postwar years was partly due to the extensive but temporary disruption of continental economies. Scandinavian markets had suddenly opened to the British without German competition. The supply of vital raw-materials such as iron ore, timber and other forestry products from Sweden, and foodstuffs from Denmark, highlighted the region's economic significance. British exports to the region were more diversified, but important items were iron and steel, chemicals, machinery, motor vehicles, textiles and coal. ${ }^{2}$ For the Swedes, coal was by far the most important item, and before the war it had amounted to about one third of the value of UK exports to Sweden, and had been about half of

\footnotetext{
${ }^{1}$ Memorandum for Mr. Marquand's (Secretary for the Department of Overseas Trade, Board of Trade) visit to Denmark, Norway, Sweden and Finland, 27.12.1945, FO 371/56223.

${ }^{2}$ Ibid.
} 
Sweden's total coal imports. ${ }^{1}$ This reliance on imported fossile fuels continued after the war.

Table 2 .

Sweden's foreign trade in million US \$

1928193819461947194819491950195119521953

$\begin{array}{lcccccccccc}\text { UK } & 180 & 208 & 185 & 260 & 425 & 374 & 391 & 626 & 509 & 538 \\ \text { W.-GER' } & 195 & 210 & 14 & 36 & 70 & 150 & 262 & 414 & 492 & 457 \\ \text { USA } & 112 & 127 & 249 & 553 & 273 & 166 & 170 & 259 & 255 & 226 \\ \text { BELG+LUX } & 21 & 36 & 86 & 144 & 161 & 127 & 88 & 178 & 173 & 149 \\ \text { NOR } & 35 & 47 & 77 & 112 & 144 & 148 & 134 & 163 & 190 & 175 \\ \text { DEN } & 58 & 52 & 66 & 81 & 87 & 92 & 106 & 125 & 129 & 134 \\ \text { FRA } & 40 & 31 & 69 & 104 & 128 & 108 & 123 & 191 & 158 & 149 \\ -- & & & & & & & & & & \\ & 201 & 235 & 255 & 366 & 603 & 527 & 560 & 914 & 718 & 718 \\ \text { f AREA } & 128 & 135 & 311 & 634 & 349 & 212 & 225 & 356 & 354 & 328 \\ \text { \$ AREA } & 880 & 987 & 1502 & 2350 & 2479 & 2177 & 2280 & 3554 & 3297 & 3053 \\ \text { WORLD total } & & & & & & & & & & \\ & \text { 1946-47 including Soviet occupation zone } & & & & & & \end{array}$

An important characteristic in Britain's economic relationship with Scandinavia was that Anglo-Scandinavian trade was even more important for the Scandinavians than it was for the British. For the Scandinavian countries, Britain was traditionally a market of first rate importance, influencing their economies on a wide front. The fortunes of their economies were linked to those of Britain. After the war in 1948-50, 16.1 per cent of Swedish exports went to Britain and 18.1 per cent of imports were British. ${ }^{2}$

However, even if the long-term growth potential in continental Europe was much

1 Memorandum for M. L. John Edwards, MP (Parliamentary private secretary to the president of the Board of Trade), undated, FO 371/56223.

${ }^{2}$ Alan Milward, The Reconstruction of Western Europe 1945-1951 (London: Routledge, 1987), 318. Denmark was the Scandinavian country most heavily dependent on Britain. In 19485039.6 per cent of Denmark's exports went to Britain, and 29.8 per cent of imports were British. 
larger for both Britain and Sweden, the complementary nature of their economies highlighted the importance of uninterrupted trade, stability in payments questions, and agreements over tariffs and quotas. To achieve all this would require a good deal of understanding on the political level between Britain and Sweden.

\section{Trade policy activated}

During the Second World War, Sweden's association with the Sterling Bloc was terminated. Normal trading relations were nevertheless re-established very soon. Sweden had throughout the war been an open market to UK exporters when supplies and shipping were available, or when economic warfare considerations allowed. Given Sweden's policy of appeasement towards Germany during the war, the British appreciated that the Swedes had kept their trade agreements with them, even when it had appeared that Germany might win the war in $1940 .^{1}$

Although there existed resentment in Britain about Sweden's wartime record of appeasement towards Germany, there were already signs in 1944, that essential material needs overruled political considerations and emotional preferences. Immediately after Sweden closed the Baltic ports to Germany, the British approached them to start negotiations for badly needed timber purchases. ${ }^{2}$ The Americans, with whom the British had agreed to have a joint policy towards neutrals in economic matters, were deliberately presented with a fait accompli. ${ }^{3}$ One of the key raw materials in reconstruction was timber and by 1944, under wartime restrictions, Swedish supply gained a crucial position. In 1945 Labour put great emphasis on housing in their election campaign and

\footnotetext{
' Research Department study, 'Sweden's Foreign Policy', 10.8.1945, FO 371/48042.

${ }^{2}$ FO to Washington Embassy, 29.9.1944, FO 371/43537.

${ }^{3}$ A. F. Haigh minute, 27.9.1944, FO 371/43537.
} 
both Swedish and Finnish supplies were considered 'absolutely essential for our housing schemes' and thus influenced Labour's domestic political fortunes long into the postwar period. ${ }^{1}$ Knowing this, the Swedes used timber as an effective bargaining weapon, but only after tough negotiations where concessions had to be made on both sides. ${ }^{2}$ Later, when reconstruction gave way to rearmament in 1950, the Swedes used iron ore in the same way as they had done with timber earlier. ${ }^{3}$

Sweden's assistance was also needed because of Britain's financial difficulties. The Treasury stated in May 1944, that Sweden's cooperation was needed in helping to overcome the strain on Britain's balance of payments by holding considerable quantities of sterling, i.e., giving short-term credit to Britain for purchases in Sweden. ${ }^{4}$ After long negotiations, in March 1945 the Swedes accepted British terms for a payments agreement, which was in London considered an important step towards a British led economic group in Europe based on sterling as a reserve currency, and in Stockholm as a necessary step towards the economic stabilisation of Europe. ${ }^{5}$ Despite this, there were many in Sweden who were not altogether pleased with the favourable treatment of the British and with the strong linkage of the Swedish economy with sterling. ${ }^{6}$ For Britain's already limited leverage over the Swedes in questions of foreign policy, the payments agreement did no good, gave as it did the Swedes a lever over the British, who would have to count on continuing Swedish goodwill in economic questions.

The optimism about developing Britain's relations with Sweden through the medium of trade was expressed in various occasions during the summer 1945. On leaving

\footnotetext{
' Kenneth O. Morgan, Labour in Power, 1945-1951 (Oxford: Clarendon Press, 1984), 163 165; Memorandum for M. L. John Edwards, undated; Memorandum for Mr. Marquand, 27.12.1945, FO 371/56223.

${ }^{2}$ Board of Trade note, 21.4.1945; FO to Stockholm, 14.8.1945; BT 11/2543.

${ }^{3}$ T. Stanes to S. H. Levine, 10.10.1950, BT 11/2893; Nilson, 'No Coal Without Iron Ore'.

${ }^{4}$ Ludlow, 'Britain and Northern Europe', 157.

${ }^{5}$ Ibid., 158.

${ }^{6}$ Ibid., 158 - 159.
} 
Sweden, Mallet ended his final assessment of Sweden's wartime record and present international position in an optimistic note:

Swedish policy ... while endeavouring to keep on friendly terms with the Soviet Union, will tend towards the closest possible relationship with Norway and Denmark and will resent any attempt by Russia to counteract such a tendency. Sweden's need for foreign trade will drive her more towards western markets now that Germany is no longer available for large-scale trading. She will seek close ties with the United States of America, but her people's genuine admiration and affection for Great Britain, immensely increased by the British achievement during the war, afford us a real opportunity not only for the closest political and cultural relations but for a valuable market for our exports. ${ }^{1}$

This optimism about the future of Anglo-Swedish relations, although more reserved as to the political side, was also expressed in a FO Research Department study of Sweden's foreign policy, which concluded, that 'Sweden's foreign policy in the immediate future is likely to aim mainly at improved relations with Russia, closer relations with her sister Scandinavian nations, and more intimate cultural and economic relations with the AngloSaxon Powers, especially with Great Britain'. 2 In his 'maiden speech' as foreign secretary in the House of Commons on 20 August, Bevin, not surpisingly, concentrated on the economic aspects of Britain's relations with the Scandinavians. ${ }^{3}$

Following the transition from war to peace, British trade policy was quickly activated in Scandinavia. Due to the importance of securing the supply of Scandinavian rawmaterials and the need to open markets for British exports, the Secretary for Overseas Trade Hilary Marquand visited Denmark, Norway, Sweden and Finland in early 1946. Unfortunately, he could bring no definite promise about when British exports of coal, steel and textiles, very much in demand in Scandinavia as well as elsewhere, could be

\footnotetext{
${ }^{1}$ Mallet to Eden, 17.6.1945, FO 371/48042.

2 'Sweden's Foreign Policy', 10.8.1945, FO 371/48042.

${ }^{3}$ FO telegram to Oslo, Stockholm, Copenhagen and Helsinki, 21.8.1945, FO 371/47450.
} 
returned to their pre-war level. ${ }^{1}$ Economic stringency at home, and especially the balance of payments difficulties, also limited Britain's ability to import more than essential raw materials from Scandinavia.

This situation, whereby Britain was importing considerably more from Scandinavia than it was exporting, was accepted as a fact of life by the Scandinavians in the hope that the transitory period would not last too long. In the meanwhile, the Scandinavians, especially the Swedes and the Danes, agreed to hold sterling to cover the difference between imports and exports. The Swedes preferred to hold additional sterling rather than reduce their exports to Britain. ${ }^{2}$ This put them on the long queue of Britain's overseas creditors.

Despite the fact that Anglo-Scandinavian trade in the immediate post-war period was thus reduced to essential requirements, the long range possibilites of Anglo-Scandinavian trade were greater. To secure this, long-term British commercial strategy was to limit as far as possible the effects of Germany's future economic recovery in Scandinavia. The Board of Trade anticipated in 1945 that whereas for the next couple of years Britain would have an increased share of Scandinavian markets, they would eventually face intensified competition from Germany. This made it all the more important 'that we should seize the opportunity we have of strengthening our position in these markets over the next two or three years'. ${ }^{3}$ The problem was with what goods they could conquer these markets.

As a market for British goods, postwar Scandinavia seemed promising for British exporters. 'Under conditions of full employment and rising prosperity here after the war, all four countries, as suppliers of basic raw materials and foodstuffs, can expect an expanding demand for these products here', Board of Trade officials wrote in December

\footnotetext{
${ }^{1}$ Memorandum for Mr. Marquand, 27.12.1945, FO 371/56223.

${ }^{2}$ Memorandum for M. L. John Edwards, undated, FO 371/56223.

${ }^{3}$ Memorandum for Mr. Marquand, 27.12.1945, FO 371/56223.
} 
1945. This in turn provided the Scandinavians with 'ample sterling for the purchase of all we are likely to be able to supply for some time to come'. The British ability to export was and remained the main problem in Anglo-Scandinavian trade and economic co-operation. Even with the elimination of Germany as a supplier of many engineering, metal and chemical products, the main bottlenecks to expanding Anglo-Scandinavian trade were not to be found in the markets, but in British production. The most serious difficulty was the inadequate supply of British coal. This limited the political usefulness of trade and economic cooperation in Anglo-Swedish relations.

The opening of Baltic trade worked also in another direction. In 1946 the Swedish government concluded a trade agreement with the Soviet Union. It contained an agreement of a loan of one billion Swedish crowns (c. $£ 70$ million in 1946 figures, c. $£ 700$ million in 1998) to the Soviet Union for purchases from Sweden. The American government's response to the loan agreement was very critical. ${ }^{1}$ In 1946 when the negotiations were underway, the US minister in Stockholm left a note to Erlander about the alarming prospects the bilateral agreement might have on Sweden's economic orientation. On the face of it, the Americans criticised the agreement as being against the principles of multilateral trade and its liberalisation. But the main motivation behind US criticism was in the prospects that economic cooperation over the Baltic sea opened from the political point of view. The Americans did not want new economic links opened between those powers that were considered 'Western', as defined by the steadily deepening cold war, and the Soviet Union.

The British attitude, by contrast, towards Sweden's trade with the Soviet Union and the Eastern European countries as a whole, was very different from the US. This was all the more striking, as Britain was Sweden's largest trading partner and had far more to lose from its possible economic reorientation. The British did not criticise the Swedish-

\footnotetext{
${ }^{1}$ Karlsson, Handelspolitik eller politisk handling, $39-51$.
} 
Soviet trade agreement. This was despite fears from the Stockholm embassy that the Russians' economic leverage now had 'a stick with which to beat the Swedes' and possibly 'influence Swedish foreign policy at some critical moment'. ${ }^{1}$ On the contrary, an increase in Sweden's Eastern trade was welcomed. It had been Bevin's policy in August 1945 not to cut off Eastern Europe economically, even if politically the situation there went against British interests. ${ }^{2}$ Generally speaking, the British thought that expansion of trade with hitherto isolated parts of the world was a good thing in itself. With Eastern Europe, trade also had a political bearing, but not in the same way as the Americans saw it at that stage. According to British thinking, East-West trade might eventually loosen the hold of the Soviet Union over its satellites. As was done with Finland, maintaining that country's economic contacts with the West was an aspect of British policy that was, as we now know, immensely important.

An increase of economic activity between Sweden and the Soviet Union was considered an additional and welcome opportunity to link the economies in the Soviet orbit with the West. ${ }^{3}$ Sweden could be used as a meeting point between the Eastern and Western economic spheres. The whole problem was formulated in the FO as follows: 'Multiplying commercial relations between countries of the type of Sweden and Switzerland and those within the Soviet orbit ... has the general merit of "keeping a window open to the West" and would appear to be the goal at which our commercial policy is aimed with regard to the "trans-curtain" countries'. ${ }^{4}$ With an increase of Swedish trade with the Soviet Union came prospects of a similar increase in trade with

\footnotetext{
${ }^{1}$ Jerram to Bevin, 11.2.1947; Stockholm chancery to Northern Department, 8.5.1947, FO $371 / 66508$.

${ }^{2}$ Record of an interdepartmental meeting in the FO, Sargent, 14.8.1945, Pelly, M. E. \& Yasamee, H. J. \& Hamilton, K. A. (eds.), DBPO Ser. I, Vol. VI (London: HMSO, 1990), microfiches.

${ }^{3}$ L. T. Gandy minute, 3.3.1947, FO 371/66508.

${ }^{4}$ T. T. Hughes (Economic Intelligence Department) minute, 17.3.1947, FO 371/66508.
} 
Poland and Czechoslovakia, among others. This, indeed, also seemed to take place in 1947 with the Balkan countries. The neutrals, such as Sweden or Switzerland, could provide a window - if not a gate - in the iron curtain, at least economically.

Annual acrimony: The bilateral trade framework

Despite American pressure for the liberalisation of international trade in the postwar world, the general framework of Anglo-Scandinavian trade after the war was based on annual, bilateral trade agreements that covered both the overall levels of trade, and its breakdown to various items and payments questions. Anglo-Scandinavian trade agreements were not exactly similar to the 'barter' agreements that existed between most European countries who exchanged specific quantities of specific goods as a means of getting mutual trade going again. In the Anglo-Scandinavian trade agreements the quantities of specific goods were agreed in the so-called 'informatory lists', which were not quarantees of supplies of the goods listed, but rather a general indication of goods available for trade between the respective countries. ${ }^{1}$ If, for example, British exports of coal fell considerably below the figure in the informatory lists, the Swedes could cut their exports of timber and iron ore respectively, in order to maintain a rough balance in the trade and create an incentive for the British to maintain the agreed level of coal exports.

Within this framework, payments arrangements between Britain and the Scandinavian countries were based on a network of monetary agreements by which each of the Scandinavian countries undertook to hold sterling to the extent of the difference between imports and exports. The UK took a similar undertaking in respect to the Scandinavian currencies. It served as a crude basis for expanding trade and gave some flexibility in an

\footnotetext{
${ }^{1}$ Memorandum for Mr. Marquand, 27.12.1945, FO 371/56223.
} 
otherwise inflexible international trade situation, where most European currencies were subject to exchange controls. The annually negotiated informatory lists were also for the Swedes a way to control the probable volume of credit they gave Britain in the form of their sterling balances. ${ }^{1}$

The annual trade negotiations were never easy. In addition to shortages of British coal for export, the main problems were due to the long term imbalance and in the ensuing sterling balances the Swedes had to hold. One year after the trade agreement of March 1945, the Swedes held $£ 25$ million and the chances were that this would be much more in the future. What this meant in practice was that Swedish exporters might try to direct their exports into hard currency countries instead of Britain, whose economic condition was such that warranted the sort of help the Swedes could not give. Despite a mutual interest to have Britain back on its feet economically, the situation tested the Swedes' nerves. Knowing this, the President of the Board of Trade Sir Stafford Cripps told Gunnar Myrdal, the prominent economist and Sweden's trade minister in 1946:

We are proud, Professor Myrdal, of these honourable wounds to our economy, and we are certain that our Swedish friends will regard them with sympathy and understanding. Patience in recovery is required from our own people and from all those who believe that our sacrifices were made in a great cause, the cause of world freedom. ${ }^{2}$

The message implicit here was that neutral Sweden should not be too strict in its dealings with Britain. It, after all, had fought for the freedom of Sweden as well, and arrears resulting from this would have to be paid long into the future.

But economic realities had a life independent from political sympathies, or feelings of guilt, and that life was becoming harder for everyone in 1947. In June 1947, the

\footnotetext{
${ }^{1}$ Ellis-Rees minute, 21.3.1947, FO 371/66501.

${ }^{2}$ Cripps speech at a lunch with Myrdal, undated (spring 1946), File 420, Sir Stafford Cripps Papers, Nuffield College, Oxford.
} 
situation in the Anglo-Swedish negotiations had reached a point where Assistant UnderSecretary Sir Roger Makins warned his colleagues in the FO that the tense atmosphere surrounding Anglo-Swedish trade and payments arrangements might have undesirable political consequences. ${ }^{1}$ Hugh Ellis-Rees, who in 1947 was in charge of the negotiations with Dag Hammarskjöld, the leader of the Swedish team, maintained optimistically that even if the negotiations were at times in a breaking point, personal relations were still very good and that the meetings even had some positive value in bringing together the officials from both countries. ${ }^{2}$ Hankey also believed that hard bargaining would not hurt Anglo-Swedish relations, provided that the end result was satisfactory. If something was wrong, it was because of the 'confusion' created in Sweden by the 'dangerous genius Myrdal', as Hankey described him in June $1947 .{ }^{3}$ The confusion Hankey referred to had arisen from a combination of revaluation of the Swedish crown, which made Swedish products less attractive abroad, with a substantial increase in imports that led to a rapid diminution of Sweden's hard currency reserves.

Then, after the ink was barely dry on a supplementary trade and payments agreement of July 1947 that managed to solve the most acute problems in Anglo-Swedish trade, came the sterling convertibility crisis of August 1947. 'Myrdal's confusion' in Sweden was insignificant compared with the turmoil that the convertibility of sterling and its rapid suspension caused. Confidence in sterling, which the Swedes held in considerable amounts, dropped to an all-time low. The Swedes were already in trouble with their dwindling dollar reserves, and on the top of that they now had the effects of the British crisis.

The suspension of sterling convertibility on 20th August 1947 meant that previous Anglo-Swedish trade and payments agreements needed to be re-negotiated and Sweden

\footnotetext{
${ }^{1}$ Makins minute, 13.6.1947, FO 371/66518.

${ }^{2}$ Ellis-Rees report on Anglo-Swedish negotiations, May 1947, FO 371/66518.

${ }^{3}$ Hankey minute, 20.6.1947, FO 371/66518.
} 
would also in the future have the problem of what to do with the mounting sterling balances. This was hardly an incentive to expand Sweden's trade with Britain, or to consider closer economic cooperation. The new agreement was reached in due course in the autumn of 1947 and trade was quickly resumed. But the whole episode of first, after hard negotiation, reaching an agreement, then nullifying it with the suspension of convertibility and re-negotiate, did nothing to further British economic interests in Sweden. Psychologically, as confidence in sterling - or the lack of it - remained of paramount concern for Britain, this experience displayed the limited potential of economic diplomacy in Anglo-Swedish relations.

The framework of annual trade negotiations was necessary as long as liberalisation of international trade and payments was still in the future, but no-one liked it and there was a strong awareness on all sides that in unfavourable economic circumstances this system of economic relations management contained a political timebomb. Every year the clock was turned 12 months back barely in time before an explosion. In 1947-48 it went off with the Belgians who preferred to cut down trade with Britain or insist on gold payments to meet the unfavourable balance, leading to considerable resentment on both sides and the subsequent orientation of Belgium in economic questions towards its continental neighbours. ${ }^{1}$ In late 1947 trade negotiations with Denmark had reached a complete deadlock, the main dispute being the price of imported Danish foodstuffs. ${ }^{2}$ In 1948-49 problems abounded with Norway over fishing and with Swedes over coal.

That the problems inherent within this system of bilateral trade negotiations had direct political significance was witnessed by Sir Orme Sargent's intervention in early January

\footnotetext{
1 Thierry Grosbois, The European policy of Belgium and Luxembourg, from the war to the cold war and the attitude of Britain, 1943-48, (unpublished paper in the conference 'Britain anc the Cold War', Institute of Historical Research, London, 15 - 18 July 1997).

2 Leon Dalgas Jensen, 'Denmark and the Marshall Plan, 1947-48: the Decision tc Participate', SJH, Vol. 14, No. 1 (1989), 75; Bengt Nilson, 'Butter, Bacon and Coal', 257 - 77
} 
1948, when he told Attlee that 'we are anxious to do all that we can to strengthen the present Danish Government ... It is also unfortunate that our commercial links with Denmark should be weakened at a time when we are trying to draw Denmark closer to us'. ${ }^{1}$ The beneficial linkage between trade and foreign policy was far from clear cut. The problem was addressed in the Cabinet in March 1948, when it was suggested that 'the possibility of affording greater economic assistance to Scandinavian countries, possibly by long-term agreements, ought to be considered'. ${ }^{2}$ With Finland, the situation was less problematic, and a satisfactory trade agreement had been made, securing Britain with supplies of wood, pulp and timber. ${ }^{3}$ Finland's Western trade also prevented the Soviet Union from acquiring a stranglehold over the Finnish economy. To maintain this lifeline was a central feature in Britain's policy towards Finland. ${ }^{4}$ Nevertheless, even with Finland, Britain could not afford much actual help besides normal commercial contracts, as Cripps made clear to the Finnish minister in London, Eero A. Wuori. ${ }^{5}$

In the case of the other Scandinavian countries, the linkage of trade and foreign policy was even more problematic. Although the economic relationship was beneficial for both sides, the acrimony of annual trade negotiations was due to hard bargaining and followed the rules of competetive international trade. The levels of trade were high enough to mean that even small concessions from the British side to further political goals, were costly and could significantly influence its basic economic interests. From the purely political point of view, not to speak of economics, dollars were sorely needed to ease the potential for trouble in Britain's economic relations with these countries.

While in the Cabinet's and FO's view, economic assistance and preferential terms of

\footnotetext{
' Sargent to Attlee 6.1.1948, FO 800/500.

${ }^{2}$ Cabinet minutes, 5.3.1948, CAB 128/12.

${ }^{3}$ Cabinet minutes, 4.3.1948, CAB 128/12.

${ }^{4}$ FO memorandum, 'Scandinavia: the present political outlook', 30.3.1948, FO 371/71447.

${ }^{5}$ Wuori to Enckell, 17.2.1947.
} 
trade were useful tools of foreign policy, the issue depended on purely economic and financial considerations. Given Britain's difficult economic and financial position and the relatively large volume of Anglo-Scandinavian trade, the problem was not one that could be solved simply. As E. T. Casdagli from the Board of Trade wrote to the FO in April 1948: 'If greater economic assistance is to be given to Scandinavia the prime mover will need to be the Treasury who will have to agree that either larger credits can be given or existing debts to us can be increased'. ${ }^{1}$ This conflicted with the fundamental aims to achieve equilibrium in the balance of payments position, and an increased economic assistance to Scandinavia would have required the Treasury to modify this policy.

The problem was that the British were already buying as much from Scandinavia as they could, and import restrictions based on the balance of payments position limited any radical liberalisation of trade. The Board of Trade was very sceptical about whether an increase in Scandinavian imports could have been justified, as the Scandinavians in their view already enjoyed a relatively preferential position. Hankey's discussions with Treasury officials confirmed this, as in their view there was not much more Britain could do for the Scandinavian powers 'without sacrificing our economic interests', which in the end might not bring Britain any comparable political advantage that would be worth the price. $^{2}$ A decision of this kind would have to be taken on ministerial level. In the end, economic interests outweighed political concerns, and the Cabinet's decision in March 1948 to study the possibilities of granting the Scandinavians more economic favours did not lead to any immediate actions on the political level.

By the time the European Recovery Program started to take shape, the overall temperature within the system of Anglo-Scandinavian trade and economic relations management rose to a level that it needed defusing before it went off on its own.

\footnotetext{
${ }^{1}$ Casdagli to Hankey, 12.4.1948, FO 371/71451.

${ }^{2}$ Hankey minute to private secretary, 13.4 .1948 , FO $371 / 71451$.
} 
Otherwise the political significance of Britain's trade relations with Sweden and the other northern countries would be exactly the opposite from that intended.

\section{From Harvard to Paris}

Marshall's speech in Harvard on 5th June 1947 about American economic aid to Europe, marked a new age in the American involvement in European affairs. ${ }^{1}$ His opening was quickly seized by Bevin and Georges Bidault in June and a conference of European nations in Paris was convened to develop a plan for the reception of American aid. ${ }^{2}$ To modify Geir Lundestad's thesis about the 'American empire by invitation', ${ }^{3}$ Marshall's speech and the subsequent European Recovery Program shows that the American empire could more accurately be described as an empire that invited the Europeans to invite it.

Marshall's irresistible offer provided Bevin with very useful means to pull the more hesistant Scandinavians into closer Western cooperation. If political and military alignment was not yet an option for them, then cooperation on the economic sphere seemed a more promising start. But in order to achieve Scandinavian and especially Swedish participation in the projected programme, the Scandinavians needed to be reassured that this was not a step for blockbuilding and a division of Europe into East and West.

Besides political motives to bring Scandinavia into closer economic cooperation with other Western powers, in the case of Sweden also purely economic calculations spoke

1 Melvyn P. Leffler, A Preponderance of Power. National Security, the Truman Administration, and the Cold War (Stanford: Stanford University Press, 1992), 157 - 164.

${ }^{2}$ On the Paris negotiations, Deighton, Impossible Peace, 171 - 206.

${ }^{3}$ Geir Lundestad, The American "Empire", and Other Studies of US Foreign Policy in a Comparative Perspective (Oxford \& Oslo: Oxford University Press and Norwegian University Press, 1990), 54 - 62. 
for its participation. Any work done in the framework of the Marshall plan would inevitably affect Britain's economic relations with Sweden as well, and given the predominant position of Sweden in Britain's economic relations with Europe, it made sense to have that country around the same table even from the practical and technical point of view. American dollars could also help in easing problems in the system of annual trade negotiations by providing more leeway for the negotiators. Sweden's sterling balances would also be less of a problem if the overall balance of payments situation was better; in Sweden as almost everywhere in Europe, a shortage of dollars was a serious problem in 1947. Eventually, with more liberal international trade, these problems, it was hoped, would vanish altogether.

In the first discussions with the Scandinavian diplomatic representatives in London about Marshall's speech and Bevin's talks with Bidault, Makins stressed that the British 'were looking at the matter from an economic and not a political point of view'. ${ }^{1}$ The same reassuring and conciliatory tone was adopted on the question about what the role should be for the recently established United Nations Economic Commission for Europe, now headed by Gunnar Myrdal. ${ }^{2}$ The British strategy to get the Scandinavians to take part in the proposed plan was complicated by the ECE issue. Voices were raised in London in early June, that too rigid a line leading into the economic division of Europe into two antagonistic blocs might lead the Scandinavians, and possibly even others such as France, to refuse cooperation with Britain and the US on such terms. ${ }^{3}$ The British, however, had no intention of handing over responsibility to this body, which would be

\footnotetext{
${ }^{1}$ Makins minute, 17.6.1947, FO 371/65899.

${ }^{2}$ Ibid. On the ECE, Sevón, Visionen om Europa, 110 - 176.

${ }^{3}$ Record of conversation between Troutbeck, Makins, Hankey and Radice, 5.6.1947, FO 371/62399. The 'voice' was of Sir D. Waley's.
} 
like 'asking it to run before it can walk' ${ }^{1}$ Nonetheless, for a variety of political reasons, the blunt by-passing of a UN body was not advisable. As the Scandinavians were the main protagonists for ECE to take over the preparations for the Marshall Plan, they needed lobbying and persuasion to favour the British-French plan. ${ }^{2}$

The Soviet Union's refusal to continue to participate in the exploratory talks in Paris on 2 nd July put the Nordic countries in a difficult position. All these countries had, this far, been able to avoid chosing sides in the increasingly tense international situation. Alarmed by the gloominess of the Norwegian diplomats in London after Molotov's threatening remarks, Bevin doubted whether even Norway would be able to accept the invitation to the Paris conference. ${ }^{3}$

Sir Roger Stevens and Hankey discussed the position of the Scandinavian countries on 4th July and reasserted the view that 'it is obviously most desirable that they should come in and Sweden in this connection is in a key position'. It would be decided now, they maintained, whether the Scandinavians would continue to sit on the fence or join the West in this issue. The most important thing was first to have the Swedes make the right decision. This in mind, the British approached the new Swedish minister in London, Erik Boheman, who was well known both for his pro-Western views and for his influence in Stockholm, to 'supply him with all the arguments possible' to combat Molotov's argument that the work in Paris was leading into a division of Europe. ${ }^{5}$

The FO made seven points for Swedish consumption. First, the Anglo-French

\footnotetext{
${ }^{1}$ Ibid. On Western attitudes towards the ECE, Michael Hogan, The Marshall Plan. America, Britain, and the Reconstruction of Western Europe, 1947-1952 (Cambridge: Cambridge University Press, 1987), 52 - 53.

${ }^{2}$ FO brief, 17.6.1947, FO 371/62399.

${ }^{3}$ Makins minute, 4.7.1947; Dixon minute 5.7.1947, FO 371/62409; Lundestad, America, Scandinavia, and the Cold War, 82. On Norway see further, Helge Pharo, 'Bridgebuilding and Reconstruction, Norway faces the Marshall Plan', SJH, Vol. 1, No. 1 (1976), 125 - 153.

${ }^{4}$ Stevens minute, 4.7.1947, FO 371/62409.

${ }^{5}$ Ibid.
} 
proposal involved 'no shadow of derogation from national sovereignty'. Second, the aim was not to cut down intra-European trade. Third, neutrals and allies were in the scheme on the basis on equality, whereas the Russians were insisting that allies should have priority. Fourth, there was 'no reason why Europe should be divided into East and West on this issue or indeed why the issue should be treated as a political one' and whatever the Russians were saying, the Anglo-French proposal was a 'business like attempt to get as many countries as possible in Europe to take advantage' of Marshall's offer. Fifth, the British were not putting forward any definite proposals as to how the Swedes should take part and realised that 'the Swedes may feel that because their economic position has been better than that of many European countries, they will be expected to participate as contributors rather than recipients'. The British, on the contrary, said that anything that the Swedes were able to do would be entirely voluntary and that the British were well aware that Sweden was short of dollars and this would be taken into consideration. ${ }^{1}$ Sixth, those who did not participate were unlikely to receive any aid. And, finally, as the most forceful argument the British hoped:

[T]hat the Swedes will realise that they are themselves essentially a part of the Western world and that they will not associate themselves with what appears to be a Russian attempt to prevent the Western world from preventing its own disintegration. If the Swedes were to stand out at this juncture this would in effect mean that they associated themselves with the Russian point of view on this topic. $^{2}$

This, if anything, was language typical to the cold war. Whatever Boheman's and the general Swedish perception of the implications of the Marshall plan for the division of

\footnotetext{
${ }^{1}$ Ibid. Cay Sevón has said in her dissertation that the British thought the Swedes should come in on the donating side, but this view finds no support in FO material. On the contrary, the crux of the matter was that Sweden had to be told that its contribution was not to be expected. Ibid; Sevón, Visionen om Europa, 181 - 183.

${ }^{2}$ Stevens minute, 4.7.1947, FO 371/62409.
} 
Europe had been, the last point seemed to confirm what the other points were trying to dispute: the question ultimately was about choosing sides in the deepening rift between East and West. That rift was rapidly extending beyond the remit of traditional diplomacy, into economic and trade questions and into the complicated realm of fundamental ideological choices between different socio-economic and socio-political orders. From a purely economic viewpoint, it was imperative that Sweden should be able to retain its links with the West. By 1947, economic choices, however, were no longer distinguishable from political ones and the Marshall plan became the potent symbol of this. The British role in trying to persuade the Swedes to join it from the outset was particularly characteristic of the ways this politicization took place. While the Americans remained in the background, the British worked with the Swedes, now with adequate material means to do so. Yet, Scandinavian participation was far from being a one-sided affair, dictated by the British or the Americans, but was a result of a negotiation process. In this negotiation process fundamental British and Swedish interests converged. Britain, for its own reasons, wanted to keep the Marshall plan from growing political functions superseding that of London. Sweden, for its part, wanted the same in order to maintain the distinction between its politico-military nonalignment and its ideologico-economic belonging to the West.

The seven points prepared in the FO were put forward by Bevin, and reinforced by Morrison and Cripps, in discussions with Boheman on 5th July, before the latter returned to Stockholm for consultation with his government. Bevin stressed his 'warm wishes' that Sweden would accept the invitation to the conference in Paris and deplored the Russians' attitude. He said that he did not believe that the conference would lead to a division in Europe, rather the contrary. The Soviets were in his view bluffing and there was nothing to be gained if some countries were amenable to this kind of pressure. Boheman's personal view was that Sweden was likely to join. Supplied with the British views, he 
travelled to Stockholm where he successfully put his weight behind Swedish participation in the Paris conference. ${ }^{1}$

The first good news came on 9 July from the secretary general of the Swedish Foreign Ministry, who unofficially assured the British that the forthcoming reply to Bevin's invitation would be positive. ${ }^{2}$ On balance, it was soon clear that Finland was not able to join. ${ }^{3}$ Whether anyone was deliberately looking for a definite break of Europe into two blocs or not, the fault line in this issue went along the Swedish-Finnish border. From the British point of view, this was regrettable, but Scandinavian participation was considered with great satisfaction in London. The Scandinavians sent strong teams to work on the plan, including Dag Hammarskjöld in the Swedish delegation. In the AngloFrench dominated Executive Committee of the Committee of European Economic Cooperation (CEEC), one seat was taken by Norway to represent Scandinavian interests. ${ }^{4}$

The participation of the Scandinavian countries in the work of the CEEC led to almost immediate protests in the Soviet media. Sweden in particular was subjected to considerable criticism in an article published in Izvestiya on 13 July, where the Western orientation of Sweden was coupled with 'intensification of American influence in Sweden's economy'.5 It was said that the Americans were using the dollar shortage to achieve a stranglehold over the Swedish economy, using pressure against the Swedish oil industry's nationalisation plans and forcing the Swedes into a disadvantageous trade agreement with the US. This economic penetration was supported with an 'ideological

\footnotetext{
${ }^{1}$ Boheman's telegram to Stockholm, 5.7.1947, H 7 L, Vol. 371, RA. On the Swedish decision, Sevón, Visionen om Europa, 177 - 189; af Malmborg, Den ståndaktiga nationalstaten, $71-75$.

${ }^{2}$ Stockholm telegram No. 515 (Henderson) to FO, 9.7.1947, FO 371/62409.

${ }^{3}$ On Finland, see Mikko Majander, 'The Limits of Sovereignty. Finland and the Question of the Marshall Plan in 1947', SJH, Vol. 19, No. 4 (1994), 309 - 326.

${ }^{4}$ Milward, The Reconstruction of Western Europe, 65.

5 'Campaign of the American Dollar against Sweden', a translation of Izvestiya, 13.7.1947, FO $371 / 66497$.
} 
invasion' of the US into the life of Sweden. The American way of life was projected through media, seeking 'to inject the Swedes with the "vaccine of submission" to the United States and ideologically to justify US expansion in the north.' ${ }^{1}$

The comment in the FO on this interpretation of the situation was that a great deal in the article was true. ${ }^{2}$ In British eyes, the American officials themselves made matters worse in Sweden 'by occasional indiscretions and tactlessness' and thus helped to strengthen the image of a US planning for the economic domination of Europe. ${ }^{3}$ 'The Swedes find the Americans a trifle patronising', it was minuted in the FO, perhaps telling as much of British as of Swedish perception of US policy in Europe. ${ }^{4}$

If the Soviet response was critical, the decision of the Swedes to accept the invitation was seen in London as an important departure from the previously more cautious Swedish line. 'Although the watchword is still neutrality, the unqualified acceptance by Sweden of the invitation to Paris to discuss the Marshall plan has clearly indicated where her sympathies lie', Jerram wrote from Stockholm. ${ }^{5}$ In a similar vein, 'the Russians seem to be pushing the Swedes away towards us', Hankey observed in late August $1947 .{ }^{6}$ Sweden, with the other Scandinavians, seemed to be shifting its stance towards the West, even if Soviet propaganda was not without effect in keeping Western cooperation a sensitive issue. ${ }^{7}$

The establishment of the OEEC in April 1948, and the simultaneous process leading to the Brussels Treaty, signified a major step ahead in institutionalising Western

${ }^{1}$ Ibid.

${ }^{2}$ Warr minute, 21.7.1947, FO 371/66497.

${ }^{3}$ Jerram to Bevin, 21.7.1947, FO 371/66506.

${ }^{4} \mathrm{~A}$ handwritten minute on the margin of the above, uninitialled, undated. FO 371/66506.

5 Jerram to Bevin, 21.7.1947, FO 371/66506.

${ }^{6}$ Hankey minute, 30.8.1947, FO 371/66506.

${ }^{7}$ Jerram to Bevin, 21.7.1947; Barclay minute, 18.8.1947; 'Sweden Shifts Toward the West. American Moves Toward World Leadership Begin to Wean Scandinavian Nations Away from Soviet Orbit', New York Herald Tribune, 3.8.1947. 
economic and political cooperation. ${ }^{1}$ From the perspective of Britain's relations with the Scandinavians, the latter's participation in OEEC was particularly important, as the Brussels pact, that was set up in March 1948, was confined to Britain, France and the Benelux. As will be discussed in the next chapter, by then Bevin's approach to Scandinavia, and Sweden in particular, had crystallised along the lines that a separate approach with his 'Western Union' scheme, launched in January 1948, was needed. Especially with neutral Sweden, the best way to pull it closer to West was thought to be by developing existing economic ties. In January 1948 this aspect of Sweden's connection to Britain was considered, perhaps too optimistically, to give the British grounds to believe that Undén's line was slowly veering Westwards and that participation in the OEEC would justify the UK to expect more wholehearted support in the future. ${ }^{2}$

But despite this, the structures of Anglo-Scandinavian and Anglo-Swedish economic interdependence did not automatically bring about any revolution in the relations of the countries on the political level. Trade as a foreign policy tool was a very difficult one indeed, and one that Britain could hardly use without substantial American assistance. On the other hand, the embryonic pattern of coordination and cooperation between Britain and the Scandinavian countries in the OEEC was a promising aspect of AngloScandinavian relations, and a beginning of a relationship that became more important in the future. But what the establishment of the OEEC proved was that a great deal of the political potential that was contained in Anglo-Scandinavian economic cooperation was based not on pounds sterling, but on the steady flow of dollars in the European economy.

Britain's work with the Scandinavians, and Dag Hammarskjöld of the Swedish delegation in particular, started well. It was an additional proof of the wisdom of having

'Daniel Barbezat, 'The Marshall Plan and the Origin of the OEEC', Richard T. Griffiths (ed.), Explorations in OEEC History (Paris: OEEC, 1997), 33 - 47.

2 Jerram telegram No. 30 to FO, 18.1.1948; Talbot minute, 20.1.1948; Jerram telegram No. 41 to FO, 22.1.1948. See also af Malmborg, Den ständaktiga nationalstaten, 98. 
the Swedes in, and on many questions their interests converged. The first arose from the Americans' dislike of international trade and economic policies, which were based on controls, cartels or bilateralism. ${ }^{1}$ Social democracy as such was not particularly resented in Washington, after all it represented a useful frontline in the fight against communism. ${ }^{2}$ Nevertheless, the Scandinavians and the British shared the view that the removal of currency and trade controls should not be enforced as it would endanger their domestic economic and social policy objectives. ${ }^{3}$ If the British could maintain their system of regulations, it also gave the small Scandinavian countries some protection in their dealings with Washington. ${ }^{4}$

Another point of convergence became also soon apparent. A division into the US and continental Europe against Britain and Scandinavia was seen in the discussions of the form the organisation of the Marshall Plan should take. The British were against a supranational planning authority, and were supported by the Swedes and the Norwegians. The Danes were more willing to accomodate themselves with American demands. ${ }^{5}$ The Swedes and the Norwegians also opposed the establishment of a permanent organisation, and found support from the Swiss and initially also from the British.

In September 1947 the British had to give way to American pressure and accepted that a permanent authority was needed in one form or another. After that, the Swedes and the Norwegians had also to give up their attempts to have Marshall Aid administered through the United Nations. The British had not been keen to give Myrdal's organisation any central role in running the ERP to begin with, and were not unhappy to see the Economic Commission for Europe confined to being an expert body. This episode nevertheless

${ }^{1}$ Lundestad, America, Scandinavia and the Cold War, $112-123$.

${ }^{2}$ Ibid., 123 - 131.

${ }^{3}$ Milward, The Reconstruction of Western Europe, 53.

${ }^{4}$ Lundestad, America, Scandinavia, and the Cold War, 149.

5 Dalgas Jensen, 'Denmark and the Marshall Plan, 19497-48: the Decision to Participate', $64-65$. 
showed how Sweden and Norway, together with Britain and Switzerland were strongly against any giving up of national sovereignity to supranational authorities. ${ }^{1}$ It also showed, that the Scandinavian countries had to follow the British lead.

Even after Britain had to consent to the establishment of the continuing organisation, an important British objective was to limit its existence to the period of the programme. Also on this issue, concessions eventually had to be made. Nevertheless, the front needed to be maintained against admitting this, as was explained to the Cabinet on 6 March by Bevin and the new Chancellor of the Exchequer Sir Stafford Cripps. They said that the current policy, although the British were in reality proceeding on the assumption that the continuing organisation would develop permanent functions, had been necessary 'to obtain the support of the Scandinavians and the Swiss'. ${ }^{2}$ The importance of keeping the neutrals within the already established forms of cooperation, while developing new ones, was great. Pushing them too hard in questions of the institutional structure of the ERP would have decreased the chances of having them to take part in other, possibly more wideranging schemes, including security aspects.

The Anglo-Scandinavian front re-emerged in a number of issues from 1948 onwards in the OEEC, such as the organisation's constitution, the personality of the secretarygeneral, and the way Marshall aid was allocated. ${ }^{3}$ As long as European economic cooperation was based on intergovernmental decisionmaking, the small powers could enjoy a relatively strong position. The British found this especially useful, provided that the Scandinavians shared their basic objectives. The Anglo-Scandinavian alliance within the OEEC provided them with much needed support in the sinking of any plans for further integration. Within the Anglo-American relationship, it was important that Britain

\footnotetext{
${ }^{1}$ af Malmborg, Den ständaktiga nationalstaten, 82.

${ }^{2}$ Bevin \& Cripps memorandum, 'European Economic Co-operation', 6.3.1948, CP(48)75, CAB 129/23.

${ }^{3}$ Milward, The Reconstruction of Western Europe, 174 - 175, 186, 193 - 194, 202 - 203.
} 
did not seem to be the only country opposing the idea of an economically integrated Europe. The more the Scandinavians, especially neutral Sweden, could do of the running, the better for British-American relations.

This convergence of interests on issues of European economic cooperation made it also easier for the British to understand the main currents behind Swedish foreign policy. While the Americans were irritated by Sweden's and Norway's hesitations about the form economic reconstruction and cooperation in Western Europe should take, the British had a better appreciation of their case. While they also were not entirely happy with Sweden's foreign policy, they saw more clearly than the Americans that their hesitations were not only due to a fear of Soviet reactions. There was a shared and genuine apprehension of a federal and supranational approach to solving Europe's problems, and this paved the way for a wider understanding between the British and the Scandinavians.

At the start of the work of the CEEC and OEEC the British could ally themselves with the French against American objectives. This support disappeared in AugustSeptember 1949, when the Americans switched their focus on developing closer cooperation with the French over European economic cooperation, now, if possible, outside the OEEC. The only support the British could then count on came from the smaller states, notably the Scandinavians. Britain was the only major power they could rely to oppose Franco-American ideas on the form of European reconstruction. ${ }^{1}$ The realisation of this made the consolidation of the Anglo-Scandinavian front even more important, as they became more and more isolated in the main questions concerning the future outlook of European economic cooperation. Meanwhile, the economic consolidation of Western Europe had been overshadowed by the birth of the Atlantic alliance, but the steps taken on the military-strategic front of the cold war in no way reduced the significance of the economic dimension in Anglo-Swedish relations.

\footnotetext{
${ }^{1}$ Milward, The Reconstruction of Western Europe, 209.
} 


\section{ATLANTIC ALLIANCE VS. SCANDINAVIAN UNITY, 1948-1949}

By the beginning of 1948 the cold war had begun to dominate the international scene. After the breakup of the Council of Foreign Ministers in London in December 1947, it was evident that the grand Alliance that had won the Second World War could not bridge differences, the most important being over the future of Germany. The time for negotiation was over. This led to an increased need to consolidate the forces in the West in economic reconstruction and in some kind of political and military alliance. At the same time, Stalin consolidated his hold of Eastern Europe.

The increasing international tension in late 1947 and early 1948 also influenced Scandinavia's position in British foreign policy. Important steps had been taken in the summer and autumn 1947, when the Scandinavians, and most notably the Swedes, had participated in the discussions in Paris about the Marshall plan. At the same time, following the conclusions reached by the COS about the strategic significance of Scandinavia, the failure of the Council of Foreign Ministers highlighted the problems in Scandinavian defence and the complications caused by Sweden's nonalignment that remained unsolved. Something more than the OEEC might be needed.

The main thread going through British Scandinavian policy during this period, was that the overriding goal of creating a Western European and Atlantic security system should be supplemented with an aim to create a system of coordinated Scandinavian defence. Coupled with the aim of keeping Norway and Denmark from withdrawing to their prewar neutrality and away from the West, was the need to further interScandinavian cooperation and unity. Herein laid the basic dilemma: how to reconcile inter-Scandinavian unity with closer ties with the West if Sweden upheld its present policy? If this could not be achieved, what advantages there were for Britain in Norwegian and Danish membership in a Western defence alliance without Sweden? 
Bevin's Western Union and Scandinavia

Faced by the situation following the breakup of the Council of Foreign Ministers, early in January 1948 Bevin presented the Cabinet with a plan in which the main idea was to harness the strength of the Western European countries in a union of some kind, following active British leadership. In a famous document titled 'The First Aim of British Foreign Policy', Bevin outlined his ideas, according to which Britain had to 'organise and consolidate the ethical and spiritual forces inherent in this Western civilisation'. ${ }^{1}$ This was to be done by 'creating some form of union in Western Europe, whether of a formal or informal character, backed by the Americas and the Dominions' ${ }^{2}$ This Western democratic system should have included Scandinavia, the Low Countries, France, Portugal, Italy and Greece. ${ }^{3}$ The whole notion of a Western Union was, nevertheless, remarkably vague and the implications to the practical execution of British foreign policy were not clear at the outset.

The discussions in the Cabinet and the following 'Western Union' speech in the House of Commons by Bevin on 22 January has been widely discussed in the historiography of the cold war and British foreign policy. ${ }^{4}$ Its implications for British policy towards Scandinavia are less well known. Nevertheless, Bevin's ideas had central importance also in Anglo-Scandinavian relations, and the fact that the reference to Scandinavia was omitted from the final version of Bevin's speech makes it even more

\footnotetext{
'Bevin memorandum, 'The First Aim of British Foreign Policy', 4.1.1948, CP(48)6, CAB $129 / 23$.

${ }^{2}$ Ibid.

${ }^{3}$ Ibid.

${ }^{4}$ For example: John Kent \& John W. Young, 'The "Western Union" concept and British defence policy, 1947-48', Richard Aldrich (ed.), British Intelligence, Strategy and the Cold war, 1945-51 (London: Routledge, 1992), 166 - 192. Bullock, Ernest Bevin, 513 - 525; Geoffrey Warner, 'The Labour Governments and the Unity of Western Europe, 1945-51', 61 - 82; John W. Young, Britain, France and the Unity of Europe 1945-1951 (Leicester: Leicester University Press, 1984), 77 - 98.
} 
interesting to find out what he thought Scandinavia's position in relation to the emerging Western bloc was.

In preliminary discussions about a Western European bloc, initiated early in 1947, Britain's closest partners in Scandinavia, Norway and Denmark, were not approached or even indirectly informed about the talks. ${ }^{1}$ While visiting London early in January 1948 , the British ambassador to Sweden saw the reference to Scandinavia in Bevin's papers, but was instructed to keep it confidential. ${ }^{2}$ One should not, therefore, assume that any of the Scandinavian countries was vital or foremost in Bevin's mind at this stage. Bearing that in mind, in December 1947 it was nevertheless thought in London that while the formation of a Western bloc was now 'an inevitable and essential object of [British] policy', then 'in relation to any such bloc Sweden occupies an important position as the leading Scandinavian power and one immediately confronting the Soviet-controlled area' ${ }^{3}$ As seen in the memorandum presented to the Cabinet on 4 January, Sweden and the other Scandinavians were originally included in Bevin's Western Union scheme. In the Cabinet Bevin specifically referred to Sweden, when he outlined Britain's 'Future Foreign Publicity Policy'. The example of social democrat countries, such as Britain, Sweden and New Zealand, was instrumental in providing the leadership 'in spiritual, moral and political sphere to all the democratic elements in Western Europe' ${ }^{4}$ In this project to maintain Britain's international position against the communist ideological challenge, Britain's 'main target should be the broad masses of workers and peasants in Europe and Middle East. We should, therefore, use the arguments most likely to appeal to them'. Living conditions in a social democratic Sweden were a useful example in this

\footnotetext{
${ }^{1}$ Skodvin, Nordic or North Atlantic Alliance?, 11.

${ }^{2}$ Ibid., 18.

${ }^{3}$ Ibid., 15.

${ }^{4}$ Bevin memorandum 'Future Foreign Publicity Policy', 4.1.1948, CP(48)8, CAB 129/23.
} 
context. $^{1}$

That the idea of a some kind of 'spiritual union' had resonance within the Parliamentary Labour Party in general was seen in the way it was interpreted in the House of Commons after Bevin's speech. The leftwing Labour MP Richard Crossman highlighted that this union should in particular be based on democratic socialism throughout Western Europe, and was remarkably enough followed by Attlee, who said that although it was up to each country to find the kind of social arrangements that suited them best, 'in all free countries of Europe today, there is a mixed economy in course of evolution, and, I believe, evolving towards Social Democracy'. ${ }^{2}$ Attlee mentioned the Scandinavian countries in particular as 'having many fine achievements to their credit' ${ }^{3}$

In a study commissioned by Bevin, Hankey endorsed the views about the importance of including the Scandinavian countries in the Western Union plan. He said that they were 'natural and desirable members of any Western Union' ${ }^{4}$ It was nevertheless acknowledged that the governments in question were prevented from making any open declaration in favour of political association with the West. The reason behind this was their proximity to the Soviet Union, which forced them to try to 'sit on the fence as long as they can'. They would find it difficult to abandon their neutrality unless given firm security guarantees from the West. ${ }^{5}$

If Bevin, the FO and his Cabinet colleagues placed importance on the inclusion of the Scandinavian countries into their plans for a Western Union, it would seem to have been logical to say so openly in public. Bevin, however, chose a different approach. His

${ }^{1}$ Ibid.

${ }^{2}$ House of Commons Debates, 5th Series, vol. 446, col. 561 - 569, 23.1.1948; Attlee's speech in the House of Commons, 23.1.1948, Attlee papers Vol. 102, Bodleian Library, Oxford.

${ }^{3}$ Ibid.

${ }^{4}$ Hankey memorandum, 'Scandinavia and Western Union', undated (January/February 1948), FO $371 / 71449$.

${ }^{5}$ Ibid. 
hesitation about including Scandinavia in his speech, or to begin talks with representatives from these countries, was in line with his previously cautious policy towards Scandinavia. One can argue that the countries mentioned in Bevin's speech were already in an informal Western bloc. Scandinavia was not, and that was one of the main reasons behind his approach.

A public reference to Scandinavian participation would have given the Soviet Union a propaganda weapon against the Scandinavian governments who were facing an electorate that had been educated to appreciate the virtues of neutrality and bridgebuilding. The very delicate balance of power in the north would have been unnecessarily upset by forcing the Scandinavians to choose sides, when it was clear they were not yet ready to do so. Even in Norway, the government would have had to face sceptical domestic opinion. If Britain was not giving concrete guarantees to these countries, a rhetorical declaration would probably have worked against British long term interests. Especially given the fragile state of Scandinavian unity, a positive Norwegian response coupled with Swedish and Danish refusals to take part in the Western Union, would have destroyed any hopes of keeping the states together and thus played straight into the Russians' hands. Bevin wanted the situation to mature, develop the promising cooperation in the ERP, and was therefore willing to wait and let the door stay open. ${ }^{1}$

The reactions in Scandinavia to Bevin's speech in the House of Commons on 22 January divided along familiar lines. The most positive reaction came from Norway, the most wary from the Swedes. Even the Norwegian response was noncommittal when it came to the potential military implications of a Western Union. ${ }^{2}$ The Norwegians had

\footnotetext{
${ }^{1}$ Bevin telegram No. 2768 to Washington, 10.3.1948, FO 371/71458; Record of Bevin's conversation with Lange, 15.3.1948, FO 800/500; McNeil explained these views to the Nordic representatives. See Wuori to Enckell, 28.1.1948, AFMFA; Boheman telegram to UD, 28.1.1948, HP $1 \mathrm{Ba}$, Vol. 241, RA.

${ }^{2}$ Skodvin, Nordic or North Atlantic Alliance?, 28.
} 
nevertheless shown more interest in building up the forces of Western Europe under some kind of common front in January 1948. In confidential discussions in Oslo on 12 January between Collier and the Norwegian Foreign Minister Halvard Lange, the latter had said that as opinion in Norway was shifting towards a departure from the official policy of bridge-building, 'every informed person in Norway now realised that a combined stand must be made against Soviet tactics if the United Nations were not to break up and Soviet aggression be allowed a free field in Europe'. ${ }^{1}$ On the same day, Lange also went public with his positive attitude towards closer Western cooperation. As reported by Collier, he said 'that Norway was ready to take part in the work of developing relations between the countries of Western Europe and to protect the democratic way of life which is common to all of us' ${ }^{2}$ At first this remark may seem cautious, but it was the first occasion when a Nordic statesman openly supported the idea of closer association with the emerging Western bloc against the Soviet threat.

In Sweden, by contrast, a programmatic government declaration, backed by Östen Undén's speech on 3 February, reaffirmed that Sweden had no intention at all of associating itself with any bloc, 'be it an explicit pact of alliance or silent understanding of common military action in the case of a conflict' ${ }^{3}$ Swedish officials tried to explain that Undén's statement was not a reply to Bevin's speech, but a part of a domestic debate over the wisdom of nonalignment. ${ }^{4}$ Nonetheless, the essence of Undén's message was what mattered in London. ${ }^{5}$ In line with the Swedish statements, the Danish prime minister deplored the creation of any blocs in his speech on 31 January and stressed the

Collier to Attlee, 15.1.1948, FO 371/71449.

${ }^{2}$ Collier to FO, 15.1.1948, FO 371/71449.

${ }^{3}$ Skodvin, Nordic or North Atlantic Alliance?, 36 - 37.

${ }^{4}$ Grafström's promemoria, 7.2.1948, HP $1 \mathrm{Ba}$, Vol. 241.

5 Jerram telegram No. 84 to FO, 5.2.1948; Etherington-Smith minute, 7.2.1948, FO $371 / 71723$. 
necessity of remaining outside them. ${ }^{1}$

A meeting of the Scandinavian foreign ministers in late February did not lead to any crystallization of a more positive approach to the concept of a Western Union. All that Undén was willing to say, was that he was prepared to consider the Bevin plan with a view to Swedish participation, on the assumption that its proposals were mainly economic. $^{2}$ With his obstinacy, Undén also prevented the Norwegians from bringing about a more positive common Scandinavian response to Bevin's ideas. For the present, the British did not think there was any advantage of seeking further discussions with the Scandinavians, at least until the plans had become clearer.

\section{Stalin's advances and naval diplomacy}

Despite this cautious line, for those who waited for the critical Soviet response towards a possible Scandinavian participation in a Western Union did not have to wait for long. The propaganda charge began on 7 February, when it was said in Moscow that 'there is now again talk in Swedish and Norwegian Right-wing circles about need for setting up a northern bloc which is considered suitable weapon by Scandinavian reactionaries for carrying out aggressive, primarily anti-Soviet schemes. A northern bloc would also be part of the western bloc serving interests of United States imperialism'. ${ }^{3}$ British representatives in Moscow interpreted the press attack as 'to serve as a useful periodic reminder to the Scandinavians that, while they are by blood and tradition bound to the West, they must never forget that geographically they are neighbours of the Soviet

\footnotetext{
${ }^{1}$ FO to British representatives in the Commonwealth, 13.3.1948, FO 371/71450.

${ }^{2}$ Collier telegram to FO, 26.2.1948; Etherington-Smith minute 27.2., FO 371/71450.

${ }^{3}$ Sir Maurice Peterson (Moscow) to FO, 8.2.1948, FO 371/71449.
} 
Union'. ${ }^{1}$

The communist coup in Prague in late February 1948 and the publication of Stalin's letter suggesting a bilateral treaty of 'friendship, cooperation and mutual assistance' to the Finnish President J. K. Paasikivi on 27 February, immediately increased Western European fears of further expansion of the Soviet sphere. In the House of Lords, Lord Pakenham said: 'And now the unhappy government of Finland are being embraced with the kiss of death and are invited to visit Bluebeard's mansion and inspect their predecessor's remains. ${ }^{2}$ In the Cabinet on 5 March, Bevin outlined the situation in very alarmist terms. He saw no limits to Stalin's aggressive ambitions. The next possible steps were anticipated in the 'direction of Italy and France', and besides Finland, 'with possibly a threat to the independence of the other Scandinavian countries' ${ }^{3}$ Concerning Czechoslovakia there was now not much that could be done, but Scandinavia was a different case. Regarding the right response by Britain, Bevin highlighted the importance of appearing 'as strong as we can, lest other friends of Great Britain (e.g., the Scandinavian countries) should be encouraged to think they must compound with the Russians while there is yet time'. ${ }^{4}$

In Scandinavia, the effect of these events was most striking in Norway, after rumours circulated that Stalin might make a similar approach to the Norwegians as he had made to the Finns. ${ }^{5}$ Despite the fact that these rumours soon proved to be a false alarm, they were at first taken very seriously in London, where for example William Hayter said in a meeting of the COS on 10 March, that 'it was likely that the Russians would make

\footnotetext{
${ }^{1}$ Chancery (Moscow) to FO, 13.2.1948, FO 371/71450.

${ }^{2}$ House of Lords Debates, 5th Series, vol. 154, col. 323. 3.3.1948.

${ }^{3}$ Bevin memorandum, 'The Czechoslovak Crisis', 3.3.1948, CP(48)71, CAB 129/25; Cabinet minutes, 5.3.1948, CAB 128/12.

${ }^{4}$ Bevin's memorandum, 'The Czechoslovak Crisis', 3.3.1948, CP(48)71, CAB 129/25.

${ }^{5}$ On these rumours, J. Raymond Ylitalo, Salasanomia Helsingistä Washingtoniin. Muistelmia ja dokumentteja vuosilta 1946-48 (Helsinki: Otava, 1978), 230 - 232; Magne Skodvin, Norden eller Nato?, 93 - 96; FO memorandum, 30.3.1948, FO 371/71447.
} 
some approach to Norway' and by doing so they would isolate Sweden and in the end bring them into their own camp. ${ }^{1}$ Assistant Under-Secretary Sir Ivone Kirkpatrick stressed the importance, but also usefulness, of the possibility of Russian pressure on Norway. Kirkpatrick, whom Bevin assigned to prepare the blue-print for a Western European alliance to be followed by an Atlantic one, said that this 'unexpected development gave a strong impulse to the conception of an Atlantic Alliance'. ${ }^{2}$ The assistance from the Soviet Union in consolidating Western resolve was not entirely unwelcome in London.

The impression gained by the Ambassador Wuori in London was that Bevin had washed his hands of Finland and the main interest was on Sweden, Denmark and Norway. ${ }^{3}$ If Finland was allowed to go, the British would nonetheless make an open dispute out of an Soviet attempt to do the same elsewhere in Scandinavia. ${ }^{4}$ Wuori's assesment, that Finnish-Soviet relations were of real concern in London only when they had an bearing elsewhere in Scandinavia, was correct.

Hoping that the Soviets would not cross this line in Scandinavia, Bevin said that the action of the Russians in forcing a treaty on the Finns was perhaps no more than evidence of their preoccupation with the consolidation of their security in that part of Europe. However, in Bevin's view the Russians might well feel that once the situation in Finland had been fully assured, the time was ripe for further progress. The implications of Britain's attempts to pull the Swedes in particular out of their shell were

\footnotetext{
${ }^{1}$ COS minutes 10.3.1948, COS(48)36, DEFE 4/11. The discussions in the COS run counter to Petersen's argument that 'there are few other indications that he [Bevin] or the FO considered the Scandinavian situation as particularly dangerous'. Petersen, 'Britain, Scandinavia and the North Atlantic Treaty 1948-49', 253. Petersen did not have access to the relevant Ministry of Defence files used here. The Finns believed that the British tried to use the Finnish example to frighten the Scandinavians off joining the West. Wuori to Enckell, 22.3.1948.

${ }^{2}$ Ivone Kirkpatrick, The Inner Circle (London: Macmillan, 1959), 206.

${ }^{3}$ Wuori to Enckell, 5.3.1948.

${ }^{4}$ Wuori to Enckell, 22.3.1948.
} 
still very unclear. Bevin said about Sweden, that it was 'at present hovering between her obvious affinities with the West and her traditional policy of neutrality, and the Russians may feel that it is necessary to make a determined effort now to prevent the Swedish Government from leaning more towards the Western Union' ${ }^{1}$ On the other hand, opinion in Norway was hardened considerably against the communists.

Without a firm American promise for a European strategic commitment, this was a frustrating period for the British. The way they initially planned to show their intentions regarding Scandinavia at this stage, illustrated well these frustrations, but also their rather desperate situation. Soon after the news from Prague and Helsinki had been received, a suggestion was made, that Britain, as a countermeasure in northern Europe, should use one of its traditional means of showing political and military muscle: naval exercises and visits.

The initiative for 'naval diplomacy' came from the COS, who were asked by the FO to prepare an assessment of the situation in Finland. Rear Admiral G. N. Oliver, the assistant chief of the naval staff, said that in his opinion 'his concern ... was not so much for Finland - which he considered was bound to fall under Russian domination sooner or later - as for the other Scandinavian countries'. ${ }^{2}$ From the military point of view, the position of Finland had no great effect on British strategic interests, 'but the importance of her future lies in the effects on the Scandinavian countries' ${ }^{3}$ If Finland fell under Soviet pressure without any material encouragement to resist from the Western powers, the effects on Sweden, Denmark and Norway 'would be deplorable'. ${ }^{4}$ Oliver suggested that to strengthen the Scandinavians' will to resist Soviet pressure, a naval task force should carry out exercises in Scandinavian waters. Oliver was making preparations to this

\footnotetext{
${ }^{1}$ Ibid.

${ }^{2}$ COS minutes, 28.2.1948, COS(48)29, DEFE 4/11.

${ }^{3} \mathrm{COS}$ to FO, 28.2.1948, COS 339/27/2/8, DEFE 4/11.

${ }^{4} \mathrm{COS}$ minutes, 28.2.1948, COS(48)29, DEFE 4/11.
} 
end under the direct instructions of the first sea lord, Admiral Sir John Cunningham. A gesture of similar kind had been 'most effective in Persia'. ${ }^{1}$ Sir James Robb, the vice chief of the air staff added, that some air units might take part in the exercises.

The composition of the forces to take part in these exercises was to be two battleships, a fleet carrier and a large number of minor vessels: thus a major naval task force even in Royal Navy terms. ${ }^{2}$ Probably visualizing the sight of the Royal Navy heading full steam into a collision with the Soviets in the Baltic, Etherington-Smith, who was at the meeting as the FO representative, urged caution when dealing with the situation in Finland. The FO view was that it was far from clear that the Russians intended to gain complete domination of Finland. The show of British military strength in Scandinavia might lead them to take measures they would not otherwise take, and provoke them to bring things to a head. This would run counter to the FO line that had been to keep the cold war away from Finland and to avoid provocative action which might lead the Russians to apply more pressure in that direction. ${ }^{3}$ Lieutenant-General G. W. R. Templer brushed these considerations aside by saying that there was no doubt that the Russians would dominate Finland sooner or later. He considered their aim was to get hold of the communications in northern Norway. Templer thought that the gesture proposed by the navy would have little effect in Finland, but it would have 'excellent effects in Sweden, Norway and Denmark'. ${ }^{4}$

COS thinking in 1948 ran parallel with the precedent of 1939-40, when during the 'Phoney War', Britain prepared to send an expeditionary force to fight the Russians in Finland. In 1939-40 the ultimate objective had been to bring Norway and Sweden on to the allied side. Another objective had been 'to do something' in an otherwise uneventful

\footnotetext{
1 Ibid.

${ }^{2}$ Hayter minute, 24.3.1948, FO 371/71447.

${ }^{3}$ COS minutes, 28.2.1948, COS(48)29, DEFE 4/11.

${ }^{4}$ Ibid.
} 
war. Both these considerations applied in 1948 as well. The cold war had reached a state analogous to the 'Phoney War', and the COS minutes from the spring 1948 reflect the widespread frustration amongst the military planners. Something had to be done to demonstrate where the British COS thought their vital interests were at stake, but where and how was not for them to decide.

The British ambassadors in Scandinavia supported the COS proposal. In a meeting on 12 March between Bevin, the Minister of Defence A. V. Alexander, and the representatives from the Admiralty, the plans were outlined. There was of course the danger that the Soviets might retaliate by military or naval occupation somewhere in Scandinavia and call Britain's bluff, but this risk was thought worth taking. It was considered unlikely that the Soviets would risk a naval encounter either in the northern waters or the North Sea.

However, the realities of British military overstretch were only too evident. As the first sea lord explained: 'It would be difficult to mount at once a task force which would be really impressive without dislocating all the plans for training, leaves and as this would soon become known, this would reveal the fact that the Admiralty was only able to undertake this exercise by sacrificing the general efficiency of the Navy'. ${ }^{1}$ The heavy sacrifice of the operation inflicted in training, maintenance and overseas relief had already on 1 March been conveyed to the FO by the COS. ${ }^{2}$ Thus a show of strength in the Scandinavian waters might end up as being a show of a remarkable weakness. If the exercises could be postponed until May, then these problems would not be as evident. Even general knowledge that such a fleet was being prepared to visit Scandinavian waters was thought to have a great psychological effect. But as Alexander, said, it might just as well happen that in the meantime, 'our inherent weakness would be gradually revealed

\footnotetext{
' Sargent minute, 12.3.1948, FO 371/71447.

${ }^{2} \operatorname{COS}$ minutes 1.3.1948, COS(48)30, DEFE 4/11.
} 
by questions in Parliament and mischievous comment in the Press'.

In further discussions between Attlee and Bevin at Chequers on 14 March, no decisions were made about the proposed naval demonstration. ${ }^{2}$ In discussions with Alexander, Attlee elaborated his views about the extent of the publicity of a possible operation by saying that 'no special announcement should be made', and that normal training operations should take place without formal naval visits to Scandinavian ports. ${ }^{3}$ Attlee was thus implying that not too big an issue should be made out of the Scandinavian question.

As advised by the first sea lord, orders were then issued for the exercises to be carried out in May, without visits to Kiel or to Scandinavian ports. In the FO's view, this delay, combined with Attlee's wish for a low profile for the project, destroyed the original idea. The whole point of the naval demonstration in FO's view was that if it was decided to go ahead, it should have happened at the right moment and that it should have then been given wide publicity. It should also have included a visit to Kiel, because of 'the tonic effect which such a visit would be likely to have on Swedish opinion' ${ }^{4}$ The publicity campaign should have started, as Sargent put it, before 'the Russian[s] turn on the heat in Norway'. ${ }^{5}$ It was then or in the very near future, and not in May, that the FO wanted 'to strengthen Scandinavian morale'. ${ }^{6}$ But Bevin, in line with other ministers involved, did not want to divert resources to Scandinavia now, at the expense of other considerations in the navy. ${ }^{7}$ Due to inadequate naval preparations, and the fear of provoking the Soviet Union, the whole exercise was then postponed indefinitely, and as

\footnotetext{
${ }^{1}$ Ibid.

${ }^{2}$ Sargent to Alexander, 15.3.1948, FO 371/71447.

${ }^{3}$ Alexander minute, 17.3.1948, FO 371/71447.

${ }^{4}$ Hankey minute, 26.3.1948, FO 371/71447.

${ }^{5}$ Sargent to Alexander, 15.3.1948, FO 371/71447.

${ }^{6}$ Hankey minute, 26.3.1948, FO 371/71447.

${ }^{7}$ Hankey minute, 14.4.1948, FO 371/71447.
} 
the possible Soviet threat to Norway became less urgent during the spring 1948, the question receded into the background.

Political considerations were also against 'naval diplomacy', especially in the Baltic Sea. The Finns themselves advised against this, in order not to provoke the Soviet Union any further. ${ }^{1}$ The FO had, further, been against extending the planned naval exercises to the northern Baltic. ${ }^{2}$ In May the possibility of sending a naval force to visit some Finnish ports was brought up again by the British ambassador in Helsinki, Mr. Scott, but received a cool response in London. In the end, Bevin himself put the whole episode of planned naval diplomacy in the Baltic to its end by minuting in May, that the idea of naval visits to Finland was 'a very unwise proposal. The Finns might say yes, so as to show their independence, but when we had created the trouble for them, we then come home $\&$ abandon them to the pressure of Russia'. ${ }^{3}$

\section{Western security and Scandinavian unity}

If it became so acutely clear that Britain alone could not meet the Soviet challenge even in such a limited sector such as showing its naval strength in the northern waters, events from February onwards gave Bevin's ideas for a Western Union even more urgency. Now the original idea of the Western Union had to be expanded from the 'original friendly intent of our more limited approach' to a wider concept of Western security arrangement. ${ }^{4}$

${ }^{1}$ Nevakivi, Maanalaista diplomatiaa, 97.

${ }^{2}$ Bateman to Peterson, 24.3.1948, FO 371/71447.

${ }^{3}$ Bevin minute, 14[?].5.1948, FO 371/71448A.

${ }^{4}$ Bevin memorandum, 'The Threat to Western Civilisation', 3.3.1948, CP(48)72, САB $129 / 25$. 
After rumours about possible Soviet moves in Scandinavia and British exploration of the feasibility of naval diplomacy in the north, Bevin's next step was to take the issue of an Atlantic security system to the Americans. The possibility of a Russian approach to Norway provided him with a good case, as they were more concerned with the strategic implications of a Russian advance in Norway than in Czechoslovakia. On 11 March the British delivered an aidé memoire to the State Department about the situation in Norway. ${ }^{1}$ Playing up the Norwegian question, Bevin wrote to Marshall that to halt 'the relentless advance of Russia into Western Europe' and 'in view of the imminent threat to Norway, we should study the establishment of the Atlantic security system without any delay'. ${ }^{2}$ Marshall agreed that immediate discussions should begin. ${ }^{3}$ These started on 22 March in Washington. The increasing tension also brought new hopes about linking the Swedes more closely with the West. British diplomats observed with some pleasure their increasing fear about Soviet intentions. They expected that the attitude of all the Scandinavian governments as regards Western Union might change considerably because of these developments. ${ }^{4}$

Undén's conversations with the British diplomats in Stockholm, nevertheless, did nothing to justify these hopes regarding Sweden. When asked whether the recent events were likely to bring about any change in Sweden's policy, Undén replied that there was no change but that 'Sweden would of course keep her eyes open with regard to the carrying out of possible Communist tactics in Sweden'. Having said that, Undén emphasised, that 'it would be disastrous however, if Russia got the impression that

${ }^{1}$ Lundestad, America, Scandinavia, and the Cold War, 178.

${ }^{2}$ Bevin telegram No. 2768 to Washington, 10.3.1948, FO 371/71458; Report by the JPS, 17.3.1948, JP(48)28(FINAL), DEFE 4/11.

${ }^{3}$ Marshall to Lord Inverchapel, 12.3.1948, FRUS 1948, Vol. III, Western Europe (FRUS) (Washington: Government Printing Office, 1974), 48.

${ }^{4}$ Etherington-Smith minute, 27.2.1948, FO 371/71450; FO memorandum, 30.3.1948, FO $371 / 71447$. 
Sweden might be used as a base for attacks upon Russia'. ${ }^{1}$ When the British ambassador queried Undén's responses to the developments in Czechoslovakia, he 'could only express his surprise at what had happened there and his ignorance as to what could have led to it in a democratic country'. ${ }^{2}$ Undén's appreciation of the situation in Finland, by contrast, was more in line with British thinking: as 'regards Finland M. Unden said that a military alliance between Finland and the Soviet Union would be disagreeable to Sweden; but had regarded Finland in any case as within the Russian orbit' ${ }^{3}$

Undén's reactions remained very consistently on familiar neutralist lines. The developments in February and March 1948 again made it abundantly clear to the British that as long as Undén was in charge, fundamental changes in Swedish foreign policy would be highly unlikely. Not even the worsening of Finland's situation would move him. In addition, British diplomats with first hand experience of dealing with Undén were frustrated by the impossibility of establishing anything more than the most distant and formal of relationships with him. James Henderson, the chargé d'affaires in Stockholm, described one of his encounters with this 'most unresponsive person':

He sits on a sofa and stares mutely at his interviewer who, in self-defence, is driven to make suggestions as to what he may or may not be thinking. He sometimes answers 'Umm' and sometimes he doesn't answer at all, and the speaker may take this as agreement or disagreement according to whether he is an optimist or not. ${ }^{4}$

And when the supreme guardian of Sweden's neutrality policy did allow impressions to be created not only from his silence, British diplomats had to interpret them as if they

\footnotetext{
' Jerram to FO, 28.2.1949, FO 371/71450.

${ }^{2}$ Jerram telegram No. 152 to FO, 28.2.1948, FO 371/71723.

${ }^{3}$ Ibid.

${ }^{4}$ Henderson to Hankey, 23.4.1948, FO 371/71724.
} 
were 'utterances of the Delphic Oracle'.'

The Danes in contrast were stiffening their attitude towards Stalin, and in a speech by the Danish finance minister on 2 March the developments in Prague were likened to the period before $1939 .{ }^{2}$ The increasingly clear division of the world also made the Finnish ambassador in London observe that public opinion in Britain was becoming less and less understanding towards neutrality as a legitimate option for the minor powers. ${ }^{3}$ The British press made increasingly critical comments about neutrality in the present world situation. ${ }^{4}$ This was highly relevant concerning Scandinavia. It seemed that the chances for neutrality diminished week by week.

Ever since 1946, there had been two conflicting trends in British Scandinavian policy. First, there was a need to treat Scandinavia as a whole and to pursue policies that would strengthen Scandinavian unity. This would require long negotiations and reconciliation of the different views of the British and the Scandinavians themselves, but on this point there was a consensus between the FO and the COS. Second, this line was challenged by a more Atlantist approach, where close Anglo-Norwegian relations were considered as the most important issue, and to this end other British interests in Scandinavia might have to be sacrificed. The major proponent of this view was the wartime head of the Northern Department, now the ambassador in Oslo, Sir Lawrence Collier.

After Bevin's Western Union speech and the events in February, the division between these two views became more acute, as Scandinavian unity seemed to require more concessions from the British than they might be willing to make in the new situation. The question was whether Britain should try to bring into a Western system those

${ }^{1}$ McKenzie Johnston minute, 9.2.1948, FO 371/71723; Henderson to Hankey, 23.4.1948, FO $371 / 71724$.

${ }^{2}$ FO telegram to British representatives in the Commonwealth, 13.3.1948, FO 371/71450.

${ }^{3}$ Wuori to Enckell, 22.3.1948.

${ }^{4}$ Wuori to Enckell, 24.3.1948. 
Scandinavian countries who were willing to do so now, leaving Sweden out in the cold, and thus sacrificing such advantages as inter-Scandinavian cooperation might provide. Or should Britain wait until all three countries were prepared to come in? ${ }^{1}$

As Sweden showed no signs of giving up its previous policy, Collier, now cautiously supported by Jerram from Stockholm, urged that 'as soon as we have got out "Bevin Pacts" with France and Benelux countries finally fixed up, we should begin to work discreetly for a similar pact with Norway without approaching Sweden or Denmark at the same time'. ${ }^{2}$ Collier soon modified his views relating to Denmark, and said, that 'our hopes ... must now be centered ... on getting Norway, and perhaps ultimately Denmark to enter the Western bloc, with a guarantee of firm Swedish neutrality to protect their eastern flanks. To expect anything beyond that, in the foreseeable future at least, is, I fear, wishful thinking' ${ }^{3}$

The ever present danger of Scandinavian isolationism was Collier's main fear, and in his view Scandinavian unity would inevitably increase this trend. ${ }^{4}$ Neither was Collier convinced about the indispensability of Sweden as a part of Scandinavian defence, as 'the key to the defence of Denmark is surely in Germany, while the key to the defence of Norway lies in adequate and early support from the West'. ${ }^{5}$ Collier nevertheless could not deny the fact that 'in both cases it would be essential that the Swedes would be determined to defend their neutrality and to refuse to allow it to be biassed against us' ${ }^{6}$

Jerram's interpretation of Britain's policy towards Scandinavia followed Collier's line: encourage Norway and Denmark to align themselves with Western Union in some form;

\footnotetext{
${ }^{1}$ Jerram to Hankey, 2.3.1948, FO 371/71723; Etherington-Smith minute, 7.4.1948, FO $371 / 71451$.

${ }^{2}$ Collier to Hankey, 8.3.1948, FO $371 / 71450$.

${ }^{3}$ Collier to Randall, 12.3.1948, FO 371/71451.

${ }^{4}$ Ibid.

${ }^{5}$ Ibid.

${ }^{6}$ Ibid.
} 
and hope that their affiliation may at the right moment encourage and attract Sweden. ${ }^{1}$ At the same time Britain should encourage the Norwegian and Danish military authorities to continue to make common defence plans with Sweden, even if this was complicated by Sweden's neutrality policy.

Etherington-Smith, one of the officials in the Northern Department was not, however, completely convinced that the Swedes were beyond hope, as 'there had been a few indications that the Swedes may not prove quite as intractable as had been feared'. ${ }^{2}$ Etherington-Smith said that Collier's views on the prospects of Swedish collaboration with the West were 'unduly pessimistic'. ${ }^{3}$ Randall in Copenhagen was also against breaking Scandinavian unity by encouraging Norway alone to join ranks with the West. In his view, the only reason for doing so was as means of putting pressure on Denmark and Sweden, but without a joint Anglo-American guarantee, these countries would probably be more open 'to whatever diplomatic pressure the Russians chose to exert' ${ }^{4}$ Thus, according this view, Norway's open abandonment of its neutrality would at this stage have brought more problems than benefits.

The 'increased Soviet menace' which had exposed the Scandinavian countries to more Soviet pressure than ever before, was now creating pressure for a re-assessment of British policy. While still upholding the principle of keeping the Scandinavians together, the FO line was that a closer alignment between Scandinavia and the West was now 'highly desirable in the interests of both parties'. ${ }^{5}$ The composition of a Western Union was also now more and more linked with the question about an Atlantic Pact. In COS view, 'every effort should be made to include Sweden since the defence of Scandinavia

\footnotetext{
1 Jerram to Hankey, 30.3.1948, FO $371 / 71451$.

${ }^{2}$ Etherington-Smith minute, 20.3.1948, FO 371/71450.

${ }^{3}$ Etherington-Smith minute, 26.3.1948, FO 371/71451.

${ }^{4}$ Randall to Hankey, 17.3.1948, FO 371/71451.

${ }^{5}$ FO memorandum, 30.3.1949, FO 371/71447.
} 
should be treated as a whole'. ${ }^{1}$ But how could this be reconciled with closer ties to the West?

The conflict between these two views was the ongoing source of debate throughout 1948 and beyond. As an illustration of the gradually hardening attitudes at the lower official level in the FO, Etherington-Smith began in April to modify his attitude towards maintaining Scandinavian unity by any cost. He minuted that perhaps Britain should work 'to create a core of resistance to Soviet aggression in Scandinavia within the limits possible at present', thus leaving Sweden out at the moment. ${ }^{2}$ The assistant undersecretary in charge of the Northern Department, C. H. Bateman, however, maintained his opposition to this line, and said that Britain should not encourage Norway or Denmark to join a Western bloc. ${ }^{3}$ For the time being, at least, the hawks were kept at bay and there was no change in the established policy of putting Scandinavian unity first.

This was confirmed in Bevin's conversations with his Scandinavian colleagues in Paris in mid-March 1948. Lange stressed, that while Bevin should try to sell the idea of the Western Union to the Swedes and to the Danes, neither the US nor the British should do anything that might split Scandinavia. It was important not to force the pace with the Danes and Swedes. The Norwegians at this stage still saw their fortunes linked with the other Scandinavian countries, which made it more difficult for them to have a completely independent policy towards the British and the US. ${ }^{4}$ Bevin replied that all this had been precisely the reason he had avoided mentioning Scandinavia in his speech in January. There might, however, be a possibility of unilateral security guarantees from the US president. But in order to give security guarantees, secret military talks should take

\footnotetext{
${ }^{1}$ Report by the JPS, 17.3.1948, JP(48)28(FINAL), DEFE 4/11.

${ }^{2}$ Etherington-Smith minute, 7.4.1948, FO 371/71451.

${ }^{3}$ Bateman minute, 9.4.1948, FO 371/71451.

${ }^{4}$ Bevin to Collier, 15.3.1948, FO 800/500.
} 
place, to avoid a situation similar to the complete unpreparedness of $1940 .^{1}$

In his conversation with the Danish Foreign Minister Gustav Rasmussen, Bevin found Rasmussen more reserved than his Norwegian colleague about the prospects of joining a Western alliance. ${ }^{2}$ He said to Bevin that he did not think it was a good idea to offer Denmark a military alliance now. When Bevin asked how a unilateral guarantee given by the US president would be received by the Danes, Rasmussen strongly supported it. If Denmark joined a Western European bloc, on the other hand, this would not be enough for its military security. Bevin agreed, and said that he was very hesitant of giving any kind of guarantees the British might not be able to fulfill in practice. As with the Norwegians, Bevin stated the importance of secret military planning contacts to provide such help in the future. ${ }^{3}$

The intimate tone in Bevin's conversations with Lange and Rasmussen contrasted with the more reserved, but also friendly atmosphere in Bevin's discussions with Undén. While with Lange and Rasmussen Bevin had spoken freely about the latest developments in European-American security matters, the discussion with Undén was more general. ${ }^{4}$ When Bevin asked for Undén's opinion about a likely reaction in Sweden if the US was to give a unilateral guarantee for the Scandinavian countries, Undén did not reject the idea, but preferred that such an statement should be made in rather general terms, without explicitly mentioning Scandinavia. ${ }^{5}$

Undén's interpretation of the results of his conversation with Bevin was that Bevin had not urged Sweden to change its policy. ${ }^{6}$ It was true that Bevin carefully avoided explicitly challenging Undén's views, but he undoubtedly tried to influence Undén's

\footnotetext{
${ }^{1}$ Ibid.

${ }^{2}$ Bevin to Randall, 16.8.1948, FO 800/500.

${ }^{3}$ Ibid.

${ }^{4}$ Bevin to Jerram, 16.3.1948, FO 800/500.

${ }^{5}$ Ibid.

${ }^{6}$ Helge Jung's diary, 31.3.1948, Krigsarkivet, Stockholm.
} 
thinking about the world situation and thus bring Sweden more in step with the West. Undén was nevertheless a skillful politician and diplomat, who dressed his refusal to abandon Sweden's strict nonalignment. Undén also saw how much of a restraining influence the British might be able to exert in the West, if pressure towards Swedish neutrality grew. He said to Jerram in Stockholm that he had been very glad to meet Bevin and referred, with America in view, 'to Great Britain's vast experience in diplomacy and to her tact and delicacy'. ${ }^{1}$

Bevin's hints to Lange and Rasmussen, that the West was not planning to leave the Scandinavian countries alone, might at first seem to lack in any concrete foundations. On what grounds was he - as Britain's and not the US foreign secretary - making suggestions that the Americans would guarantee Scandinavia unilaterally? Bevin's remarks were, nevertheless, based on common Anglo-American understanding, even if this was still embryonic. Later in March the Director of the State Department's Office of European Affairs, Jack D. Hickerson confirmed this with the British diplomats in Washington, when he said that in exchange of rights for US bases in Greenland they were willing to give 'some American assurance of support to Scandinavian countries in an emergency'.?

Bevin's discussions in Paris with the Scandinavian foreign ministers did not have any immediate effect in bringing them closer to the Western Union as a bloc. At a meeting in Stockholm on 18 March the Scandinavian prime ministers only announced their intention of fighting communism within their own frontiers. ${ }^{3}$ Erlander's words were exceptionally hard against communism, but no reference was made to Western Union. ${ }^{4}$ Nevertheless, Scandinavian unity began soon to falter, as the Danish premier joined the Norwegians in giving indications of willingness to participate in Western Union 'if such

\footnotetext{
1 Jerram to Bevin, 25.3.1948, FO 371/71451.

${ }^{2}$ Washington telegram to FO, 25.3.1948, FO 800/500.

${ }^{3}$ FO memorandum, 30.3.1948, FO 371/71447.

${ }^{4}$ Jerram to FO, 19.3.1948, FO 371/71451.
} 
an association could be shown to offer them a measure of security'. ${ }^{1}$ In Sweden, the British saw signs that public opinion was turning in favour of alignment with the West. Undén's statements were nevertheless firmly against Sweden's joining any political or military blocs. All he said was that Sweden was ready to 'consider', and might be prepared to participate in Western Union on the assumption that the proposal was 'mainly' economic. ${ }^{2}$

By the end of March the British attitude towards Scandinavian participation in Western Union followed Bevin's previous line, that it was up to each country to decide 'how it can best contribute to the common cause', thus acknowledging the special difficulties with which the Scandinavians were confronted. ${ }^{3}$ Bevin also highlighted the need for an organic approach to Western unity. The consolidation of forces in the West was not just about defence, and Bevin explained that 'I am doing my best to get the Western countries together on a sound basis, not merely in connexion with defence but to get a good social and economic foundation as well on which to build for a coordinated effort which will not only bind us together to defend ourselves but give us something to defend. That is my object' ${ }^{4}$ This also opened an alternative angle on to the problem of neutrality. Falling short of defence cooperation, a neutral like Sweden could in principle take part in such cooperation aimed at the consolidation of the home front and henceforth implicitly become a part of the wider concept of the West, as defined by the cold war.

The period between April and June was marked by fluctuating uncertainty about the possibility of harnessing American military power in the defence of Western Europe. On the credit side, Britain, France, Belgium, Holland and Luxembourg signed the Brussels

\footnotetext{
${ }^{1}$ FO memorandum, 30.3.1948, FO 371/71447.

${ }^{2}$ FO memorandum, 12.3.1948, FO 371/71451.

${ }^{3}$ FO memorandum, 30.3.1948, FO 371/71447.

${ }^{4}$ Ernest Bevin to F. J. Bellenger, 31.3.1948, Bevin papers, II, 6/5, Churchill College, Cambridge.
} 
Pact on 17 March, including pledges of mutual defence. In the negotiations leading to the Brussels Treaty, the Scandinavian question had been widely debated and in the end most of the criticism to widening the group to the north had come from the Benelux countries. ${ }^{1}$ Bevin was not the only European statesman with the ultimate aim of involving the US in Western European defence. The Belgian Prime and Foreign Minister PaulHenri Spaak shared this vision. ${ }^{2}$ In contrast to Bevin's views, Spaak did not share the view about Scandinavia's political or strategic importance. This was also the French line, both in the discussions for the Brussels and North Atlantic Treaties. If the Scandinavians were brought in, it would have meant for the Benelux countries that the already limited resources would have been shared among more recipients, and also that the political influence of the small powers would have been shared more widely.

By the middle of April, the idea of including all or some of the Scandinavian countries in the Brussels Pact, was finally dropped in London. The extension of the Pact was slowly being replaced by the idea of a wider Atlantic security system, but the problem what to do with the Scandinavians remained unsolved. Norwegian adherence in a Western security system would only be achieved by breaking fragile Scandinavian unity, still a major consideration in both the FO and among the COS. Until the Americans made up their minds, the British had no material means to encourage the Scandinavians publicly to abandon their nonalignment.

Consequently, Collier in Oslo was instructed to 'go slow' regarding the wider Atlantic system. ${ }^{3}$ Gladwyn Jebb agreed that it was unwise to apply pressure on the Scandinavian states to join the Five Power (Brussels) Treaty, but he still thought Britain should do whatever it could to 'encourage' those states to adhere to it, even if it was a remote

\footnotetext{
${ }^{1}$ Bateman minute, 9.4.1948, FO 371/71451.

${ }^{2}$ Lundestad, America, Scandinavia, and the Cold War, 172.

${ }^{3}$ Bateman minute, 9.4.1948, FO 371/71451.
} 
possibility given the lack of a US clear military commitment in Europe. ${ }^{1}$ In Jebb's view Scandinavia played an important role in the Atlantic debate. American policy-makers were keen on an early extension of the Brussels Treaty to include the Scandinavians, since this might do more than anything else to convince Congress that the Western European States were prepared to cooperate among themselves, 'and hence induce the Senators to think that Western Europe is something which can legitimately receive a promise of real military support from America'. ${ }^{2}$ If all or some of the Scandinavian countries were brought in in some form or another, this willingness and ability of Western Europe to pool its own resources would have been made even more clear. ${ }^{3}$ Nevertheless, Bevin's line concerning this debate followed earlier views, that 'irrespective of the news of the Benelux Countries, there is surely no point in encouraging the Scandinavians to adhere until the position is much clearer' ${ }^{4}$ In the meantime, the Americans were asked not 'to produce any sort of pressure on the Scandinavian countries'.5

The Swedish attempt to grab the initiative

In late April and early May, pressure for closer Scandinavian attachment, if not with the Brussels Pact then with the emerging Atlantic alliance grew. Pressure also grew for Scandinavian unity. At this point the Swedes took the initiative by proposing

' Jebb minute, 16.4.1948, FO 371/71451.

${ }^{2}$ Ibid.

${ }^{3}$ Policy Planning Staff Report, 'The Position of the United States with respect to Western Union and related problems', 23.3.1948, PPS 27, FRUS 1948, Vol. III, 61 - 64. Turner, Britain, the United States and Scandinavian Security Problems 1945-49, 256.

${ }^{4}$ Bateman minute, 17.4.1948, FO 371/71451.

${ }^{5}$ Bateman minute, 9.4.1948, FO 371/71451. 
Scandinavian defence talks on the basis of neutrality and non-association with the West. ${ }^{1}$ This led at first to a critical response in London. As progress towards an Atlantic security arrangement was now well underway, the Swedish proposal for a neutral Scandinavian defence union (SDU) caused complications. How would the Americans react, if it appeared that the Europeans were now consolidating their forces under the banners of neutrality? A neutral Scandinavian bloc ran counter to British, and now also American plans to pull the Scandinavians into a closer military association with the West. Despite the fact that the policy outlined in 1947 of favouring Scandinavian cooperation was still in force, the prospect of severing Denmark's and Norway's links to the West could not be accepted in London. ${ }^{2}$ However, a Scandinavian defence pact might be the easiest immediate answer to the problem of Scandinavian defence. The problem was how to reconcile these two different goals.

In May 1948, Hankey proposed that in the light of Sweden's apparently obstinate position, perhaps a case could be made for using the supply of armaments as a political weapon against them. ${ }^{3}$ Sargent was also in favour of increasing political pressure to the Swedes. No modern radars or night fighters should be sold to the Swedes, as these weapons might at least in theory be used against British air forces on their way to targets in the Soviet Union, which cut directly across Swedish airspace. The COS agreed and suggested that Sweden's high place in the category for the supply of British military equipment should be reviewed, although strong economic considerations spoke in favour

1 On the Swedish SDU proposal, Thorsten Borring Olesen, 'Brødrefolk, men ikke våbenbrødre - diskussionerne om et skandinavisk forsvarsforbund 1948-49', Den jyske Historiker Nr. 69-70 (1994), 151 - 178; Molin, Omstridd neutralitet, 55 - 62; Aalders, 'The Failure of the Scandinavian defence union', 125 - 153; Krister Wahlbäck, 'Sverige och det skandinaviska försvarsförbundet: Sju förklkaringsfaktorer', Due-Nielsen et al. (eds.), Danmark, Norden og NATO, 45 - 57.

${ }^{2}$ Brief on Anglo-Danish relations to Attlee, 24.5.1948, FO 371/71370.

${ }^{3}$ Turner, Britain, the United States and Scandinavian Security Problems 1945-49, 209 - 210. 
of continuing the sales of advanced military technology to Sweden. ${ }^{1}$ Pending further decisions, all further deliveries to Sweden were temporarily suspended in late May $1948 .^{2}$

While this more hawkish mood was simmering on the official level, Bevin himself intervened and ordered that there should be no change in the policy of supplying arms to Sweden. ${ }^{3}$ As before, and despite displeasure of Undén's activities, Bevin believed that slow persuasion rather than pressure would bring better results. 'He saw no reason at all to modify our policy of helping Sweden to obtain armaments and military supplies', the $\mathrm{COS}$ and the FO were instructed, and Bevin continued that he 'had confidence that the Swedes would stand up to the Russians in case of need, and he wished them to be strong enough to do so'. ${ }^{4}$ The reasons behind Bevin's intervention also concerned the question of Scandinavian unity. Putting pressure on Sweden at this stage would have made it even more difficult to facilitate the formation of a kind of Scandinavian defence pact, which might later be linked with Western security arrangements.

This moderation, however, on Bevin's part did not mean that Sweden's policy was not criticised in London. The SDU proposal also tested Bevin's patience with Undén. In conversations with Scandinavian diplomatic representatives in London in late May, both Hankey and Sargent expressed their concern over the direction in which Sweden appeared to be leading these countries. To Boheman, they criticised strongly Sweden's attitude, which in their view was to draw Norway and Denmark away from the cooperation that was emerging in the West. ${ }^{5}$ Boheman told Undén that this represented a marked change in British policy towards Sweden, that had previously been 'more understanding to Swedish viewpoints' ${ }^{6}$

\footnotetext{
${ }^{1}$ COS minutes, 28.5.1948, COS(48)73, DEFE 4/13.

${ }^{2}$ Etherington-Smith minute, 27.5.1948, FO 371/71716.

${ }^{3}$ COS minutes, 16.7.1948, COS(48)101, DEFE 4/14.

${ }^{4}$ J. K. Roberts minute, 29.5.1948, FO 371/71716.

${ }^{5}$ FO telegram No. 341 to Stockholm, 22.5.1948; Hankey minute 22.5.1948, FO 371/71724.

${ }^{6}$ Östen Undén's promemoria, 1.6.1948, HP $1 \mathrm{Ba}$, (original in HP $20 \mathrm{D}$ ), Vol. 242.
} 
Boheman also knew that Hector McNeil had warned the Danish ambassador not to follow Undén's call and had told the Norwegian ambassador that British supplies of arms to Sweden might become dependent on Sweden's future orientation. ${ }^{1}$ Ambassador Collier in Oslo also spoke along these lines. Defence Minister Alexander nonetheless softened the British stance in discussions with Norway's Under-Secretary of Defence Dag Bryn, and explained that Scandinavian defence cooperation was valuable as such and that there was nothing against it in principle. But, as Assistant Under-Secretary Michael Wright from the FO explained, Bevin's view was that to give predominance to the Swedish proposal at the present delicate situation was not wise, as it implied that the Soviet Union had managed to drive a wedge between the Western powers. ${ }^{2}$

The fundamental aim of keeping the Scandinavian countries together in the emerging bloc structure thus did not disappear from Bevin's policy, but the situation where Sweden appeared to be luring Norway and Denmark into strategic and political isolation was not acceptable. Bevin stressed to Boheman the understanding that had been reached with Undén in Paris in March, that Britain had no wish to press Sweden into closer Western cooperation against its will. But this could not be interpreted as to allow Sweden, 'the strongest country in the North', to press Norway and Denmark to 'loosen their friendship with England'. If Sweden wanted to stay aloof militarily, that was understandable, but it was another thing to give the Soviets any propaganda victories. 'Cooperation with Scandinavia and Britain and with other countries will with time grow wholly naturally. I do not want to hurry anybody but do not shut the doors!' ${ }^{3}$ Without a hint of 'his normal joviality', Bevin explained to Boheman:

I want as long as possible to avoid to polarise the situation against Sweden. But

\footnotetext{
' Boheman's telegram till UD, 5.6.1948, ibid.

${ }^{2}$ Undén's promemoria, 7.6.1948, ibid.

${ }^{3}$ Boheman's telegram to UD, 18.6.1948; Boheman to Undén, 18.6.1948, ibid.
} 
in a recent meeting of Labour's parliamentary group I was confronted with questions of Sweden's position. In my party we have always been for Sweden, although you were neutral in the war. ... But now attitudes here started to become bitter. Perhaps Sweden could follow its policy without giving the impression that it is working against Western Europe's consolidation ... It is the right psychological atmosphere in Swedish policy that we miss ... You belong after all to the Western world, don't you? ${ }^{1}$

Boheman told Undén that towards the end of the conversation, Bevin's mood improved somewhat, and that he seemed to be content with Boheman's assurances that Sweden would not put pressure towards Norway and Denmark. Boheman also stressed to Bevin the connection between the approaching September elections in Sweden and Undén's initiative. ${ }^{2}$ According to Boheman, and in line with his longstanding 'molework' against Undén's policy, not too big an issue should be made of the SDU proposal and he agreed with Bevin that 'Sweden's attitude might safely be described as Western' ${ }^{3}$ If that was the impression Boheman conveyed to Bevin, the message he sent to his political masters in Stockholm was that the British government were not trying to put pressure on Sweden either. However, the perceptive Eero A. Wuori observed that in official circles in Britain a view of Swedish neutrality had been formed that after joining the ERP, Sweden was not in fact as neutral as it would like to think. ${ }^{4}$ The Americans, by contrast, thought otherwise.

At the time of Freeman 'Doc' Matthews's appointment as ambassador to Stockholm

${ }^{1}$ Ibid.

2 Matthews telegram to Marshall, 21.6.1948, State Department (SD), 758.00/6-2148, National Archives (NA), copy in Vol. 13, Neutrality Policy Commission's Archive (NPCA), Stockholm. Matthews reported discussions with Farquhar. This evidence is in line with Karl Molin's argument that the SDU proposal was mainly a domestic ploy by Erlander and Undén to remove foreign policy issues from the election agenda and not a sincere attempt to create a Scandinavian defence system. Molin, Omstridd neutralitet.

${ }^{3}$ Ibid.

${ }^{4}$ Wuori to Enckell, 17.7.1948. 
in July 1947, US-Swedish relations were still satisfactory. ${ }^{1}$ But the fact that the State Department sent a man of Matthews' calibre and views to Sweden did not bode well as to the ultimate aims of US policy. By early 1948, Matthews's campaign against Swedish neutrality was in full swing. ${ }^{2}$ In March 1948 he explained to the Swedish Foreign Ministry, how in case of Sweden remaining neutral in a future war 'our own duty of selfpreservation, and our responsibilities to the free nations of the West, would require us to prevent [the] output [of Swedish industry] from reaching the Soviet by action from the air, however much we would regret it' ${ }^{3}$ In April Hugh Cumming, counsellor in the US embassy, elaborated this further to an astonished audience of Swedish businessmen:

The Russians would probably not attack Sweden - they would leave Sweden to be neutral and buy from Sweden ball bearings, electrical machinery and such other materials or manufactures as they required. If the Swedes denied these materials to them that would be what the U.S. wanted of Sweden. If the Swedes did not, the U.S. would take steps to bomb Swedish industries out of existence in order to see that none of their products could reach Russia, neutrality or no neutrality. ${ }^{4}$

On leaving the 'party', Cumming told Henderson, his opposite number in the British embassy that he hoped he did not sound 'too tough', but 'I have instructions to speak in that way personally and unofficially and even to write it in private letters' 5

On the face of it, official US policy still was that it was up to Sweden itself to freely decide what its response would be to increasing East-West tension. Matthews, however,

\footnotetext{
${ }^{1}$ Lundestad, America, Scandinavia, and the Cold War, 102. Matthews served as director of the Office of European Affairs from 1945-1947 and was according to Lundestad well acquainted with the highest levels of policy-making in Washington.

${ }^{2}$ A telegram outlining the 'basic fallacies of Swedish thinking' from February 1948 is a landmark of the changed American policy. Matthews to Marshall, 6.2.1948, FRUS 1948 Vol. III, $23-24$.

${ }^{3}$ Matthews telegram to Marshall, 18.3.1948, SD, 758.00/3-1848, NA, copy in Vol. 13, NPCA.

${ }^{4}$ Henderson to Hankey, 21.4.1948, FO 371/71724.

${ }^{5}$ Ibid.
} 
exerted a strong influence in Washington to adopt a tougher line with Sweden. He successfully advocated a policy of rebuffing feelers from Sweden on informal staff discussions, stalling export licences for military technology to Sweden, to remove Swedish ports from US naval units' visit schedules to Scandinavia and to reiterate the fact that unless Sweden abandoned neutrality, no last minute help would be forthcoming from the US in an emergency. ${ }^{1}$ In the summer of 1948 , the consenus in both the State Department and in the Stockholm embassy was that 'the cure for isolation was isolation' . With the backing of the State Department in Washington, Matthews made the US attitude clear to Undén and the Swedish officialdom as a whole. ${ }^{3}$

With both the US and the Swedes having their horns locked like this, the British were faced with a difficult challenge. The US campaign, eagerly pursued by Matthews in Stockholm, increasingly distanced them from Bevin's stance that favoured patient persuasion instead of openly challenging the Swedes. The British found themselves in an uncomfortable mediating position, while Swedish and American views seemed to gain more distance from each other as time went by. Paradoxically enough, the more the Americans became involved in Scandinavia, the less there seemed to be chances to fulfill the original British intention of keeping the region together in the cold war. From the viewpoint of the variety of British interests in Scandinavia, this seemed a worrying prospect indeed.

Understanding American anxieties perhaps better than many of his colleagues in

\footnotetext{
' Matthews telegram to Marshall, 8.4.1948, SD, 758.00/4-848, NA, copy in Vol. 13, NPCA; Matthews telegram to Marshall, 21.4.1948, SD, 758.00/4-2148, NA, copy in Vol. 13, NPCA; Lovett telegram to Matthews, 15.4.1948, SD, 758.00/4-848, NA, copy in Vol. 13, NPCA; Llewellyn E. Thompson to Matthews, 24.7.1948, R 484 Stockholm Embassy, 43-49, Box 2, NA, copy in Vol. 19, NPCA.

${ }^{2}$ Matthews telegram to Marshall, 1.6.1948, SD, 758.00/6-148, NA, copy in Vol. 13, NPCA; SD memorandum for the President, 'Swedish Neutrality Policy', 3.6.1948, copy in Vol. 13, NPCA.

${ }^{3}$ Matthews to Marshall, 4.6.1948, SD, 758.00/6-348, NA, copy in Vol. 13, NPCA.
} 
London, Henderson wrote that there always was the chance that the US policy was in the end the right line with the Swedes, but it was 'the line of a strong nation. We are not considered to be a strong nation at present, even if we are potentially so, but we are considered, partly for that reason, to be more reasonable, more moderate and more sympathetic than the Americans. '1 Furthermore, the Swedes were 'afraid of America and respect her strength'. But they were not 'afraid of us'. ${ }^{2}$ The problem was to find a way that would combine the American toughness with the British soft approach, without contradicting each other and cancelling the effects of both policies out. The worst situation, of which the British had already some indication, was if the Swedes' 'Nordic quality of obstinacy' would turn them back into their shell and take an extremely defensive posture towards the West. ${ }^{3}$ Sverker Ȧström's, a junior but already influential official in the Swedish Foreign Ministry, views witnessed what this could mean, when he told Henderson that Sweden would if needed defend its neutrality against any aggression. Henderson asked him 'whether she would defend it against the Western Powers should [they] infringe it in any way and he said certainly they would'. When Henderson pointed out that that would put Sweden on the side of the Soviet Union, Àström said: 'Yes, that would be horrible'. ${ }^{4}$

From May onwards the FO searched for a solution that would bridge the gap between the US and Swedish positions, but the most urgent need was to persuade the Americans to give up their campaign. At the same time, the whole question of the US security guarantee was still under discussion in Washington, which did not give much room to the British either to demonstrate their anxiety to the Americans who were about to make a historic decision, or to side with them in order not to alienate the Swedes completely.

\footnotetext{
${ }^{1}$ Henderson to Hankey, 21.4.1948, FO 371/71724.

${ }^{2}$ Ibid.

${ }^{3}$ Hankey's phrase in a minute, 30.11.1948, FO $371 / 71455$.

${ }^{4}$ Henderson to Hankey, 21.4.1948, FO 371/71724.
} 
Hankey, reflecting on the 'extraordinary line the Americans are taking' was already in May preoccupied by a possible compromise solution, and Bevin himself became increasingly apprehensive about the dangers an open rift with the US might involve. ${ }^{1}$ In August, however, Bevin reaffirmed his previous policy so as to clear up any possible misunderstanding on that account. In the meantime, Swedish papers identified the British with the US 'war of nerves' against Sweden. ${ }^{2}$

Following Bevin's instructions, the British tried from June 1948 onwards to influence the Americans to lay off putting pressure or criticism on Sweden in discussions in Washington, London and Stockholm. ${ }^{3}$ The only chance of success lay in that the Americans were also acutely aware of the need to coordinate policies with the British, if any real leverage was to be created upon the Swedes. ${ }^{4}$ These attempts had barely started when the news that the British were selling more aircraft, including modern jet engines and airframes to Sweden, stirred up the Americans. ${ }^{5}$ Instead of becoming more responsive to the line the British were advocating, Matthews saw the British just in search of quick profits. In addition to his more famous remark 'why the hell should we spend money to rearm Brussels Pact countries when they are selling jets to neutrals', he also lamented the detrimental effects of British policy: 'It seems to us that reasonably good chances of getting Sweden into western camp are being sacrificed by short run interest of British aircraft industry and British ignorance of Swedish psychology. ${ }^{6}$ The argument, that it was in Britain's own interest to have Sweden as strong as possible was

\footnotetext{
' Hankey minute, 10.5.1948, FO 371/71724; Bevin minute, 19.6.1948, FO 371/71725.

${ }^{2}$ Aftonbladet, 16.6.1948; Svenska Dagbladet, 17.6.1948.

${ }^{3}$ FO telegram No. 6885 to Sir Oliver Franks, 25.6.1948; Hankey minute, 8.7.1948, FO $371 / 71725$.

${ }^{4}$ Benjamin M. Hulley to Hickerson, 10.6.1948, SD, 857D.20/6-1048, NA, copy in Vol. 13, NPCA.

${ }^{5}$ Medhurst (Washington) to Air Ministry, 29.7.1948; 23.9.1948, AIR 8/1582.

6 The first remark is quoted in Petersen, 'Britain, Scandinavia, and the North Atlantic Treaty', ftn. 49. Matthews telegram to Marshall, 17.9.1948, SD, 848.248/9-1748, NA, copy in Vol. 19, NPCA.
} 
countered with the argument that it was 'much more to British advantage (and ours) to have a western allied Sweden than the relatively minor increase in Swedish military strength'. 'A cancellation of British Vampire contract would help more than anything else' in getting Sweden along the right lines, and if it was not cancelled, 'we may just as well forget any thought of winning Sweden from neutrality'. ${ }^{2}$

If the British were slightly more successful in London and in Washington in justifying their arms export policy, in Stockholm their arguments fell on deaf ears. 'Please stop him [Matthews] making so much trouble if you can!', Hankey instructed Farquhar, who nonetheless could do little. ${ }^{3}$ On the contrary, on 4 September the US government adopted the policy outlined in the National Security Council report NSC 28/1, of which the aim was:

To make perfectly clear to Sweden our dissatisfaction with its apparent failure to discriminate in its own mind and its future planning between the West and the Soviet Union; to influence Sweden to abandon this attitude of subjective neutrality and look toward eventual alignment with other Western Powers in such form as may be found collectively acceptable. ${ }^{4}$

In addition, Swedish requests for armaments should be considered 'only after those of countries which have given indication to cooperate' were met. ${ }^{5}$ Against this background, Bevin's conversations with Marshall on 4 October were only a slight consolation. Marshall then went as far as saying that a Scandinavian neutral bloc might be acceptable, if certain Western mimimum requirements were fulfilled. As a military man, he

\footnotetext{
${ }^{1}$ Matthews telegram to Marshall, 10.9.1948, SD, 858.248/9-1048, NA, copy in Vol.19, NPCA.

${ }^{2}$ Matthews telegram to Marshall, 17.9.1948, SD, 848.248/9-1748, NA, copy in Vol. 19, NPCA.

${ }^{3}$ Hankey to Farqhuar, 4.10.1948, FO 371/71716.

${ }^{4}$ National Security Council report, 'The Position of the United States with Respect to Scandinavia', 3.9.1948, NSC 28/1, FRUS 1948, Vol. III, 232 - 234.

${ }^{5}$ Ibid.
} 
appreciated the British strategic anxieties and saw that 'the critical point was the strait between Denmark and Sweden. If that could be made impassable in time of war then a Scandinavian neutral bloc might not be too bad although we had a strong interest in the Norwegian coast-line and of course in Greenland'. ${ }^{1}$ This show of sympathy for British and Swedish viewpoints was, however, not followed by action, as no instructions to change the recently reaffirmed US policy were given. Despite Marshall's less hawkish personal attititude and wish to 'lay off such outspoken pressure tactics' as had been adopted by Matthews, both the State Department and Stockholm embassy continued along familiar lines, now fortified with the authority of NSC $28 / 1 .^{2}$ In a conversation with Cumming in October, Henderson failed to impress him of the significance of both Bevin's and Marshall's viewpoints and no agreement was reached on how to proceed. ${ }^{3}$ Instead, the American Economic Cooperation Administration (ECA) mission to Sweden threatened to withdraw the agreed allocations of ERP aid 'unless some change (nature not indicated) was made in Swedish economic policy' ${ }^{4}$ This curious threat, which in the end was not carried out, was additional proof that it was not only Matthews's staff, but also other US agencies who joined in the attempts to put pressure on Sweden.

If Matthews's embassy continued to be unresponsive to British arguments, a more gratifying audience was found in Sweden. By autumn 1948 there was no longer any doubt in Sweden that the West was not united in the question, and if the Swedes had the nerve to maintain their line, no serious trouble was likely to ensue. In a conversation in October 1948 with the new Swedish ambassador in London, Gunnar Hägglöf, Hankey

\footnotetext{
${ }^{1}$ Record of conversation between Marshall and Bevin in Paris, 4.10.1948, FO 800/500; Petersen, 257.

${ }^{2}$ Petersen, Britain, the United States and Scandinavian Defence, 25.

${ }^{3}$ Henderson telegram No. 570 to FO, 13.10.1948, FO 371/71453; Cumming to Matthews, undated (October 1948), Vol. 19. NPCA.

${ }^{4}$ OEEC Paris delegation telegram No. 28 to FO, 27.10.1948, FO 371/71967; Henderson to Hankey, 21.10.1948, FO 371/71725.
} 
merely stated that the British were satisfied that the Scandinavian governments had decided to explore the possibilities for unified Scandinavian defence. ${ }^{1}$ Significantly, however, Hankey emphasised that the British, unlike the Americans, understood that Sweden had a unique position along the immediate frontline facing the Soviet Union. As the US was geographically further away, it had been psychologically understandable that they had difficulties in understanding the nuances of the situation in Western Europe when they pressed for a uniform response from all Europeans to the Soviet threat. The British were certain that they could advocate a more carefully balanced Western approach to Scandinavian questions in Washington, and with some 'common sense', there should be a way to find a solution to Scandinavia's relations with the Western bloc that took into consideration 'Sweden's special position and at the same time could satisfy Norwegians' security needs. ${ }^{2}$

Problems in the coordination of American and British policies and Sweden's obstinacy were nonetheless contrasted by advances in the main issue: US commitment in the defence of Western Europe. The results of the so-called Pentagon talks between 22 March and 1 April between the US, the United Kingdom and Canada had already been promising from the British point of view. The US was then warming to the idea of an Atlantic defence system, and a major breakthrough took finally place in June 1948, when the State Department came round to the idea of supporting a formal commitment with the European allies. ${ }^{3}$ This was followed by President Harry S. Truman's announcement on 2 July, that the Americans were willing to resume negotiations with Western Europe about security issues. Truman specifically mentioned Norway and Denmark annong the

\footnotetext{
' Hägglöf to Erlander, 12.10.1948, Hp $1 \mathrm{Ba}$, vol. 93.

${ }^{2}$ Ibid.

${ }^{3}$ Wilfried Loth, 'The Formation of the Blocs: Structures of the East-West Conflict, 1948-50', Norbert Wiggershaus \& Roland C. Foerster (eds.), Western Security Community, 1948-1950. Common Problems and Conflicting National Interests during the Foundation Phase of the North Atlantic Alliance. (Oxford: Berg, 1993), 11 - 12.
} 
countries concerned, but was more reserved about Sweden and Portugal. ${ }^{1}$ It was, however, unlikely that the process would lead to anything definite before the US presidential elections in November. In the Washington Exploratory Talks that began in the summer 1948 and continued until March 1949, the Americans at first stressed the importance of the 'stepping stone' concept, which placed Greenland, Iceland and Norway in a central position in North Atlantic strategy. ${ }^{2}$ From this they gradually moved closer to the British position that favoured full membership in an Atlantic pact for all countries who were willing to join. But which would these countries be?

\section{A British compromise proposal}

The Swedish proposal for a neutral Scandinavian defence pact has been interpreted as a competitive proposal to a possible inclusion of Norway and Denmark into an Atlantic security system. ${ }^{3}$ But as seen from London, and especially from the COS point of view, the plan had its own merits as well. In British eyes, the question was how to find a way that Sweden also could be connected to an Atlantic security system. Of course, to have all the Scandinavian countries in the Atlantic Pact would have been the most favoured option. As this proved to be unlikely during 1948, a unified Scandinavian defence system was the only realistic solution to the problem of Scandinavian defence, as long as nonalignment or neutrality could be interpreted flexibly enough to allow for preparations for common action in certain contingencies.

During their discussions in early October, Bevin and Marshall agreed that 'for the present no approach should be made to Norway and Denmark in view of the prospect

'Petersen, 'Britain, Scandinavia and the North Atlantic Treaty 1948-49', 255.

${ }^{2}$ Ibid., 258 - 259.

${ }^{3}$ Aalders, Swedish Neutrality and the Cold War, 154 - 155. 
that these countries might be able to agree with Sweden on a Scandinavian defence pact' ${ }^{1}$ An invitation to Norway and Denmark to join the discussions about the Atlantic Pact would probably have led the already difficult Scandinavian talks into a complete deadlock. Neither Bevin nor Marshall wished to prejudice the negotiations with their own actions, and take the blame for their failure. The Scandinavian governments had set up a committee to explore on a practical level the possibilities of a Scandinavian defence pact, and the British made clear to the Swedes that they wanted to wait for the results of their work before making any official approaches concerning Scandinavia's participation in the wider defence arrangement. ${ }^{2}$ Bevin was still, as before, willing to follow a 'wait and see' policy concerning Scandinavia.

Officials in Whitehall nevertheless kept the issue alive. Already in May 1948, Sargent had suggested that 'in the end it may pay us to work for a firm attachment of Norway and Denmark to the Western Atlantic Powers and for Sweden to be indirectly attached through a Scandinavian Union to Norway and Denmark. This might avoid the Swedes being dragged in automatically unless Norway or Denmark were attacked though we should expect her in any case to adopt an attitude of favourable non-belligerency rather than complete neutrality'. ${ }^{3}$

In September-October 1948, Hankey put forward a compromise proposal in the FO. ${ }^{4}$ The consensus on the official level by then was that there was little hope of having

\footnotetext{
${ }^{1}$ Defence Committee minutes, 7.10.1948, CAB 131/5.

${ }^{2}$ Hägglöf to Beck-Friis (Stockholm), 26.10.1948, Hp $1 \mathrm{Ba}$, vol. 93.

${ }^{3}$ Quoted in Turner, Britain, the United States and Scandinavian security problems 1945-49, 264.

${ }^{4}$ Hankey memorandum, 'The Relation of Sweden to Scandinavian Co-operation and to North Atlantic Security', 5.10.1948, FO 371/71458. This so-called 'Hankey Plan' was probably first dealt with in scholarly literature by Knut E. Eriksen in 'Nato, Norden og "den utro tjener" Halvard Lange', Internasjonal Politikk, Vol. 35, No. 2 (1977), 261 - 302. Other detailed accounts are found in Petersen, Britain, the United States and Scandinavian Defence, 31 - 37; Eriksen \& Skodvin, 'Storbritannia, NATO og et skandinavisk forbund', 489 - 492; Turner, Britain, the United States and Scandinavian security problems 1945-9, 263 - 284.
} 
Sweden join the Atlantic security pact on equal terms with other powers. The first aim then was to draw Norway and Denmark into an Atlantic Pact and that they should thereafter try to attach Sweden to Norway and Denmark. According to Hankey's solution, this could be achieved in a system of 'interlocking security pacts', combining the need for Scandinavian unity with ties to the West.

While Norway and Denmark might come in as full members of the Atlantic alliance, they could also have membership in a Scandinavian defence system with Sweden. At the same time, if necessary, they could have a more limited commitment of mutual assistance in the Atlantic alliance than other powers, basically limiting their active role to their own region. Sweden's obligations would have been to remain non-belligerent, not neutral, 'in any war in which Denmark and Norway are engaged [through their membership in NATO] but are not actively attacked'. ${ }^{1}$ During such time Sweden would defend her territory against any Soviet attempts to violate it, as required also from a neutral, but would also participate, 'so far as she could', in economic warfare against the Soviet Union. Sweden would also cooperate with Denmark and Norway by giving radar information of any impending attack on them.

In the event of a Soviet attack on Denmark or Norway, Sweden would 'enter the war with all her forces and co-operate in the defence of Scandinavia as a whole in accordance with plans to be arranged in advance in inter-Scandinavian defence talks'. ${ }^{2}$ Only in this case, i.e., when Scandinavia would have been attacked, would Sweden be helped by Great Britain, the US or other Western powers. In return, Sweden would be entitled to assistance from Norway and Denmark if attacked. And then the crucial part of the deal: 'This would involve the other members of the N. Atlantic Security Pact, but is is unlikely that Russia would attack Sweden except as part of or as a prelude to a general attack on

${ }^{1}$ Ibid.

Ibid. 
the west. ${ }^{1}$ In other words, the West would help Sweden as it could, because it would be in a war in any case against the Soviet Union by then.

Hankey thought that his plan contained the ingredients for a successful compromise. In his view:

Such a system would recognise the urge of the Swedish people towards neutrality, or non-belligerency, as well as the desire of all Scandinavians for Scandinavian co-operation. It would allow the nature of the attachment of the Scandinavian Powers to the Atlantic Security Pact to shade gradually off eastwards as it were and would be less likely to provoke Russia to annex or communize Finland than a direct alliance between Sweden and the Western Powers. It would give the Danes and Norwegians all they really need from Sweden, viz. assurance of effective support according to prearranged plans if they are actually attacked. It would warn the Russians that they could not safely attack Sweden in isolation (though they would be most unlikely to believe that they could). By making the Swedes feel that they were backing on to something fairly solid, viz, Norway and Denmark with the full support of the members of the N. Atlantic Security Pact, it would give the Swedes confidence, while they would only be expected to intervene if their own chance of national safety or survival were most gravely compromised by the threat of Soviet encirclement. ${ }^{2}$

The COS thought the solution proposed by Hankey 'an ingenious way of bringing Sweden into the camp of the Western Allies'. ${ }^{3}$ There were two points, however, to be considered. The first was of the possibility of armed assistance from Britain. 'As you know, it has always been the opinion of the Chiefs of Staff that they cannot contemplate direct assistance by sending British forces to Scandinavia. The most that could be hoped would be that action elsewhere, and possibly some small degree of air and naval assistance, might afford indirect help to the Scandinavian countries. ${ }^{4}$ The second point concerned the situation of materiel in Norway and Denmark, in case that the plan did not

\footnotetext{
${ }^{1}$ Ibid.

${ }^{2}$ Ibid.

${ }^{3}$ Lt. Col. Waterfield (MoD) to Hankey, 15.9.1948, FO 371/71458.

${ }^{4}$ Ibid.
} 
come off. 'If Sweden does not come in, the effect will be to turn both Norway and Denmark to us for the supply of equipment which they are now getting and should continue to get from Sweden'. ${ }^{1}$ Both these points highlighted the reluctance of the COS to consider Norway and Denmark as members in an alliance where Britain would inevitably, at least in the beginning, bear the main burdens of assistance both in peace and war. Hence, a solution along the lines of the 'Hankey plan', as it was soon jocularly dubbed by Collier, was strongly supported by the COS. ${ }^{2}$

The Americans gave their views on the plan in November. These were on the 'working level', probably meaning that it had not been discussed with Marshall or outside the State Department. ${ }^{3}$ They agreed with the basic idea behind the paper and in particular with the view that 'every effort should be made to induce Norway and Denmark to become full parties to a North Atlantic Security Treaty. If these two countries do become parties, the problem of Sweden might well be solved if that country were prepared to enter into a satisfactory Scandinavian Defence Treaty'. ${ }^{4}$ But Hankey's suggestion of Western support to Sweden through their commitment to Norway and Denmark came too close 'to a one-way guarantee of Sweden by the parties of the North Atlantic Treaty and it would be unfortunate if any such suggestion were made to the Swedes. If the Norwegians and Danes heard of it they might well also hope to obtain a similar one-way guarantee'. The Americans preferred an interpretation that 'an armed attack on Sweden, assuming it were not a party [to NATO], would merely require consultation'. Otherwise the proposed SDU, if it could be in this way linked to the West, was a desirable objective. In Hickerson's view:

\footnotetext{
1 Ibid.

${ }^{2}$ Hankey to Collier, 25.1.1949, FO 371/77392. In this letter Hankey asked Collier to stop referring to his proposal as the 'Hankey plan', as the 'joke wasn't appreciated overmuch in high quarters'. Ibid.

${ }^{3}$ Lundestad, America, Scandinavia, and the Cold War, 283.

${ }^{4}$ Hickerson to Hoyer Millar, 15.11.1948, FO 371/71454.
} 
If such an interlocking arrangement materialized the situation would be as follows: An attack on Belgium would require full assistance from Norway and Denmark but not from Sweden. An attack on Norway or Denmark would require assistance from all parties to the Atlantic Treaty and from Sweden. An attack on Sweden would require assistance from Norway and Denmark but not from the other parties to the Atlantic Treaty unless, as a result of consultation, they chose to give it. No one-way guarantee would be given. ${ }^{1}$

Hankey's comment to this was that 'of course if Sweden only gets consultation, she will take no risks at all on our behalf. I don't therefore think this will be realisable in practice' ${ }^{2}$ Otherwise it was encouraging that Hickerson was in principle in favour of such a special arrangement. ${ }^{3}$ The FO nevertheless accepted that the idea of one-way guarantee to Sweden should be dropped, as the whole scheme needed to be sold to the Norwegians before anything more could be done. ${ }^{4}$

The chances of achieving this proved to be more difficult than was anticipated. In the end, the whole scheme was shelved principally because of Norwegian opposition. The Norwegian ambassador in London, Per Preben Prebensen was initially enthusiastic about it, but Lange, after discussions with the Prime Minister Einar Gerhardsen, rejected the idea. On 20 October Prebensen said he had had a personal telegram from Lange saying that the idea was liable to raise internal difficulties in the Norwegian Cabinet and he urgently hoped nothing of the sort would be said to the Swedes 'who might be less inclined to make their proper contribution'. ${ }^{5}$ In Norwegian eyes, the Swedes might think that they 'could get something for nothing' ${ }^{6}$

It was politically hard to accept in Norway, that Sweden would gain in security by

\footnotetext{
'Ibid; Lovett to Matthews, 17.11.1948, FRUS 1948, Vol. III, 272 - 273.

${ }^{2}$ Hankey's note in the margin of Hickerson to Hoyer Millar, 15.11.1948, FO 371/71454.

${ }^{3}$ Hankey minute, 6.12.1948, FO 371/71454.

${ }^{4}$ FO telegram No. 13033 to Washington (Kirkpatrick to Hoyer Millar), 9.12.1948, FO $371 / 71454$.

${ }^{5}$ Kirkpatrick to Hoyer Millar, 23.10.1948, FO 371/71454.

${ }^{6}$ Lundestad, America, Scandinavia, and the Cold War, 283.
} 
contributing less than others. The Norwegians were not at all keen to give Sweden this kind of preferential treatment, which would provide Sweden with military assistance in a conflict without a firm commitment to the Atlantic Pact as a whole. ${ }^{1}$ The Norwegian political leadership rejected the plan, even if it made sense in strategic terms, since Sweden was the only source of immediate help if Norway was attacked. Evidently, the political price was too high for the Norwegian political leadership. To accept Hankey's proposal would have meant that an obstinate policy of neutrality had paid bigger dividends than deciding for closer association with the Western cause.

But another stumbling bloc would have undoubtedly been, had the plan gone further than this, the Swedish government itself. Undén showed no signs at this point that there existed conditions for a third way between strict neutrality and open alignment with the West. During discussions with the Norwegians and the Danes, the Swedes had shown little interest in accepting steps that required even less modification to their existing policy than the 'Hankey plan' would have done. ${ }^{2}$ It has been a recently debated topic in Sweden whether Undén in the end upheld his policy of neutrality as consistently as has been believed. ${ }^{3}$ Bengt Nilson in particular has put forward an argument that Undén tried to find a 'third way' between isolated neutrality and open Western alignment. Nonetheless, leaving aside the years 1950-52 for the moment, the balance for 1948 seems to be against Bengt Nilson's 'third way' argument. ${ }^{4}$ Due to Undén's obstinate position, of which his diary bears witness, there was in the autumn of 1948 virtually no chance of the British plan succeeding, even had the Norwegians supported it. ${ }^{5}$ The prognosis for

\footnotetext{
'Petersen, 'Britain, Scandinavia and the North Atlantic Treaty', 261; Lundestad, America, Scandinavia, and the Cold War, 282 - 283.

${ }^{2}$ Lundestad, America, Scandinavia, and the Cold War, 283.

${ }^{3}$ Bengt Nilson, 'Undéns tredje väg: Sverige i det kalla kriget, 1950-1952'; idem., 'Undéns tredje väg under det kalla kriget. Sverige kryssade framgångsrikt mellan blindskären', $S v D$, 9.5.1994.

${ }^{4}$ See Alf W. Johansson, 'Undén var bitter över pätryckningar', $S v D, 20.5 .1994$.

${ }^{5}$ Undén's diary, 30.10.1948, Kungliga Biblioteket (KB), Stockholm.
} 
a successful completion of the SDU were not too good either. All depended on the outcome of the results of the Scandinavian defence committee and the ensuing interScandinavian political talks on the one hand, and on the discussions taking place between the Western powers about the ultimate character of the projected Atlantic alliance on the other.

The way to the Atlantic Treaty

Even if the British were willing to give the Scandinavians the time they needed to make up their minds about the best future framework for their security, the process leading to the North Atlantic Treaty accelerated in November, after the presidential elections in the US. Both Sargent and Hankey warned the Swedish ambassador in London about this, but continued to emphasise that they wanted to hear the results of the Scandinavian defence committee before a final decision about Scandinavia's role in the Atlantic pact was made. They still conveyed strong support for developing Scandinavian defence cooperation. ${ }^{1}$ The Swedish ambassador pointed out that their government was in complete agreement with the British on this point. That was about as far as their agreement went. Hankey qualified the British attitude by saying, that in their view, a Scandinavian defence pact could not provide adequate security without Western assistance. The emerging Atlantic pact would be 'a unique concentration of power in history' and the British hoped the Swedes would not completely neglect this. ${ }^{2}$

In November 1948, Bevin began to finalise his own suggested list of participants in the Atlantic pact. Bevin wanted to sound out Eire, Iceland, Portugal, Denmark, Norway,

\footnotetext{
${ }^{1}$ Hägglöf to Undén, 6.11.1948, Hp $1 \mathrm{Ba}$, Vol. 94.

${ }^{2}$ Ibid.
} 
and still, 'if possible, Sweden' as to their readiness to accept an invitation to a conference for the framing of the treaty. ${ }^{1}$ Bevin himself raised doubts about inviting Italy, and in Cabinet discussion, Portugal's inclusion was also questioned. Interestingly enough, although it is not known who made the suggestion, Finland was also to be invited in the conference. Bevin quickly rebuffed the idea, as he was 'strongly opposed to giving any security guarantees which it would be impossible to fulfil in practice'.2

While Bevin still included all the Scandinavian countries in his list of possible members of the Atlantic pact, the French were more sceptical. As the French ambassador in London, René Massigli, put it to his Swedish colleague, in the recent discussions in the Consultative Council set up under the Brussels Treaty, the Scandinavian countries were mentioned only in passing. ${ }^{3}$ There was also more general scepticism in Britain about entering into military commitments in Scandinavia, as the editor of the Times, W. F. Casey explained to Hägglöf. ${ }^{4}$ More important than this scepticism was the fact that there was also a stronger tendency in the US to include only those Scandinavians that had fewer inhibitions than the Swedes, in an Atlantic pact. ${ }^{5}$ The pull from the US proved to be the decisive factor.

Towards the end of 1948, the increasing political drive from the US favouring Norway's and Denmark's participation and Sweden's refusal to move from its positions, slowly made it increasingly unlikely that there would be enough political will on either side to bridge the gap. While Bevin strongly opposed the idea that Britain was 'forced into any exclusive association with France and the Benelux countries', which of course had already taken place in March 1948, he was not willing to let any country slow the

\footnotetext{
${ }^{1}$ Cabinet minutes, 4.11.1948, CM(48)68, CAB 128/13.

${ }^{2}$ Ibid.

${ }^{3}$ Hägglöf to Dahlman (Stockholm), 2.11.1948, Hp $1 \mathrm{Ba}$, vol 94.

${ }^{4}$ Hägglöf to Dahlman, 19.11.1948, Hp $1 \mathrm{Ba}$, vol. 94.

${ }^{5}$ Hickerson note (to the British embassy in Washington), 9.12.1948, FO 371/71455.
} 
process leading to the Atlantic Pact. The widening of the Brussels Treaty to an Atlantic system was imperative, and by this stage he named particularly Italy and the Scandinavian countries as possible members. ${ }^{1}$

In November 1948 the US finally brought things to a head with the Swedes. While the deliberations of the Scandinavian defence committee on the strategic aspects of common Scandinavian defence were still in progress, Matthews, acting under instructions from Washington, told the Swedish government that a Scandinavian pact based on neutrality, or a neutral Sweden, could not expect material assistance from the US. ${ }^{2}$ Matthews' demarché in Stockholm was followed by a more mollifying approach by the British, who emphasised that the Swedes should not interpret this as political pressure, but merely reflecting difficulties in the availability of military supplies. ${ }^{3}$ This did not convince Undén at all, who lamented the methods of US diplomacy. ${ }^{4}$ At the same time, a decision was made in December by Bevin and Marshall that invitations to join the discussions leading to an Atlantic pact should be sent to Norway and Denmark, leaving Sweden out. This did not lead Hankey to give up his plans to have Sweden included. He wrote on 14 December: 'What is aggravating is that the Swedes are getting more and more left out, whereas we want them in, in some form or other. The defence of Scandinavia makes no sense without Sweden, and Norway and Denmark will be a real burden to us'. 5 The FO officials thus continued their support for the SDU, which had, in some form or another, to be linked to the Atlantic pact. This was by now also made clear to Undén in Stockholm and to Hägglöf in London, although no explicit references

${ }^{1}$ Cabinet minutes, 6.12.1948, CM(48)78, CAB 128/13.

${ }^{2}$ Lovett to Matthews, 22.11.1948, FRUS 1948, Vol. III, 281 - 282; Matthews to Marshall, 26.11.1948, FRUS 1948, Vol. III, 295 - 296; Farquhar telegram No. 655 to FO, 16.12.1948, FO $371 / 71455$.

${ }^{3}$ Undén memorandum, 18.12.1948, Hp $1 \mathrm{Ba}$, vol 94.

${ }^{4}$ Undén's diary, 29.11.1948.

${ }^{5}$ Hankey minute, 14.12.1948, FO 371/71455. Turner, Britain, the United States and Scandinavian security problems 1945-49, 284. 
were made to the 'Hankey plan'.'

The COS also doubted the sensibility of just including Norway and Denmark in the Atlantic Pact. The situation regarding Sweden made them increasingly worried about the possible overextension of British resources in northern Europe. Their scepticism was known to the Swedes, and in no way encouraged them to reconsider their position. ${ }^{2}$ In early January 1949 the COS agreed that as the defence of Scandinavia had to be considered as one problem, 'it was not sound from the military point of view to include Norway and Denmark but omit Sweden'. ${ }^{3}$ The COS went as far as to advise the FO to accept 'a separate neutral bloc of all three Scandinavian countries if there was no chance of getting all three into the North Atlantic Pact'. This departure from the previous line that had supported the 'Hankey plan' of interlocking security pacts, was a remarkable display of their view that 'from a military point of view the most important thing was that the three Scandinavian countries should stand together'. ${ }^{4}$ The COS did not want Norway and Denmark as net liabilities in the Atlantic Pact. Their views were met with some sympathy in the FO, but a way out of the current impasse was hardly in sight. Commenting upon Hankey's scruples about dividing Scandinavia and reflecting on the art of making the most of what was on offer, Kirkpatrick minuted on 22 December 1948: 'We shall lose the whole Atlantic Pact if we go in for perfection'.5

In January the political difficulties in creating the SDU finally became insurmountable, due to the fundamental differences between the Swedish and Norwegian governments. The Swedish demand for a neutral pact could not be reconciled with the Norwegians' requirement for an Atlantic link. This did not surprise the FO. But if the

\footnotetext{
${ }^{1}$ Undén memorandum, 18.12.1948, Hp $1 \mathrm{Ba}$, vol 94.

${ }^{2}$ Conversation between Hägglöf and Wuori. Wuori to Enckell, 1.3.1949.

${ }^{3}$ COS minutes, 3.1.1949, COS(49)1, DEFE 4/19.

${ }^{4}$ Ibid.

${ }^{5}$ Kirkpatrick minute 22.12.1948, FO 371/77391.
} 
Swedes remained determined to stick with their neutrality, Hankey was just as determined. His persistence in trying to find a compromise formula between an Atlantic Pact and a neutral Scandinavian defence pact can be explained by the pressure from the COS on the crucial importance of a Swedish contribution to the defence of Scandinavia. COS pressure also explains why the FO was so reluctant to go along with the American preference for Norway and Denmark in the Atlantic Pact, leaving Sweden isolated. ${ }^{1}$

Hankey was also encouraged by the approach of some senior Swedish military officers, who urged the British to use their influence to have Sweden included in the Atlantic Pact. ${ }^{2}$ The prospects of being left outside the Pact had alarmed the Swedish military leadership, who thought that their own government was making a serious mistake. ${ }^{3}$ The Swedish officers said that they were pulling all possible strings within and outside the Swedish government to make it to change its mind. Hankey saw, that it was now or never to launch the last attempt to reach a sensible solution for Scandinavian defence. The conclusions of the Scandinavian defence committee also reinforced the view that the SDU would have to rely on some kind of assistance from the West to be effective. $^{4}$

In the end, Hankey's last attempt to link Sweden with the West through military pledges with its neighbours was no more successful than his original proposal of autumn 1948. ${ }^{5}$ Despite the fact that many of the FO officials dealing with the question and the COS were inclined to prefer closer Scandinavian military cooperation over partial NATO membership, the FO formally rejected the idea of a neutral Scandinavian pact on 19

${ }^{1}$ Turner, Britain, the United States and Scandinavian security problems 1945-49, 328.

${ }^{2}$ Skodvin, Nordic or North Atlantic Alliance?, 73 - 74.

${ }^{3}$ Hankey memorandum, 30.12.1948, FO 371/77400.

${ }^{4}$ Scandinavian defence committee's report 1949, Försvarsdepartement, vol. F I: 181 B, RA.

${ }^{5}$ On the second, diluted version of the original plan, Turner, Britain, the United States and Scandinavian Security Problems 1945-49, 283 - 285. This version would have left Norway and Denmark outside the Atlantic pact, with separate security arrangements with Britain and the US. 
January 1949. On 23 January Bevin finally and decisively shelved Hankey's compromise formula. ${ }^{1}$ With so much at stake in the scheme as a whole, Britain could not risk an open dispute with the Americans over the composition of the alliance. Bevin's views towards Swedish neutrality had also, possibly influenced by the US line, firmed up, as he explained to the Swedish ambassador in early February that in his view the planned neutral Scandinavian defence pact 'did not meet the requirements of the moment' and that neutrality in principle was not an adequate response in the current world situation. ${ }^{2}$

During the final months of the negotiations leading to the North Atlantic Treaty, it became clearer than ever that Britain had to accommodate its own aims with American policy towards Scandinavia. This tendency was the strongest in the FO, where the imperative need of involving the Americans firmly in Europe brushed other considerations aside. Thus, confronted by the US desire to have Norway and Denmark in the North Atlantic Treaty, which Bevin had himself instigated in March 1948, a solution that would have saved Scandinavian unity had to be abandoned. It is clear from Undén's diary that he was very well aware of the differences in the basic attitudes between the Western powers and the 'more understanding' British line, but was disappointed by Britain's inability to use its influence more effectively in Washington. ${ }^{3}$ Nevertheless, after Norwegian and Danish participation in the Atlantic pact was secured, there was less tension in the air about Sweden's neutrality policy.

\footnotetext{
1 Petersen, Britain, the United States and Scandinavian Defence 1945-1949, 40 - 41.

${ }^{2}$ Hägglöf to Utrikesdepartement, 3.2.1949, Hp $1 \mathrm{Ba}$, vol 95.

${ }^{3}$ Undén's diary, 19.1.1948. An example of an earlier interpretation, that sees Britain, not the US, as the main instigator of the strategic split in Scandinavia and responsible for the failure of the SDU is Möller, Östen Undén, 317 - 351. This is mostly based on Undén's remarks from as late as June 1949, when he wrote in his diary: 'Reports confirm that it was England who insisted on Norway's adherence to the A-pact, not the USA. The motive [was] England's strategic interest'. Ibid., 350; reported in Wuori to Enckell, 5.5.1949. That this was not the case is clear, but neither were Undén's remarks from June 1949 particularly representative of 'Swedish perceptions', as has been argued in Salmon, 'Great Britain and Northern Europe', 207. If the notes Undén wrote afterwards are set against his earlier observations of British policy, they merely show the extent of his disappointment.
} 
If hard, military-political security structures could not be extended to cover all of Scandinavia, other ties that would bind Sweden firmly to the West had to be found. In 1949, these were more easily achieved elsewhere than in the realm of military commitments. Where a diplomacy of military security failed, economic diplomacy was needed. But as previously, the economic sphere provided not only opportunities for closer cooperation, but also potential pitfalls. 
STRENGTHENING THE OEEC LINK: UNISCAN, 1949-54.

Despite the fact that Scandinavia was strategically divided by 1949, participation of Sweden in the ERP was considered an important step towards what Bevin believed to be an 'organic' way of consolidating Western Europe. Despite pulling Sweden into the process of Western cooperation at the level of practical and technical economic cooperation that began in the OEEC in Paris, the public agenda had been dominated by more dramatic questions of military security and here Sweden's neutrality policy had given rise to most difficulties. However, after the signature of the Atlantic Pact in April 1949 , the security dimension receded to the background, and was mostly confided to confidential talks between service authorities. While the search for practical solutions to Scandinavia's defence problems continued, other developments leading to a higher degree of coordination and cooperation took place on the economic sphere. This meant continuing and also deepening cooperation in the OEEC, but from January 1950 onwards there was also a specifically Anglo-Scandinavian economic forum, Uniscan. ${ }^{1}$ At the same time, economic diplomacy proved to be as problematic a foreign policy tool as before, when trouble in Anglo-Swedish trade relations began to mount after the outbreak of the Korean war.

Uniscan's direct economic importance was limited to certain technical questions. ${ }^{2}$

${ }^{1}$ Other names given by journalists included Ukiscan, Uniskan, Scandanglia, Scanuk, Brisk (in Norway) or L'uniscan and Uniscam (in France). These names compared well with such contemporaries as Franebel, Finebel, Fritaluxal, Fraswitaluxal, Benefrit or Benefit. Cripps said that it was a 'scandangle' that such names should be allowed at all. Cripps' speech to the Treasury staff, 11.1.1950, Sir Stafford Cripps Papers, Nuffield College, Oxford. Cripps's own favourite would have been 'Skanuk', as it reminded him of 'a viking war cry'. Hägglöf, Fredens Vägar, 179.

${ }^{2}$ Previous authors have been unanimous of Uniscan's neglible economic impact, and largely dismissed it. William Diebold Jr., Trade and Payments in Western Europe. A Study in Economic Cooperation 1947-51 (New York: Harper \& Brothers, 1952), 143 - 144; Bo Stråth, Nordic Industry and Nordic Economic Cooperation. The Nordic Industrial Federations and the Nordic Customs Union Negotiations 1947-1959 (Stockholm: Almqvist \& Wiksell International, 1978), 87 - 92; Milward, The Reconstruction of Western Europe, 316 - 319; af Malmborg, Den 
Rather than becoming a regional economic bloc, it was not much more than a club of like-minded people, or an official discussion forum. It did not become the means for continuing Britain's hegemony in Scandinavia's foreign trade and could not forestall the long term effects of West German competition for Scandinavian markets and rawmaterials. But politically, and this was as originally intended, Uniscan was more successful in consolidating the Anglo-Swedish axis in questions of European economic cooperation, and ultimately, integration. Besides creating a forum for inter-Scandinavian cooperation, it also strengthened the OEEC link with Sweden. From the vantage point of the cold war, Uniscan's significance was in the way it provided an additional institutional link between neutral Sweden and the United Kingdom.

To a degree the existence of this link also compensated for the failure to establish any formal political or security structures with Sweden. By ties like those in the OEEC or Uniscan, the Council of Europe and later EFTA, neutral Sweden became a member of a wider group of Western nations, as defined by the cold war, and a closer partner of Britain in particular. That could not solve the political or defence problems of Sweden's official foreign policy, but provided a necessary way to keep a window open for Sweden and not to isolate it from the West. Again, as in the field of defence, Britain had its own, specific role as a cornerstone of the arrangement.

\section{The establishment of Uniscan}

The idea of re-establishing the prewar relationship between Scandinavia and the sterling area surfaced soon after the war. Nevertheless, before 1949 neither specific plans nor written documents were presented. Schemes for closer cooperation in the economic field

ständaktiga nationalstaten, $91-92$. 
between Britain and the three Scandinavian countries were first put forward at an official level in the Treasury in January 1949, after a suggestion from the Bank of England. ${ }^{1}$ Officials then played with an idea of some kind of Anglo-Scandinavian economic association, or of Scandinavian membership of the sterling area. But referring to the need to let the dust settle down after the SDU failure and the politico-strategic split in Scandinavia, Cripps said that it was wise to wait until 'all matters connected with the North Atlantic Pact had been cleared up before going ahead'. ${ }^{2}$ Also, the sterling crisis of the summer 1949 kept the officials busy and postponed any other initiatives until the devaluation of the pound in September $1949 .^{3}$

Later in autumn 1949, the time was ripe for further initiatives, and the question of Scandinavia's relationship to the sterling area and closer cooperation with Britain was brought up by Treasury in October. ${ }^{4}$ There were several reasons why economic aspects of Britain's policy towards Sweden and Scandinavia materialised in the autumn of 1949. First were the events in the OEEC in August-September. Then the French finally changed sides in the longstanding Anglo-American dispute over the character and ultimate goals of the organisation, and joined the Benelux-countries and Italy in exploring further economic cooperation outlined in the Finebel/Fritalux proposals. ${ }^{5}$ This meant that the British were left alone with the Scandinavians in opposing the increasingly influential and better consolidated Franco-American axis. This required more consultation between

\footnotetext{
${ }^{1}$ E. W. Playfair (Treasury) (T) to Rowe-Dutton (T), 13.1.1949, T 236/5370; Playfair to George Bolton (Bank of England), 17.1.1949; Lithiby minute, 21.1.1949, OV 28/31, Bank of England Archive, London. See also Playfair to Allan Christelow (UK Treasury delegation, Washington), 20.12.1949, FO 371/78139.

${ }^{2}$ Informal Note of a Meeting held in Commonwealth Relations Office, 9.12.1949, FO $371 / 78139$.

${ }^{3}$ Playfair minute 6.7.1949, T 236/5370.

${ }^{4}$ Playfair to A. P. Grafftey-Smith (Bank of England), 11.10.1949, T 236/5370.

${ }^{5}$ Gérard Bossuat, La France, l'aide américaine et la construction européenne 1944-1954, Vol. II (Paris, Comité pour l'historie économique et financière, Ministère des Finances, 1992), 707 - 712. See also Richard T. Griffiths \& Frances M. B. Lynch, The Fritalux/Finebel Negotiations 1949/1950 (Florence: European University Institute, 1984).
} 
the countries, and more coordination of policies in the OEEC. As Playfair put it in October: 'I am becoming increasingly of the view that we ought to develop our thoughts on closer relations with Scandinavia as the only means of avoiding being faced by a United Europe which we either have to keep out or get into.'

The second reason arose from the perceived need to achieve a wider degree of liberalisation in the unflexible current trading situation, especially in the field of payments. The bilateral, annual trade negotiations framework was politically troublesome and any steps towards increased flexibility were welcomed. It seemed that these could be first and most easily be taken on the financial and payments side. Also, as Sir Henry Wilson Smith from the Treasury said in December 1949, both the OEEC-wide liberalisation process and the European payments union scheme in the OEEC spoke for a special financial arrangement between Britain and the Scandinavian countries, which 'will make it somewhat easier for all of us to face what is bound to become an increasingly difficult process. I think we can help each other in acting in even closer consultation than in the past'. On the trade side, 'such a close relationship would lead to a sympathetic understanding of each other's position as distinct from the bilateral horse trading that we have pursued in the past' ${ }^{2}$

The third reason arose from the effects of the strategic and political split of Scandinavia earlier in 1949. As the cold war showed no signs of easing up, Sweden was politically left in relative isolation compared to Norway and Denmark. All possibilities of overcoming the potential disadvantages of this split in the context of the cold war were welcomed in London. Increased cooperation in the economic field was one of these and therefore economic cooperation and integration were again entangled with the cold war.

The immediate reason for calling up the representatives of the countries to discuss

${ }^{1}$ Playfair to Copleston, 26.10.1949, T 236/5370.

${ }^{2}$ Address by Sir Henry Wilson Smith, HP $\AA$ 64, Vol. HP 2216. 
further economic cooperation was provided by the US economic aid administration, when it increased pressure for the establishment of regional economic groups in Europe, such as Benelux, Finebel or a Scandinavian Customs Union. In autumn 1949, the ECA chief, Paul Hoffman, delivered a strongly worded speech for the OEEC Council, in which he said that the US Congress would not accept continuance of the recovery program without clear determination by the Europeans to move towards economic integration. ${ }^{1}$ On 2 November, the Ministerial Council of the OEEC adopted a resolution, in which 'the desirability was recognised of promoting regional economic groupings' ${ }^{2}$ From the US viewpoint, this seemed on the short term to open the best prospects for further integration of the European economies.

The general approach of the British and the Scandinavian governments towards questions dealt with in the OEEC had been very similar in 1948-49. In organisational questions, they all had been firmly against the idea of a strong independent supranational bureaucracy or the suggestion of a 'superman' as a head of the permanent organisation in $1947-49 .{ }^{3}$ In questions of world-wide liberalisation of trade especially, the Swedes were on the same principal and practical lines as the British. The approach towards internal financal problems was remarkably similar in all these countries, save perhaps Denmark's lesser preoccupation with full employment policies. ${ }^{4}$ Otherwise the domestic economic policy of maintaining price stability in a full employment economy by Keynesian demand management using budgetary means, was common to these countries.

1 UK OEEC telegram No. 1224 to FO, 30.10.1949, FO 371/78021; the full text of Hoffman's address is in FO 371/78022. Hogan, The Marshall Plan, 273 - 276; af Malmborg, Den ständaktiga nationalstaten, 90 - 91 .

${ }^{2}$ Henniker memorandum, 'Regional Economic Groupings. I Closer Economic Association between Norway, Sweden, Denmark, the United Kingdom and the Sterling Area', 12.12.1949, FO 371/78139.

${ }^{3}$ Milward, The Reconstruction of Western Europe, 171 - 211.

${ }^{4}$ 'The Internal Financial Policies of the Uniscan Countries', report by the Economic Section of the Cabinet Office, May 1950, FO 371/87090. 
Hence, as a rule, the British could find the Scandinavians on their side in OEEC discussions on economic policy.

This convergence of the basic economic outlook of the British and the Scandinavians, was compounded with a more deliberate policy of cooperation. In October 1949 the British representative to the OEEC Edmund Hall-Patch, to whom Dag Hammarskjöld affectionally referred as 'HP', suggested that this cooperation should be deepened by some special arrangement, agreed on the ministerial level, between the British and the Scandinavians in the work of the OEEC. ${ }^{1}$ Hall-Patch said to Hammarskjöld: 'I have told him [Cripps] that it is necessary to try and create "un petit noyau" of sensible people ... And the only few with which we can join now in such a group are the Scandinavians." A little later, Ellis-Rees informed the Treasury about Hammarskjöld's apparent interest 'that the U.K. and the Scandinavians can instill some new life into O.E.E.C. on sound lines' ${ }^{3}$

But perhaps the most enthusiastic proponent for closer Anglo-Scandinavian economic association in Britain was the Chancellor of Exchequer, Sir Stafford Cripps. Whereas Hall-Patch in the OEEC was an ardent supporter of closer Anglo-Scandinavian cooperation in organisational questions of European economic cooperation, Cripps took a somewhat broader view. For Cripps, Anglo-Scandinavian cooperation was not just a tactical ploy to manoeuvre into better positions in the Ministerial Council of the OEEC. It was for him an opening towards further economic cooperation in Europe, along lines that would build up Britain's economic strength in a way not inimical to current British or socialist - economic thinking and political traditions.

\footnotetext{
${ }^{1}$ Interview with Erik von Sydow (OEEC), 7.7.1970, Harry S. Truman Library, Oral History Interview Collection, Copy in NPCA. On 'HP's' and Hammarskjöld's friendship, Ingemar Hägglöf, Drömmen om Europa (Värnamo: Norstedts, 1987), 51.

${ }_{2}^{2}$ Dag Hammarskjöld promemoria, 28.10.1949, HP 64 Ä, Vol. HP 2216.

${ }^{3}$ Ellis-Rees to Dennis Rickett (T), 29.11.1949, FO 371/78137.
} 
Already in 1946, Cripps had pointed out to Gunnar Myrdal, that Britain and Sweden had a lot to profit from closer economic alignment:

The Government of this country and of Sweden now have many economic views in common. We are both inspired by the same desire to make this what $\mathrm{Mr}$. Henry Wallace called the century of the Common Man, and I trust that, whatever our immediate problems may be and however much our recent experiences may have tended to separate us, we shall from now onwards draw closer and closer together in our effort to benefit not only our own peoples but humanity throughout the world.

We both believe in a creed of Social Democracy, which is, I am convinced, the one means by which a virile and active democracy can survive in a world still full of totalitarian ideas. ${ }^{1}$

'On the side of the British Labour Party, illusions were rife about Scandinavia in general'. Thus, Alan Milward described the socialists' 'special relationship' over the North Sea in his monumental work The Reconstruction of Western Europe 1945-51. ${ }^{2}$ Socialists were faced with a 'hostile European world of revived and vigorous neoliberalism, supremely indifferent to what they thought of as their own uniquely successful experiment in modern governance. Where else could they turn for consolation other than to Scandinavia? ${ }^{3}$ Be that as it may, the British socialists were not only looking for consolation, but also for consolidation. Besides the pleasure of seeing other socialists holding governmental power, the Scandinavians figured prominently in Labour's view of possible alignments and re-alignments of power between the European nation states.

As was explained to Swedish and Finnish social democratic MP's in autumn 1948, when visiting London under the auspices of the Inter-Parliamentary Union:

\footnotetext{
${ }^{1}$ Cripps's speech at a lunch with Myrdal, undated (1946), File 420, Sir Stafford Cripps papers, Nuffield College, Oxford.

${ }^{2}$ Milward, The Reconstruction of Western Europe, 316.

${ }^{3}$ Ibid.
} 
Should de Gaulle take power in France, it would be probable, that cooperation based on the Brussels pact would become very difficult or in practice altogether impossible. Then a Labour-led England would find it absolutely necessary to establish cooperation not only with the Benelux-countries, but in particular with the Scandinavians. ${ }^{1}$

This view had previously in been expressed in Labour circles only, but by the end of the year also FO officials expressed this view informally. When de Gaulle would be in power was of course a different question. ${ }^{2}$

Leaving these speculations aside and returning to a more mundane level in Paris on 29 October 1949, Cripps elaborated his views of closer Anglo-Scandinavian cooperation to the Scandinavian foreign ministers. He highlighted that the British and the Scandinavians had a fundamental similarity of outlook towards the 'general problem, which was included in the talk of "economic integration" or "unification of Europe".'3 'It seemed to him that England and the Scandinavian countries had to a large degree a common conception of the question of economic policy and that we often distanced ourselves from the Latin peoples in these questions' ${ }^{4}$ This had led Cripps to the idea that, concerning the attempts within the OEEC to further regional cooperation, they could perhaps establish a closer economic association. Also the Netherlands would most likely be more interested in this kind of northern group than in the Latin countries, but was bound in Benelux. Also very important in Cripps's view was West Germany's future economic orientation, and if the Netherlands decided to join a possible northern group, he expected the Germans to follow on the same path. ${ }^{5}$ Undén, 'with to him unusual warmth', agreed with Cripps that the Swedes and the British had a common view on

\footnotetext{
${ }^{1}$ Wuori to Enckell, 9.12.1948, AFMFA.

${ }^{2}$ Ibid.

${ }^{3}$ Cripps minute, 2.11.1949, T 236/5370; Undén promemoria, 3.11.1949, HP 64 Å. Vol. HP

${ }^{4}$ Ibid.

${ }^{5}$ Ibid.
} 2216. 
economic policy in general. ${ }^{1}$ He shared the views about the importance of Germany and that they were interested to explore the field, as suggested by Cripps. ${ }^{2}$

Also Bevin's first reaction was 'on political grounds' positive and he agreed for exploratory talks with his Scandinavian colleagues in Paris. ${ }^{3}$ Bevin said that the proposals should be examined 'sympathetically' ${ }^{4}$ From the political point of view, a step ahead on the Scandinavian front seemed to bring certain advantages both as to allay US suspicions of British procrastination in further economic integration in Europe and to bring the Scandinavians, the Swedes in particular, closer to Britain by economic means. At the official level, enthusiasm was even more pronounced and various political advantages were seen in the plan. Consequently, FO support for Uniscan throughout the life of the body was mainly based on political grounds, and this proved decisive to its continuance. ${ }^{5}$ First, the scheme provided the British with a case to show the Americans that they were not opposed in principle to joining regional groups in Europe. The FO reasoning was as follows:

In view of the great interest shown by the United States Government and public opinion in the economic integration of Western Europe, and of the widespread feeling that the United Kingdom is a stumbling block to developments of this kind, it is considered important that we should actively promote to formation of such an economic group, provided that it does not cut across our wider interests, which our association with a Scandinavian group would not appear to do. It is, therefore, suggested that we should take the initiative in making proposals to this end. ${ }^{6}$

${ }^{1}$ Hägglöf, Drömmen om Europa, 53.

2 Östen Undén promemoria, 3.11.1949, HP 64 Å. Vol. HP 2216.

${ }^{3}$ FO telegram No. 1421 to UK delegation OEEC, 1.11.1949, FO 371/78136.

${ }^{4}$ Henniker minute, 17.11.1949, FO 371/78136.

${ }^{5}$ The Bank of England officials, for example, held the view that Treasury and FO enthusiasm behind the scheme was entirely based on political considerations. Lithiby minute, 8.11.1949, OV $29 / 31$.

${ }^{6}$ Henniker memorandum, 'Closer Economic Association between Scandinavia and the Sterling Area', 30.11.1949, FO 371/78137. 
Additionally, an economic association might 'strengthen the Scandinavians in overcoming their scruples about abandoning the policy of neutrality'. ${ }^{1}$ This applied especially to Sweden, but also to the Norwegian and Danish governments who were anxious to show their population that the abandonment of neutrality brought also some tangible advantages. The initiative came at a time when the actual military advantages of the North Atlantic Treaty were yet to materialise, but the costs of building up military strength were realised. Both the Norwegians and the Danes seemed to be lacking in confidence in their Western defence connection. The FO also reminded, that 'almost alone amongst the Europeans the Scandinavians have been consistently friendly towards us lately'. ${ }^{2}$ This had been most visible during the various disputes in the OEEC, when the British had found that their only allies had been the Scandinavians. Similar political considerations about the benefits of linking Sweden more firmly to Britain and its Scandinavian neighbours were held in Norway as well, where Arne Skaug, the Norwegian delegate subsequently handling the Uniscan negotiations and Smitt Ingebretsen, the conservative party leader, were of the opinion that the British proposals opened a good opportunity to prevent Sweden becoming more isolated. ${ }^{3}$ It would be another means to futher Scandinavian unity, a very popular concept among the Scandinavian electorates at large. And that concept had been dealt a hard blow in 194849 with the failures of the SDU and Scandinavian custom union -plans.

Political motivations notwithstanding, the scheme was an economic one and had to be studied on its economic merits. In Cripps's discussions with the Scandinavian foreign ministers it was agreed that the parties should come back to the issue after preliminary

\footnotetext{
${ }^{1}$ Henniker minute, 1.11.1949, FO 371/78136.

${ }^{2}$ Ibid.

${ }^{3}$ Villard (Oslo) telegram to Dean Acheson, 14.12.1949, SD, 857D.00/12-1449, NA, copy in Vol. 13. NPCA.
} 
studies had been made. ${ }^{1}$ The studies over the pros and cons of an Anglo-Scandinavian economic association were conducted in different Whitehall departments and in the Cabinet in November and early December 1949. It corresponded well with the tentative plans made earlier in the Treasury and the Bank of England for increasing economic cooperation with the Scandinavians. From an economic point of view, there did not appear to be any serious objections for closer economic association. ${ }^{2}$ The Scandinavian countries were those 'with whom economic association would be most natural for the Sterling Area'. ${ }^{3}$ The levels of trade and financial transactions were relatively high between the countries, and from that perspective an economic association made sense. There were no critical balance of payments difficulties with the Scandinavians, although the situation with Denmark and Sweden varied from time to time. Yet, these problems were dwarfed by the difficulties between Holland and Belgium, which were nonetheless together in Benelux. Furthermore, the economies of Britain and Scandinavia were largely complementary, providing each other with different products and raw materials. ${ }^{4}$

The Board of Trade also gave its initial consent to the idea, as the possibility of having the Scandinavians join the sterling area was especially attractive. ${ }^{5}$ At that time, roughly 45 per cent of Denmark's, 35 per cent of Norway's and 25 per cent of Sweden's trade was with the sterling area. Before the war the pattern had been very different because of German competition. The Board of Trade anticipated that this was likely to revive and 'it would therefore be in our interest to harness the Scandinavians to us before

${ }^{1}$ Berthoud to Coulson (UK deleg. OEEC), 2.11.1949, FO 371/78136.

2 Treasury memorandum, 'Scandinavia. The Financial Problems of closer Union', 8.11.1949, T 236/5370; Treasury memorandum, 'Scansa', undated, T 236/5371; Sharman Wright minute, 3.11.1949, OV 28/31.

${ }^{3}$ Henniker memorandum, 'Closer Economic Association between Scandinavia and the Sterling Area', 30.11.1949, FO 371/78137.

${ }^{4}$ J. P. E. C. Henniker minute, 1.11.1949, FO $371 / 78136$.

${ }^{5}$ Burrett minute, 2.11.1949, FO 371/78136. 
our trade with them starts to fall away'. ${ }^{1}$ A further attraction from the Board of Trade viewpoint was that closer economic relations with the Scandinavians would also be likely to reduce restrictions for British exports.

The British Uniscan proposals were formulated in the Trade and Payments SubCommittee in November. The British aims were mainly financial and dealt with the removal of restrictions on capital and current payments between the four countries. They suggested that the Scandinavian countries should associate themselves with the sterling area as 'non scheduled territories', although they would not take part in the gold or dollar pools. In effect, this would mean full freedom of currency convertibility and capital movements between the countries, which would in turn lead to a situation where both the sterling area and the Scandinavian countries would agree to hold each other's currencies without limit, i.e. would give each other unlimited short term credit. Among other things, tourist travel and cash allowances to both directions would be unrestricted. All this was hoped to lead to further liberalisation of trade, although no specific proposals were made on the trade side. In trade matters the OEEC framework was recognised of being the main frame of reference, and any agreements between the British and the Scandinavians would be in line with developments in the OEEC. In order to ensure proper consultation on trade and financial matters, the British suggested that an AngloScandinavian Economic Committee (Uniscan) should be established, which might take the place of the existing bilateral arrangements.

The British proposals specifically stated that the association should not be exclusive, as to allay mainly French suspicions, and that it should be 'as far as possible' nondiscriminatory except on balance of payments grounds. The arrangement 'must be open to accession by any like-minded country which accepts the conditions of membership and must in fact be a step towards the establishment of multilateral trade and free

\footnotetext{
${ }^{1}$ Henniker minute, reporting Board of Trade views, 4.11.1949, FO 371/78136.
} 
convertibility of currencies over the widest possible area'.' 'Like-mindedness' was defined by the Trade and Payment's Sub-Committee as similar thinking in respect for law and government authority, a sense of social responsibility etc. In the FO it was said that the Scandinavians had reached 'a comparable stage of social and political development to our own' and that they thought along similar lines and used similar methods. ${ }^{2}$ This exploration of the common 'volksgeist' among the British and the Scandinavians culminated in an assessement of the hallmarks of 'non-likemindedness'. Countries which adopted 'entirely different methods and policies' such as fluctuating rates of exchange, irregular gross-rates, inadequate control of dollar payments, a free market in gold or insistence on settlement of balances in gold, were not 'like-minded' ${ }^{3}$ This effectively left Belgium, Switzerland, France and Italy out.

The initial British proposals to the Scandinavians were only substantive in the payments and currency fields. Otherwise the British did not suggest any far-reaching concessions in the most important and difficult fields of tariffs and the allocation for export of scarce raw-materials such as coal. E. A. Cohen presented the Board of Trade view: 'whereas hitherto we have offered the Europeans coffee without milk, we are now inviting the Scandinavians to the preferential privilege of coffee without cream' ${ }^{4}$ On the other hand, from a bargaining point of view there was no reason to make concessions, or even hint about them, at this stage.

The preparatory work, the first Uniscan proposals and the related interdepartmental discussions also highlighted wider issues: Britain's general trade policy and attitude towards institutional cooperation, Anglo-American relations and Britain's policy towards

\footnotetext{
'Henniker memorandum, 'Regional Economic Groupings', 12.12.1949, FO 371/78139.

${ }^{2}$ Henniker memorandum, 'Closer Economic Association between Scandinavia and the Sterling Area', 30.11.1949, FO 371/78137.

${ }^{3}$ C. A. Duke minute, 15.11.1949, FO 371/78136.

${ }^{4}$ E. A. Cohen to Harry Wilson-Smith (T), 13.12.1949, FO 371/78139.
} 
its continental European allies. The first concern was the effect of an Anglo-Scandinavian economic association upon Britain's relations with the US. Even if, as it was generally agreed in Whitehall, an Anglo-Scandinavian bloc would be in accord with general US policy towards Europe, it was feared that it would merely seem to be a poorly disguised substitute for more important and constructive British initiatives with the major European powers. ${ }^{1}$ This might lead the Americans into cold-shouldering the Anglo-Scandinavian bloc in favour of a wider continental economic group. On the other hand, it was a step in the direction favoured by the Americans, that is, away from bilateralism and towards further liberalisation of trade. Removal of restrictions of capital transfers and exchange control barriers would be in accordance with this trend. ${ }^{2}$ Furthermore, Burrett in the FO believed that the Americans would in the end appreciate and be more favourable towards 'genuine U.K. - Scandinavian group based on realities, even if limited in scope, than on the kind of facade put up by the French and Italians in the Customs Union or on the kind of scheme which is likely to emerge from the Fritalux proposals' ${ }^{3}$ Also fears that the US would be more favourable towards a 'liberal' economic bloc in the European continent than a 'social democratic' Anglo-Scandinavian bloc were not necessarily well founded. Both Britain and Scandinavia had strong connections and popular sympathies in the US, and in R. W. Jackling's words 'a U.K.-Scandinavian line-up would have a great deal of sex-appeal' . ${ }^{4}$

The first soundings with the Americans confirmed the view that the US would welcome a Anglo-Scandinavian group. Officials in the ECA were in general supportive about the plan, seing it as 'an extremely important and useful first step towards that new

\footnotetext{
E. A. Radice minute, undated, FO 371/78136.

${ }^{2}$ Franks telegram No. 5701 to FO, 7.12.1949, FO 371/78138.

${ }^{3}$ Burrett minute, 8.11.1949, FO 371/78136.

${ }^{4}$ R. W. Jackling (Economic Relations Dept.) minute, 10.11.1949, FO 371/78136.
} 
form of European Economic Organisation which they very much wanted to see' ${ }^{1}$ The British described the initial feelings among ECA officials as 'one of great enthusiasm as though this was the moment when a glimpse of Paradise would at last be attained' ${ }^{2}$ After the British revealed the actual details of their plans, the temperature dropped somewhat, but ECA support was assured.

More difficult, however, was to assure wider American political opinion, especially Congress, about the advantages of such limited regional cooperation. Some ECA officials warned the British that their plans would not be very useful for purposes of Congressional presentation. The Uniscan proposals might not be quite enough to assure the Congress about British aims concerning European integration. The fact that Western Europe seemed to be fragmenting into separate economic blocs also opened worrying prospects. $^{3}$

Consequently, Uniscan's effects on Britain's relations with the continental European powers had to considered carefully. Radice feared in November 1949 that 'any attempt on our part to push ahead with the Scandinavians will make it virtually certain that France, Italy and the Benelux Powers will get together with their regional plans and that Western Germany will seek to join them' ${ }^{4}$ This would virtually divide Western Europe in two economic camps. The first would have included 'the champions of the Welfare State', and the second 'those in favour of liberal economies'. However real these differences with Britain and its continental allies were, for the sake of Western unity Radice did not want to over-emphasize them. ${ }^{5}$ However, it seems unlikely that any initiative on the Anglo-Scandinavian front seriously influenced or hastened the drive

\footnotetext{
' Franks telegram No. 5739 to FO, 9.12.1949, FO 371/78138.

${ }^{2}$ Christelow to Playfair, 13.12.1949, FO 371/78139.

${ }^{3}$ Ibid.

${ }^{4}$ Radice minute, undated, FO 371/78136.

${ }^{5}$ Ibid.
} 
towards Franco-German understanding, as its motivations were grounded on issues directly related to France's and Germany's own economic and political problems. ${ }^{1}$

A decision 'to go off into a huddle with the Scandinavians' nevertheless had considerable effect on Britain's European policy. It is clear, that this was understood in the FO, and from the Western Department came words of caution. Even if the scheme was to be the first step Britain would take in the economic field to meet the call for integration, Evelyn Shuckburgh warned that Britain's 'present political obligations are towards France, Benelux and the other Atlantic Pact countries in that order' ${ }^{2}$ If Britain decided to proceed with the Uniscan proposals without taking the Brussels Pact countries into account, the plan might seem as further evidence of Britain's growing distance from its continental allies and another move to 'contract out of Europe'. ${ }^{3}$ On the other hand, if Uniscan was to supplement other regional groups in Europe, Britain's position would be easier to defend. In any case, it was seen as most important to keep the French in the picture and try to explain the Anglo-Scandinavian plan 'as simply a part of the pattern which we see emerging for Europe'. ${ }^{4}$ It was also essential to avoid giving the impression that the British were going further with the Scandinavians than elsewhere in matters concerning exchange of information of internal financial policies, budgetary planning etc. 5

Another issue influencing Britain's relations with its European allies was the possibility that the emergence of an Anglo-Scandinavian economic association would set up a 'tremendous pull on the Netherlands to move in this direction', and thus endanger

\footnotetext{
1 See further, John Gillingham, Coal, Steel, and the Rebirth of Europe. 1945-1955. The Germans and the French from Ruhr Conflict to Economic Community (Cambridge: Cambridge University Press, 1991).

${ }^{2}$ Schuckburgh minute, 15.11.1949, FO 371/78136.

${ }^{3}$ Ibid.

${ }^{4}$ Ibid.

${ }^{5}$ Treasury meeting minutes, 12.12.1949, FO 371/78138.
} 
the Benelux scheme. ${ }^{1}$ In November 1949 it was anticipated in the Foreign Office that the establishment of an Anglo-Scandinavian economic group might lead to 'some wider grouping of the Northern European countries, eventually embracing Germany and the Netherlands, which would be parallel with a similar Latin grouping comprising Belgium, France, Italy and possibly others'. ${ }^{2}$ This would lead to Western Europe's division in two, leaving the more 'like-minded' northern Europeans in the same bloc. The British view was that the Dutch would prefer an association with Britain rather than with the French and the Italians. Illustrating British confidence about their decisive influence in European questions, the Cabinet's Trade and Payment's Sub-Committee was anxious that the British should do nothing which would look like an attempt to break up Benelux, or to prejudice the Finebel proposals. ${ }^{3}$

The other big question was where would West Germany be in these plans. Officials in Whitehall were also airing a wider plan which would be based on an AngloScandinavian association combined with the Netherlands and West Germany. ${ }^{4}$ The danger involved with West Germany's participation in the Anglo-Scandinavian association was - besides dividing Western Europe economically in two - that Germany's economic pull might eventually upset the political balance of the association. The initial political gains achieved by German participation, would be countered by the economic and financial disadvantages for British interests which would soon follow. ${ }^{5}$ The British, after all, were going into the scheme as the senior partner, with the smaller states in a more subordinate role. Thus, the Trade and Payments Sub-Committee agreed that West Germany would be excluded from the plan. It was believed that this would also be the decisive factor for

\footnotetext{
1 Jackling minute, 9.11.1949, FO 371/78136.

${ }^{2}$ Henniker minute, 1.11.1949, FO 371/78136.

${ }^{3}$ C. A. Duke minute, 15.11.1949, FO 371/78136.

${ }^{4}$ Berthoud to Hitchman (T), 9.11.1949, FO 371/78136.

5 J. B. Richards minute (German political dept.), 2.12.1949, FO 371/78136.
} 
the Netherlands' decision. ${ }^{1}$

One of the most powerful arguments in favour of further Anglo-Scandinavian economic cooperation was that Britain needed to show that it had kept to its word about its commitment to regional economic groups as a desirable objective. Cripps had confirmed this to both domestic and international audiences, but words needed to be supplemented with actions. Burrett in the FO minuted that it could hardly be argued, if Uniscan came into being, 'that we should be acting as rather bad Europeans if we associated ourselves with a regional group which would after all be based in that similarity of outlook and economic structure which is the only logical foundation for any regional groups' ${ }^{2}$ In his view, there was no other serious alternative for Britain, because participation in the regional group including Belgium and Italy would be more difficult for Britain 'for obvious reasons'.

The FO view, that on political grounds the creation of a Scandinavian regional group with British association was a desirable development, was shared by the Treasury and the Board of Trade. The discussions in the Cabinet's Trade and Payments Sub-Committee centered around the arguments on 'how this association could be brought about, and not whether it should be'. ${ }^{4}$ The Cabinet gave its approval for starting negotiations with the Scandinavian countries on 1 December 1949. The outline of the project was made public on 6 December, which was followed by keen attention in the press. ${ }^{5}$ From now on the British held the initiative. The first round of discussions at official level were to begin in Stockholm on 15 December.

${ }^{\prime}$ Duke minute, 15.12.1949, FO 371/78136.

${ }^{2}$ Burrett minute, 8.11.1949, FO 371/78136.

${ }^{3}$ Ibid.

${ }^{4}$ Duke minute, 8.11.1949, FO 371/78136.

5 'Scandinavian and Sterling Area - Possible closer association', The Times 6.12.1949; 'Closer bonds with Scandinavia - British economic proposals', The Times 7.12.1949; 'Britain plans new trade group - Proposals to Scandinavia - Meeting likely in few days', Daily Telegraph 7.12.1949; 'Britain's offer to Scandinavia - Trade and Finance', Manchester Guardian 7.12.1949. 
No spectacular advances were made in the first talks, although nobody expected this to happen yet. At this stage the British could only offer to relaxe capital and currency transfers, but the success of the removal of financial barriers between Britain and the Scandinavian countries was ultimately dependent on the degree of equilibrium in the trade between the countries. Most important was how the discussions revealed that the British proposals would actually increase the existing disequilibria and probably lead to further increases of sterling balances in Sweden and Denmark: in plain words, a further increase of the credit they were already giving to Britain. ${ }^{1}$ Not surpisingly, this made the Swedes especially apprehensive lest they came to finance the whole scheme, and so were more keen to find out what the British could give them in return in trade matters. Most important was British exports of coal, which had not been touched upon in the preliminary discussions. Indeed, trade was scarcely mentioned in the first round of discussions. ${ }^{2}$ In the end, the officials agreed that the present economic circumstances did not allow the complete removal of all restrictions on payments between the four countries, but that there was scope for more limited action which should be studied further.

Also, as it was evident that the US pressure for regional trade groups was relaxing towards the end of 1949 , the possible achievements in Uniscan had less sales value as examples of British steps towards integration from a Congressional or ECA point of view. The most important arena was the wider OEEC front, where both the British and the Scandinavians had been ever less enthusiastic to follow the Franco-American lead.

The second round of talks took place in London between 16-21 January 1950, again on high official level. The declaration setting up the Anglo-Scandinavian Economic Committee was signed in Paris on 30 January 1950 six months before Schuman Plan,

\footnotetext{
${ }^{1}$ Berthoud memorandum, 'Ukiscan', 20.12.1949, FO 371/78139.

${ }^{2}$ Playfair to Christelow, 20.12.1949, FO 371/78139.
} 
when Cripps and the Scandinavian foreign ministers approved a report by officials recommending closer economic cooperation between their countries. ${ }^{1}$ Uniscan was not based on a state treaty, and this emphasised the flexible and non-ceremonial nature of the arrangement. On 31 January the Council of the OEEC was formally informed about its establishment and about the first steps towards payments relaxations within the group. ${ }^{2}$ It was agreed that restrictions on current payments should be removed, and that some relaxation of capital payments should begin. ${ }^{3}$ The practical meaning of this was that tourist allowances were increased without limit. The exception was Norway, which retained some controls over its cash allowances. The main function of Uniscan, which consisted of officials of the four countries, was 'to keep under review the carrying out of the financial recommendations and to explore further possibilities for economic cooperation'. 'The body would work on a permanent basis, meeting on regular intervals in each capital. From time to time, it was anticipated, meetings of ministers would be called..$^{5}$

Despite considerable political goodwill behind the scheme, the economic achievements of Uniscan fell short of the original British proposals of November-December 1949 , when a more comprehensive financial liberalisation had been envisaged. ${ }^{6}$ Had this approach been successful, the pound sterling would in fact have both become convertible within this group and become the currency of inter-Scandinavian settlements. This would have directly strengthened the economic influence of Britain in Scandinavia, whose

\footnotetext{
${ }^{1}$ Agreed Minute, 30.1.1950, FO 371/87088.

${ }^{2}$ Report by the Uniscan countries to the Council of OEEC, 'Further measures of cooperation: Anglo-Scandinavian Arrangements', 31.1.1950, C(50)41, microform 049, OEEC Archives, Historical Archives of the European Communities, Florence.

${ }^{3}$ Report by Officials, 21.1.1950, FO 371/87087.

${ }^{4}$ C. W. Baxter to Bjarni Benediktsson (Icelandic Minister for Foreign Affairs), 30.1.1950, FO $371 / 87086$.

${ }^{5}$ Report by Officials, 21.1.1950, FO 371/87087.

${ }^{6}$ FO telegram to Oslo, Copenhagen and Stockholm, 3.12.1949, FO 371/78137.
} 
situation would then have resembled that of the sterling area countries. Of course, no dollar or gold reserves would have been pooled, and Scandinavia would have had these flexible payments arrangements with the UK only, and not with other sterling area countries.

The results were still modest on the financial questions, but politically the decision to establish the permanent committee, i.e. Uniscan, was more significant on the long run, even if it was not going to set 'the Potomac nor the Seine on fire'. ${ }^{1}$ That the achievements at this point were actually rather modest escaped the notice of the international press, which for a couple of days highlighted the significance of the emergence of the 'Northern bloc'.'2 Even Izvestiya in Moscow called attention to the 'economic alliance of the Scandinavian countries and Britain', which was called an attempt by the British ruling circles to 'strengthen their positions relative to the USA' and to secure 'at least Scandinavia as a monopoly of Britain' ${ }^{3}$ Jean Monnet, the French éminence grise behind European integration, took Uniscan and the dangers it contained for 'a division of Europe' up in a lengthy and serious conversation with Hammarskjöld. ${ }^{4}$

Monnet's fears were, in the end, of a political nature and over principle rather than about the actual economic implications of Uniscan. Indeed, when assessing the economic significance of Uniscan, it has to be remembered that the British approach to the prospects of an Anglo-Scandinavian economic association, were from the beginning fairly

' Plowden to Cripps, 23.1.1950, T 236/5373.

${ }^{2}$ More can be spent in Scandinavia', The Manchester Guardian, 31.1.1950; 'Economic Cooperation with Scandinavia'. The Times, 31.1.1950; 'Uniscan Agreement', The Economist 4.2.1950; "Uniscam"[sic] en Tête', Ce Matin 31.1.1950. The tabloid press coverage was somewhat more colourful: 'Spend-What-You-Like Holidays This Year. But only if you go to Scandinavia, Daily Mail, 31.1.1950; Scandinavia and Britain Sign Pact. Limit on Tourist's Cash Removed. Step Towards Closer Economic Ties. Telegraph, 31.1.1950; Holidays Will Be Happier for the Rich, Daily Worker, 31.1.1950.

${ }^{3}$ Izvestiya, 5.3.1950, in FO 371/87089.

${ }^{4}$ Hammarskjöld memorandum, 6.2.1950, HP $64 \AA$ A, HP 2216; Hammarskjöld to Brittain, 7.2.1950, FO 371/87088. 
modest on the actual trade side. ${ }^{1}$ A substantial benefit of the setting up of Uniscan was that even if the original financial proposals were not accepted but subjected to further study, a channel of economic cooperation had been opened up with the Scandinavians. An understanding was reached that the liberalisation of trade and payments between the countries required continuing cooperation to try and solve the basic disequilibria. This was hoped to lead to 'unspectacular but valuable progress' ${ }^{2}$ The British were satisfied to see an 'undoubted will to cooperate between all the members of the Group', which had political as well as economic significance. ${ }^{3}$

A cautious approach was also encouraged from the Swedish side. ${ }^{4}$ This was understood in London, and the British explained to the Americans that the idea behind the Uniscan was to avoid the mistakes of the Benelux, which had run into trouble by 'starting too ambitiously'. Once an initial agreement had been reached, the British hoped further steps could be taken. ${ }^{5}$ In the words of the liberal Stockholms Tidningen: 'nobody expected any immediate and tangible results from these preliminary talks. It is fair enough that the problems involving close economic collaboration between the four countries have been jointly discussed... ${ }^{6}$ The aims were not too ambitious, and thus the modest achievements in the economic sphere during the first phase of Uniscan should not be seen as a political failure.

Nevertheless, the political potential of Uniscan did have its limits. Soon after the first meeting of officials in Stockholm in December 1949, the British embassy reminded Whitehall that Uniscan's political importance would inevitably be limited by the Swedish

${ }^{1}$ J. E. Powell-Jones minute, 11.11.1949, FO 371/78136.

${ }^{2}$ FO telegram No. 749 to UK deleg. OEEC, 18.12.1949; Berthoud memorandum, 'Ukiscan', 20.12.1949, FO 371/78139.

${ }^{3}$ FO telegram No. 749 to UK deleg. OEEC, 18.12.1949, FO 371/78139.

${ }^{4}$ Ellis-Rees (Paris) to D. H. F. Rickett (T), 26.11.1949, FO 371/78137.

${ }^{5}$ Christelow to Playfair, 13.12.1949, FO 371/78139.

${ }^{6}$ Lambert to Bevin, 22.12.1949, FO 371/77716. 
government. Lambert said that neither Undén nor Hammarskjöld had said anything that would have suggested a departure from their government's cautious policy of freedom of alliances. ${ }^{1}$ The view in London about Swedish motivations for taking part in Uniscan was nevertheless more optimistic. ${ }^{2}$ It was well understood that Sweden's willingness to participate in the discussions did not imply any departure from its previous policy of nonalignment. The scheme provided the Swedish government with an opportunity to maintain Scandinavian cooperation and unity, and to counter the setbacks of the failures of the Scandinavian defence and customs unions. ${ }^{3}$ Etherington-Smith thought that the real motive behind Sweden's participation in schemes of this kind was the need to assure Swedish public opinion that the country was not completely cut off from the rest of the Western Europe, whilst cooperation did not entail political commitments with respect to the East-West bloc divide. ${ }^{4}$

Besides bilateral trade and financial issues between the British and the Scandinavians, the economic success of the Uniscan depended on wider issues as well. From the British point of view, there were three main themes running alongside its attempts to deepen its economic relationship with the Scandinavians. On the liberalisation of trade, the main progress was being made in Paris at the OEEC. Measures taken by the OEEC during the last months of 1949 modified Britain's position in bilateral trade negotiations with its continental trading partners as liberalisation of trade within the OEEC limited the scope for granting concessions in bilateral negotiations. In other words, Britain could offer very little to the Scandinavian countries that they did not already have. ${ }^{5}$ Set against this, it was agreed during the Uniscan discussions in December-January, that at the moment no

\footnotetext{
${ }^{1}$ Lambert to Harrison, 22.12.1949, FO 371/87086.

${ }^{2}$ Bolton minute, 19.1.1950, T 236/5373.

${ }^{3}$ On the Scandinavian Customs Union plan, af Malmborg, Den ståndaktiga nationalstaten,

${ }^{4}$ Etherington-Smith minute, 29.12.1949, FO 371/87086.

5 'Trade with Europe', The Financial Times, 23.1.1950.
} $88-93$. 
useful results could be achieved by separate discussions in the Anglo-Scandinavian framework.

Second, talks about ending financial restrictions between Britain and Scandinavia took place at the same time as proposals for a European Payments Union were being launched in Paris. ${ }^{1}$ It was realised that any concessions made within Uniscan might have less value if there was an effective arrangement covering Western Europe as a whole, backed by Marshall aid dollars. Later during 1950, this process completely overtook the liberalisation process within Uniscan, but it can be argued that by January 1950, prospects for a wider arrangement made the British and Scandinavian negotiators concentrate on issues outside the potential European Payments Union.

But perhaps the main limiting factor allowing Uniscan to become a more widereaching economic arrangement was the question of the West German economy. The re-emergence of West Germany as a supplier in international markets challenged Britain's position as a large-scale supplier of industrial goods throughout Europe. ${ }^{2}$ The Scandinavians were keen to use their accumulated sterling for West German goods, and were hesitant about joining any bloc in which West Germany was not a member. The West German markets were also becoming more and more lucrative for Scandinavians, and in particular for Danish agricultural products that had previously flowed to Britain.

Faced by these challenges, Cripps tried to instill more life into the Uniscan concept in January 1950 before the meeting of ministers in Paris, where the agreed minute establishing Uniscan was signed. He continued to stress the importance of developing such cooperation further. To Hammarskjöld, who was the Swedish representative in

' For the EPU see, Alan S. Milward, The Reconstruction of Western Europe, 299 - 334; Hogan, The Marshall Plan, 291 - 335, 349 - 359.

${ }^{2}$ On Swedish- W.German trade, Martin Fritz, 'Turbulente Jahre. Schwedens Außenhandel und Wirtschaft 1945-1954', Ulf Olsson (ed.), Neuanfang. Beziehungen zwischen Schweden und Deutschland 1945-1954. Sieben Beiträge (Umeả: Umeả Studies in Economic History 13, 1990), $143-164$. 
Uniscan meetings, he said on 19 January that after the establishment of Uniscan, British and Scandinavian ministers should come together for a longer meeting, prepared by officials, sometime during spring 1950, and there, long-term cooperation plans could be discussed and developed. Hammarskjöld advised his government to take a positive view regarding Cripps's initiatives. ${ }^{1}$ What concrete steps Cripps had in mind besides financial and payments liberalisation, remained unclear, but there is no doubt that he wanted to go further than what had been achieved by January 1950 .

The momentum was hard to maintain not only because of the wider economic processes undercut Uniscan's potential. The Labour Government was heading towards a general election and this was not the best of moments to break new ground in such a controversial issue as policy towards Europe. But more ominously for the long term, Cripps himself, his health ailing, had passed his peak as chancellor. Although he was the primus motor behind the Scandinavian orientation of British policy, his powers were not enough to keep it running after the initial push. Ernest Bevin, the other architect of closer cooperation with the Scandinavians was absent from the scene of Anglo-Scandinavian economic cooperation after the establishment of Uniscan. Of course, this was Cripps's sphere, and Bevin's only personal intervention at this stage was over a highly delicate dispute about cutting British coal exports to Scandinavia. ${ }^{2}$ This intervention secured Scandinavia's supplies of British coal despite the drastic measures of the Ministry of Fuel and Power, and was very much in line with the general policy of fostering closer economic and political cooperation with the Scandinavians. But if Bevin's political support in the background was a necessary condition for the fulfilment of Cripps's ideas about Uniscan, it was not sufficient. A stronger political will was lacking and no-one in Attlee's Cabinet was ready to take on the initiative Cripps failed to push further.

\footnotetext{
'Hammarskjöld to Undén, 19.1.1950, HP 64 Å, Vol. HP 2216.

${ }^{2}$ Bevin to Attlee, 7.11.1949, PREM 8/961; idem., 30.8.1950, 28.10.1950, FO 800/500.
} 
There is no doubt that Uniscan's influence on economic realities was very small, even for the participating countries, not to mention Western Europe as a whole. ${ }^{1}$ The British could not afford any real economic concessions, especially in the trade field. However, this critique which concentrates on the economic side of the Uniscan misses the point: notwithstanding the economic terminology and windowdressing, the organisation's main function was political, not economic. It was established to coordinate and consolidate Anglo-Scandinavian policies in the OEEC and towards economic integration in general, as a sign of Britain's 'constructive attitude' towards Europe, and to provide a specific institutional link with neutral Sweden.

The political utility of Uniscan was already evident to some Swedish journalists in 1949 , when they wrote that in Uniscan, 'politically there would be a group of countries with much in common including a certain disinclination to be too much engaged in the many problems of Continental Western Europe'. These 'problems' included the supranational vision of an economically and politically integrated Europe.

\section{A role for Uniscan}

In January 1950, the officials could agree only on a basis of a more minimalist approach. Hammarskjöld summed up the essential problematic of Anglo-Scandinavian economic cooperation accurately when he said after the first round of officials' talks in December 1949 that it was mainly a question of finding some lowest common denominator down to which each country was willing to go. ${ }^{3}$ This did not promise any far reaching compromises, and subsequently led to only modest achievements on the actual economic

\footnotetext{
${ }^{1}$ Milward, The Reconstruction of Western Europe, 318.

${ }^{2}$ Lambert telegram No. 26 to FO, 7.12.1949, FO 371/78138.

${ }^{3}$ Berthoud memorandum, 'Ukiscan', 20.12.1949, FO 371/78139.
} 
field. In the second round of the officials' talks in January 1950, the lowest common denominator had been found: the liberalisation of tourist allowances.

After the over-enthusiastic start to Uniscan, the Swedes were afraid that the British government was losing heart about the idea of an Anglo-Scandinavian economic association as an important aspect of British European policy. The Swedish analysis of the situation was already rather pessimistic about British enthusiasm in the long term. They thought that when the British realised the complications of their original proposals for wider liberalisation of payments within the group and had had to accept a more modest start, their interest to the issue declined in direct proportion to the goals achieved. ${ }^{1}$ A further problem was that while the Swedes considered the long-term problem of the disequilibria in Uniscan trade as the crucial question behind any economic cooperation, the British seemed to lack the same sense of priorities. ${ }^{2}$ For the Swedes, what mattered was whether the British wanted to solve this problem or not. Nevertheless, uncertainty about the British long term interest in economic cooperation with Scandinavia led the Swedes to set greater value in Uniscan. Dag Hammarskjöld, a keen supporter of the Uniscan concept, became a central figure in maintaining the momentum in the project.

In November 1948, Cripps had told Hägglöf in London, that 'the Swedish delegate in the Paris-organisation took an impartial and helpful view. It is very valuable to have in Paris a person, who combines expertise and wisdom in a way that Hammarskjöld does'. ${ }^{3}$ 'He can talk about the European Payments Union, mediaeval wallpaintings, Swedish politics, T.S. Eliot, the woodpulp industry's problems \& Ibsen with equal

\footnotetext{
' Swedish memorandum (Uniscan delegation), 23.1.1950, HP 64 Å, HP 2216.

2 Ibid.

${ }^{3}$ Gunnar Hägglöf, Engelska àr 1950-1960 (Stockholm: P. A. Norstedt \& Söners Förlag, 1974), 224.
} 
knowledge \& enthusiasm but his real passion is botany...', continued the flow of praise about Hammarskjöld, culminating in Gladwyn Jebb's suggestion in 1953 for his appointment to become the general secretary of the UN. ${ }^{2}$

The work of the OEEC brought Hammarskjöld into close cooperation with the British. ${ }^{3}$ But despite the bonds of sympathy that were soon established between the British representatives and him, the usual complaint was that however well you know him, you can never produce more than a certain standard of clarity on delicate questions, especially questions involving Swedish politics.' ${ }^{4}$ Nevertheless, in the preliminary discussions about Uniscan between Ellis-Rees and the Scandinavian OEEC delegates in November 1949, the pivotal role of Hammarskjöld in any Anglo-Scandinavian arrangeinent was emphasised. The Swedish permanent representative in the OEEC, Erik von Sydow particularly stressed the importance of getting Hammarskjöld's support behind Uniscan. ${ }^{5}$ Ellis-Rees advised London, accordingly, that Hammarskjöld was 'a very important person to convert on the Swedish side, in fact the most important person' ${ }^{6}$ Since the end of the war, Ellis-Rees wrote, 'he has shown constantly his belief in the need for a strong Western Europe and the essential part which the Sterling Area and the Commonwealth have to play in the economic recovery programme'. ${ }^{7}$ It was largely attributed to Hammarskjöld that Britain managed to have credit facilities from Sweden in the immediate postwar period. As long as the British did not 'tie him with political difficulties which run up against the neutrality policy of his present Ministers, he should

${ }^{1}$ Stevens to F. Bentham and Cordelia Stevens, 17.5.1952, Sir Roger Stevens Papers, Churchill College, Cambridge.

${ }^{2}$ Lord Gladwyn, Memoirs, 256 - 257.

3 Hammarskjöld to Beck-Friis, 5.11.1948; Hammarsköld to Ellis-Rees, 26.1.1949: Hammarskjöld promemoria, 21.2.1949, OEEC-Paris, Dag Hammarskjöld papers, KB.

${ }^{4}$ Ellis-Rees to Playfair, 30.11.1948, FO 371/71967.

${ }^{5}$ Ellis-Rees to Rickett, 26.11.1949, FO 371/78137.

${ }^{6}$ Ellis-Rees to Rickett, 29.11.1949, FO 371/78137.

${ }^{7}$ Ibid. 
do everything to promote the good work'. ${ }^{1}$ That was why it was important not to stress any formal links with the sterling area, but to emphasise the step-by-step approach to 'wider integration of the West, meaning freer trade and payments'.2

When, between December 1949 and January 1950, the Danes suspected that the whole Uniscan scheme was merely a tactical ploy by the British, and was no more than a counterproposal to the continental Finebel-scheme, Hammarskjöld intervened. ${ }^{3} \mathrm{He}$ assured Nils Svenningsen, the Danish ambassador in Stockholm, that the offer to establish a closer economic association with the Scandinavians, and not with the continental countries, was a unique opportunity that should not be wasted. ${ }^{4}$

The pivotal role of Hammarskjöld as a crucial contact on the Swedish side in Uniscan cooperation was well appreciated in Britain. In December 1950, after the second Uniscan meeting, Rumbold minuted that Hammarskjöld 'was our best bet in Sweden'. Hammarskjöld was considered as 'completely Atlantic-minded, he did his best at every turn to guide Sweden away from the path of neutrality, and he was powerful. Thus to a man like M. Hammarskjöld Uniscan may appear like an opening in the wall of a cell in which he finds himself imprisoned: he can look out through it at the outside world even though it is too small actually to pass through'. ${ }^{5}$ Hammarskjöld expressed these 'Atlanticminded', or even Anglophile, views in conversations with the new Chancellor Hugh Gaitskell and Deputy Under-Secretary Roger Makins. ${ }^{6}$

The FO's Northern Department was not surprised to hear that Hammarskjöld was expressing such a keen interest in Uniscan. It was understandable that 'Sweden, who has cut herself off from Norway and Denmark \& West politically, should want to maintain

\footnotetext{
${ }^{1}$ Ibid.

${ }^{2}$ Ibid.

${ }^{3}$ Hägglöf, Drömmen om Europa, 54 - 55.

${ }^{4}$ Ibid.

${ }^{5}$ Rumbold minute, 1.12.1950, FO 371/87092.

${ }^{6}$ Makins minute, 13.1.1951, FO 371/94261.
} 
\& even strengthen her links with the West in non-political fields' ${ }^{1}{ }^{1}$ This, for its part, fitted British policy well. The early hopes and expectations attached to Uniscan, meant for the FO, that failures to integrate Scandinavia together and to the British sphere of influence through political and defence cooperation might be remedied by gradual success in the economic field.

Even if there were serious practical problems in the liberation of trade and payments in the Uniscan area, and the British Cabinet seemed to fall away from their initial enthusiasm, on the official level the question was kept alive. But what was this body supposed to do? General trade liberalisation and payments questions were being considered within the wider OEEC context in Paris, and there was no point in trying to solve the same problems in the smaller group. In the field of international finance not much remained to be done because the three Scandinavian countries were already closely linked with the sterling area. There had been no suggestion of establishing a discriminatory trade group, the Scandinavians were not joining the imperial preference club, and a free trade area or a customs union were out of the question, at least for the time being. In February 1950 it was also expected that the new British Cabinet would be re-examining the whole question of its policy towards Europe. High-level decisions pending, the FO decided not to push new initiatives, such as those proposed for social services in Uniscan, for the time being. ${ }^{2}$ Cooperation would be developed through the financial measures envisaged in January 1950, not by building an Anglo-Scandinavian welfare state or common market.

Nevertheless, in February 1950 the Treasury, thus far the most unequivocal supporter of the Whitehall departments of closer cooperation with the Scandinavians, pressed for

\footnotetext{
${ }^{1}$ Etherington-Smith minute, 22.1.1951, FO 371/94261.

${ }^{2}$ Foreign Office Research Department memorandum, 'Possibilities for Social Co-operation within the Uniscan Framework', 15.1.1950; Minutes of an interdepartmental meeting at Treasury, 24.2.1950, FO 371/87088.
} 
an early Uniscan meeting. Sir Herbert Brittain from the Treasury wrote to Eric Berthoud in the FO that 'for reasons of morale we should not put it off too long'. ${ }^{1}$ Makins was also willing to maintain the momentum achieved and the FO began sounding out the Scandinavians about a new meeting. ${ }^{2}$ The Swedes, it was known, would almost certainly want to tackle the problem of trade disequilibria, to which the FO had no objection. ${ }^{3}$

Subsequently, the first Uniscan meeting was held at the Danish Embassy in Paris between 1-3 April 1950. The delegations, consisting of senior officials from the four countries, discussed organisational questions, actions taken in each country to implement the January declaration, and problems of economic disequilibria. The only tangible move forward on the financial side was the UK delegation's statement about steps for further relaxations of controls over possession of Scandinavian currencies in Britain. ${ }^{4}$ On the economic policy front, Swedish proposals for studies on disequilibria were linked up with the work which was being done within the OEEC 'harmonisation' resolutions. ${ }^{5}$

The first meeting set a pattern for the future Uniscan discussions: instead of spectacular advances towards Uniscan free trade, the agenda came to be dominated by 'European' and other wider international questions. In the first meeting there was only one 'European' question on the agenda, the forthcoming OEEC payments scheme. Characteristically, it was agreed that 'it was desirable that representatives of the four Governments in Paris should keep in close touch and discuss the various proposals for a European Payments Union with a view of ensuring that discussions in the OEEC of such proposals take due account of the objectives of Anglo-Scandinavian economic

\footnotetext{
${ }^{1}$ Brittain to Berthoud, 20.2.1950, FO 371/87088.

${ }^{2}$ Makins minute, 21.2.1950; minutes of an interdepartmental meeting 24.2.1950, FO 371/87088.

${ }^{3}$ Burret minute, 22.2.1959, FO 371/87088.

${ }^{4}$ UK OEEC delegation telegram No. 214 to FO, 4.4.1950, FO 371/87089.

${ }^{5}$ Makins to Berthoud, 3.4.1950, FO 371/87089.
} 
cooperation'. ${ }^{1}$ In practice this meant an agreement that 'these and other points should be followed continuously in an Anglo-Scandinavian group in Paris in which the U.K. Delegation will have the initiative'. ${ }^{2}$ This meant, that the previously informal cooperation of the British and Scandinavian delegations in Paris became institutionalised. By the same token, the British tried to reassure the Scandinavians that they would stand out against US pressure in the OEEC. Hammarskjöld agreed, and said that there was a need to 'form a really firm front' in the OEEC. ${ }^{3}$

Makins, who took part in the discussions as the FO representative, summed up the atmosphere by saying that there was 'no doubt that what one might call an "espirit de region" soon grows up, which colours the outlook towards wider European problems and acts as a moderate brake on the development of policy'. ${ }^{4}$ Although there was not much of substance on the agenda, there was also 'no doubt that the Scandinavian countries attach a great deal of importance to Uniscan', quite possibly, even more than the British. ${ }^{5}$

After a cautiously hopeful start, the next full session of Uniscan had to be postponed until the autumn of 1950. The Schuman plan had transformed the European scene after May and in the OEEC the advent of the European Payments Union had changed the context of Anglo-Scandinavian cooperation in the financial or payments sphere. In the summer, war broke out in Korea, beginning the first large scale military conflict since the end of the the war.

Between the first and second Uniscan sessions the usefulness and future role of Uniscan was reviewed in London. In June 1950 Herbert Brittain called for a review of the terms of reference of Uniscan, and whether it really covered the kind of activity it

\footnotetext{
' Hall-Patch telegram no. 214 to FO, 3.4.1950, FO 371/87089.

${ }^{2}$ Makins to Berthoud, 3.4.1950, FO 371/87089.

${ }^{3}$ Ibid.

${ }^{4}$ Ibid.

${ }^{5}$ Ibid.
} 
would undertake in the future. Brittain expected that in light of the EPU, 'the emphasis from now on may be more on the political side'. ${ }^{1}$ At this stage, Cripps made his last intervention on the future of his pet project. In early August he instructed that a ministerial meeting of Uniscan should be called. ${ }^{2}$ This and the future of Uniscan in general was discussed in an interdepartmental meeting on 28 September 1950 among Treasury, FO, Board of Trade and Bank of England officials. In the end, no Uniscan meetings of ministers materialised, other than the brief exchanges of views which were customary before or during the meetings of the OEEC Ministerial Council. The officials kept the question of Anglo-Scandinavian economic cooperation to themselves, and the next meeting was once more on the official level. By now Cripps and Bevin, who both favoured developing Uniscan further, were fatally ill and the political high-ground had shifted.

The main problem with Uniscan's terms of reference arose from the fact that the European Payments Union had now made its main functions largely obsolete. Uniscan's achievements this far had been the relaxation of restrictions on current payments and some capital transfers. The EPU did not affect the utility of these arrangements, but any further progress in Uniscan had been linked to the success which could be achieved in removing the payments disequilibria, and as was minuted in the FO, 'one of the main functions of the Anglo-Scandinavian Committee is to study how this can be done'. ${ }^{3}$ With the EPU, these considerations were no longer relevant, as they were dealt with on a multilateral basis in the Union. Later in September even the preferential treatment of tourist allowances in Uniscan came under threat from the OEEC, where a new code on the liberalisation of invisible transactions was being drafted, which eventually superseded

\footnotetext{
${ }^{1}$ Burrett minute, 27.6.1950, FO 371/87091.

${ }^{2}$ Serpell (T) to Jackling (FO), 1.8.1950, FO 371/87091.

${ }^{3}$ Burrett minute, 11.8.1950, FO 371/87091.
} 
bilateral or regional arrangements. ${ }^{1}$

'It seems, therefore, that the Uniscan countries should now take stock of the position and decide what redirection or change of emphasis is required', Burrett minuted, reflecting the mood in the FO, and agreed with Brittain that the emphasis 'should be more on the political side than it has been in the past'. ${ }^{2}$ There was already 'increasing tendency to use the Anglo-Scandinavian Committee as a convenient forum in exchanges of views on O.E.E.C. matters', and there seemed to be no reason why this should not be developed. ${ }^{3}$ Ellis-Rees from the OEEC delegation in Paris spoke in favour of developing and safeguarding Uniscan cooperation 'in view of the strong feelings displayed by the Danish and Norwegian delegates on the subject ... even though it does not produce much in material advantages, it has a political significance to them, they value the frequent consultation, and they obviously want some special arrangements to continue to distinguish it and keep it alive'. ${ }^{4}$

In Paris, Ellis-Rees continued to emphasise the importance the Scandinavians attached to the Uniscan 'and thought that the Uniscan countries could work together in preparing Uniscan views on such subjects as, e.g., liberalisation of tourism, "harmonisation" and the Stikker and Petsche plans'. ${ }^{5}$ The general sentiment in Whitehall about Uniscan was that it should continue its work, but 'there was some doubt as to whether meetings of the frequency previously envisaged would be necessary or desirable' . Significant however, was that in the interdepartmental meeting on 28 September, the FO 'had no view on the

' Ellis-Rees minute, 26.9.1950, FO 371/87091.

${ }^{2}$ Burrett minute, 11.8.1950, FO 371/87091.

${ }^{3}$ Ibid.

${ }^{4}$ Ellis-Rees minute, 26.9.1950, FO 371/87091.

${ }^{5}$ Serpell note to Brittain and Playfair, 29.9.1950, FO 371/87091. The Stikker and Petsche plans envisaged further liberalisation of trade in Europe. Bossuat, La France, l'aide américaine et la construction européenne, 728 - 731.

${ }^{6}$ Serpell to Playfair and Brittain, 29.9.1950, FO 371/87091; Serpell minute, 8.9.1950, T $236 / 5375$. 
matter at all', and that it had no ambitions in taking over the British chairmanship of Uniscan from the Treasury. ${ }^{1}$ The practical day by day coordination of activities of the Uniscan group was left to the delegations in the OEEC, where Brittain nevertheless called for a more active British leadership as the 'original architects of Uniscan'.2

The OEEC 'offspring' of Uniscan adopted a more active role in Anglo-Scandinavian economic talks from autumn 1950 onwards. The FO instructed Hall-Patch along these lines in October 1950, but was nevertheless reluctant to reduce Uniscan just as part of the 'Paris machinery'. ${ }^{3}$ Indeed, the leitmotif behind continuing this cooperation in the EPU era seems to have been a need for a more comprehensive exchange of views and coordination of policies in the OEEC, but also to be able to respond to any new developments such as the Schuman plan. To be effective, this also required coordination outside the daily work of the OEEC. Hall-Patch wrote from Paris again in October stressing the value of cooperation with the Scandinavians and referred to Scandinavian suggestions that 'the post-Korean situation made more necessary mutual discussion and harmonisation of economic policies and the reaching of an understanding about current problems in O.E.E.C. ${ }^{4}$

The reference to 'the post-Korean situation' meant, of course, harmonisation of economic policies in the light of the recent rearmament drive. Not surprisingly, this brought NATO and Sweden's official policy of neutrality into the picture. When matters related to Scandinavian defence were mentioned in this context, FO interest in Uniscan suddenly arose. Berthoud minuted in October that 'it may be awkward to discuss this question with Sweden whilst the economic aspects of defence are in any event likely to

\footnotetext{
I Ibid.

${ }^{2}$ Brittain to Serpell, 1.10.1950, FO 371/87091.

${ }^{3}$ FO telegram no. 1017 to OEEC Delegation, 3.10.1950, FO 371/87091.

${ }^{4}$ Hall-Patch telegram no. 849 to FO, 8.10.1950, FO 371/87091.
} 
be ventilated with the Danes and the Norwegians in the N.A.T.O. context'. ${ }^{1}$ But in contrast to FO views less than a month before, it was nevertheless recognised that 'the point of such discussion would therefore seem to be whether we wish to utilise the Uniscan forum to keep the Swedes in the picture on the economic repercussions of defence and to keep them as close to the N.A.T.O. line as possible'. ${ }^{2}$ The defence dimension spoke against leaving the OEEC delegations solely in charge of the Uniscan cooperation and Makins was strongly opposed to having the full Uniscan sessions in Paris. Also, as Makins continued, 'it will be much easier to talk with the Swedes about N.A.T.O. \& all that in the domestic plane of Uniscan, even if the subject may not be formally on the agenda'. ${ }^{3}$

The FO took accordingly stock of the value of Uniscan. Again, without expectation of any tangible economic advances in the future this was 'the political and imponderable advantages which we derived from the fact of its existence rather than to the actual results of individual meetings' ${ }^{4}$ Interestingly enough, Rumbold considered that 'these meetings are worth holding with undiminished frequency in order to foster the impression that the organisation is full of vitality even though their results may indicate the contrary'. 5 The tendencies of some Swedish and Danish participants to play down the role of the Uniscan, should also be countered, Rumbold minuted and 'the Norwegians would certainly be mortified if we took any steps to wind up or curtail the activity of Uniscan' ${ }^{6}$

Etherington-Smith from the Northern Department agreed that the value of Uniscan was mostly political: Uniscan was not only a link between the UK and the Scandinavian

\footnotetext{
${ }^{1}$ Berthoud minute, 10.10.1950, FO 371/87091.

${ }^{2}$ Ibid.

${ }^{3}$ Makins minute, 10.10.1950, FO 371/87091.

${ }^{4}$ Rumbold minute, 1.12.1950, FO 371/87092.

${ }^{5}$ Ibid.

${ }^{6}$ Rumbold minute, 1.12.1950, FO 371/87092.
} 
countries, but also a demonstration of inter-Scandinavian cooperation. 'Ever since Norway and Denmark joined the Atlantic Pact, Scandinavian has been split politically, a fact of which all three countries are uneasily conscious' ${ }^{1}$ In Uniscan, the British were playing godfather to the Scandinavians in their attempts to foster Scandinavian unity and solidarity, and this was a role that fitted conspicuously well with general British policy towards Scandinavia.

But that Uniscan was a political project required some rethinking of the FO role. If the economic side was minor, this would decrease both the Treasury's and the Board of Trade's interest in it. Therefore it would 'require some impetus' from the FO to keep it going. ${ }^{2}$ Makins agreed with these views and added that any move by the British government to discontinue or reduce its activities would do 'grave damage to our relations with the Scandinavian countries'. ${ }^{3}$ 'If it does us little positive good, it certainly does us no harm and from the political point of view I should say that there was advantage in keeping it going well' ${ }^{4}$ The Permanent Under-Secretary, Sir William Strang agreed with Makins.

Thus while still in summer 1950, after the establishment of the EPU, Uniscan seemed not to have useful grist to its mill, by early 1951 various developments spoke for the continuance of close Anglo-Scandinavian economic consultations. First of all, the Scandinavians themselves seemed to want this. Second, the British delegation in the OEEC favoured further openings on the Uniscan front. Third, the Treasury had not abandoned its original idea of closer economic association between the United Kingdom and Scandinavia. And last but not least, the Korean war, the subsequent rearmament drive, and the intensifying economic dimension of the cold war suddenly opened a

\footnotetext{
${ }^{1}$ Etherington-Smith minute, 22.12.1950, FO 371/87092.

${ }^{2}$ Berthoud minute, 28.12.1950, FO 371/87092.

${ }^{3}$ Makins minute, 2.1.1951, FO 371/87092.

${ }^{4}$ Ibid.
} 
prospect for the FO to use the Uniscan framework in its policy of integrating Sweden into the Western alliance system. From early 1951 onwards there existed a wide interdepartmental consensus about the usefulness of a distinctive Anglo-Scandinavian economic forum, a consensus at which the different Whitehall departments arrived despite their own particular interests.

Over the question of the future of the OEEC after the end of Marshall aid, the British were inclined to support the Swedish, who spoke strongly for preserving it as it 'still has valuable work to do, particularly in connexion with E.P.U. and the liberalisation of trade'. ${ }^{1}$ Nevertheless, its scope had diminished, and the British thought the machinery should be downsized accordingly. With massive rearmament, NATO had taken a more central role in decisions of production and investment. This brought the problem of Swedish official policy of neutrality into the picture again. If Sweden, in the end, was an integral part of both the military and economic defence effort of the West, it could not be left out of the forums of Western Economic cooperation. If OEEC's functions ceased or radically diminished, and the Council of Europe did not have much to do anyway, this would mean cutting off Sweden from the multilateral arena. 'The Scandinavians are concerned to avoid difficulties from the Swedes who are odd man out. They wish to keep an independent O.E.E.C. and would like to bring in the U.S. as a full member.'2 The British, nevertheless, preferred to leave the situation as it was, until the NATO-OEEC relationship became clearer. In the same vein, the British could not see much value in the work of the United Nations' Economic Committee for Europe (ECE), of which the Swedes had in 1947 been the most enthusiastic supporters, but felt 'obliged to support its continuance if only because its suppression would be regarded as a token of despair' ${ }^{3}$ The Scandinavians as a whole, saw the situation much in the same way and

\footnotetext{
${ }^{1}$ UK brief for fourth Uniscan meeting, undated (December 1951), FO 371/94262.

${ }^{2}$ Ibid.

${ }^{3}$ Ibid.
} 
'would certainly not wish to precipitate the demise of ECE'.'

Uniscan's role as an informal part of the wider network of treaties and alliances of the West was marked by the fact that it provided an channel to discuss the cold war's economic implications. During the rearmament drive from autumn 1950 onwards, the question of raw materials was particularly acute. In the second Uniscan meeting in November 1950 the Scandinavians were now particularly worried about the scarcity of some key raw materials. Significantly, the Swedish delegates could take part in the airing of views and information about studies made in NATO on the issue and their relation to the work of the OEEC. It was even recognized 'that in some case effective action might require co-operation from countries outside both Organisations'. ${ }^{2}$

In an informal meeting between Gaitskell and his Scandinavian counterparts in Paris on 12 January 1951, this dimension was discussed further. Again, without much difficulty of having an officially neutral country present among NATO-powers, 'a general and wide ranging discussion was held on the future development of O.E.E.C., its position and significance in Europe, and its relationship with N.A.T.O. ${ }^{3}$ Hammarskjöld made clear that the Swedes wanted to see the OEEC developed as the focal point of Western European economic cooperation, thus minimizing the risks of Sweden being left out due to its official foreign policy line. Nevertheless, Hammarskjöld also said 'that the objectives of the O.E.E.C. and N.A.T.O. were the same and that the O.E.E.C. should put the whole of its knowledge and experience at the service of the N.A.T.O'. ${ }^{4} \mathrm{He}$ himself was in 'full sympathy with the Atlantic concept which, from the Swedish point of view, was of course most easily expressed through the O.E.E.C. ${ }^{5}$ The differences

\footnotetext{
' Ibid.

${ }^{2}$ Record of the second session of the Uniscan, 23-25.11.1950, FO 371/87092.

${ }^{3}$ Note of informal meeting of Uniscan representatives, Makins, 13.1.1951, FO 371/94261.

${ }^{4}$ Ibid.

${ }^{5}$ Ibid.
} 
between neutral Sweden and Britain of their views towards NATO, OEEC and Western cooperation in general was described by Makins as a 'difference of emphasis' and not an unbridgeable gap. ${ }^{1}$ Hammarskjöld's remarks, however, have to be interpreted in the context of his and Undén's mutual understanding of the desirability to merge the different European non-military organs together, so as to keep Sweden firmly onboard of Western economic cooperation, but safely outside of its political or military manifestations. ${ }^{2}$ Despite Hammarskjöld's evident 'atlanticism', his ultimate loyalty in actual policymaking to Undén cannot be doubted, and that was also the contemporary British perception.

As if to show the British how his 'sympathy with the Atlantic concept' should be construed, Hammarskjöld said that he hoped 'ultimately for the sort of collaboration within Western Europe that had been successfully established within the Commonwealth' ${ }^{3}$ In this project, the OEEC would be a useful instrument on the economic side. If, as he hoped, the situation in Western Europe developed along these lines 'it would put the U.K. in its proper relationship to the United States. As the leader of Europe and the principal partner in the Commonwealth it would be in a most powerful position to knit together the North Atlantic community in the broadest sense'.

To the satisfaction of the British representatives, also Ernst Christiansen, the Danish finance minister, 'made some very robust statements and his general political outlook could hardly have been improved upon'. ${ }^{5}$ He stressed the need for Britain to act in concert both with Western Europe and the United States. 'London was in unique position with a window looking on to North America and by reason of this position could

\footnotetext{
${ }^{1}$ Ibid.

2 af Malmborg, Den ståndaktiga nationalstaten, $204-215$.

${ }^{3}$ Supplementary record of informal meeting of Uniscan representatives in Paris, 12.1.1951, FO $371 / 94261$.

${ }^{4}$ Ibid.

${ }^{5}$ Ibid.
} 
interpret Europe to America and vice-versa', Christiansen told Gaitskell and Makins. ${ }^{1}$

The significance of all this from the British point of view - besides its soothing effect on the battered self-confidence of the ruling elite of a great power in relative decline was that finally, after years of patient persuasion, it seemed that the main policy line of integrating the officially neutral Swedes and the officially aligned, but equally reluctant Danes into the general framework of Western cooperative framework, was bearing fruit. The traumatic experience of strong American pressure towards the Scandinavians in 1948-49 which resulted in the political and strategic division of the region, was being successfully healed. At the same time when Uniscan cooperation had helped to bridge the gaps left after events in 1948-49 in Scandinavia, and in Sweden's Western contacts, the countries were also loyal allies of Britain in questions of European economic cooperation. Britain was not left alone in its policy towards the emerging supranational organisations on the continent. Sweden was visibly coming in from the cold, both militarily and economically. Not only were Swedish views, epitomized by Hammarskjöld, much more in line with the general Western policy, but they were also in line with the nuances of British policy. Where else during these years after 1949 was British leadership still so strongly called for than in Scandinavia?

Mounting difficulties from the real economy

If the OEEC, the Schuman plan and other 'European' issues were harmoniously discussed in Uniscan meetings, the economic relationship between Britain and Scandinavia was more difficult by 1951 . Problems in the real economy could not be kept out of Uniscan discussions. While disputes over coal exports or fish landings had been

\footnotetext{
${ }^{1}$ Ibid.
} 
a long standing problem, there was now trouble on a wider front. ${ }^{1}$ In 1951 serious problems over Britain's balance of payments led to drastic cuts in imports, and this affected all the three Scandinavian economies in their vital export sectors. The economic situation the new Conservative government faced in late 1951 was, at least psychologically, not unlike the 'financial Dunkirk' outlined by John Maynard Keynes to the Labour government in August $1945 .^{2}$ 'Their story was of blood draining from the system and a collapse greater than had been foretold in 1931', as the new Chancellor, R. A. Butler later described the way in which his Treasury advisers explained the financial problems that laid ahead. ${ }^{3}$ If set in this context, British actions were not particularly harsh or aggressive on the Scandinavians only, as also other exporters suffered, but had an adverse effect on relations nonetheless.

The British used the Uniscan forum to mollify the Scandinavians, declared that they were well aware of the unwelcome consequences of import cuts 'for their Scandinavian friends', and hoped that conditions would permit their relaxation as soon as possible. Words were nevertheless not enough, and the temperature declined steeply when problems in Anglo-Scandinavian trade relations grew worse. That Britain's hitherto good relations with its Uniscan partners and the useful cooperation within that body were now threatened by problems in trade, was reflected in reporting from posts in Scandinavia. The new ambassador in Oslo, Michael Wright, warned the FO about the consequences to Anglo-Scandinavian relations of worsening trade relations during summer 1951. Norway and to a large extent Denmark and Sweden as well, constituted 'a democratic force on the northern flank with a social and political outlook very near to that of the

\footnotetext{
${ }^{1}$ Previous accounts of Anglo-Scandinavian trade problems are Nilson, 'No Coal without Iron Ore', and idem. 'Butter, Bacon and Coal'.

${ }^{2}$ Lord Keynes memorandum, 'Our Overseas Financial Prospects', 14.8.1945, CP(45)112, CAB 129/1.

${ }^{3}$ Lord Butler, The Art of the Possible. The Memoirs of Lord Butler (London: Hamish Hamilton, 1971), 157.
} 
United Kingdom and desiring ever closer relations with her'. ${ }^{1}$ In questions of European cooperation, the Norwegians especially, 'may be able, as they are certainly willing, to be of considerable help to His Majesty's Government'. If trade disputes, especially over Britain's exports of coal and steel to Scandinavia, were not solved quickly they would turn to other markets, particularly to Germany. 'New and different economic links will be forged which will inevitably as time goes by have considerable political implications', Wright warned. ${ }^{2}$

Makins added to these warnings in an important report 'Impressions of Scandinavia', which was circulated in the Cabinet in summer 1951:

It is obvious that the three Scandinavian countries are our staunchest friends and allies in Europe, though for the time being a reservations has to be made about Denmark. All three countries have a similar social and political outlook to the United Kingdom. Social democracy is strong; English is normally the second language; and there is profound sympathy for British life and culture. Our economic connexion with Scandinavia is both extensive and important. ${ }^{3}$

Norway was described as 'the most openly pro-British country in Europe'. Sweden, though neutral, was also 'staunch and determined to defend herself' and 'sympathetic to Western policies and anxious to be associated with them within the limits of a neutral position'. Denmark was at present 'in a thoroughly bad frame of mind'. It was frightened of Germany and Russia, regretting its entry to NATO and feeling nostalgic about the old Scandinavian neutralism. ${ }^{4}$ The disputes over British pricing policies seemed to be the last straw. All the more reason not to aggravate the situation further, and to continue to build up closer Anglo-Scandinavian relations as had been done during the first postwar years.

\footnotetext{
' Wright to Morrison, 25.6.1951, FO 371/94444.

${ }^{2}$ Ibid.

${ }^{3}$ Makins's memorandum, 'Impressions of Scandinavia', 28.6.1951, FO 371/94444. Nilson, 'No Coal without Iron Ore', 68 - 69 .

${ }^{4}$ Ibid.
} 
As to Europe, Makins reported that all the Scandinavians were anxious that the United Kingdom should take the lead in guiding Europe towards intergovernmental institutions. They disliked and distrusted 'the federalist and functionalist ideas of the French, Italians and Germans'. But if the federalist conception were to prevail, 'Norway at least might seek a much closer association with the United Kingdom and the Commonwealth'. ${ }^{1}$

The crucial issue was the current trade situation. The Scandinavians wanted, perhaps 'desperately' as Makins had said, to maintain their enlarged trading relations with the UK and the sterling area. The old prewar pattern of trade that had made Scandinavia more dependent on Germany, was not welcomed, but might have to accepted. 'There is the obvious danger that a return to the old economic pattern will bring with it a return to the old political pattern of hesitation and neutrality'. Scandinavian good will in supplying Britain with essential goods, might run out, if the British Government did not act. Makins called for immediate action:

It is no exaggeration to say that the securing and the consolidation of the northern flank of the Atlantic community depends basically on the ability of the United Kingdom to supply coal and steel in adequate quantities to the three Scandinavian countries.

Put even more simply, coal and steel exports are the key to the possibility of effective British diplomatic action in Europe in $1952 .^{2}$

If this was not taken care of, 'they will feel that we have let them down. Their cold houses, and perhaps some unemployment, will be a constant remainder of the failure of their British friends'. ${ }^{3}$ Strang joined him by saying that Makins's 'last two paras show that this is a sphere where economics lies at the very heart of foreign policy' ${ }^{4}$

${ }^{1}$ Ibid.

2 Ibid. Nilson, 'No Coal without Iron Ore', 69.

${ }^{3}$ Ibid.

${ }^{4}$ Strang minute, 28.6.1951, FO 371/94444; Nilson, 'No Coal without Iron Ore', 69. 
Despite warnings, that 'we have not too many close friends to lose', the difficulties could not be solved overnight. ${ }^{1}$ After much hard bargaining, larger quantities of coal and steel were secured for Scandinavia in late 1951, after a strong political intervention by the FO, but the continuing import restrictions led to further problems. The fifth Uniscan meeting between 24 - 26 March 1952 was completely dominated by disputes between the British and the Scandinavians over woodpulp prices. Especially the Norwegians, but also the Swedes, were taken aback by British attempts to push price levels down by concerted action with other European pulp-importers. Wright from the embassy in Oslo was again calling for moderation and consultation with Britain's Uniscan partners in February 1952. The Norwegians, especially, should be treated 'as being in a special relationship of friendship' with Britain. ${ }^{2}$ Anthony Eden spoke to Lange in a mollifying fashion on 11 March 1952 admitting that 'this was a matter on which we had not kept the Scandinavians as fully informed as we should have'. ${ }^{3}$ On the whole, the trade disputes were described by Eden as a 'bad business.' 4

Even if the British wished to avoid the discussion of difficult bilateral trade questions in Uniscan, which was better suited as a forum for large questions, the Scandinavians insisted that these problems should be tackled in it. Because of the 'combined political and economic importance' of trade disputes, the FO advised that the British should consent to this. ${ }^{5}$ However, with the introduction of the bilateral trade level, Uniscan's value as a discussion forum of like-minded intergovernmentalists declined. It meant that the forum became more introvert, whereas its most useful function could have been to look outside and concert Anglo-Scandinavian policies towards other European

\footnotetext{
' Wright to Morrison, 25.6.1951, FO 371/9444.

${ }^{2}$ Wright telegram No. 48 to FO, 8.2.1952, FO 371/99078.

${ }^{3}$ P. H. R. Marshall minute, 15.3.1952, FO 371/99080.

${ }^{4}$ Eden minute, 6.6.1952, FO 371/99082.

${ }^{5}$ Record of an interdepartmental meeting held in FO, 26.2.1952, CAB 134/1088.
} 
developments. On the occasion of the woodpulp disputes in 1952, Uniscan did serve a useful function as a 'safety valve' in ending the immediate disputes, as Michael Wright froin Oslo commented. ${ }^{1}$ But from a larger point of view, it was unfortunate that the energies of both British and Scandinavian decisionmakers concentrated on problems of Anglo-Scandinavian trade at a moment when very far-reaching decisions over European cooperation were being taken on the continent. At the same the ability of cooperation in the non-military sphere to influence Swedish neutrality policy was reduced at a critical moment, if the political capital invested in economic cooperation turned into a burden instead of advantage.

Eden, as his predecessors Bevin and Herbert Morrison had done, favoured good and close relations with the Scandinavians. However, the maintenance of the institutional links that had so painstakingly been established by the Labour government with Sweden, could not be taken for granted when Eden was in office. In early 1952, just as tension on the trade sphere was reduced, Eden introduced the idea of linking the planned European Defence Community (EDC) with existing European institutions. ${ }^{2}$ This created a serious problem for Sweden. ${ }^{3}$ Membership in European institutions with a military role was considered incompatible with neutrality policy. The prospect of Sweden's forced withdrawal from the Council of Europe if the Eden plan succeeded, again endangered hitherto cordial Anglo-Swedish relations, where in questions of European cooperation the countries had previously been very close to each other's viewpoints. These dangers were seen most clearly on the official level, and as Ambassador Sir Roger Stevens wrote from Stockholm:

... it would, I submit, be rash to assume that the undoubted Western sympathies

\footnotetext{
${ }^{1}$ Wright to Makins, 21.4.1952, FO 371/99081.

${ }^{2}$ Anthony Eden, Full Circle (London: Cassell, 1960), 47 - 48.

${ }^{3}$ af Malmborg, Den ståndaktiga nationalstaten, 268 - 284.
} 
of the Swedes are of such a nature that they would in all conceivable circumstances guarantee the retention intact of the present British connexion. There has grown up since the war, in Sweden as well as in the United Kingdom, the feeling that our two countries are closely linked by bonds of sympathy and interest. I believe it is no exaggeration to say that Anglo-Swedish relations are better now than at any time in the past. But this phenomenon is of quite recent appearance. There is no traditional friendship between us, as there is, say, between Britain and Belgium, or Portugal. Before the Second World War, Sweden's major European affinity was with Germany, and Britain took third place after France... On the whole, the present Swedish Government like to see eye to eye with Her Majesty's Government on all matters of general concern, if they possibly can. ${ }^{1}$

This, however, was not enough for Eden to modify his European policy. Overriding concerns over the future of West-Germany in particular, placed Sweden further down on the list of Britain's political priorities. ${ }^{2}$ Further, Eden was in general less interested in the different new multilateral forums of economic diplomacy that had emerged after the war, and his general disregard for the OEEC was witnessed by the Swedish ambassador who in their first encounter had to explain to the embarrassed secretary of state what those four letters stood for. ${ }^{3}$ In the end, the fact that the Eden plan never seriously endangered Sweden's attachment to European institutions was thanks to the French National Assembly, which rejected the EDC in 1954, and not to concerns over Britain's relations with Sweden.

In addition to this, however, in fostering closer ties with Sweden, no institutional arrangement or structure, formal or informal, could offset the harmful political effect the problems in the real economy created. As before the ERP, trade and economic cooperation as a foreign policy tool was a difficult one. It could easily turn against the

\footnotetext{
1 'Swedish foreign policy', Stevens to Eden, 18.3.1952, FO 371/100931.

${ }^{2}$ Dennis Allen minute, 23.4.1952, FO 371/100931.

${ }^{3}$ Hägglöf to Undén, 6.12.1951, Hp $1 \mathrm{Ba}$, Vol. 248. According to Hägglöf, Eden however became more interested in the OEEC later, Hägglöf to Undén, 16.12.1952, $\mathrm{Hp} 1 \mathrm{Ba}$, vol. 116. The Archives of the Swedish Ministry of Foreign Affairs (ASMFA), Stockholm.
} 
British themselves if the economic reality did not correspond with the good intentions. Britain's postwar economic condition was such that it made it certain that any possible political advantages would not be won easily. What was achieved in the Uniscan or OEEC level could easily be lost if the countries were involved in protracted trade disputes over their essential material needs. The goodwill gained at the European level in the OEEC and in Uniscan might be rapidly exhausted if the British trading methods and policies led the Swedes to accuse them of bad faith.

The importance of the political problems between Britain and its Uniscan partners arising from trade disputes, led the FO to draft guidelines, applicable for all Whitehall departments such as the Ministry of Materials that had been a principal troublemaker for the FO, about the conduct of trade negotiations and economic policy with the Scandinavians. As a sign that economic considerations were at the heart of FO's thinking of Britain's relations with the Nordic countries, it was said in a memorandum from June 1952 , that as the exports of wood products to Britain played such a preponderant part in the economies of Finland, Sweden and Norway, British import policies had 'far-reaching effects on our relationships, both political and economic, with these three countries'.' 'We are bound by special ties with Sweden and Norway as members of the AngloScandinavian Economic Committee' the memorandum continued. As a result, it had been agreed interdepartmentally in London and told to Britain's Uniscan partners, that Britain would in future consult in advance its Uniscan partners before any decisions about price levels. But by summer 1952, 'these efforts to apply U.K. policy in a manner least calculated to disturb relations with our Uniscan partners have failed', and most of the blame rested in the Ministry of Materials and in the Board of Trade. ${ }^{2}$

Thus in summer 1952, while acute disagreements between Britain and Scandinavia in

\footnotetext{
' FO memorandum, 'United Kingdom/Scandinavian Relations and Exports of Wood Products', 18.6.1952, FO 371/99082.

${ }^{2}$ Ibid; Strang minute 6.6.1952, FO 371/99082.
} 
trade issues were patched up, posts in Scandinavia and the FO had not been relieved from their fears about the future prospects of Anglo-Scandinavian economic cooperation. ${ }^{1}$ While on the trade side the British were slowly but steadily losing ground to West Germany, on the economic-political front by the early 1953 the Scandinavians were no longer as enthusiastic followers of Britain as they had been in the beginning of Uniscan cooperation in late 1949 . The changes in the real economy were working against, not for, further Anglo-Scandinavian economic cooperation. A case in point was that when the idea of full Scandinavian membership in the Sterling area was aired by the Treasury and the Bank of England in 1953, it met with less enthusiasm on the behalf of the Swedes and Danes than would have been needed to bring it about. ${ }^{2}$ Nevertheless, while the Board of Trade and the FO were trying to counter the overall trend, Uniscan remained a vital part of Britain's Scandinavian policy. Uniscan's meetings continued apace, but the trade disputes of 1951-52 were a warning sign that the British position towards its Scandinavian partners was not unproblematic, and that its leadership could and would not be taken for granted in the future if the economic basis of this relationship continued to erode.

If the economic scope of Uniscan was limited, and any developments towards this direction were hampered by the trade disputes of 1951-52, it remained a useful debating forum from 1953, if not much more. Uniscan's initial importance, nevertheless, was not confided to the economic field. Its political importance was repeatedly stressed in the FO. Primarily this meant cooperation and consultation in questions of international economic cooperation and European integration. But in the context of the cold war, its usefulness was seen particularly in defining Sweden's place between the blocs as a pro-Western

\footnotetext{
${ }^{1}$ For example, Wright to Eden, 18.6.1952, FO 371/99082.

${ }^{2}$ Brittain minute, 29.2.1953, T 236/5375; Bank of England memorandum, 'Uniscan and convertibility', 15.4.1953, OV 29/32; H. Eggers minute, 5.5.1953; Treasury memorandum, 'Scandinavia and the Sterling Area', 16.5.1953; Berthoud to Coulson, 17.6.1953, T 236/5375.
} 
neutral. Uniscan was also a part of the wider British policy towards Scandinavia, and it highlighted the fact that Britain had a special role there, even if the US was developing into the major strategic force also regarding Scandinavia. When the Labour government was replaced with a Conservative one in London in the autumn 1951, Uniscan provided one of the ways in which the close, personal relations between British and the Swedish policy makers could be carried on, despite the discontinuance of the special relationship of socialists in government. ${ }^{1}$

Ingemar Hägglöf, a Swedish diplomat, has summarised Uniscan's significance from the Scandinavian viewpoint:

The regular dealings tied the Scandinavians and the British also personally together. Two times a year leading officials in foreign, finance and trade ministries and central banks came together, and the meetings rotated between the four capitals. Occasionally also ministerial meetings took place. ... The Scandinavian participants already normally knew each other well from all the Nordic meetings, but through UNISCAN personal contacts could be made with colleagues from the British administration as well. There arose a comradeship in this circle: one had lived together and eaten and jested together, met each others families, been in correspondence, telephoned and was John and Leif and Hubert and Erling and Frank with each other. Social democrat under-secretaries from Scandinavia called Tory ministers "dear Derick" or Peter or "Reggie". In all issues of trade policy we came to belong to the British camp and were also considered by the outside world as a self-evident part of it. That is how it went for years. ${ }^{2}$

Uniscan's economic significance remained very limited until EFTA realised the original vision of an Anglo-Scandinavian economic bloc in 1960. But politically, in keeping together the Anglo-Scandinavian front in international economic cooperation and in establishing further links for Sweden's integration with the Western bloc as a whole, its establishment and the first years of its work should be seen as a success. The failures and

\footnotetext{
${ }^{1}$ Hägglöf, Drömmen om Europa, 56.

${ }^{2}$ Ibid.
} 
constraints in economic diplomacy were, nonetheless, balanced with advances in the strategic sphere. Before a final conclusion can be drawn of the relative significance of economic, financial, political and strategic considerations in Britain's policy, we shall have to turn back to the impact of the Korean war on Britain's search for a solution to Sweden's isolation in the realm of political and military security. 
If Britain's leverage in economic diplomacy remained limited well into the 1950s, other developments also highlighted Britain's reduced relative standing in the region. The most obvious was the fact that the US took such a central role in late 1948 and early 1949 in determining the ways in which the Scandinavian countries had to respond to the process of blocbuilding in the West. Most of the literature about Western policy towards Scandinavia during the period leading up to the signature of the North Atlantic Treaty has acknowledged British attempts to find a compromise between a completely neutral Scandinavian Defence Union and a strategically divided Scandinavia. ${ }^{1}$ The history of the failure of the British FO to find an alternative for the strategic division of Scandinavia has been well documented until early 1949. The story, however, did not end there. The British did not subsume their interests ungrudgingly to American preferences in 1949, but continued, in the words of the US ambassador to Stockholm, to 'keep their finger in the Swedish pie'. ${ }^{2}$ To bridge the differences in British and American policies towards Swedish neutrality became especially acute after the outbreak of the Korean war in 1950.

The previous chapters have shown how the British considered Swedish participation in any effective system of Scandinavian political, economic or defence cooperation to be crucial. Whether or not the Norwegians and the Danes joined the Atlantic pact did not change this basic view held in London. The COS had advised against Norway's and Denmark's adherence to the Atlantic pact without Sweden. ${ }^{3}$ If separated from the most important Scandinavian power, these countries were considered 'almost a pure liability',

\footnotetext{
${ }^{1}$ Lundestad, America, Scandinavia and the Cold War, 282 - 285; Turner, Britain, the United States and Scandinavian Security Problems 1945-49, 263 - 311; Skodvin, Nordic or North Atlantic Alliance, 58; Petersen, 'Britain, Scandinavia and the North Atlantic Treaty 1948-49', 260 $-262$.

${ }^{2}$ Butterworth to Acheson, 30.4.1952, SD, 758.5/4-3052, NA, copy in Vol. 19, NPCA.

${ }^{3}$ COS minutes, 19.1.1949, COS(49)10, DEFE 4/19.
} 
and if it was not for their shipping, other resources and the question of bases in Greenland, Iceland and Faroes, the scales would have weighed heavily against their participation in the North Atlantic Treaty without defence arrangements with Sweden. ${ }^{1}$ From a purely military point of view, even a neutral, Swedish led Scandinavian defence bloc was considered an attractive solution by the $\operatorname{COS} .^{2}$ In the FO, Jebb also shared this view, because unlike Collier in Oslo, he did not believe that a Swedish led bloc would in the end pursue a policy of appeasement of the Soviet Union. ${ }^{3}$ However, due to overriding political considerations, a strategically less satisfactory solution which led to a divided Scandinavia had to be accepted. This solution was considered better than no solution at all. ${ }^{4}$ It made political sense, but as far as Scandinavia was concerned, was military nonsense.

Despite - and because of - the problems ensuing from this split, Britain continued its tacit acceptance of Sweden's official policy of neutrality. It was understood, that while being officially nonaligned, Sweden would accept a degree of coordination and cooperation in military, economic and political issues, so its publicly pronounced policy of neutrality was less of a problem for Britain. Acceptance of Swedish neutrality also led to a relatively favourable arms exports policy towards Sweden. The remaining problems were with the limits of this cooperation and in how to influence Washington to bring its policy in step with the British.

' Hankey minute, 22.12.1948, FO 371/77391.

2 Bateman minute, 9.2.1949, FO 371/77398.

${ }^{3}$ Jebb minute, 17.1.1949, FO 371/77394.

${ }^{4}$ Kirkpatrick minute, 22.12.1948, FO 371/77391. 


\section{The groundwork for a tacit understanding}

When it was realised after the final shelving of the 'Hankey plan' in January 1949, that Scandinavia would end up strategically divided, hopes of finding a viable solution to the defence of the region first rested in the possibility that Sweden might find that 'a spell of unpleasant isolation' was enough to change its mind over its neutrality. Hankey hoped that a further reflection would move the Swedes to attach themselves 'in some way at a later date to the other Scandinavian powers', who would by then be rearmed and backed up by the Atlantic pact and 'make some private defence arrangements with them'. ${ }^{1}$ This view was endorsed by Bevin and introduced to the Cabinet in January $1949 .{ }^{2}$ In a memorandum prepared for the Cabinet, the Permanent Under-Secretary Sir Orme Sargent anticipated that it was fair to assume, 'that the Swedish Government will not really welcome a state of isolation and that they may in their own interest later on be brought to allow more or less confidential defence arrangements to be made between the defence authorities of the three Scandinavian countries' ${ }^{3}$

These hopes for Sweden's possible later adherence may at first seem to be wishful thinking, especially, if one considers the steadfastness of Swedish neutrality policy at the ministerial level, which Undén embodied. Nevertheless, there were signs that the future might not be as bleak as it seemed from the official government line in Sweden.

The signs of fracture in the monolithic picture of Swedish policy of neutrality were found in the two pillars upon which its execution was based: in the military establishment and among the officials of the Foreign Ministry. Both these groups were deeply concerned lest Sweden should become more vulnerable to Soviet pressure if it stayed

\footnotetext{
${ }^{1}$ Hankey minute, 22.12.1948, FO 371/77391; Hankey minute, 26.1.1949, FO 371/77392.

${ }^{2}$ Ibid.; Sargent memorandum, 'Scandinavian Defence and the Atlantic Pact', 22.1.1949, FO 371/77394.

${ }^{3}$ Ibid.
} 
outside the emerging Western alliance, or in isolation from its neighbours. ${ }^{1}$ These concerns were expressed remarkably openly with their British and American counterparts. The British, on their part, tried to use these channels to influence the Swedish government.

The idea of associating Sweden to the North Atlantic security system without its being a formal member of the alliance was not a new idea when it became a central feature of British policy in March-April 1949. The groundwork for a tacit understanding with the Swedes was already laid during the process leading to Norway's and Denmark's adherence in the pact. In the autumn 1948, the British had hinted to the Swedish ambassador in London, Gunnar Hägglöf, about a possible compromise between a neutral Scandinavian bloc and full membership in the Atlantic pact. Jebb aired this idea again in January 1949 in conversations with Hägglöf. He said that the Swedes were 'wrong in holding that there was no middle way whereby they might perhaps enter into certain arrangements with the Atlantic Pact countries'.

The British also made it clear that they were not saying that the Danes and Norwegians, as Atlantic pact members, could not make defence arrangements with the Swedes. On the contrary, they strongly encouraged them to do so. ${ }^{3}$ With the lessons of the Second World War in mind, Hankey suggested to Hägglöf that it would be also in Sweden's interest to make defence arrangements with Norway and Denmark to ensure that 'if for instance the north of Norway were attacked the Swedish Army would give what help it could in order to prevent the Russians occupying Narvik or even worse central Norway'. As to the possibility of reaching this kind of understanding, even if the Swedes upheld adamantly to their official policy of neutrality, the British 'did not wish

\footnotetext{
${ }^{1}$ Molin, Omstridd neutralitet, $30-45,63-82$.

2 Jebb minute, 13.1.1949, FO 371/77391.

${ }^{3}$ Hankey minute, 12.1.1949, FO 371/77392.

${ }^{4}$ Ibid.
} 
to slam any doors and would be quite willing to discuss these problems amicably'. ${ }^{1}$ For the time being, this did not lead to anything more substantial, but Swedish officials were in no doubt that the door for some kind of association with the Atlantic pact was left wide open, irrespective whether Sweden was officially neutral or not - and whatever the Americans might think.

From their discussions with Swedish diplomats and military authorities, the British could conclude that while the isolationists were unrepentant, the 'thoughtful Swedes', such as some Swedish diplomats, were not too happy about what was going on. Hankey reflected that 'we may hope that the Swedish attitude will improve in time ... particularly as we note that all their Service chiefs are on our side as well and are most anxious to make arrangements even quite privately with the Danes and Norwegians for the coordination of the defence of an area in which they are all equally interested'.2

The secretary-general of the Swedish Foreign Ministry, Hans Beck-Friis, had said in December 1948 that while the Swedish government would not drop its insistence on neutrality 'he hoped that some means could be found to keep the door open so that Sweden could come into an Atlantic Pact later perhaps as a non-belligerent partner' ${ }^{3}$ The Swedish ambassador in Oslo expressed similar views. ${ }^{4}$ This was very close to what the officials in the FO had been planning. The 'Hankey-plan', if successful, would also in fact have brought Sweden as a 'non-belligerent partner' indirectly into the Western defence system against the Soviet Union. The Swedish defence chiefs also hoped for a more pragmatic policy from the British side. The pro-British chief of the Swedish air forces, General Nordenskiöld put it along the lines: 'Let us be practical. What does it matter whether Sweden is or is not in the Atlantic Pact. You know perfectly well that

\footnotetext{
' Ibid.

${ }^{2}$ Hankey minute, 3.2.1949, FO 371/77400.

${ }^{3}$ Hankey minute, 22.12.1948, FO 371/77391.

${ }^{4}$ Hankey memorandum, 'Sweden and the North Atlantic Pact', 30.12.1948, FO 371/77400.
} 
when the balloon goes up the Swedes are bound to fight the Russians... The stronger we are both in the air, on the sea and on land, the better it will be for you'.

The importance of keeping the door open to Sweden was again highlighted in remarks made in the FO in early February 1949. Even if the 'Hankey plan' had been officially shelved, Sargent minuted that he still hoped the Swedes would come round to a compromise solution. ${ }^{2}$ Bateman envisaged that the British might have to return to the plan of interlocking security pacts. ${ }^{3}$ The Swedes were consequently informed that even their failure to reach a settlement with their Scandinavian neighbours did not mean that some kind of viable solution could not be found based on Swedish participation in Scandinavian defence. Hägglöf was told on 4 February, that 'as far as the future was concerned the defence of Scandinavia could still be assured on a more or less common basis provided that M. Undén would allow the Swedish Defence Chiefs to make private staff arrangements with the Norwegians and Danes' ${ }^{4}$ The British impression was that Hägglöf agreed with this. He replied that 'this was not the end of the history of Scandinavian cooperation but so far as allowing defence discussions to continue this would certainly be a matter of time'. ${ }^{5}$ In Jebb's view it would take 'a year or two' before the 'Swedes would begin to see the light' as they would be compelled to abandon their neutrality and 'make certain arrangements with the Atlantic Pact powers as well' ${ }^{6}$

As one of the less hawkish policy makers in British Scandinavian policy, Hankey was supported by the senior officials in the FO in adopting a more accommodating attitude with the Swedes. Bateman and Sargent gave their strong backing to this line. In dealing with Hägglöf in London, Bateman was also purposely subtle and tried to refrain from

\footnotetext{
${ }^{1}$ Farquhar to Hankey, 9.2.1949, FO 371/77401.

${ }^{2}$ Sargent minute, 1.2.1949, FO 371/77393.

${ }^{3}$ Bateman minute, 5.2.1949, FO 371/77393.

${ }^{4}$ Hankey minute, 4.2.1949, FO 371/77394.

${ }^{5}$ Ibid.

${ }^{6}$ Jebb minute, 11.2.1949, FO 371/77397; Jebb minute, 9.2.1949, FO 371/77398.
} 
making 'the Swedes even more pig-headed'. ${ }^{1}$ This view was not shared by Collier in Oslo, who saw Norway's participation in the Atlantic pact and Sweden's isolation as a major victory for the Western powers. That the lone opposition of Collier from Oslo may had had an impact on the FO's failure to find a compromise, was made all the more irritating by his rejoicing of the end result. Hankey in particular found it difficult to veil his disappointment in correspondence with Collier. The fact that the case was not considered closed in the FO was conveyed in clear terms to Collier, who had opposed any proposals to involve a neutral Sweden in the Western security system. As if to remind him who in the end was responsible for policy-making, Hankey wrote to Collier on 8 February to remind that it was 'obvious that we now have to think again in order to find a solution for the Scandinavian problem'. Hankey said that the view held in London was that the British should 'induce the Swedish Government to allow their General Staffs to make staff arrangements with the Norwegian and Danish Service Authorities'. ${ }^{2}$ This at least was better than the present situation.

What form of association with the Atlantic pact?

The main problem with the idea of contacts on service level and Sweden's indirect participation in the Atlantic pact, was that even if coordinated plans were made and information exchanged, any definite commitments could not be made without political approval between the governments. Collier, sceptical as usual, pointed this out from his post in Oslo, as he did not believe that service contacts were likely to lead to much so long as the political line of the Swedish government did not change. ${ }^{3}$ Officials in London

\footnotetext{
' Bateman minute, 12.1.1949, FO 371/77392.

${ }^{2}$ Hankey to Collier, 8.2.1949, FO 371/77393.

${ }^{3}$ Collier to Hankey, 20.7.1949, FO 371/77710.
} 
were somewhat more hopeful that it was equally conceivable that this kind of collaboration, besides leading to useful practical results, would also in time influence the political situation. ${ }^{1}$ Meanwhile, the actual military planning had to be done by the COS on the assumption that Sweden would remain neutral and in due course be overrun by Soviet forces. ${ }^{2}$ The COS appreciation in April 1949 about the political situation in the outbreak of war was, that Sweden with Switzerland and Spain 'would probably be initially neutral', and that Finland would be in association with the Soviet Union. ${ }^{3}$

A situation, where the publicly stated policy was not to bring any pressure to bear on the Swedes to abandon neutrality, but simultaneously to encourage the establishment of secret working relationship in strategic matters, also created potential political difficulties for the British. Farquhar in Stockholm was keen to receive instructions on how to go on in a situation, whereby not only the political integrity of the Swedish military but also of the British diplomatic and military representatives was endangered. Farquhar asked the FO to clarify whether British policy was to leave Sweden completely out or work towards an association with the North Atlantic Treaty. ${ }^{4}$ The middle course seemed difficult, and politically dangerous.

In March 1949 the British position towards Sweden was defined as 'to leave the Swedes alone in the hope that the hard facts of the situation and a growing understanding of the advantages to be derived from co-operation with the West will gradually induce a change in their present attitude'. Bevin reasserted his previous policy that no pressure should be brought to bear on the Swedes to bring about this realisation of the 'hard facts'. The British government were more aware of the possible setbacks of a forward

\footnotetext{
${ }^{\prime}$ Etherington-Smith minute, 12.8.1949, FO 371/77710.

2 'Norway - Advice on Defence', Report by the JPS, 2.3.1949, JP(49)12(Final), DEFE 4/20.

3 'Logistic Examination of Plan Speedway', Report by the JPS, 7.4.1949, JP(49)3(Final), DEFE 4/21.

${ }^{4}$ Farquhar to Hankey, 7.4.1949, FO 371/77401.

${ }^{5}$ Etherington-Smith minute, 8.3.1949, FO 371/77399.
} 
Western policy than the Americans were and had to play a careful balancing act. While a tougher US approach had delivered nothing in terms of Swden's Western connection this far, it was yet confirmed in February 1949 in a memorandum prepared by the Joint Chiefs of Staff to President Truman that the US aim was 'to influence Sweden to abandon its attitude of subjective neutrality vis-a-vis the Soviet Union and the West and to look toward eventual alignment with other Western Powers'. ${ }^{1}$ A corollary to this was that 'backdoor membership' in the Atlantic pact, giving Sweden 'essential advantages [of] membership without corresponding commitments' was ruled out in Washington in April $1949 .^{2}$ Neither did Matthews give up his vehement criticism of Sweden's neutrality policy, despite a growing realisation also in Washington of the difficulties involved in achieving the goals set out by the National Security Council. ${ }^{3}$ In May 1949 informal guidelines were drafted at the official level in the State Department, which stated that no active measures should be taken to induce Sweden to adhere in the Atlantic pact. ${ }^{4}$ But as long as Sweden's membership in the pact was the stated policy aim, the relationship between the US and Sweden would remain more detached than the Anglo-Swedish one.

An important consideration in London was that if too much pressure was used on any of the Scandinavian governments, the Soviets could more effectively and easily use their influence to counter this, and as it was feared, possibly isolate all the Scandinavian countries, including Norway, from the West. ${ }^{5}$ This attitude was in line with earlier appreciations of the nature of the situation in Scandinavia. British policy, especially in the case of Finland which was most immediately under Soviet threat, had been to try to

${ }^{1}$ National Security Council report, 'The Military Implications to the United States of a Scandinavian Pact', 3.2.1949, NSC 28/2, President Secretary's Files, Papers of Harry S. Truman. Harry S. Truman Library, Independence, Mo., copy in Vol. 13, NPCA.

${ }^{2}$ Charles E. Rogers to Matthews, 18.4.1949, copy in Vol. 19, NPCA.

${ }^{3}$ Matthews to Dean Acheson, 28.3.1950, SD, 758.00/3-2850, NA, copy in Vol. 13, NPCA.

${ }^{4}$ SD memorandum, 'Current Policy toward Sweden', 13.5.1949, NND 857560, RG 84, Box 2, NA; Hickerson to Cumming, 19.5.1949, copies in Vol. 19, NPCA.

${ }^{5}$ Hankey minute, 9.2.1949, FO 371/77400. 
keep the cold war out of the region. Frank Roberts, one of the Soviet specialists in the FO, thought that the Soviet Union had no intention of engaging in a forward policy in Scandinavia and wanted only to keep Scandinavia as far away from the Western Powers as possible. ${ }^{1}$ British actions should not reverse this trend. Later research, based on Soviet archival material for the Stalin years, has proved that this assessment was essentially correct. $^{2}$

The policy adopted in the FO in April 1949 was that 'we do not want the Swedes to apply to join the Atlantic Pact', as it would be extremely difficult to do anything to help them if war suddenly broke out. ${ }^{3}$ These views, but not those relating to a possible tacit coordination of strategic plans, were communicated to the Americans in May, who then saw the immediate goals of British policy so closely corresponding their own that special consultations on coordination of policies were thought unnecessary. ${ }^{4}$ However, the convergence of views as to whether to leave Sweden out of the Atlantic pact for the time being or to try and pull it in, was combined with important differences as well. If the British were willing to create more contacts with the Swedes across the board, on economic, political as well as military questions, the Americans still entertained hopes that a 'cultivation of doubts in the Swedish mind' and a display of the fact that no arms or military technology was available from the US, should bring Sweden closer to the West. ${ }^{5}$ But these negative measures were essentially a passive policy, whereas the British were more active. Nevertheless, the most important difference was the SD's recommendation that the US 'should not encourage overtures for common military

\footnotetext{
${ }^{1}$ Roberts minute, 11.2.1949, FO 371/77395.

${ }^{2}$ Jukka Nevakivi, Zdanov Suomessa. Miksi meitä ei neuvostoliittolaistettu (Helsinki: Otava, 1995).

${ }^{3}$ Hankey minute, 11.4.1949, FO 371/77401.

${ }^{4}$ Hickerson to Cumming, 19.5.1949, copy in Vol. 19, NPCA.

${ }^{5}$ Matthews to Llewellyn E. Thompson, 17.6.1949, copy in Vol. 19, NPCA.
} 
planning on informal levels'. ${ }^{1}$ This was precisely what the British were going to encourage.

The commitment the Western powers had entered guaranteeing Norway and Denmark against aggression spoke for the need to find some kind of solution for coordinated Scandinavian defence. Hankey wanted to maintain a low profile in the Swedish question, at least until the North Atlantic Treaty was safely ratified and enough time had gone by to enable the Swedes 'to feel uncomfortable' and for the Norwegians to realise, 'that perhaps their present situation as members of the Atlantic Pact could be improved'. ${ }^{2}$ Hankey had no wish to resurrect the controversy about the Scandinavian Defence Union. Even more important, the results of the discussions of the Atlantic Pact Defence Council, would determine what the overall Western strategy and defence plans concerning Scandinavia would be like. Evelyn Shuckburgh from the Western Department agreed with the line proposed by Hankey. In his view the inclusion of Norway and Denmark in the Atlantic pact had been a great political success in view of Soviet pressure on them not to join, 'but it did not add anything very tangible to the military security either of Scandinavia or of Western Europe'. The value of the North Atlantic Treaty was in preventing war, not in winning one. 'The addition of Sweden, even if it did strengthen the defensive position of Norway and Denmark, would not significantly alter the fact that Scandinavia and Western Europe are indefensible'. ${ }^{3}$

These more pessimistic considerations represented by Shuckburgh did not alter the policy of favouring inter-Scandinavian defence cooperation. ${ }^{4}$ Hankey instructed Farquhar that inter-Scandinavian defence arrangements were still favoured, although the British did

\footnotetext{
' SD memorandum, 'Current Policy toward Sweden', 13.5.1949.

${ }^{2}$ Hankey minute, 11.4.1949, FO 371/77401.

${ }^{3}$ Shuckburgh minute, 11.4.1949, FO 371/77401.

${ }^{4}$ Farquhar to Hankey, 14.4.1949, FO 371/77401.
} 
not want to commit themselves more than already had been done. ${ }^{1}$ For Bevin's meeting with Undén in Paris in May 1949, the Northern Department briefed him that:

It is by no means certain that we should be in favour of Sweden joining the Atlantic Pact at the present time even should the possibility present itself. On the other hand, it does seem most desirable that Sweden should sooner or later make some joint plans with Norway and Denmark for the common defence of Scandinavian in case of an attack. ... This need not, in our view, entail any formal arrangements, but could be achieved by practical cooperation between the service authorities of the three countries. ${ }^{2}$

The British policy of not favouring Sweden's early adherence to the Atlantic Pact was reiterated in autumn 1949, when it was also explicitly combined with a clear acceptance of Sweden's policy of neutrality. In June 1950, Harrison told Hägglöf that, while the British did not want to show any overt understanding for neutrality as a foundation for a Western European state's foreign policy, they nevertheless understood, that the present strategic situation in the Nordic region gave a good reason for Sweden to follow its nonaligned policy. ${ }^{3}$

\section{Steps towards coordinated Scandinavian defence}

Simultaneously, while Sweden's neutrality policy was not actively opposed, the British continued their previous policy of encouraging further inter-Scandinavian defence planning. As Falla put it in autumn 1949: '... we are anxious to encourage interScandinavian staff talks to continue as they are now, on a military rather than a political

\footnotetext{
${ }^{1}$ Hankey to Farquhar, 26.4.1949, FO 371/77401.

${ }^{2}$ Hankey minute for Bevin, 30.4.1949, FO 371/77401.

${ }^{3}$ Hägglöf to Dahlman, 17.6.1950, Hp $1 \mathrm{Ba}$, Vol. 103 .
} 
footing, so that Sweden may more easily dovetail into the Pact organisation when that crystallizes and when the advantages of open military co-operation outweigh those of political neutrality'. 1

From 1946 onwards, Scandinavian defence authorities had held discussions on different aspects of Scandinavian defence cooperation and coordination. The British had at all stages been closely involved and well informed of these developments. ${ }^{2}$ They were well aware of the central position that the Scandinavian military attached to Britain, backed by the US, as the Western power most immediately concerned with Scandinavian defence. ${ }^{3}$ Despite increasing political differences between the Scandinavians about their place in the emerging Western alliance system, talks on the coordination of defence measures between Norwegian and Swedish General Staffs continued in 1947-48. ${ }^{4}$ The British were informed that the politicians on each side knew and approved of these talks, though they turned a blind eye to them and did not support them openly. ${ }^{5}$

This had changed with the Swedish SDU initiative. It led to openly sanctioned talks between the Scandinavian General Staffs, which culminated in the work of the defence committee, set up to study the military and strategic conditions for a Scandinavian military bloc in autumn $1948 .^{6}$ The failure of these plans at the political level nevertheless led to a temporary halt of defence talks at the service level, while all sides took stock of the situation in early $1949 .{ }^{7}$ Nevertheless, Swedish military representatives

P.S. Falla to Major Willoughby (WO), 21.9.1949, FO 371/77401.

${ }^{2}$ For example, the highly confidential report of the Scandiavian defence committee was leaked by the Swedish General Staff to the British in January 1949. Farquhar to Hankey, 9.2.1949, FO 371/77401. This at least brought them on par with the Russians, who had procured their copy as well. Birgitta Bergmark, Stig Wennerström. Spionen som teg (Falun: Bonnier Alba, 1993), 36 - 41. The report was made public in Sweden in 1994.

${ }^{3}$ Farquhar to FO, 14.5.1948, FO 371/71452.

4 'Scandinavia: the present political situation', FO brief for the secretary for overseas trade, 30.3.1948, FO 371/71447.

${ }^{5}$ Collier to Hankey, 23.12.1947, FO 371/71444.

${ }^{6}$ Scandinavian defence committee's report, Försvarsdepartement, Vol. F I: 181 B.

${ }^{7}$ Farquhar memorandum, untitled, 13.4.1949, FO 371/77710. 
informed both the British and Americans that until there was any change in the official policy of the Swedish government, it was the desire and intention of the Swedish and Norwegian armies to continue coordinate defence plans independently. ${ }^{1}$ The Swedish military authorities also hinted that their government might not be actively opposed to more or less secret staff talks with the Norwegians. ${ }^{2}$

After Norway and Denmark joined the North Atlantic Treaty, the actual meaning of the pact became acute. True enough, the Americans had taken the unprecedented step to offer a security guarantee to Norway and Denmark, a step that had been as unprecedented to Britain as well. But as long as this guarantee was on paper only, any countries located geographically as close to the Soviet Union or its satellites as the Scandinavians were, would have a sense of insecurity attached to the advisability of having joined the 'Atlantic community'. Nonetheless, neither the Norwegians nor the Danes entertained false impressions of massive military aid from the West if war broke out in the near future, although it still came as a shock, especially to the Danes, when the full extent of the Western powers' inability to defend them became clearer in $1950 .{ }^{3}$ Their main motivation to join the pact was long term. It provided them with an overall security umbrella and with prospects of building their own defences with Western financial and material aid. But in the immediate future, only a limited amount of armed support from the West could be expected in a crisis, mainly from the British navy to secure lines of communication over the North Sea. ${ }^{4}$ For immediate security they had to

\footnotetext{
${ }^{1}$ Collier telegram No. 53 to FO, 1.2.1949, FO 371/77400.

${ }^{2}$ Farquhar memorandum, untitled, 13.4.1949, FO 371/77710.

${ }^{3}$ Berdal, The United States, Norway and the Cold War, 4 - 9, 22 - 23; Villaume, Allieret med forbehold, 124 - 129, 144 - 151.

4 'Anglo-American Strategy and Deployment of Forces in 1951', Report by the JPS, 26.7.1949, JP(49)73(Final), DEFE 4/23. These problems persisted, although the British led NATO's northern command was a strong advocate of the defence of the northern flank. Notes by Admiral Patrick Brind on North European Command, 20.4.1953, Brind papers, Liddell Hart Centre for Military Archives, Kings College, London.
} 
turn, whether they liked it or not, to their stronger eastern neighbour. Sweden's main problem was that after Norway and Denmark joined the Atlantic pact, their own defence plans had to be recast. The first difficulty was the lack of knowledge of Atlantic pact planning concerning Scandinavia.

Informal channels of communication were nonetheless rapidly opened between the British and the Swedish service authorities. In March 1949 the commander in chief of the Swedish navy, Admiral Helge Strömbäck explained Swedish strategic thinking to the British naval attaché, Captain Derek Wyburd, in Stockholm. Strömbäck felt that Sweden might be involved in war under two different circumstances: Either after a Russian attack on Finland without a general war involving the Western powers, or in case of an attack on Denmark and South Norway which would inevitably involve Sweden. He did not expect any help from the Atlantic pact countries in the first scenario, but in the second, he said that 'the Western Powers would already be at war and would therefore be the allies of Sweden'. ${ }^{1}$ His remarks did not leave much room for a possible Swedish neutrality in war.

The admiral stressed the need for receiving information about Western war plans in northern Europe, but Wyburd had to rebuff him by saying that 'there was not the slightest chance of us disclosing any plans that we might have made to a power outside the Atlantic Pact'. ${ }^{2}$ If any wideranging disclosure of planning information was not possible at the moment, the British naval attaché suggested that they should prepare common sea/air recognition signals and cyphers ready for use in the event of Sweden becoming Britain's ally in war. Strömbäck agreed with this, but added that this would have to be done without the knowledge of the minister of defence. ${ }^{3} \mathrm{~A}$ reciprocal flow of intelligence information about the Soviet Union was suggested and agreed. Strömbäck

\footnotetext{
${ }^{1}$ Naval attaché to director of naval intelligence (DNI), 22.3.1949, FO 371/77728.

${ }^{2}$ Ibid.

${ }^{3}$ Ibid.
} 
said he would talk to the relevant organisation in Sweden.

In the FO, the first reaction to the Swedish suggestion for an exchange of military plans was non-committal. Without clear instructions from their political masters, junior officials saw 'no future in Anglo-Swedish planning' and minuted cynically that it was likely that in the context of the Atlantic pact, both the Americans and the British would leave the defence of Scandinavia largely to the Norwegians and Danes themselves. ${ }^{1}$ Despite these difficulties, British help to the Swedes in planning would be consistent with their policy of keeping Sweden as strong as possible, of which a relatively relaxed arms exports policy was an important part. But the fact that this would have to be done behind the back of the Swedish government was considered a serious drawback. Nevertheless, even 'an exchange of information on a very restricted scale would be of great advantage'. ${ }^{2}$ Indicating the more optimistic atmosphere at the more senior official level, also Hankey shared this view of the value of exchange of intelligence information, but any more widereaching planning cooperation was precluded because of the current policy of the Swedish government. ${ }^{3}$

In the meanwhile, from the British point of view, it was very important that the talks between the Scandinavian general staffs would continue as soon as possible. ${ }^{4}$ Finally, in April 1949, the Swedish Defence Minister, Allan Vougt, gave verbal approval to Admiral Strömbäck to continue defence discussions with his Norwegian and Danish counterparts. ${ }^{5}$ One of the most immediate questions affecting British strategy was the question of the Baltic exits - or entries, depending on the viewpoint - especially the narrow passage between Denmark and Sweden which could be defended only if those

${ }^{1}$ A. R. H. Kellas minute, 26.4.1949; E. M. Rose minute, 27.4.1949, FO 371/77728.

${ }^{2}$ L. C. W. Figg minute, 20.4.1949, FO 371/77728.

${ }^{3}$ Hankey to Rear-Admiral E. W. L. Longley-Cook (ADM), 16.5.1949, FO 371/77728.

${ }^{4}$ On 'partial' Scandinavian defence cooperation, Had there been a war..., 137 - 147.

${ }^{5}$ Naval attaché to DNI, 'Sweden and cooperation in Scandinavian defence', 5.7.1949, FO $371 / 77710$. 
countries combined their forces and kept close contact between the planners of defence on both sides of the Sound. ${ }^{1}$ As the bulk of the Soviet navy was based in the Baltic Sea, the British navy considered it very important to be able to prevent it from entering the North Sea and Atlantic in time of crisis, where its presence would force the Western allies into a defensive position.

That some progress was being made on this issue, was confirmed by Admiral Strömbäck, who told the British naval attaché in May 1949, that 'he intended to go ahead with the making of naval plans with Denmark', provided his colleagues across the Sound were willing to do so. ${ }^{2}$ The Danes already had the old Swedish plans for mining the Sound, but these plans were under revision during the summer of $1949 .{ }^{3}$ Similar talks were proposed to the Norwegian navy as well. During summer 1949 a plan for joint defence of the Sound between the Swedish and Danish navies was completed, but after that no further progress was made. Some direct cooperation with the Swedish and Norwegian navies concerning a common ship reporting organisation to cover the Skaggerak and northern Kattegat was also reported to London. ${ }^{4}$ Another issue besides the defence of the Sound was the defence of Zealand. Strömbäck told the British that preliminary talks about the evacuation of civilian populations from the metropolitan area to southern Sweden in war had already taken place. ${ }^{5}$

On the issue of keeping the British informed, Strömbäck made it clear, that even if the government policy was to treat the foreign service attachés on equal footing, he had 'no secrets from the British' and it was up to the British naval attaché 'to find those officers who are prepared to give him what he wants to know and I shall have no

\footnotetext{
' Randall to Bevin, 30.3.1949, FO 371/77396.

${ }^{2}$ Naval attaché to DNI, 28.4.1949, FO 371/77401.

${ }^{3}$ Naval attaché to DNI, 'Sweden and cooperation in Scandinavian defence', 5.7.1949, FO $371 / 77710$.

${ }^{4}$ Annual report for 1949 on the Royal Swedish Navy, 26.1.1950, FO 371/86952.

${ }^{5}$ Naval attaché to DNI, 28.4.1949, FO 371/77401.
} 
objection'. ${ }^{1}$ During summer 1949 a number of British naval visits to Swedish ports were also made. This was, again, in contrast with the Americans, who had specifically left Sweden out from their visits to Danish and Norwegian ports as a sign of political disappointment of Sweden's recent behaviour. ${ }^{2}$ As Derek Wyburd, the naval attaché in Stockholm said, this together with the fact that the US navy refused to take any part in the modernising of the Swedish navy, caused many Swedish naval officers 'to look rather coldly on the Americans' ${ }^{3}$

Besides naval matters the British were also interested in Scandinavian air defences. Here also, it seemed that steady progress could be made. In May 1949 General Nordenskiöld said that there was an agreement between them and the Norwegians about the best layout of radar chains covering the region and about freedom of overflights. The Danes, having no effective air force, was nevertheless kept fully in the picture and the Swedes had promised to lend them some Vampire aircraft to help to build up their air force quickly. ${ }^{4}$

Perhaps the most promising aspect was the attitude of the Swedish air force. In conversations with the British, Nordenskiöld expressed his view that 'although Sweden is not actually signatory power she is to all intents and purposes a member of the Atlantic Pact'. Before the Swedish government would come around to accept this also publicly, Nordenskiöld suggested that 'the members of the Pact would prefer to have Sweden in her present position of being virtually a member without actually having signed' .5 From utterances like this, the British concluded that the Swedes were at pains to demonstrate to the Western powers that their country was strategically so important that it could not

\footnotetext{
${ }^{1}$ Annual report for 1949 on the Royal Swedish Navy, 26.1.1950, FO 371/86952.

${ }^{2}$ Ibid.

${ }^{3}$ Tbid.

${ }^{4}$ Air attaché M. Wyatt's report, 9.5.1949, FO 371/77415.

${ }^{5}$ Ibid.
} 
be left out of Western military planning and that it was well able to take care of its sector of the northern front, if it was properly equipped and assisted. ${ }^{1}$ In this they might have exaggerated both their military potential and its usefulness to the West.

The situation concerning inter-Scandinavian cooperation was also discussed by the COS in May 1949, when they agreed that closer consultation between Norway and Sweden in defence matters was very desirable and 'entirely in line with the views expressed by the Chiefs of Staff in the past'. ${ }^{2}$ The COS thought that this was the best way to link Sweden to the Atlantic pact. The problem was how to fit this cooperation within the general North Atlantic Treaty framework. In this respect the question of passing NAT information to the Swedes had to be considered carefully, although the British considered Swedish security very good. They already had 'pretty good contacts with the Swedish intelligence service', and the Swedish air raid reporting system was considered to be a distinct asset to the British. ${ }^{3}$

The considerations of both the FO and the COS, was thus strongly in favour of encouraging inter-Scandinavian defence cooperation and a degree of information exchanges. The Norwegian Defence Minister Jens Christian Hauge, was subsequently informed that he could automatically pass all Atlantic pact planning information concerning Scandinavia to the Swedes, and other Atlantic pact information or intelligence if not graded higher than confidential. ${ }^{4}$ Other cases would have to be considered separately. It was also agreed by the COS and FO to pass the Swedes other intelligence information about the Soviet Union originating from British sources. This decision was made in the belief that the Swedes also possessed useful intelligence about the Soviet

\footnotetext{
${ }^{1}$ Farquhar to Attlee, 13.4.1949, FO 371/77728.

${ }^{2}$ COS minutes, 16.5.1949, COS(49)72, DEFE 4/21.

${ }^{3}$ Ibid.

${ }^{4}$ Ibid.
} 
Union, which the British would receive in return. ${ }^{1}$

A serious problem in coordinating Swedish defence plans with the Atlantic pact, was that the plans of the pact were still in 1949 on the drawing board. The Swedish pointed out the difficulties caused by this lack of information about Western plans, but they assured the British that whatever the policy of the Swedish government, they would like to link the Swedish plans with those of the Atlantic pact. ${ }^{2}$ The British military representatives, without clear political authorisation from their government, still had to stay noncommittal about passing Western military plans to the Swedes. But the indications were, that on their side, the Swedish armed forces would welcome some form of cooperation with the British and the Atlantic pact countries, and might be prepared to 'make plans with us without the official approvement of their Government'. ${ }^{3}$ But as Farquhar wrote in July, to enter this kind of direct arrangement with the Swedes, had to be cleared at the highest political level in Britain. ${ }^{4} \mathrm{~A}$ decision to enter some form of secret military cooperation with the Swedes would also include the delicate question of what would the British actually do for the Swedes if war broke out.

In August 1949, the British embassy in Stockholm was able to draw some conclusions about the extent and prospects of Scandinavian defence cooperation. Staff contacts had been and were going on with the Danes and Norwegians 'on small scale'. Good progress had been made over the defence of the Sound, and on air issues with the Norwegians. But the position concerning the armies was less promising. The worst handicap of any cooperation was that the Swedish government had given no definite instructions. There was only a tacit understanding that talks with the Danes and Norwegians 'may be

\footnotetext{
${ }^{1}$ Hankey minute, 28.5.1949, FO 371/77415.

${ }^{2}$ Naval attaché to DNI, 'Sweden and cooperation in Scandinavian defence', 5.7.1949, FO 371/77710.

${ }^{3}$ Ibid.

${ }^{4}$ Farquhar to Hankey, 7.7.1949, FO $371 / 77710$.
} 
undertaken provided the Government is not implicated' .'

In the COS, the inter-Scandinavian talks that had taken place after the abandonment of the Scandinavian Defence Union, had led to increasing optimism about finding a solution to the Scandinavian defence problem. It saw the Swedish attitude towards Scandinavian defence arrangements promising, as it assumed in September 1949, that 'Sweden would be aligned alongside Norway and Denmark', if the Russians invaded the region. ${ }^{2}$ As the command organisation of the Northern European Regional Group of the Atlantic pact was outlined at the time, the JPS suggested that the command organisation for war in Scandinavia should also allow for Swedish participation. ${ }^{3}$ Nevertheless, Swedish formal participation with any part of the Atlantic pact organisation was not advisable as it had not joined the treaty. 'Informal association of Sweden with this region' was, however, highly desirable. ${ }^{4}$ Following policy laid down by the COS, by late 1949 Sweden was fully included in the war plans of the Northern European Regional Group. The reason behind this was the attitude displayed by the Swedish military circles. The JPS wrote in November 1949 that 'since the defence of Scandinavia can only be planned effectively in conjunction with Sweden, we have included this country in the area of this Group, although Sweden is not a signatory of the North Atlantic Treaty'. 5 To this end, inter-Scandinavian defence talks should be encouraged and continued, but outside the aegis of the Atlantic Treaty Organisation. ${ }^{6}$

The task of the Swedish military and other critics of the policy of neutrality was

${ }^{1}$ Lambert to Hankey, 18.8.1949, FO 371/77708.

2 'Command organisation for war in 1951', Report by the JPS, 5.9.1949, DEFE 4/24.

${ }^{3}$ Ibid.

4 'Directive to the Northern European Regional Chiefs of Staff Committee', Report by the JPS, 17.10.1949, DEFE 4/25.

5 'Division of responsibility for planning between Atlantic Treaty Regions', Report by the JPS, 2.11.1949, DEFE 4/26.

${ }^{6}$ 'Subordinate commande arrangements - Southern European and Northern European Regional Groups', Report by the JPS, 28.10.1949, DEFE 4/26. 
politically very sensitive. In late 1949 and early 1950 the dispute between the Swedish military and the social democrat government about Sweden's defence policy became public. As the military chiefs gave highly critical speeches about Sweden's neutrality and spoke openly for the need to make defence arrangements with Norway and Denmark, the government entrenched itself even more firmly into its previous positions. ${ }^{1}$ The talks between the Swedish Defence Staff and their Norwegian and Danish counterparts were temporarily suspended in early 1950. The British believed that the government was behind this, as the Swedish foreign minister came out flatly against even technical cooperation with Norway and Denmark in March $1950 .^{2}$

The mood in Norway and Denmark also became cooler towards the Atlantic pact, as it dawned to them that they were not going to receive much assistance either from Britain or from the US. The cost to both countries of strengthening their defences as required by the pact was also realised. The British also saw a growing tendency in Norway and Denmark to turn their thoughts once again towards Sweden and to consider whether defence cooperation based on common Scandinavian neutrality might be possible. ${ }^{3}$ On the positive side, besides the inter-Scandinavian military discussions that had taken place in 1949, the British saw firm signs among the Swedish service chiefs that they thought military collaboration with the West was necessary. As a sign of this attitude, a meeting was proposed between British and Swedish admirals on naval matters. ${ }^{4}$ The information about the strategic thinking of the Swedish armed forces was also hopeful, as obviously they considered the Soviet Union as the only possible enemy and thought that Sweden would not be able to maintain its neutrality when war broke out. ${ }^{5}$

\footnotetext{
' Lambert to McNeil, 2.2.1950, FO 371/86947.

${ }^{2}$ Etherington-Smith minute, 11.4.1950, FO 371/86167.

${ }^{3}$ Ibid.

${ }^{4}$ Ibid.

${ }^{5}$ Lambert to McNeil [sic], 2.3.1950, FO 371/86947.
} 
British hopes of influencing Sweden into the right direction were pinned upon the maintenance and development of service contacts, with or without ministerial approval, and to the increasing number of public statements pointing out the advantages of interScandinavian cooperation. It could be that Swedish opinion was at least 'beginning to develop a more realistic approach to the whole problem', and there appeared to be a 'newly awakened desire to find a solution which would enable Sweden to make essential plans with Norway and Denmark, while preserving her formal neutrality'. ${ }^{1}$

Besides talks with the other Scandinavian naval authorities, the Swedish Naval Staff initiated a series of talks with the British about direct Anglo-Swedish naval cooperation. The talks were held in Stockholm between the British naval attaché and Admirals Strömbäck and Anderberg to prepare plans to cover for possible cooperation in war, 'both of Sweden being neutral and an ally'. ${ }^{2}$ Strömbäck and Anderberg stressed the need for complete secrecy, for otherwise 'the Ministers would be furious if they knew that this subject was being discussed now'. ${ }^{3}$ The Swedish admirals suggested that cooperation should be divided into two stages, first to cover the threat of war or war with Sweden being neutral, and secondly to cover war in which Sweden was taking part. Regarding the first stage the extent of cooperation would depend on the political situation, but the Swedish admirals assured that the British could rely on closer contact with the Swedish Naval Staff, in particular concerning intelligence, and on close cooperation at the Gothenburgh area. Also an British liaison officer should be made available at the naval base in Karlskrona. In stage two, the political difficulties would have been removed and a British naval mission should be attached to the Swedish Naval Staff with liaison at Gothenburg to assist with convoys, and Karlskrona in case communications between

\footnotetext{
${ }^{1}$ Etherington-Smith minute, 11.4.1950, FO 371/86167.

${ }^{2}$ Naval attaché to DNI, 29.10.1949, FO 371/86952.

${ }^{3}$ Ibid.
} 
North and South were disrupted. ${ }^{1}$

The FO was fully aware of the political problems this kind of cooperation at service level entailed. Nevertheless, because the Admiralty confirmed that they attached great importance to it for military reasons, it was agreed first on official level that the Admiralty should proceed in their plans and hope that the Swedish government would not learn about them. ${ }^{2}$ The need for secrecy also spoke against informing the Danish and Norwegian authorities, and apprehensive about the consequences of a possible leak, Jebb suggested that they should not yet be informed. ${ }^{3}$ In the end this was decided to be done orally and privately through the Northern European Regional Planning Group of the Atlantic pact.

With Northern Department's approval, the Admiralty authorised the naval attaché in Stockholm on 1 February to proceed with these discussions and detailed plans of the composition of these missions were made. ${ }^{4}$ British mobilisation plans were amended to allow for additional staffs to go to Sweden in these contingencies. ${ }^{5}$ Technical discussions were authorised by the Admiralty on the question of communications between the Admiralty and the Swedish Naval Staff, Karlskrona Naval Headquarters and Gothenburg Naval Headquarters. So as to avoid any attention being drawn to the talks, it was decided that they should take place in secret and informally during British naval visits to Sweden in summer $1950 .{ }^{6}$ No commitments on the behalf of the British government should be made at this stage. It was also decided that the conversations should be conducted 'with the fewest possible interlocutors', and that nothing from the British side should be

\footnotetext{
${ }^{1}$ Ibid.

${ }^{2}$ Harrison minute, 18.2.1950; Harrison brief to the secretary of state, 18.2.1950, FO $371 / 86952$.

${ }^{3}$ Jebb minute, 18.2.1950, FO 371/86952.

${ }^{4}$ DNI to naval attache, 1.2.1950, FO 371/86952.

${ }^{5}$ Naval attaché to DNI, 29.10.1949, FO 371/86952.

${ }^{6}$ DNI to naval attache, 1.2.1950, FO 371/86952.
} 
communicated to the Swedes in writing. ${ }^{1}$

After being informed of these talks, Bevin considered the political aspect so delicate that before completing any definite plans, he had to have the approval of the prime minister and the minister of defence. Bevin also shared Jebb's view that the danger of a possible leak if the Norwegians and Danes were informed was too great. Nevertheless, as it was agreed that the talks with the Swedes would be informal and discreet, no documents from the British side would be presented and the only specific question would be communications, Bevin gave his approval to go ahead in early March 1950 and did not formally seek the approval either of the prime minister or the minister of defence at this stage. ${ }^{2}$ In April 1950 the naval attaché was given the final clearance to contact the Swedish naval authorities to arrange for the discussions during the oncoming naval visits.

The talks were held in Sweden on 17 June 1950 between Admiral Strömbäck and Rear-Admiral Slayter. Slayter made it clear from the beginning that the British would not engage in any surface operations in the Baltic Sea, and the support to Sweden in that theatre would be confined to bombing and air-mining operations. In the west, the Swedish merchant navy would be escorted to Norwegian territorial waters by the British navy. ${ }^{3}$ Strömbäck in his turn gave Slayter a comprehensive outline of Swedish naval war plans and the dispositions of their forces. The main questions he had, concerned the British contribution in the defence of the Sound and other British air-mining plans. As the Danes had joined the Atlantic pact and the first joint plans to block the Sound were completed in summer 1949, no further progress had been made with the Danes. In order

\footnotetext{
${ }^{1}$ Abercombe (ADM) to Harrison, 4.3.1950; draft instructions to the commander in chief of the Home Fleet, undated, FO 371/86952.

${ }^{2}$ Harrison memorandum, 'Naval Talks with Sweden', 9.3.1950; Bevin minute, undated, FO $371 / 86952$.

${ }^{3}$ The Flag Officer Commanding Second Cruiser Squadron, H.M.S. Superb (Slayter) to the commander in chief, Home Fleet, 'Conversations with Swedish Naval Staff', 24.6.1950, FO $371 / 86952$.
} 
to restart the talks, Slayter suggested that the commander in chief of the Home Fleet should instruct Admiral Vedel to continue collaboration in spite of the Atlantic pact. ${ }^{1}$

While it was recognised that at the start of a war Anglo-Swedish operational cooperation at sea would be unlikely, nevertheless this would be necessary later. Therefore Strömbäck suggested that intercommunication arrangements at sea should be included in the overall communications plan. The British Fleet Signal Book and other manuals, additional flags and visual, voice and wireless callsigns should be supplied. It was emphasised that all these plans should be drawn up immediately and that a codeword be introduced to bring the plan into force in the event or threat of war. ${ }^{2}$

Simultaneously with the talks on the naval side, also cooperation in air matters was initiated. From late 1949 and during 1950 a series of talks were held between the British and the Swedish civil aviation authorities about the possible transfer of the SAS (Scandinavian Air Services) aircraft to Britain in war. The Air Ministry tried through unofficial talks with Swedish officials to reach a firm understanding about the move of 'as large a part as possible of the Scandinavian Air Services Organisation to the United Kingdom in war'. ${ }^{3}$ The initiative came from the Swedes, but the talks, however, were inconclusive and only cooperation concerning communications and meteorological details could be planned. ${ }^{4}$ The FO view was that the talks should be limited to confidential technical discussions as it was by developing this line 'that we are most likely to get hold of the Swedish aircraft in the event of war' ${ }^{5}$ Even if the scope of the talks was limited,

${ }^{1}$ Ibid.

2 Ibid. In 1951 the naval missions in London and Washington were supplied with comprehensive map material of Sweden and the surrounding areas for wartime use. T. Lundberg to naval attaché in London, 14.2.1951, Marinattachén i London. Serie E I, Vol. 5, inkommande skrivelser 1951-53, Krigsarkivet, Stockholm.

${ }^{3}$ COS minutes, 17.11.1950, COS(50)181, DEFE 4/37.

${ }^{4}$ Air attaché to assistant chief of air intelligence, 3.1.1950, FO 371/86956; T. C. G. James (AIR) to Banister (Ministry of Civil Aviation), 10.6.1950, FO 371/86956.

${ }^{5}$ J. E. Powell-Jones minute, 16.1.1950, FO 371/86956. 
Etherington-Smith minuted that 'we have everything to gain from drawing the Swedes into effective co-operation with us in preparing joint wartime plans of any nature'. ${ }^{1}$ The British line was to organise the question on the 'non-political plane' so as the avoid any implications arising from the neutrality policy of the Swedish government. ${ }^{2}$ The method of the agreement, as advised by the FO, should not be made at governmental level, but that there should be 'an informal understanding', with agreed technical details of implementation. It was left to the Swedes to contemplate whether this kind of cooperation would be considered an unneutral act. The most important thing, nevertheless, was that the Swedish air fleet would be transferred to Britain in a crisis. ${ }^{3}$ Despite the absence of binding agreements, the British were left in no doubt about what the Swedish aviation authorities would prefer to do in an emergency and plans were made in Britain to facilitate the SAS fleet's transfer to UK in war. The actual implementation of these plans, as there are no traces to be found of politically binding agreements, was apparently left for consideration when an emergency arose.

To understand the significance of these tentative talks between the British and Swedish service representatives, they have to be set against the persisting difficulty in turning US policy to more positive lines towards Sweden. While the British had no qualms in confidential consultations with the Swedes, the Americans, including their military experts, were still at the time of the outbreak of the Korean war apprehensive about entering this type of confidential relations with a neutral country such as Sweden. In an informal meeting between the future ambassador to Sweden William W. Butterworth and the Joint Strategic Survey Group, consisting of military planners, the latter expressed their view that 'they would not be inclined to make quiet military arrangements with the Swedes, should the Swedes indicate a desire to cooperate with the NAT but not wish, for

\footnotetext{
${ }^{1}$ Etherington-Smith minute, 18.1.1950, FO 371/86956.

${ }^{2}$ Harrison to Air Vice-Marshal G. H. Mills, 8.1.1951, FO 371/86956.

3 James to Powell-Jones, 20.1.1950; a draft letter to air attaché, undated, FO 371/86956.
} 
the time being, to join it'. ${ }^{1}$ That the British were willing to do so, provided the Swedes with potential access to the core of Atlantic pact planning. This, together with arms exports, made British policy of particular significance to Sweden.

British arms exports policy towards Sweden

If the encouragement of the exchanges on the service level represented one half of British preparations for a war involving Scandinavia, then the other consisted of strengthening Sweden's military potential. Besides strategic concerns, this aspect of British policy contained distinctive commercial advantages.

The American attitude towards arms exports to Sweden had hardened considerably during the process leading to the North Atlantic Treaty. After the Vandenberg Resolution had been passed in the U.S. Congress in summer 1948, US policy towards armaments exports to neutral countries became stricter, thus potentially leaving Sweden without vital modern arms technology and material. In November and December 1948 the American ambassador in Stockholm used this lever to put pressure on Sweden. Matthews made it clear that Sweden could not expect any armaments from the US unless it joined the Atlantic Pact. ${ }^{2}$ In late 1948 and early 1949 the US government made it clear that a neutral Scandinavian bloc would not qualify for American material assistance. ${ }^{3}$

While the Americans seemed to fail to appreciate the value of strengthening Sweden with Western arms, the British continued to be more forthcoming. During the SDU deliberations, the British did not share the American insistence that such a bloc should

\footnotetext{
' Butterworth memorandum, 18.8.1950, SD, 758.5/8-1850, NA, copy in Vol. 13, NPCA.

${ }^{2}$ Bateman, 10.1.1949, Report of conversation with Hägglöf, FO 371/77391.

${ }^{3}$ Lundestad, America, Scandinavia, and the Cold War, 315 - 316.
} 
be cut off from Western arms supplies. ${ }^{1}$ But even for them, during the most intensive period of negotiations leading to the Atlantic pact, Swedish neutrality was difficult to swallow. As Bateman put it to Ambassador Hägglöf: 'While we understood Swedish policy in this matter, this did not mean that we agreed with it'.

Nevertheless, the fact that the British found Swedish neutrality annoying did not lead to a similar rejection as was the case with the Americans. If the American cure for Swedish isolationism was isolationism, the British preferred to keep the channels open. On the practical level British policy was most important on the field of armaments exports, as for political reasons contacts had to be restricted to staff talks below the politically binding level and limited exchange of planning and intelligence information.

Sweden's military potential was based partly on arms exports from the West, especially radar and the latest types of aircraft, but also on its own relatively advanced armaments production. The most important were the Bofors factories, which were considered the flagship of Swedish armaments industry. ${ }^{3}$ The British policy of continuing arms exports to Sweden, subject only to availability, was confirmed by the COS in January 1949 , in spite of pressure from the Americans not to do so. ${ }^{4}$ The FO had been apprehensive of the potential dangers of having a different policy from the Americans. Also the British ambassador in Stockholm suggested, that as the Swedish military were trying to put pressure on their government by saying that without Swedish membership in the Atlantic pact, military deliveries would cease, British policy should be changed to strengthen their hand. Without a change in Britain's arms export policy, 'our friends are made to look fools and $M$. Undén \& Company can almost adopt the attitude of Hitler to

\footnotetext{
${ }^{1}$ Farquhar to Bevin, 3.2.1949 (note in the marginal), FO $371 / 77710$.

2 Bateman, 10.1.1949, Report of conversation with Hägglöf, FO 371/77391.

3 Watson (Joint Intelligence Bureau, Ministry of Defence) to Hankey, 20.1.1949, FO $371 / 77729$.

${ }^{4}$ COS minutes, 7.1.1949, COS(49)3, DEFE 4/19.
} 
his Generals'.

The reasons given by the COS for their decision were fourfold. First, the British had been mainly responsible for building up the Swedish air force and variations in the supply policy would undo much of the work already done. Second, the main items to be supplied were radar equipment and some obsolent types of aircraft. The cancellation of the radar equipment would have adverse effects in Britain's own radar production programme. Besides strategic advantages, continuance of the existing policy contained definite economic benefits. More than half of the export demand for British radar sets, a good example of the latest military high technology of the time, came from neutral countries. It is clear that the orders from neutral countries played a large part in the viability of maintaining British production on this field. ${ }^{2}$ Third, a complete stoppage of supplies was feared would influence the Swedes to turn elsewhere, possibly to the Soviet Union, for the equipment they required. Fourth, the possibility that a neutral Sweden would use UK equipment against the West in war was considered remote. ${ }^{3}$ For all these military and economic advantages, the COS advised that Britain should continue its policy 'to make Sweden strong enough to maintain her neutrality or to defend herself against a Russian attack'. ${ }^{4}$ The FO accepted the decision of the COS as basis for policy. ${ }^{5}$

The political problems of having a different policy to the Americans were most evident in the work of the British embassies in Washington and Stockholm. Farquhar said that the sensitivity of this issue made his efforts to execute Britain's policy in a bipartisan manner with the Americans difficult. It was enough for the American embassy 'to get the faintest whiff of a contract, etc., for them all to get alerted and for Doc

\footnotetext{
${ }^{1}$ Farquhar to Hankey, 13.1.1949, FO 371/77400.

${ }^{2}$ Ministry of Supply statistics, 'Foreign and Dominion Government Orders on B.T.H. CO. Ltd, October 1949'; Lt.Col. P. J. Dixon (War Office) to Hankey, 18.10.1949, FO 371/77727.

${ }^{3}$ COS to FO, 10.1.1949, DEFE 4/19.

${ }^{4}$ COS minutes, 7.1.1949, COS(49)3, DEFE 4/19.

${ }^{5}$ Hankey minute 25.1.1949; Bateman minute 26.1.1949, FO 371/77729.
} 
Matthews to ask me searching questions'. ${ }^{1}$ Also the Washington embassy expressed similar concerns about American suspicions that the British were doing something behind their backs. ${ }^{2}$ Both embassies in Washington and Stockholm stressed the need to have adequate machinery to keep the Americans informed about new contracts with the Swedes, so as to minimise suspicions. ${ }^{3}$ The FO line was, nevertheless, that there was no need to inform the Americans about 'every single contract', and it was considered sufficient if the Americans were satisfied that the British were not supplying the Swedes with any material which was required by Atlantic pact countries. ${ }^{4}$

The matter was raised again in November 1949, when the Swedes placed an order for 60 more de Havilland Vampire jet airframes to follow on the previous contract for 280 . The loophole the British used to make the deal acceptable was that the Swedes were buying only the airframes, and fitting them with their own engines and weaponsystems, manufactured under British licence in Sweden. Therefore, the deal did not violate in principle with Atlantic pact requirements, even if the absence for orders from other Atlantic pact countries was more due to lack of funds than actual defence needs. ${ }^{5} \mathrm{~A}$ consensus was rapidly reached in London that 'there is no need to tell the Americans about the sale of Vampire airframes to Sweden' 6 This highlighted the strong feeling held in Britain, that ultimately only they themselves should be in charge of arms exports policy, if it did not explicitly violate agreements with the US.

In February 1949, the FO endorsed the COS views about the continuance of arms deliveries to Sweden and Bevin made clear that he was not in favour of any change of

\footnotetext{
${ }^{1}$ Farquhar to Bateman, 24.2.1949, FO 371/77394.

${ }^{2}$ Allen (Washington) to Hankey, 16.2.1949, FO 371/77726.

3 Allen to Hankey, 16.2.1949, FO 371/77726; Farquhar to Bateman, 3.3.1949, FO 371/77726.

${ }^{4}$ Etherington-Smith minute, 16.3.1949, FO 371/77726.

${ }^{5} \mathrm{~W}$. Hilton-Young minute, 17.7.1950, FO 371/86948.

${ }^{6}$ Whitwell minute, 10.7.1950, FO 371/86948.
} 
policy. In December 1948, he said that the general policy in governing the delivery of arms to Sweden should be based on availability and priority, and that Sweden would not be precluded from obtaining arms in any grounds of principle. ${ }^{1}$ In elaborating the issue further, Hankey said that any pressure the British would be able to create on the Swedish government would not be as effective as possible Russian pressure. And as Britain did not want to weaken Sweden, the effect of any change in policy would merely be counterproductive. This did not change the situation, that with the Atlantic pact, the priorities of deliveries of arms in short supply or great demand were reconsidered, but this primarily affected arms from the US more than from Britain. ${ }^{2}$ Farquhar was instructed that the current policy was not to reduce or deny supplies of arms to Sweden, 'unless they could be better used elsewhere'. ${ }^{3}$ In his conversation with Undén, Farquhar said that if there were any problems in meeting the scheduled deliveries, they would be of technical nature, and not a sign of a changed policy. ${ }^{4}$

The Swedes were well aware that the best chance of receiving the military equipment they most needed, was from Britain. The British avoided admitting this explicitly, and said instead to the Swedes that this was primarily a question of priorities of delivering arms in short supply. They said that they could not avoid giving preference to the powers who cooperated with the British in the Atlantic pact. ${ }^{5}$ But as the Swedes well knew, the key products they needed from Britain were not in this category at the moment.

Even if British policy was in 1949 firmly defined to sell Sweden the arms it wanted, provided that other Atlantic pact countries were not bidding for the same material, problems of fulfilling these requirements became more pressing in 1949 and 1950. When

\footnotetext{
${ }^{1}$ Etherington-Smith to Bateman, 19.2.1949, FO 371/77726.

${ }^{2}$ Hankey minute, 9.2.1949, FO 371/77400.

${ }^{3}$ Etherington-Smith to Farquhar, 21.2.1949, FO 371/77401.

${ }^{4}$ Undén promemoria, 26.3.1949, Hp $1 \mathrm{Ba}$, Vol. 96.

${ }^{5}$ Hankey minute, 2.2.1949, FO 371/77400.
} 
confronted with conflicting requirements both home and abroad, the bureaucratic infighting in Britain revealed some of the problems and pressures in Britain's policy towards Sweden. The conflict within the administrative structure, mainly between the Ministry of Supply, Ministry of Defence and the FO, was heightened when first practical problems in arms exports to Sweden appeared in 1949 and 1950.

The first problems appeared in radar deliveries late in 1949. The Swedish had placed a relatively large order for radar sets in 1947 , which had been considered crucial for the continuance of radar production in Britain, and had been strongly encouraged by the British authorities. The first sets were delivered in May 1948, but since then the deliveries were delayed due to increasing demand for radars from the War Office and finally in September 1949, the Ministry of Supply decided that no radar sets would be available until 1950. This led to an immediate diplomatic démarche from the Swedes, on the basis that this constituted a breach of contract. ${ }^{1}$ The FO recommended that the War Office, Ministry of Supply and Ministry of Defence should revise their position and requested that the Swedish demands should be met. This was based on both Bevin's and the COS's earlier decisions, to Sweden's 'quite satisfactory' attitude towards to the Western powers and to the adverse political effects a failure to fulfill existing contracts with the Swedes would cause. ${ }^{2}$ The FO was also apprehensive about the prospects of winning another contract. The Swedes had been sounding out the Americans about the possibility of buying American radars despite their previously critical attitude. This had, ironically enough for the British armaments industry, also been encouraged by the FO in order to meet the pressing requirements of Scandinavian defence. ${ }^{3}$ Now Bevin took the line that existing contracts had to be fulfilled, especially as the British needed the

\footnotetext{
${ }^{1}$ P. Mennell minute, 6.10.1949, FO 371/77727.

${ }^{2}$ Ibid.

${ }^{3}$ Ibid.
} 
foreign exchange involved in the deal. ${ }^{1}$ He spoke to the minister of supply and 'expressed his strong dissatisfaction at the state of affairs' and said that urgent steps needed to be taken to increase production. He also pointed out that this was not just a question of certain radar sets, as the British were currently anxious to secure their own imports from Sweden and 'we should take every opportunity to earn Swedish currency'.2

In his conversation with Bevin on 1 November 1949 the Swedish ambassador said that the dispute over the radar deliveries revealed 'considerations of a more general nature'. In 1948 Sweden had been Britain's largest export market in Europe and at the same time its greatest supplier. It had been the aim on both sides to maintain and increase mutual trade between the countries. But now there was a danger that British exports would not be able to keep pace with the British demands for essential Swedish goods, such as iron ore, timber, pulp and newsprint. This had led to an increase of Sweden's holding of sterling. Hägglöf thought that in this respect deliveries of arms and defence equipment acquired considerable importance. ${ }^{3}$ Bevin assured Hägglöf that the matter would be reexamined and that he would personally take care of it. ${ }^{4}$ In the end Bevin's intervention led to a compromise between the departments in Whitehall and with the Swedes, and the delivery of radar sets was agreed to be continued in 1950.

The problems in meeting the agreed deliveries, nevertheless, did not stop here. In August 1950 the prime minister gave an order to suspend temporarily the export of jet aircraft, until Britain's own defence needs and commitments to other powers were reviewed. Subsequently, in September the Cabinet made a decision that the defence requirements of the United Kingdom and the Atlantic pact powers superseded all other

\footnotetext{
${ }^{1}$ Bevin minute, undated, FO 371/77727.

${ }^{2}$ R. E. Barclay minute, 1.11.1949, FO 371/77727.

${ }^{3}$ Hägglöf memorandum to Bevin, untitled, 31.10.1949, FO 371/77727.

${ }^{4}$ Hägglöf to Undén, 17.11.1949, Hp $1 \mathrm{Ba}$, Vol. 99.
} 
needs. ${ }^{1}$ Despite this, there were difficulties in delivering aircraft even to Norway and Denmark. ${ }^{2}$ Britain's own requirements were in short supply due to the recent rearmament drive prompted by the outbreak of the Korean war. After the review, the production of any further aircraft for export to Sweden was suspended and only aircraft currently in production or completed, were allowed to go to Sweden. ${ }^{3}$

Thus, the existing contract was interrupted which immediately led to strong diplomatic protests from the Swedes. Their air forces' modernisation was based on the supply of British aircraft, and out of a total of 300 Vampires, only 100 had been delivered. As a retaliatory measure, the Swedish ambassador hinted that the Swedes could prevent the delivery of Bofors anti-aircraft guns to Britain, and sell them to France or Netherlands instead. ${ }^{4}$ The head of the Northern Department, Geoffrey Harrison, explained to Hägglöf that the decision had been made solely on supply grounds, and for both political and trade reasons 'there had been the utmost reluctance to interfere with the Swedish arrangement with de Havillands'.5

Faced by potential political and diplomatic problems with the Swedes, Strang called for a final ministerial decision and Bevin himself urged for a clearer policy so as to avoid similar embarrasments in the future ${ }^{6}$ In a brief to the minister of state, the case for reversing the Defence Committee decision was put forward: 'Sweden's armed forces are amongst the strongest and best balanced in Western Europe to-day and there is a very strong probability that they would fight hard to defend their independence against Soviet aggression' ${ }^{7}$ As the military appreciation was that a Soviet attack on Scandinavia would

\footnotetext{
${ }^{1}$ Note for the defence debate, 8.9.1950, Vol. 108, Attlee papers, Bodleian Library, Oxford. R. Anderson (Ministry of Supply) to Whitwell, 20.12.1950, FO 371/86948.

${ }^{2}$ Slessor to Air Chief Marshal Hugh Saunders, 31.7.1951, AIR 75/71.

${ }^{3}$ Harrison minute, 4.9.1950, FO 371/86948.

${ }^{4}$ Ibid.

${ }^{5}$ Ibid.

${ }^{6}$ Strang minute, 5.9.1950; Bevin minute, undated, FO 371/86948.

${ }^{7}$ Harrison minute, 8.9.1950, FO 371/86948.
} 
be a part of an attack on Western Europe, 'there is a little question therefore but that a militarily strong Sweden is an asset to Western European defence' ${ }^{1}$ It was also noted that the relations on the technical level between the Swedish and British armed forces were good and that the 'Swedish Services are well in advance of the Swedish Government as regards military cooperation with their Norwegian, Danish and British opposite numbers' ${ }^{2}$ Besides strategic interests, trade relations in general were endangered as well. Bevin's intervention and Hägglöf's conversation with Attlee led to a ministerial decision on 8 September 1950 that the contract for airframes to Sweden should be fulfilled and only if the production capacity of de Havillands was urgently required for United Kingdom work, might fulfillment of the contract have to be delayed. ${ }^{3}$ This was a victory for both the FO and the Swedes, but as it proved, only a temporary one.

It looked as if it was to be the same story all over again, when in October 1950 the Defence Committee decided to delay a delivery of 22 more radar sets to Sweden. ${ }^{4}$ Bevin directed his officials to clear the position up, and it was soon found out that the radars sets had already been shipped to Sweden. This 'classic muddle' revealed a tremendous lack of coordination and liaison between the different departments dealing with arms exports, where the right hand did not know what the left was doing. ${ }^{5}$ If this had been a false alarm, in December 1950 the Ministry of Supply intervened in the supply of certain machinery bound to Sweden that was used in the production of jet engines. The Ministry of Supply appeared to be struggling to meet the increasing production demands stipulated by the Ministry of Defence. Even a single piece of machinery already at the dockside in Hull, was diverted to meet the needs of the domestic industry. The problem was, that

\footnotetext{
${ }^{1}$ Ibid.

${ }^{2}$ Ibid.

${ }^{3}$ Whitwell minute, 13.9.1950, FO 371/86948.

${ }^{4}$ Etherington-Smith to the Ministry of Supply, 10.11.1950, FO 371/86947.

${ }^{5}$ Whitwell minute, 10.11.1950; Hilton-Young minute, 15.11.1950, FO 371/86947.
} 
without the equipment the Swedish manufacture of jet engines under licence was made considerably more difficult. The Swedish ambassador had an all too familiar line to present to the FO.

This time also the Board of Trade joined the FO in criticising the decision, but in the end to no avail. The concerns of the Board of Trade were similar to that of the FO, but dealt more explicitly with the problems of Anglo-Swedish trade. The Board of Trade was concerned lest decisions of this kind would be harmful to 'an important and valuable long term market', particularly as German competition was 'becoming a reality instead of a threat' ${ }^{1}$ The main complication, nevertheless, was that the incident occurred while the annual trade agreement negotiations happened to be on their final and delicate stage. As was usual, the negotiations had been protracted and with considerable difficulty an agreement was reached among other things about the levels of coal exports to Sweden and the import of 3.5 million tons of iron ore to Britain. The Board of Trade negotiators had thought that the drastic action of the Ministry of Supply at the dockside in Hull had endangered the whole agreement, but fortunately the Swedes had signed it. ${ }^{2}$ On another front, the problems caused by the Ministry of Supply could lead to political difficulties in the question of Sweden's participation in the control of East-West trade. In Cocom's activities a hole in the net of the size of Sweden would effectively make the embargo of certain strategic goods meaningless.

While the immediate reason behind the Ministry of Supply's and the Defence Committee's decision to halt the radar and jet aircraft deliveries to Sweden was the actual supply situation, it also reflected the attitude towards Swedish neutrality in departments in Whitehall outside the FO and the COS. What was known to most policy makers in Whitehall, politicians, soldiers and civil servants alike, was that Sweden had decided to

\footnotetext{
${ }^{1}$ P. J. L. Homan (Board of Trade) to C. W. Holt (Ministry of Supply), 19.12.1950, FO $371 / 86948$.

2 Ibid.
} 
remain in neutral isolation and not to undertake any responsibilities in countering the Soviet threat. A decision to stop a shipment of arms due to Sweden, was not difficult to take against this kind of perception of Swedish neutrality. The feeling was that the Swedes should learn something from this lesson and stop 'sitting on the fence'.'

What these people of course did not know, was that various steps towards establishing a working defence relationship with Sweden had already in high secrecy been taken at the service level. The problem both the FO and the COS had, was that the true nature of this cooperation could not yet be revealed outside a narrow circle in Whitehall. Cabinet ministers were not informed until 1952. Even then, the circle of British policy makers and military personnel involved was kept small and the relevant files were kept secret until 1994. The same situation applied towards the Swedes as well, and for example Swedish diplomatic representatives were kept out of the picture. ${ }^{2}$

Arms exports involved a large amount of people in different departments and also in the arms industry itself. If the nature of the embryonic integration of Swedish defence with the Atlantic pact had been revealed, the possibility of achieving a consensus in the whole administrative machine would naturally have been better. But as long as even all members of the Swedish government itself were not fully aware of the situation, there were strong security reasons for not doing this. Nevertheless, other Whitehall departments had to be persuaded to allow a more liberal policy towards arms exports to Sweden, but this was very difficult. ${ }^{3}$ The difficulties in the arms deliveries during 1950 unavoidably increased pressure on the Swedish government to find ways to secure the supplies from Britain. Perhaps, after a long period of rigid policy of neutrality, these pressures might bring about a change in this line?

${ }^{1}$ Lt.Col P. J. Dixon (WO) to Hankey, 18.10.1949, FO 371/77727.

${ }^{2}$ For example, Hägglöf to Undén, report of conversation with Harrison, 23.3.1950, Hp 1 $\mathrm{Ba}$, Vol. 101.

${ }^{3}$ Mennell minute, 6.10.1949, FO 371/77727. 


\section{Henderson's visit}

In January 1951, the Swedish government invited the British secretary of state for air, the veteran Labour politician Arthur Henderson, to visit. ${ }^{1}$ The initiative came from the Swedish side, but their wish to have discussions with a British service minister was not very surprising. ${ }^{2}$ Their air force had been built up with British assistance and material, and extensive orders and deliveries of aircraft, airframes, engines, manufacturing licences, machinery, radar etc. had been placed and shipped since the end of the war. Both the Swedish air force and domestic manufacturers, mainly SAAB, had to rely on the British to secure their vital needs. Technical cooperation between British and Swedish service authorities was also extensive, and relations on the personal level were excellent, epitomized by General Nordenskiöld's anglophile sentiments and active cultivation of his contacts in Britain, going back to the 1930s and to the time of his own training in the Royal Air Force.

The British interest in the Swedish air forces was twofold. It was the fourth largest in the world, in all consisting of about one thousand aircraft, mainly defence fighters. Many of these were now being replaced with the latest models fitted with the latest technology. This made it an important customer for the British aircraft industries. Furthermore, this air force happened to be located halfway along the direct air routes between northern Soviet Union with its military and industrial heartlands and the United

\footnotetext{
${ }^{1}$ The episode covered in this chapter was first revealed and briefly outlined in Had there been a war.., 150 - 155, receiving considerable publicity in Sweden in 1994.

${ }^{2}$ Bevin to Henderson, 5.1.1951, FO 371/94988. See Leif Leifland, 'Kommissionen står på mycket fast mark', $S v D, 4.3 .1994$, for a view that the initiative was Henderson's. The evidence for a different interpretation is found in: Farquhar to Harrison, 19.10.1950; and EtheringtonSmith minute, 24.10.1950, FO 371/86953. According to FO reporting, the suggestion came from Erlander in October 1950.
} 
Kingdom. Due to technological changes and new threat scenarios, the Swedish-controlled air space was of great interest for the RAF planners. In friendly hands it could contribute to British air strategy by providing in depth defence and early warning facilities; or be a direct route to targets in the East, bypassing the heavily defended central front in Europe.

With the rearmament drive in the West that was launched in 1950, British supplies for Sweden had come under threat. In autumn 1950 the books of the British armaments industries were full of new orders, and already limited raw materials were in high demand. Deliveries to Sweden were cancelled, delayed or only partly fulfilled. This led to numerous Swedish protests, interdepartmental disputes in Whitehall and interventions by Ernest Bevin to secure the deliveries in 1950 as described earlier. The Americans were still lukewarm about supplying neutrals with Western arms, although their attitude was changing in the spring $1951 .^{1}$ By the end of 1950 , the situation had calmed down somewhat, but the general atmosphere over Sweden's place in the priority lists of its Western suppliers was uncertain. The British representatives also sensed a certain nervousness in Sweden that the British might have been tempted to use the armaments deliveries, especially Vampire airframes, as a lever to push the Swedes into the Atlantic pact. ${ }^{2}$ That this latter fear was completely unfounded did not, however, ease the actual supply situation. As Britain's own rearmament program intensified, pressure from the Ministry of Supply to allocate more resources for home demand continued.

Thus, no-one in London was surprised when the Swedish government invited a British service minister to visit the country. Officials in the FO were keen to utilise the

${ }^{1}$ Farquhar to Morrison 23.5.1951; Purves minute, 28.5.1951; Etherington-Smith minute 29.5.1951, FO 371/94985. According to Swedish sources, the US government had finally granted export licences for radar equipment. The orders had been placed in 1948 and withheld by the US authorities until May 1951.

${ }^{2}$ Ibid. 
opportunities presented by a ministerial visit to promote closer political relations. ${ }^{1}$ Bevin was initially quite apprehensive lest the fragile truce in the dispute over armaments deliveries and over Anglo-Swedish trade relations as a whole should collapse and Henderson be involved in a political row with the Swedes that should be best handled by himself. ${ }^{2}$ Neither was Arthur Henderson particularly enthusiastic about going to Sweden. ${ }^{3}$ In the end, the potential political benefits over the possible disadvantages of such a visit convinced Bevin to support Henderson's visit. 'Opportunities for direct ministerial contact with the Swedes are not too frequent', Bevin wrote and hoped that Henderson could bring home to the Swedes that 'notwithstanding the Swedish Government's policy of neutrality, Sweden's interests are linked with those of the West'. ${ }^{4}$ There was hardly any doubt in London about the basic Western sympathies of the Swedes, but despite cautious optimism, it was still unclear how far they would be willing to go in developing the present 'considerable degree of cooperation with the United Kingdom on an official and technical level'. ${ }^{5}$ British policy at present was to 'maintain and develop such service contacts which might, if suitably expanded, be made to cover the greater part of our requirements from Sweden without political disadvantages' ${ }^{6}$

Henderson's visit took place between 18-23 January 1951. The anticipated controversy over arms exports did not arise, but something far more important did. In confidential discussions with Henderson, while Undén was 'being held in conversation by H.M. Ambassador at the other end of the room', both Erlander and Vougt admitted that 'in the event of war, Sweden expected to become involved in certain eventualities, which

\footnotetext{
${ }^{1}$ Etherington-Smith minute, 24.10.1950, FO 371/86953.

${ }^{2}$ Foreign secretary's Private Office minute 27.10.1950, FO 371/86953; minute 29.12.1950, FO $371 / 94988$.

${ }^{3}$ Henderson to Bevin, 28.12.1950, FO 371/94988.

${ }^{4}$ Bevin to Henderson, 30.10.1950, FO 371/86953; 5.1.1951, FO 371/94988.

5 'Swedish Foreign Policy', undated brief for Henderson, (January 1951), FO 371/94988.

${ }^{6}$ Ibid.
} 
included either a direct Soviet invasion of Sweden or attacks on Denmark and Norway leading to the encirclement of Sweden'. ${ }^{1}$ So far so good, but the problem was that this acknowledgment of the impossibility of Sweden remaining neutral if the Soviet Union embarked upon a campaign in Scandinavia, did not imply an adequate understanding of the problems involved in improvising military assistance for Sweden from the West.

Henderson stressed that in any future war, the Western powers could not give Sweden any effective help against aggression, 'if their knowledge of Sweden's defence plans remained rudimentary and incomplete, if not, in certain aspects, almost a "closed shop"'. ${ }^{2}$ Both Erlander and Vougt seemed to be impressed by Henderson's arguments and agreed to consider his suggestion, that 'to achieve the necessary prior coordination, the Swedish Government should give His Majesty's Government in advance a firm indication of the circumstances in which they would be prepared to fight, and should also furnish information regarding their overall strategic plans and the Swedish defence forces' ${ }^{3}$ According to Swedish records, Henderson also suggested 'government-level talks on these matters, which would be of great value for Great Britain and America' ${ }^{4}$ This was turned down by Erlander and Vougt, but it did not weaken Henderson's impression of their positive attitude.

It was no wonder then that the British ambassador in Stockholm described Henderson's visit as 'an outstanding success' ${ }^{5}$ Henderson's confidential discussions with

${ }^{1}$ Harrison minute, 13.6.1951, FO 371/94985; Etherington-Smith minute, 13.8.1951, FO 371/94985; FO brief to Herbert Morrison, 23.8.1951, FO 371/94986. The original records of Henderson's discussions have not been found in the British archives, although the material as a whole was released in April 1994. Files NW 1194/1G - 16G (of January - April 1951) are missing. However, the surviving records (from April 1951-) and the British ambassador's reports from Stockholm (released according to the 30-year rule in 1982) include enough information for a reconstruction of the talks.

${ }^{2}$ Ibid.

${ }^{3}$ Etherington-Smith minute 13.8.1951, FO 371/94985.

${ }^{4}$ Had there been a war... (1994), 150. The information is from Erlander's diary 23.1.1951 and from a record of a telephone conversation between Erlander and Vougt, 24.2.1951, ibid.

${ }^{5}$ Farquhar to Bevin, 25.1.1951, FO 371/94988. 
Erlander and Vougt seemed to confirm that the British policy of patient persuasion that Sweden should consider its defence as being a part of Western defences as a whole, was bearing fruit. Even the Swedish communists acknowledged the significance of the visit, although they hardly had any idea what passed between the ministers. 'British Inspector Visits Sweden - Atlantic Pact Agent sees all our secrets', pounded Ny Dag, the communist newspaper during the visit. ${ }^{1}$

Henderson's discussions with Erlander and Vougt without the presence of Undén increased hopes in London that Sweden might now qualify its strict neutrality in the West's favour. Even if Undén remained a serious obstacle to any fundamental reorientation of Swedish foreign policy, it was said in the Northern Department that '... the Swedish Government, despite their traditional neutral-mindedness, may gradually come nearer to our own ideas of collective security'. ${ }^{2}$ Also, the omnipotence and influence of Undén did not seem as clear cut as before. Both Erlander and Dag Hammarskjöld, seemed to exert a stronger influence on Swedish foreign policy, and were both described as more inclined towards the Atlantic powers than the foreign minister. ${ }^{3}$ And Vougt, whose character had remained somewhat of an enigma in Britain, seemed to have joined the pro-Western camp as well. Sweden, after a long period of hesitation, seemed finally to be tilting towards the West.

\section{Vougt's memorandum}

While Erlander and Vougt were considering Henderson's suggestion of giving the necessary information of their defence planning to the British, technical cooperation on

\footnotetext{
${ }^{1}$ Ibid.

${ }^{2}$ Etherington-Smith minute, 1.2.1951, FO 371/94988.

${ }^{3}$ Ibid.
} 
the service level continued. In February 1951 Undén himself authorised a team of experts from the RAF 'to study the allocation of personnel and the organisation of units in the Royal Swedish Air Force'. ${ }^{1}$ In spite the innocent appearance of the mission, Nordenskiöld added that the team would have access to all relevant material and that 'we shall keep back no secrets from the British'. The British, in turn, assured the Swedes that the information received would be treated in the strictest confidence. ${ }^{2}$ In June, a British navy unit led by HMS Indomitable and the commander-in-chief of the British Home Fleet visited Sweden. During the visit the commander had conversations with Admiral Strömbäck and General Nils Swedlund, the newly appointed supreme commander of the Swedish armed forces. From these talks it also emerged that the Swedish commanders did not anticipate Swedish neutrality to be a viable option in a future European war:

In regard to overall strategy the Admiral said the people of Sweden well understood that neutrality would not serve them in a third world war. Russia was their traditional enemy; and the recent fate of the Baltic States had destroyed illusions that some had. The people were determined to fight, and the Armed Forces were of the same mind: the question was, When? ${ }^{3}$

Strömbäck said that it was his opinion that the invasion of Denmark would bring Sweden in, some others thought of Norway. He was nevertheless not in favour of Swedish NATO membership, as it probably would not receive the kind of military assistance they needed to secure their eastern coast. Furthermore, Swedish membership in NATO might be unnecessarily provocative. ${ }^{4}$ General Swedlund, on his part, said 'how much he regretted his present inability to discuss War Plans ... he would do so, of course, before war broke

\footnotetext{
${ }^{1}$ Farquhar to Bevin, 22.2.1951, FO 371/94988.

${ }^{2}$ Ibid.

3 Summary of discussion of c-in-c, Home Fleet with Strömbäck and Swedlund, FO $371 / 94985$.

${ }^{4}$ Ibid.
} 
out'.'

These exchanges, that had been more or less routine since 1949 , seemed relatively insignificant compared to the ministerial reactions to Henderson's suggestions for a wider exchange of information. In March 1951, Vougt sent a 11-page memorandum to Henderson about Sweden's armed forces in which their war plans, organisation, strength, equipment and overall conditions for Sweden's defence were outlined in general terms. ${ }^{2}$ Even if it contained highly classified material, the memorandum added little factual information to what the British already knew from their previous conversations with the Swedish military. It was, nevertheless, enthusiastically received and keenly studied by the COS and in the FO.

The importance of the document was twofold. First, it gave firm indications about the ways the Swedes themselves thought about their defences. It was for the British a useful demonstration of how the Swedish military mind functioned and where they thought their priorities lay. Second, and more important, coming as it did from a politically responsible government minister, it was considered a significant departure compared to previous exchanges of views and information among service authorities. It was not the information in the document, but its origins, that was of most interest in London. It was the clearest sign thus far of a departure from a policy of non-alignment in peace aiming at neutrality in war, that had been the established canon of Swedish foreign policy. As recently as in March 1950, even technical military cooperation with Denmark and Norway had been considered 'an indirect engagement in the greater compact created by the Atlantic Pact' and thus 'inconsistent with the policy adopted by Parliament and the

\footnotetext{
${ }^{1}$ Ibid.

${ }^{2}$ Appendix to Chiefs of Staff Memorandum COS(51)172, 28.3.1951, DEFE 5/29, printed in Om kriget kommit... Förberedelser för mottagande av militärt bistånd 1949-1969. Betänkande av Neutralitetspolitikkommissionen SOU 1994:11, Bilagor, 147 - 158.
} 
Government'. 'Nevertheless, forms of technical cooperation that would not lead to political commitments were not explicitly excluded. ${ }^{2}$ Only staff talks and coordinated defence planning were specifically mentioned. For the British, these nuances were nevertheless irrelevant, as Vougt's memorandum clearly seemed to overstep the present self-imposed boundaries of Sweden's policy of neutrality.

On the political level and especially in London, Vougt's memorandum led to increased hopes that the problem of Swedish neutrality in Scandinavian defence might finally be solved. Nevertheless, Harold Farquhar, the British ambassador in Stockholm urged caution about spectacular advances on the political plane, as long as Undén was in charge of the Foreign Ministry. Even if it was believed that Erlander and Vougt could not act behind his back, there were no signs that Sweden would make a public U-turn in its foreign policy. But on the other hand, there seemed to be more willingness even on Undén's side to let 'admirals, generals, and air marshals of friendly countries ... on talking shop when they got together', as long as this did not lead to binding political commitments. ${ }^{3}$ This would enable effective planning for different contingencies and, at least in theory and if need arose, leave the final decisions about wartime neutrality to the Swedish government. Or if the government so chose, they could more easily align with the West if need be. This, of course, if it did not commit the Swedes to any particular course of action, and did not commit the British or any Western powers to give assistance to Sweden either. If this kind of minimum settlement suited the Swedish government, it suited the British as well. In the spring and summer of 1951 , the chances nevertheless seemed to be that more could be achieved.

Vougt's approach needed to be followed up. Sweden's position, despite all the friendly and confidential talk, was still far from clear cut. If neither the British nor the

\footnotetext{
${ }^{1}$ Had there been a war..., 52.

${ }^{2}$ Ibid.

${ }^{3}$ Farquhar to Harrison, 12.4.1951, FO 371/94985.
} 
Swedish government were willing at this stage to make headway on the political side, there was still work to be done in military cooperation that fell short of binding commitments. The understanding in Britain in the summer of 1951 was, that on the naval side the Swedes 'were prepared to go to the limit in co-operation on the Service level', and that this limit had already been reached. ${ }^{1}$ Any further coordination and cooperation between the Swedish and British navies would have required a political decision, i.e., a final departure from the policy of neutrality. On the air side, the Swedes were 'certainly willing to go to the limit', but they had not yet reached it, despite active work. ${ }^{2}$ As to the position of the Swedish army, they were far behind in this respect, though the indications were that they also were willing to develop contacts with the West. ${ }^{3}$

In May 1951 Morrison and the Minister of Defence Emanuel Shinwell agreed that Vougt should be invited to Britain in the summer for a visit, accompanied with suitable staff officers, to discuss Sweden's defences more in detail. ${ }^{4}$ As the COS said, there was plenty to talk about. The COS gave their assessment of Sweden's defences in May 1951. Their conclusions made grim reading. Combining the information already in their possession with the self-assured tone in Vougt's memorandum, their study revealed deficiencies in the Swedish defences of such magnitude that '[I]n their present state of organisation and training Swedish forces alone could do little to defend their country against a Russian attack. ${ }^{\text {s }}$ On paper, Sweden's defences looked good and previously the general COS assessment of Sweden's overall military potential had been appreciative. But based on their reading of the way the Swedes presented their capabilities in Vougt's

\footnotetext{
${ }^{1}$ Farquhar to Harrison, 27.6.1951, FO 371/94985.

${ }^{2}$ Ibid.

${ }^{3}$ Farquhar to Harrison, 4.7.1951, FO 371/94985.

${ }^{4}$ Harrison to Farquhar, 23.5.1951; Barclay to I. Montgomery (MoD), 29.6.1951, FO $371 / 94985$.

5 COS report 'Swedish Capacity to Resist Aggression', $\operatorname{COS}(51) 316,28.5 .1951$, FO $371 / 94985$.
} 
memorandum, there seemed to exist severe limitations to their value as an effective fighting force against the Soviet Union. What the British COS derived from the way the Swedes presented their case was that the Swedes did not seem to understand what contemporary warfare looked like. The problems arose mainly from Sweden's limited war experience, which had led to certain backwardness in tactical, organisational and supply questions. The undoubted bravery and commitment of the individual Swedish soldiers would be of no help if the overall structure and organisation of units above company level collapsed. In highly mobile and coordinated modern warfare, and against an enemy as experienced as the Russians, Sweden was considered a soft target. Before it could make an effective contribution to Scandinavian defence, the shortcomings listed by the COS, mostly at the higher ranks of Swedish armed forces, would need to be remedied. Otherwise, what would be the point of taking all the trouble to try to cooperate with someone who would collapse after the first blow anyway?

On the other hand, it has to be pointed out that the British military chiefs in general had a tendency at that stage to dismiss the small European armies in Montgomery's words as 'an amateur show', and were generally very pessimistic of the viability of the smaller NATO countries' defence. ${ }^{1}$ Sweden appeared to be no exception, although the extreme pessimism gradually gave way when overall Western strength grew. In the spring 1951 the COS, however, anticipated that the Swedish government would cling to their neutrality until they were actually attacked in a future war. When the attack came, they would call on the West for aid. But no previous coordination of plans would have taken place between Sweden and SHAPE's northern command except on secret and informal basis and 'consequently any assistance which could be afforded would be of doubtful effectiveness' ${ }^{2}$ As Swedish defences would collapse fast in any case, help, even

${ }^{1}$ Report of a visit of Field-Marshal Montgomery to Belgium, Holland, Denmark and Norway, 11.4.1951, FM/39, Montgomery papers, Imperial War Museum, London.

${ }^{2}$ Ibid. 
if it could be arranged rapidly, could simply not arrive in time. By the same token, the strain on Soviet forces on the central front by the diversion to north would be of lesser magnitude.

The only way forward was coordination of planning between Sweden and Western powers before war broke out. This would have to be combined with continuing efforts to bring home to the Swedes the realities of present day warfare, as the British saw it. As the attitude of the Swedish government was well known, this could not take forms of firm defence agreements and would not be as effective. Nevertheless, secret and informal consultation in peacetime with the Swedish authorities 'in order to exchange information and achieve some co-ordination of plans for the defence of Scandinavia', would provide opportunities for obtaining more information on Swedish intentions, particularly with regard to defence of Denmark. This 'might prove very advantageous'. ${ }^{1}$ In other words, Sweden's membership in NATO was not necessarily a prerequisite for adequate planning of the effective defence of Scandinavia. This could be done on a lower level, among experts. But even this was difficult under existing political conditions.

What was needed at this stage was an agreement - tacit if necessary - by the Swedish government to coordinate their defence plans with the West. The real work could then be started in secret with informal talks between the United Kingdom, Sweden, Norway and Denmark. In the future these informal talks should, if possible, be carried forward to a point 'which would allow co-ordinated military planning to take place'. Until such coordination was achieved, both Sweden's and NATO's chances of successful defence of its northern flank remained small. Without such steps, Sweden's efforts would 'contribute little to Western European defence generally' and NATO powers' efforts would be of little help to Sweden.

In order to remedy the situation, Vougt was needed in London, accompanied with

\footnotetext{
${ }^{1}$ Ibid.
} 
suitable senior officers. The idea was that Shinwell would hand him a British memorandum setting out the COS observations of the weaknesses of the Swedish defences and probable Soviet tactics and suggesting remedies to improve the situation. The 'delicate part of the operation', would be 'a suggested oral amplification by $\mathrm{Mr}$. Shinwell of the need for the Swedes to co-ordinate their defence plans with the West'. Vougt, if he came to London, would hardly be entering the lions den, but the crucial decision would have to be taken by the Swedes as to whether to go beyond the point of no return, i.e., make definite plans of coordination of defences with the West and in effect integrate Swedish defences to wider NATO planning - a farewell to neutrality policy.

\section{Cold feet in Sweden}

By now, the Soviets had become suspicious about the Anglo-Swedish talks. A belief that something more was going on under the seemingly calm surface of Swedish policy of neutrality was not a new phenomenon in Soviet thinking. ${ }^{2}$ As Petersson has recently pointed out, the Soviet Union saw very soon after the war that the fine tuning of Sweden's neutrality was a potential bone of contention between it and Britain. In May 1951, Lord Montgomery's remarks during a visit in Denmark, that Sweden would eventually take the West's side in a future war aroused interest in Moscow. ${ }^{3}$ The Soviet ambassador in Stockholm, Konstantin Rodionov then began his 'cross-examinations' of Swedish politicians about the direction of Sweden's defence policy. In May 1951, Allan Vougt tried to answer Rodionov's searching questions about military cooperation between

\footnotetext{
${ }^{1}$ Harrison minute, 13.6.1951, FO 371/94985.

${ }^{2}$ Petersson, Med Moskvas ögon, 40 - 47.

${ }^{3}$ Ibid, 51 .
} 
the Scandinavian countries as well as he could, but had to acknowledge the fact that the Swedish defence chiefs tended to regard Sweden's defence in connection with that of the region as a whole. Rodionov also pointed out to Vougt, that military contacts between Sweden and Britain had recently increased and this growth was so strong that 'there had to be a deeper explanation' . ${ }^{1}$ Rodionov spoke also with Undén and Hammarskjöld, who were at pains to assure the suspicious Soviet ambassador that Swedish foreign and defence policies were based on the government's public declarations.

Soon after the conversation with Rodionov, Vougt put on the brakes in the issue of further talks with the British. The decision of postponing, but not definitely cancelling, Vougt's visit to Britain seems to have been taken between 2 - 5 June 1951. Erlander and Vougt had made an opening, perhaps felt as a concession, in return for continued British goodwill regarding the delicate situation in arms exports, but were not prepared to take further steps now. Vougt nevertheless did not want to close the door completely and he told the British that he personally favoured the invitation. He said that, for the time being, the visit should be postponed until September in order to avoid suspicions against him or his government. Various Anglo-Scandinavian exchanges of visits had taken place and were scheduled, such as Swedish and British naval visits, and Vougt hoped these could be 'more spread out'. ${ }^{2}$ Morrison understood well the delicacy of the Swedes' position, and said in early June that they should not be frightened 'unduly' as 'we may be able to persuade and bring them along gently (indeed they are coming) but the Swedes can't be "pushed around"'. ${ }^{3}$ Morrison referred to his close personal relations with the Swedish social democrats, and Tage Erlander in particular, whom Morrison described as 'a good friend' whom he respected. ${ }^{4}$ Morrison urged patience and tolerance in dealing

\footnotetext{
${ }^{1}$ Ibid.

${ }^{2}$ Farquhar to Harrison, 5.6.1951, FO 371/94985.

${ }^{3}$ Morrison minute, 2.6.1951, FO 371/94985.

${ }^{4}$ Ibid.
} 
with the Swedes. ${ }^{1}$ The Labour government, during both Bevin's and Morrison's time in the FO, wanted no deals behind the backs of the key ministers of the Swedish government.

At the same time as progress with the Swedes on the ministerial level was slowing down, the problem of the relationships and roles of the different Western organisations interested in secret military cooperation with the Swedes was discussed in London. It was understood from the very beginning that the issue was most sensitive and should be kept as secret as possible. This was the most important factor in deciding which organisations, which countries and which personnel would be in charge of covert contacts with the Swedes. Secrecy was considered so important on the British side, that other NATOpowers, including the Americans, were not initially considered fit to share the AngloSwedish secrets. Also NATO, and its European headquarters SHAPE in particular, was problematic from this viewpoint. ${ }^{2}$ The whole problem revolved around the question of the extremely delicate position of the Swedes who were willing to go ahead with defence cooperation with the West. It was recognised that the Swedes were playing with very high stakes. 'If we play our hand carefully, and above all, secretly, there are distinct possibilities of further progress. If, on the other hand, the Swedes learned that we were informing others of the informal exchanges between us and themselves, there would be serious risk of their retiring into the shell out of which, with great care, we are beginning to coax them' ${ }^{3}$ It was agreed in June 1951 that cooperation with the Swedes would proceed on bilateral Anglo-Swedish basis. ${ }^{4}$

Nevertheless, some guardians of the special relationship with the Americans insisted that the senior partner in the Atlantic alliance should and could not be kept in the dark.

\footnotetext{
${ }^{1}$ Morrison minute, 27.6.1951, FO 371/94985.

${ }^{2}$ Harrison minute 13.6.1951, FO 371/94985.

${ }^{3}$ Ibid.

${ }^{4}$ Shinwell to Morrison, 1.6.1951, FO 371/94985.
} 
Both Sir Roger Makins and Sir Pierson Dixon wanted to inform the Americans of the developments on the Swedish front, especially their Joint Chiefs of Staff and SHAPE. ${ }^{1}$ Morrison saw the merits of this and suggested that only General Dwight D. Eisenhower (Supreme Allied Commander Europe, SACEUR) be informed 'orally in strict and personal confidence', but no other NATO powers or SHAPE besides the general. ${ }^{2}$ Eisenhower was duly informed by Morrison on 3 July 1951, who said that the British had 'certain informal contacts with the Swedish Minister of Defence, and at the Service level', but that nothing conclusive had yet emerged. ${ }^{3}$ Eisenhower appreciated that the question needed careful handling and let the British understand that he would 'exercise the utmost discretion in the matter' ${ }^{4}$ As the British understood it, this meant not informing American authorities in Washington. At the same time, as a part of the 'flank strategy' of early NATO strategic thinking, Eisenhower had set his eyes firmly towards Sweden. He saw it - like the British had done since 1947 - as a vital barrier between the Soviet Union and the weakest elements in the alliance, Norway and Denmark. ${ }^{5}$ But otherwise, on the practical level, the whole issue was still firmly kept in British hands.

Vougt's hesitations in setting up a firm date for his visit to Britain led the ambassador in Stockholm to speak against expecting too much from the Swedes. The British should not expect too large a dividend as a result of a possible visit by Vougt to London. 'To put it bluntly we none of us here have any indication as to exactly how far the Swedish Government are prepared to go - or indeed how much is going on behind their backs' ${ }^{6}$ Despite the 'faint indications' that some ministers were prepared to turn a blind eye to the activities of the Swedish military planners, Sweden was still firmly anchored to the

\footnotetext{
${ }^{1}$ Makins minute, 5.6.1951; Dixon minute, 5.6.1956, FO 371/94985.

${ }^{2}$ Morrison to Shinwell, 27.6.1951, FO 371/94985.

${ }^{3}$ Harrison minute, 3.7.1951; Morrison minute, 3.7.1951, FO 371/94985.

${ }^{4}$ Harrison to Farquhar, 10.7.1951, FO 371/94985.

${ }^{5}$ Hägglöf, Engelska àr, 210 - 211.

${ }^{6}$ Farquhar to Harrison. 4.7.1951, FO 371/94985.
} 
policy of neutrality. Due to the hesitations of the Swedish ministers, Farquhar advised that even Vougt, whom he described as 'an astute and somewhat wily old fox', should not be informed what had been going on between the Swedish and British military authorities 'under the counter'. 'In my humble opinion it would be very unfortunate if M. Vougt discovered that more had been going on than he was aware of, or that his government would approve of'. ${ }^{1}$ If the Swedish government got a true idea of the extent of British knowledge of Swedish defences 'some of our best friends in the Swedish Armed Services might get into serious trouble with disastrous effects on our unofficial, but nevertheless useful, cooperation'. ${ }^{2}$ Harrison assured the ambassador that this was being taken care of in London. ${ }^{3}$ This high level of secrecy was meant also to cover conversations with members of the Swedish embassy in London.

As it happened Hägglöf in London was initially completely out of the picture, but not for very long. The number of people aware even on general lines of the HendersonVougt exchanges in Stockholm was very low. This Byzantine secrecy was nevertheless difficult to grasp by everyone in London. On 5 June, Morrison himself told Hägglöf in London how pleased he was that Vougt was coming for a visit. As Hägglöf had no idea what Morrison was talking about but was not keen to show his ignorance, he only replied that 'the recent naval visit [of a Swedish navy unit to London] had shown the value of personal contacts between the two countries'. ${ }^{4}$ And more followed. During a Royal banquet Lord Fraser, the commander-in-chief of the British Navy expressed his satisfaction that Vougt was coming over, hopefully with some of the defence chiefs. He also stressed that the friendship between the two navies was far more important 'than all

\footnotetext{
${ }^{1}$ Ibid.

${ }^{2}$ Ibid.

${ }^{3}$ Harrison to Farquhar, 16.7.1951; Harrison to Brigadier R. W. Ewbank (MoD, COS Secretariat), 1.8.1951 instructing service departments to observe the policy advised by Farquhar, FO $371 / 94985$.

${ }^{4}$ Hägglöf till Undén, 6.6.1951, Hp $1 \mathrm{Ba}$, Vol Hp 247.
} 
pact-questions'. ${ }^{1}$ After Lord Fraser, also the chief of the RAF, Sir John Slessor spoke to Hägglöf. He alike without doubt acted in good faith assuming that Hägglöf would be aware of the situation. In effect he only increased Hägglöf's and subsequently Undén's apprehensions about the possible implications of Vougt's visit to Britain. Slessor said that he was also looking forward to meeting Vougt in London, but unlike Morrison or Fraser, Slessor mentioned that 'he had read with interest the Swedish memorandum'. ${ }^{2}$ By now, Hägglöf was extremely interested what was going on, and Undén in Stockholm had no illusions as to what kind of reactions Vougt's memorandum had triggered in London. This led the Swedish Foreign Ministry to become increasingly involved in the issue, if it had not woken up before.

Hägglöf's conversations with the British military led him to write later in his memoirs that at the time 'different English representatives threw once in a while ideas about cooperation with Sweden, which stood outside the Atlantic group' ${ }^{3}$ Was not there a possibility that a certain understanding could be reached about Sweden's position in Scandinavian defence, he was asked. 'I, of course, discarded all such proposals without even asking Stockholm'. ${ }^{4}$ On 22 July 1951 he warned Undén about the dangers involved in the present increasing informal relations between the British and Swedish military. There was nothing wrong as such in fostering good relations between them, but the prospects it opened should be kept in mind. 'I do not know, whether you at home have a really good idea, how frequent these military visits are, as they are organised by so many different Swedish organisations' ${ }^{5}$ The visits, that of course could also be perfectly harmless, had nevertheless recently been of increasingly general nature and the issues

\footnotetext{
${ }^{1}$ Ibid.

${ }^{2}$ Ibid. There is a questionmark on the margin of the document here, most likely by either Hammarskjöld or Undén.

${ }^{3}$ Hägglöf, Engelska àr, 211.

${ }^{4}$ Ibid, 211.

${ }^{5}$ Ibid.
} 
discussed had come dangerously close to foreign policy. The British COS were closely involved in these exchanges, and they in turn were within the inner circle of Attlee's Government. Hägglöf saw that the COS's role had considerably increased in Britain compared to the prewar period and even Attlee himself took regular advise from the COS on foreign policy as well as on military questions. Even in the future, with possibly the Conservatives in government, the $\operatorname{COS}$ was expected as being able to retain their influential position. ${ }^{1}$ Hägglöf pointed out that if the Swedish military had frequent contact with the British Chiefs, it in fact was closely involved with political as well as technical military questions. The Swedish military could not of course enter into political commitments and in this respect these contacts were not directly prejudicial to Sweden's official foreign policy. If, on the other hand, Vougt now came to London, he 'could scarcely avoid of being dragged into discussions about Sweden's foreign and defence policies of very difficult character' ${ }^{2}$ Hägglöf made clear that Vougt's visit could lead to problems for Undén's foreign policy.

Against this background, the almost inevitable reaction from Undén came soon. Vougt cancelled the planned visit altogether in early August. Referring to parliamentary duties and a busy schedule, Vougt postponed the issue indefinitely. ${ }^{3}$ The real reasons behind Vougt's 'defection' were immediately seen to be of political nature.$^{4}$ It was held that the Swedish government, Undén especially, had vetoed the visit. Before Vougt sent his memorandum to Henderson, Erlander had read it and agreed with its contents, but according to a later remark in his diary, his 'vigilance was off guard somewhat' since he thought that Undén would review it in any case. ${ }^{5}$ This did not happen, however, as

\footnotetext{
1 Ibid.

2 Ibid., $212-213$.

${ }^{3}$ Vougt to Shinwell, 1.8.1951, FO 371/94985.

${ }^{4}$ Etherington-Smith to Lambert, 13.8.1951, FO 371/94985.

${ }^{5}$ Had there been a war..., 254, quoting Erlander's diary 14.9.1951.
} 
neither Undén nor Hammarskjöld saw the paper before it was sent. Undén had agreed that 'Henderson's proposition on talks should be met with a memorandum of informative character'. ${ }^{1}$ Later in September when Hammarskjöld had become familiar with the contents of the memorandum, he pointed out that the 'tactical-strategic deliberations in the memorandum were dangerous, as they invited the British for further discussions'.2 By then also Erlander, in fear of Soviet reactions, had become more cautious about developing contacts with the British, and as he confided to the supreme commander, General Swedlund in October: '[he] was afraid that the British, who were much more dangerous, i.e. more skilful than the Americans at a suitable moment would compromise us by insinuations of cooperation tendencies'. 3

The Swedish commission could not ascertain what the role of the Swedish military had been. Neither could they locate a copy of the memorandum in Sweden. ${ }^{4}$ It is most likely, judged by later events, that Undén in the first place considered the memorandum a defensive measure against British overtures, and not as a new opening for further cooperation. When it was realised that the British saw the issue this way, an impression that was enhanced by Hägglöf's reporting from London, Undén quickly rallied the Swedish government back to the fore.

This reversal disappointed the British. For a while it had seemed that the Swedes would finally come off the fence and begin serious military talks with them. Vougt himself clarified the reasons for his retreat in Stockholm by saying to the British naval attaché: 'You must realise that while we are prepared to go on giving you information, and we want to convince you that Sweden will fight if attacked, we cannot go further than that. I am afraid that when Mr. Henderson was here he got a slightly misleading

\footnotetext{
${ }^{1}$ Had there been a war..., 150, quoting Erlander's diary, 14.9.1951.

${ }^{2}$ Had there been a war..., 151 - 152, quoting Erlander's diary 14.9.1951.

${ }^{3}$ Nils Swedlund's diary, 19.10.1951, Krigsarkivet, Stockholm.

${ }^{4}$ Had there been a war..., 150.
} 
impression of what we were prepared to do'. ${ }^{1}$ Of course, what had had the greatest impact on British thinking had been his memorandum, not Henderson's conversations. Hence, the British interpretation was that Vougt had again consulted his colleagues, and had pointed out that the visit would probably lead to a proposal of some form of staff talks. This had, according to British representatives in Stockholm, led the government to take a considered decision against the visit. ${ }^{2}$ It seems, that Vougt was now desperately trying to save as much of his domestic political capital as possible. As a minister, his days were nevertheless numbered.

As the exchanges between the defence ministers Shinwell and Vougt seemed to be heading into a dead end, the FO, in order to keep the ball rolling, decided to utilise the personal link between Morrison and Erlander. ${ }^{3}$ As he had a habit of doing, Morrison was in August on his way to Sweden for a holiday, which offered chances to meet his social democrat friends, namely Erlander, in a private capacity. Morrison was not advised to put any pressure on his Swedish friends, as the previous policy of patience was still considered the best course. ${ }^{4}$ But he was nevertheless advised to mention that Sweden would not be in a position to receive any effective help in war from the West if there was not 'some degree of defence coordination'. ${ }^{5}$ Military assistance for Sweden could not be rapidly improvised and it was 'in fact unlikely that any early assistance could be given' ${ }^{6}$ Furthermore, as the defence of Scandinavia could only be considered as a whole, it was very difficult to prepare any defence planning for NATO's northern flank without being

\footnotetext{
${ }^{1}$ Lambert to Etherington-Smith, 16.8.1951, FO 371/94986. Quoted also in Had there been a war..., 151 .

${ }^{2}$ Lambert to Etherington-Smith, 16.8.1951; Strang minute to Morrison, 23.8.1951, FO $371 / 94986$.

${ }^{3}$ Etherington-Smith to Lambert, 20.8.1951, FO 371/94986.

${ }^{4}$ Etherington-Smith minute, 13.8.1951, FO 371/94986.

${ }^{5}$ Ibid.

${ }^{6}$ FO brief to Morrison, 23.8.1951, FO 371/94986.
} 
able to count on Sweden's participation 'in certain eventualities'. ${ }^{1}$ Morrison should impress the Swedes of the basic ideas of Britain's policy:

The necessary degree of defence coordination between Sweden and the Western Powers can be achieved, if there is the necessary consultation between the defence authorities, without prejudicing Sweden's policy of formal neutrality. We would therefore hope that exchanges with the Swedish authorities might develop on this basis until the minimum degree of cooperation and coordination, which appears so essential in our common defence interest, has been realised. ${ }^{2}$

This could be achieved if the Swedish government let their service authorities conduct secret talks and allow 'a minimum of tacit cooperation to take place' with the British. ${ }^{3}$ It could be done quietly, without prejudicing Sweden's official policy of neutrality, which the British 'respected'. ${ }^{4}$ However, it was essential to be careful not to disclose what already was going on on the service level, as it was not believed that Erlander was fully aware of the extent of the present exchanges. ${ }^{5}$

Before Morrison met Erlander in Sweden, the COS were careful to discourage him from saying anything that would actually count as a promise of effective military help if the Swedish government decided to come off the fence. ${ }^{6}$ The British needed the participation of Sweden in the defence of Scandinavia more than they were prepared to help Sweden. The reluctance of the British COS to assume any responsibility to actually defend the Scandinavian NATO-members, besides keeping sea lanes open with the British navy or indirect help by the strategic bombing offensive, had been a constant feature of its strategic thinking since 1948. In the discussions in the Northern Regional Planning

\footnotetext{
${ }^{1}$ Ibid.

${ }^{2}$ Etherington-Smith minute, 13.8.1951, FO 371/94986.

${ }^{3}$ Draft brief for Morrison, undated, FO 371/94986.

${ }^{4}$ Etherington-Smith to Lambert, 20.8.1951, FO 371/94986.

5 Mason's comments on Etherington-Smith minute, undated (probably 13.8.1951), FO

${ }^{6}$ Etherington-Smith minute, 22.8.1951, FO 371/94986.
} $371 / 94986$. 
Group the UK representative had insisted that the main threat to Scandinavia and Norway in particular was not maritime, but overland, where the main burden would fall on Norwegian and Swedish shoulders. ${ }^{1}$ This strategic assessment was of course very convenient for the overstreched British forces. If the threat was maritime, the British would obviously have had to do something about it.

Briefs for Morrison had to be more cautious in this respect than the FO would have preferred. ${ }^{2}$ The link between Swedish will of cooperation and effective and early Western assistance in war could not be made explicit. Considering the very high stakes with which the Swedish government was playing, Morrison did not have a particularly strong hand to play. If the Swedish government had concluded that neutrality brought more security to Sweden than NATO-membership, they would need some hard persuasion that this was not the case.

With the reservations of the COS in mind, Morrison took a very cautious line in his conversations with Erlander in late August 1951. In the 'Halmstad conversations', as they were dubbed by Hammarskjöld, if Morrison was cautious and noncommittal, then so was Erlander. ${ }^{3}$ When Morrison told him that the British would welcome more information of Swedish defence plans, Erlander was surprised 'because he had the clear impression that such information had been supplied' ${ }^{4}$ Morrison said that a memorandum had been received but suggested that further private talks should be arranged through service channels. Erlander did not respond immediately and after Morrison 'pressed him again' he only went as far as to say he would give it thought and consideration. Otherwise the talk of the two fellow social democrats, who were on Christian name terms with each

\footnotetext{
${ }^{1}$ Archer, Uncertain Trust, $18-19$.

${ }^{2}$ Strang to Morrison, 23.8.1951, FO 371/94986.

${ }^{3}$ Lambert to Etherington-Smith, 26.9.1951, FO 371/94986.

${ }^{4}$ Morrison to Lambert, 6.9.1951 (record of conversations with the King and prime minister of Sweden), FO 800/657.
} 
other, was cordial and Morrison described their friendly relations 'such that it could not well be otherwise'. ${ }^{1}$ But, as Hammarskjöld later put it, the net result of the talks was 'status quo ante'.2

Despite the tight veil of secrecy over the contents of Morrison's talks, his visit to Sweden was not left unnoticed by the international press. The New York Times wrote on 1 September: 'Informed sources said that Mr. Morrison was using this occasion to deliver what they described as "a strong sales talk" on the joint Western defense to both the King and Mr. Erlander'. It was believed that the British were trying to 'sell them some formula of bringing neutral Sweden into a closer liaison with the Western defense program without actually asking Stockholm to join the Atlantic alliance' ${ }^{3}$ Reports that came as close to the mark as this, did not make the Swedes any more eager to step up military cooperation with the West.

\section{Loss of ministerial contact}

After the lack of further progress with Erlander and Vougt, the British were left with the problem of how to continue: Be content with the exchanges on service level and develop these, or try to press forward on the political plane. And what to do with the COS assessment of Swedish defences? Continuing on the political level would evidently bring more benefits, if an agreement could be reached about the extent of cooperation on lower levels. If not, the Swedish service authorities had shown their willingness to carry on nonetheless. The complicating factor was that covert military cooperation could hardly be separated from Britain's political relations with Sweden as a whole and in this respect

\footnotetext{
${ }^{1}$ Ibid.

2 Lambert to Etherington-Smith, 26.9.1951, FO 371/94986.

3 'Morrison said to ask Swedish defence aid', New York Times, 1.9.1951
} 
the problem of what to do with Undén and the Foreign Ministry in general had to be solved.

The British representatives in Stockholm had very good and confidential relations with the Foreign Ministry officials. The same applied to relations between the FO and Swedish diplomats in London and with the military in general. Even if the British thought that Erlander did not always share his inner thoughts with his colleagues, the game, if it had to be played behind Undén's back, seemed risky. The British might appear to be playing off one Swedish minister against another and interfering in Swedish domestic politics. Also the consequences of the British being responsible for trouble inside the Swedish administration 'owing to individual officers taking steps which were not in accordance with the policy of the Swedish Government', could be very harmful politically. ${ }^{1}$ It had taken four years to 'achieve the very limited progress which has been made so far' and the future did not seem to promise any spectacular advances. ${ }^{2}$ But could the British realistically believe in effective defence coordination with Sweden without at least the passive consent of the Foreign Ministry? And if this was not sought, what would the consequences be both for existing ministerial contacts and Anglo-Swedish relations as whole, if the Foreign Ministry came to know what had been going on behind their backs? A false move could well undo much of the patient groundwork that had been done this far, not to speak of considerable damage to Anglo-Swedish relations in other fields.

The Northern Department was extremely sceptical that a direct approach to Undén would take the issue anywhere. On the contrary, if Undén's suspicions were aroused, the situation might actually worsen. The line proposed in September 1951 was to go on developing service contacts, 'supported where occasion offered by personal meetings between British Ministers and well-disposed Swedish politicians like M. Vougt and M.

\footnotetext{
${ }^{1}$ Hohler minute, 21.11.1951, FO 371/94986.

${ }^{2}$ Etherington-Smith minute, 21.10.1951, FO 371/94986.
} 
Erlander'. ${ }^{1}$ Hammarskjöld, now the secretary general of the Foreign Ministry, encouraged this approach as he himself did not believe Morrison's proposals for staff talks would be well received by Undén. Anthony Lambert from Stockholm reported Hammarskjöld saying: 'The only sensible thing to do was to go on developing contacts through the usual channels (I think he meant service channels) until the moment came when the political decision on the part of the Government would impose itself by the force of circumstances'. ${ }^{2}$ Hammarskjöld understandably asked that these comments would be considered strictly off the record and 'treated with the utmost discretion', and that it was the civil servant half, not the cabinet minister half talking. ${ }^{3}$ In short, even if Sweden would not take sides in the cold war now, everything should be done in order to make the transition as smooth if and when the moment of truth came.

If the cooperation on service level was to become effective, the British service representatives in Stockholm would be in a crucial position. Later in November 1951, when this aspect was further discussed in London, the service departments agreed that the attachés in Stockholm could be so briefed that they would have the full ability to conduct the necessary talks with the Swedish officers. ${ }^{4}$ The service attachés would also have to be competent soldiers with all the relevant operational qualifications for effective action in an emergency. Also the Swedish ambassador in London said that 'what was really required was a high ranking Staff Officer', if not only in Stockholm, then possibly covering Denmark and Norway, or possibly Finland as well. ${ }^{5}$

The advice of the Northern Department was that the more the issue could be considered a purely military one, the less Undén would have reason for complaint. As

\footnotetext{
${ }^{1}$ Etherington-Smith to Lambert, 17.8.1951, FO 371/94986.

${ }^{2}$ Lambert to Etherington-Smith, 26.9.1951, FO 371/94986.

${ }^{3}$ Ibid.

${ }^{4}$ Stevens minutes, 26.11.1951; 27.11.1951, FO 371/94986.

${ }^{5}$ Stevens minute, 22.11.1951, FO 371/94986.
} 
it was now more modestly thought that Britain's minimum immediate requirements could be largely met without introducing political aspects, there seemed to be no reason to have Undén put in the picture. Thus, it was suggested that a reply to Vougt's memorandum should be communicated back to him and 'nothing at all about all this should come to the knowledge of the Ministry of Foreign Affairs'. ${ }^{1}$ If Undén was an immovable stumbling block between Sweden's adherence to NATO, perhaps this block could be bypassed altogether?

But, despite all this self-assuring reasoning, entering staff talks aiming at defence coordination with a foreign power - especially a neutral one - was definitely a political and not only a military or technical question, even if some in London thought otherwise. If Anglo-Swedish military cooperation was to be developed from the existing technical and informal level, some kind of political understanding was necessary. Lambert agreed that existing service cooperation should be worked on, and foundations for a possible ultimate political understanding be laid. ${ }^{2}$ He suggested that the whole question should be also discussed with selected permanent officials at the Foreign Ministry who, on the long run, were 'among our best allies' ${ }^{3}$ Not that they would necessarily be on the British side in the issue, but that they had already shown a willingness to discuss a wide range of controversial problems dispassionately with the British. A policy of openness with them would also not endanger the present relations of mutual confidence. ${ }^{4}$ But in the question of the part the Americans were thought to have, British representatives in Stockholm agreed that at the present delicate stage the British had better keep all the strings in their own hands. ${ }^{5}$ A bilateral Anglo-Swedish link was the safest option and an US intervention

\footnotetext{
${ }^{1}$ Etherington-Smith to Lambert, 17.9.1951, FO 371/94986.

${ }^{2}$ Lambert to Etherington-Smith, 26.9.1951, FO 371/94986.

${ }^{3}$ Ibid.

${ }^{4}$ Ibid.

${ }^{5}$ Ibid.
} 
in Stockholm was definitely not called for. These dilemmas remained unsolved, when new developments took place in high politics.

First, the Swedish government was reshuffled by Erlander in October 1951. The social democrats formed a new coalition with the Agrarian Party, and Vougt was replaced by another social democrat, Torsten Nilsson, as the new defence minister. The new defence minister still had his teeth to cut in Swedish politics, which strengthened the position of both Undén and Erlander in overseeing defence policy. The message that was implicit in the Agrarians' inclusion in Erlander's cabinet and Vougt's departure from the Ministry of Defence was not left unnoticed in London. The Agrarians had perhaps the most consistent record of support for strict policy of neutrality and even isolation in Sweden. Even if Vougt said that he briefed his successor of the situation, the British had no certainty whether Nilsson would be as forthcoming as Vougt had been. ${ }^{1}$

Second, in October Attlee called a general election in Britain which resulted in a Conservative victory and in the formation of Winston Churchill's government. All the personal and confidential links that had been painstakingly forged between ministers disappeared overnight. They had largely been based on the personal friendship and acquaintance between ministers, which had been strongly fostered by Labour's key figures; Bevin, Morrison, Cripps and Attlee had all spoken for closer relations with the predominantly social democratic Scandinavians and the Swedes. Now, it was doubtful whether a same kind of channel could immediately be established with a new government in Britain. ${ }^{2}$ Furthermore, the Swedes were apprehensive lest a change of government in Britain would end the previous understanding attitude towards Swedish policy of neutrality and lead to political pressure on Sweden. ${ }^{3}$ If the COS's critical comments on

\footnotetext{
${ }^{1}$ Etherington-Smith minute, 21.10.1951; Mason minute, 22.10.1951, FO 371/94986.

${ }^{2}$ Ibid.

${ }^{3}$ Hägglöf to Undén, 27.10.1951, Hp $1 \mathrm{Ba}$, Vol HP 248. Lambert to Harrison, 1.3.1950, FO 371/86142; Wright to Eden, 18.6.1952, FO 371/99082; Wuori to Foreign Minister Ảke Gartz,
} 
Swedish defence were now communicated back to Sweden and Morrison's suggestions of staff talks were repeated by the new foreign secretary, Anthony Eden, this might well be interpreted as a sign of a departure from the Labour government's policy. The FO was afraid that this could spoil the whole situation. ${ }^{1}$

There the situation rested, with no fresh initiatives or decisions on the British side. The COS's comments on the Vougt memorandum would remain uncommunicated to the Swedes, until the new government made a decision on how to proceed on defence cooperation with Sweden in the future. The options for Eden were either to continue the roundabout methods of personal contacts behind the back of Undén, or through the normal channel of the Foreign Ministry with the subsequent risks of countering stiff opposition. In any case, in the near future the whole question would have to be handled more on the basis of officials' contacts rather than between ministers. ${ }^{2}$ Until any further decisions or developments, the political situation had gone back to square one.

An old policy for a new government

Soon after taking office, the new Conservative government in London began to formulate their policy towards Sweden. Despite the lack of personal contacts with Swedish ministers or any particular sympathies towards Scandinavian social democrats in general, the Churchill government's policy towards Scandinavia as a whole showed a remarkable degree of continuity to that of the Labour government. This was despite the fact that both Churchill and Eden had a reputation of being more critical about neutrality, and had not

\footnotetext{
15.5.1950, AFMA.

i Stockholm telegram to FO, 11.10.1951; Etherington-Smith minute, 21.10.1951, FO $371 / 94986$.

${ }^{2}$ Hohler minute, 21.11.1951, FO 371/94986.
} 
been particularly impressed by Sweden's actions in the Second World War. However, fears that the new government would be prone to side with the Americans in a tougher approach towards Swedish neutrality proved soon unfounded.

The first occasion when the new Conservative government's attitude towards Sweden was clarified was when Eden saw the Swedish ambassador in December 1951. The most sensitive issues of defence cooperation were not touched upon in the conversation, but both agreed that 'Sweden should not be a source of weakness in Europe'. Eden stressed in particular that 'a Swedish neutrality of the old-time variety', as he had known it in the thirties, would be a real cause of anxiety in the West. ${ }^{1}$ Eden himself was 'no enthusiast of the neutrality principle', but nevertheless understood that 'it was not a practical policy to discuss Swedish membership in the Atlantic Pact'. ${ }^{2} \mathrm{He}$ assured Hägglöf that he understood that Sweden stood in a special position and had the capacity to organise a good defence force independently, but that some of the British defence chiefs felt a need for more defence information. In order to avoid any misunderstandings, Eden said that 'I understand your position and I do not want in any way to push you to do something that is not in accordance with your political line'. ${ }^{3}$ Hägglöf could report back to Stockholm that Eden had 'a definitely positive attitude' towards Sweden. ${ }^{4}$ No change in Britain's basic attitude, despite the change of government, seemed imminent.

Hägglöf continued the conversation with H.A.F. Hohler of the Northern Department, when defence cooperation was also discussed in more detail. Hägglöf followed the cautious lines set by Tage Erlander in Halmstad in August and said that he believed the British now had all the information they required about Swedish defence. Unlike Erlander, Hägglöf nevertheless assured him that if something was lacking, 'he did not

\footnotetext{
${ }^{1}$ Eden to Lambert, 4.12.1951, FO 800/819.

${ }^{2}$ Hägglöf to Hammarskjöld, 5.12.1951, HP $1 \mathrm{Ba}$, Vol. 248.

${ }^{3}$ Ibid.

${ }^{4}$ Ibid.
} 
doubt it could be obtained'. ${ }^{1}$ Hägglöf understood that relations were very close between the navies and air forces, and hoped the cooperation between the armies would be gradually improved. ${ }^{2}$ This seemed to confirm the view that if Sweden was not willing to break any new ground on the political plane, information exchanges could continue.

But the problem in December 1951 was no longer one of information. What was needed were conversations 'which would enable the British Service Chiefs to bring home to the Swedes the inadequacy of their existing arrangements'. ${ }^{3}$ Anthony Nutting wondered whether the Swedes were 'coming our way at all', even if Hägglöf showed a positive and cooperative attitude in general. ${ }^{4}$ Etherington-Smith of the Northern Department was now more pessimistic about the chances of developing closer defence relations with Sweden, and in fact the indications were that the contrary could be the case. ${ }^{5}$ The optimism of the earlier part of the year had rapidly disappeared after Vougt's cancellation of his visit, his departure from the Swedish government, after Erlander's 'unforthcoming attitude', and in view of the government reshuffle which had strengthened 'the factors in Sweden which favour isolationism'. ${ }^{6}$

To clarify the situation, the FO prepared a submission to ministers in February 1952. Eden presented it to the Cabinet's Defence Committee in early March 1952, and it was subsequently accepted as a general guide in the further handling of the problem. The memorandum was based on the COS's earlier studies of the strategic importance of Scandinavia in a future war and of Sweden's position in particular. The COS considered Scandinavia 'an area of great importance in Western defence strategy' where Swedish cooperation was essential. Until coordination of Sweden's defences with the West was

\footnotetext{
${ }^{1}$ Hohler minute, 10.12.1951, FO 371/94986.

${ }^{2}$ Ibid.

${ }^{3}$ Ibid.

${ }^{4}$ Etherington-Smith minute, 8.12.1951, FO 371/94986.

${ }^{5}$ Ibid.

${ }^{6}$ Ibid.; Stevens to FO, 1.2.1952, Annual Report on Sweden for 1951, FO 371/100930.
} 
achieved, there was little chance of successfully defending Scandinavia. ${ }^{1}$ The problem was how to find the balance between the operational and strategic requirements of the military and the political requirements set out by the Swedish government's publicly proclaimed policy of nonalignment aiming at neutrality in war. Where was the limit that could be crossed only at the expense of the credibility of Sweden's present foreign policy?

Sweden's open membership of NATO was out of the question. 'A change in the composition of the Swedish Government had made Sweden a good deal more reluctant to enter into any form or association with the Western European Powers', the Defence Committee was informed. ${ }^{2}$ Swedish NATO-membership was considered to be unnecessarily provocative to the Soviet Union, but Sweden's determined policy of remaining outside military alliances made this in any case impossible. ${ }^{3}$ The British Labour government had put no pressure on the Swedish government to change their official policy, and the FO officials suggested that this policy should be continued by the new government. In this respect, the memorandum served a negative purpose: to discourage any tendencies to start an American-style campaign against Swedish neutrality that might rise in the Conservative government. ${ }^{4}$ Also the importance of the previous government's policy of supplying Sweden with the armaments it needed, subject only to previous NATO and Commonwealth commitments, was highlighted. ${ }^{5}$

Since the likelihood of the Swedish government entering an official but secret defence agreement was remote, the only way to coordinate defence plans was 'by some informal

' FO draft memorandum 'Swedish Defence', undated (February 1952), FO 371/100946. This longer version of the memorandum presented by Eden for Cabinet contained a fuller elaboration of the FO views. See also Had there been a war..., 153 - 154.

${ }^{2}$ Defence Committee minutes, 19.3.1952 D(52)2, FO 371/100945.

${ }^{3}$ Eden memorandum, 'Swedish Defence', 6.3.1952, C(52)65, FO 371/100946.

${ }^{4}$ Mason to Stevens, 17.4.1952, F0 371/100946.

${ }^{5}$ FO draft memorandum, 'Swedish Defence', undated (February 1952), FO 371/100946. 
arrangement with Sweden'. 'There was, however, a chance of maintaining and developing existing Service contacts with the Swedes in the hope that this might lead to a direct defence connection between Sweden and the United Kingdom'. ${ }^{2}$ This should be arranged through service channels, with the tacit consent of the governments. It was thought that in the absence of a firm defence agreement, an informal arrangement 'might cover the main requirements of the West, in any case, it is almost certainly the best we can hope for in present circumstances' ${ }^{3}$ The chief of the Imperial General Staff confirmed that 'three British Officers had already left for Sweden to develop these contacts with the Swedish Service Chiefs'. ${ }^{4}$ According to this solution, both governments would leave the handling of the problem mostly to their defence chiefs, and the Swedish government would turn a blind eye to their activities.

To achieve this, the highest secrecy was needed. The tacit consent of the Swedish government would have to be secured. The FO advised strongly against proceeding along with some of those Swedish military commanders who were willing to develop planning contacts with the West without the knowledge of their government. If such an arrangement became known to the Swedish government, this might do serious harm to Britain's relations with Sweden as whole. ${ }^{5}$ 'The incident could be exploited in Sweden to discredit the whole idea of co-operation with the West and the work of recent years, which seems to be slowly bearing fruit, would be undone. We should hardly be justified in taking such a risk' ${ }^{6}$ Service level cooperation could be developed as far as possible, but when the point of actually taking the step to coordinate defence plans, ministerial acceptance would be needed from Sweden. In this respect, the FO was also anxious to

\footnotetext{
${ }^{1}$ Eden memorandum, 'Swedish Defence', 6.3.1952, C(52)65, FO 371/100946.

${ }^{2}$ Minutes of Defence Committee meeting, 19.3.1952, D(52)2nd mtg., FO 371/100945.

${ }^{3}$ FO draft brief, 'Swedish Defence', undated (February 1952), FO 371/100946.

${ }^{4}$ Minutes of Defence Committee meeting, 19.3.1952, D(52)2nd mtg., FO 371/100945.

${ }^{5}$ Eden memorandum, 'Swedish Defence', 6.3.1951, C(52)65, FO 371/100946.

${ }^{6}$ FO draft memorandum, 'Swedish Defence', undated (February 1952), FO 371/100946.
} 
retain control over the activities of the British military.

Nevertheless, what this meant in practice was that the actual work would be done by the military with relatively free hands, but that the results of their work would be ultimately subjected to political control and decisions. This meant that staff work could go as far as possible to prepare the technical ground for a political decision to integrate Sweden to NATO as rapidly as possible in some future crisis. Then the final decisions on the highest political level would be crucial. Sweden, of course, could choose neutrality (if not attacked and if the Soviet Union respected this) or alignment, but if it did choose alignment, all the necessary preparations would have been made.

How then should the regular contact on the service level be organised? The options were a direct bilateral Anglo-Swedish link, Sweden's link with NATO (Supreme Headquarters Allied Powers Europe, SHAPE or Allied Forces Northern Europe, AFNE) or using the Norwegian and Danish defence staffs as intermediaries. From the point of view of SHAPE's strategic planning, the direct link with NATO was the most advisable, but for security reasons it was also the most difficult option. It involved a multilateral alliance, and information about Sweden's position would leak out. From the political and practical point of view, links with the other Scandinavian countries would be the easiest option. It would be relatively easy for the Swedes to utilise the contacts they already had. Politically, interaction between the representatives of small states would also arise less suspicion.

Nevertheless, from the overall security point of view a bilateral link with Britain was considered the best option. A link with Britain would also be more effective in actually integrating Sweden's defences with those of the West, as Britain was more centrally placed in Western defence than were the two small Scandinavian countries. Contacts with the British would lead the Swedes close to the core of Western defence planning and decision-making. In the event of using a regular Anglo-Swedish link, the role of NATO 
would have to be adjusted. ${ }^{1}$ But in the last resort, it was for the Swedes to decide what form the regular contacts should take.

The FO advised against taking any fresh initiatives on the political level, as Sweden's determination to follow a nonaligned policy seemed at least as strong as ever. Hence, the policy agreed by the Cabinet was to 'mainly confine ourselves to maintaining and developing existing Service contacts with the Swedes'. A direct Anglo-Swedish link was the immediate object, but an option of developing Sweden's contacts with NATO, possibly through the Norwegians or Danes, was also kept open. ${ }^{2}$

One of the purposes of the Cabinet paper was to clarify the situation to the British services. While giving the soldiers a relatively free hand at the practical level, the FO was anxious to ensure that the service representatives would not go too far in their own discussions with the Swedish military without the necessary political authorisation. The ultimate say was explicitly reserved to the FO and political decisionmakers, if any of the contacts with the Swedes led to definite commitments. The paper was also shown to the State Department in Washington. ${ }^{3}$ The Americans agreed that the tactics adopted by the British were the best. They actually now intended to proceed along the same lines themselves, but were more doubtful whether the Swedes would be any more forthcoming than they had been in the past. As an indication of the still embryonic stage of direct US involvement in contacts with the Swedes, the State Department saw in Sweden 'less willingness now than at the time of the outbreak of the Korean War' to cooperate on questions of defence. ${ }^{4}$

The policy adopted by the new government was in line with the general approach that

\footnotetext{
${ }^{1}$ Eden memorandum, 'Swedish Defence', 6.3.1952, C(52)65, FO 371/100946.

${ }^{2}$ Ibid.

3 Eden to Sir Oliver Franks, 22.3.1952; B. A. B. Burrows (Washington) to Hohler, 27.5.1952, FO 371/100946.

${ }^{4}$ Burrows to Hohler, 27.5.1952, FO 371/100946.
} 
had been adopted in Britain since the end of the war towards the problem of bringing Sweden gradually into closer cooperation with the West. As no advances were anticipated on the political plane, Sweden's links with the West were handled on a lower level, pragmatically and often informally. This involved first and foremost technical military and economic cooperation, and Sweden's membership and contacts with the different multilateral organisations that had emerged since the war. In providing Sweden with these links, and despite the ascendancy of the US, Britain still had and was willing to have a central role. But despite the fact that the rules of the game were now defined by the new government in London, the game itself had only just started. Two big questions remained: How far the Swedes would in the end agree to coordinate their defences with the West? And what would the Americans think of all this? With Eisenhower's arrival as SACEUR in Paris in January 1951, the British were no longer the only party which had elaborate views over Scandinavian strategy and defence. To keep the different parties and organisations in step with each other was as much a challenge for the British as the careful coaxing of the Swedes out of their shell of neutrality. 


\section{DEFINING SWEDEN'S POSITION IN WESTERN DEFENCE, 1952-54}

In 1951 it had seemed that Sweden was gravitating towards the West. This process, that began during Arthur Henderson's visit to Sweden in January 1951 and gained momentum with Allan Vougt's memorandum during the spring, had been abruptly halted by Östen Undén in August 1951. After a government reshuffle in September, the Swedish foreign minister's control over his more pro-Western colleagues and officials was strengthened. Disappointed by these developments, the British were again more sceptical whether there would be any change in Sweden's position. In the Cabinet memorandum of March 1952, Labour's basic policy line was confirmed by the new government. No change was necessary in British attitude towards Swedish neutrality policy, and the main thrust was invested on developments on the lower plane, between service authorities. Political authority was nevertheless reserved to the FO, if contacts at the service level did lead into anything more definite. But how well was the problem of 1949, that of the strategic and political division of Scandinavia, solved? What was actually achieved on the lower plane? What about changes in US policy? What was Britain's role in the whole process of defining Sweden's relationship with the emerging military organisation in the West? The last question points towards Britain's role as the US' most important military ally in Europe and to its role in the process of creating the organisational structure of Western defence in the early 1950 s.

\section{Changes in US policy}

After the Norwegian and Danish decision to participate in the Atlantic alliance in 1949, the US took a less active stance in trying to convince the Swedes to abandon their neutrality policy. With bases in Greenland and Iceland secured, the US military had their 
minimum requirements fulfilled, unlike their colleagues in London who saw the potential dangers that a security quarantee to Norway and Denmark involved without the means to back it up effectively. ${ }^{1}$ Dean Acheson as the new secretary of state was also less keen to embark upon an open political campaign against neutrality than some of his more hawkish advisors, and in late $1950 \mathrm{~W}$. Walton Butterworth, a more moderate ambassador than Matthews had been, was sent to Stockholm.

The new US ambassador was in general less prone to criticise Sweden's neutrality policy. ${ }^{2}$ This did not, however, mean that the US-Swedish relationship was freed from problems. As the basic policy line still was, as it was outlined in NSC 28/1 from September 1948, that Sweden should eventually abandon its neutrality and it should be influenced to do so, problems existed on various levels. An important practical dimension of these problems was the restrictive attitude to exports of US high technology to the Swedish defence forces or the overall reluctance to support neutral Sweden to build up its strength as a part of the regional settlement. At the outbreak of the Korean war the general atmosphere still remained sour on the political level and was hardly conducive to further cooperation. Supreme Commander Swedlund complained about the ignorance of senior US military authorities in Scandinavian defence issues. ${ }^{3}$ If neutrality, or neutralism was detested in principle in the US, the impact of MacArthyism during the Korean war, the perceived internal contradictions in the American society and the aggressiveness of American capitalism also created an unfavourable image in Sweden of the US. ${ }^{4}$ The more progressive elements in the Swedish society held criticial views of the US and not just the Soviet Union, which was especially relevant to the ruling social

\footnotetext{
${ }^{1}$ National Security Council report, 'The Military Implications to the United States of a Scandinavian Pact', 3.2.1949, NSC 28/2, President secretary's files, Papers of Harry S. Truman, Harry S. Truman Library, Independence, Mo., copy in Vol. 13, NPCA.

${ }^{2}$ Butterworth to SD, 20.12.1951, SD, 758.00/12-2051, NA, copy in Vol. 13, NPCA.

${ }^{3}$ Swedlund's diary, 11.10.1951.

${ }^{4}$ State Department policy statement, 'Sweden', 15.8.1949, copy in Vol. 19, NPCA.
} 
democrats when considering their electorate and rank and file support.

Set against this background, when it came to confidential contacts with the Swedish services, as long as the Americans appeared as relatively inexperienced and occasionally hard-handed in their dealings with Scandinavian national sensitivities, the British had no particular wish to cooperate with them more than was necessary. Their policies and actions had been different in the past, and although the two embassies in Stockholm were in close contact, there remained a degree of tension resulting from the previous clashes of policy. The disputes in 1948-50 over armaments deliveries to Sweden were still fresh in their minds. Nevertheless, the situation, where the British only told the Americans what was absolutely necessary and nothing more, was potentially very problematic. The biggest fear was that the Americans would, in their eagerness, put pressure on the Swedes do something that would undo the progress achieved this far. There was a strong need for better coordination of British and US policies, but in the British view this would require the Americans to adopt a more positive attitude towards officially non-aligned Sweden.

Changes were nevertheless underway and steady progress was made in 1951 over the question of technological support to Swedish armed forces. In May that year an export licence was finally, after years of stalling, granted for a very important order of American Bendix-radar to Sweden. ${ }^{1}$ Contacts among military representatives were also becoming more fruitful, and the Swedes gave Colonel Bernt Balchen, the Norwegian born special assistant on Arctic affairs to the secretary of the US Air Force, 'highly classified information ... with regard to certain estimates of capabilities', thus bringing both the US and British staffs more on a par with each other as to information about

\footnotetext{
${ }^{1}$ Ingemar Dörfer, 'Swedish Dependence on Western Military Technology during the Cold War', unpublished paper presented at the conference, 'The Nordic Countries in the Shadow of the Cold War', Danish Institute of International Affairs, Copenhagen 5-7 March 1998.
} 
Swedish defence. ${ }^{1}$ The influence of a group of less hawkish State Department officials, who had already in 1948-49 favoured siding with the British approach to Sweden, also was in the rise, despite the tendency of the Swedish government 'periodically to dig in its toes in effort to restore the balance' against the 'gravitational pull toward West' that had increased during $1951 .{ }^{2}$ In late December 1951 positive news from the US viewpoint was the breakthrough in the protracted negotiations over Sweden's participation in the US driven COCOM embargo of strategic goods to Eastern Europe and the Soviet Union. The agreement that was then reached put Sweden on an equal footing with NATO countries in this respect, and if not becoming a member of the COCOM itself, its trade policy of strategic goods became equivalent to that of the member countries. ${ }^{3}$ This opened the possibility of relaxing US trade of strategic goods to Sweden as well. All these developments finally culminated in a reassessment of US policy towards Sweden in January 1952. In the National Security Council Report 121, the new policy formulation towards Swedish neutrality was:

Although on balance, and primarily because of the advantage to the organization of Scandinavian defense, it would be to our interest to have Sweden in NATO, we must for the predictable future accept as a political fact Sweden's policy of avoiding great power military alliances. ${ }^{4}$

This new formulation finally and decisively brought the two Western powers in step with

\footnotetext{
${ }^{1}$ Edward T. Dickinson (Vice Chairman, National Security Resources Board) memorandum, 29.5.1952, Bernt Balchen Papers, Manuscript Division, Library of Congress, copy in Vol. 20, NPCA.

${ }^{2}$ An example of a less hawkish policy was outlined in a State Department policy statement 'Sweden', 15.8.1949, copy in Vol. 19, NPCA. Butterworth to Acheson, 28.12.1951, SD, 758.00(W)/12-2851, NA, copy in Vol. 13, NPCA.

${ }^{3}$ Butterworth to Acheson, 28.12.1951, SD, 758.00(W)/12-2851, NA, copy in Vol. 13, NPCA.

${ }^{4}$ National Security Council report 'The position of the United States with respect to Scandinavia and Finland', NSC 121, 8.1.1952, printed in Om kriget kommit... Bilagor, 111 116.
} 
each other. If occasional problems still existed on the ground, the fundamental problem of how to integrate the Americans in such a way to the military and economic consolidation of the region that was also acceptable to the Swedes themselves, was finally solved. As a final touch to the improvement of US-Swedish relations, Erlander made a visit to the US in the spring 1952. On 30 June and 1 July 1952 an agreement was reached on the terms of Swedish purchases of military equipment, materials and services from the US. ${ }^{1}$ This followed a presidential decision in February 1952 which ended the period of an informal American arms embargo of Sweden. In actual arms trade itself the British nevertheless dominated the market until late $1950 \mathrm{~s}^{2}$

The new situation influenced British policy in two main ways. On the one hand, the British could continue their own attempts to develop service level contacts and their considerable arms exports to Sweden free from risking political problems with the US. On the other hand, however, the way in which the Americans became more and more involved in the region resulting from their growing influence in NATO's northern strategy (North-East Atlantic in particular) and from the modus vivendi with Sweden, the relative significance of Britain was also reduced on the practical level. US-dominated NATO organs took a more central role in developing contacts with the Swedish services, and the British, without their mediating position, were less centrally placed in Sweden's overall linkage to the West. As also the State Department recommended a policy of developing contacts with the Swedish authorities confidentially and without the risk of political complications, and to develop Sweden's capacity to resist military aggression, the need for a special mediating role for the British was considerably reduced. Two main issues, nonetheless had to be solved. How far would the Swedes be willing to go? What would be the roles and relationships of the different bilateral and multilateral

\footnotetext{
${ }^{1}$ Undén to Butterworth, 30.6.1952, RG 330, Box 77; Butterworth to Undén, SD, 758.5MSP/7-352, NA, copies in Vol. 19, NPCA. See further, Had there been a war.., 123.

${ }^{2}$ Ibid.
} 
arrangements and organisations in the handling of the problem?

\section{Channels opened}

Writing to his parents on 9 February 1952 from Stockholm, the new British ambassador described the surprisingly hectic life of the embassy: 'At moments of this kind, the life of an Ambassador is one long series of trivial yet in their way crucial decisions'. ${ }^{1}$ Hence, following the policy laid down in the Cabinet paper of March 1952, which Stevens described 'a rather oracular document' as it did not contain references to the actual substance of military talks with the Swedes, he contacted the new Swedish defence minister in March $1952 .{ }^{2}$ Stevens assured Nilsson that in all service exchanges a close contact would be maintained from the political point of view and that all British service representatives who were in touch with their Swedish opposite numbers would be fully briefed about Sweden's delicate position as regards neutrality. ${ }^{3}$ Hence, Stevens's message was that the Swedish government ministers could rest assured, as the FO and the politically responsible ministers in London kept the activities of the soldiers in check and had the final say in the matter. This was also the message Stevens 'after considerable hemming and hawing' delivered to Butterworth, who suspected British activities could do more harm than good with Sweden. ${ }^{4}$

Meanwhile, positive news was that the Swedish Defence Staff was very carefully

\footnotetext{
' Stevens to F. Bentham and Cordelia Stevens, 9.2.1952, Stevens papers, Churchill College, Cambridge.

${ }^{2}$ Stevens to Mason, 7.8.1952, FO 371/100947.

${ }^{3}$ Record of conversation, Stevens, 28.3.1952, FO 371/100946.

${ }^{4}$ Butterworth to Acheson, 30.4.1952, SD, 758.5/4-3052, NA, copy in Vol. 19, NPCA.
} 
contacting AFNE's headquarters in Oslo. ${ }^{1}$ The head of Section II of the Swedish Defence Staff (Combined Intelligence), Commodore af Klint had in October 1951 informed the British naval attaché, Captain Derek Wyburd in Stockholm that Supreme Commander Swedlund and the chief of the Swedish Defence Staff General Ảkerman were about to establish some form of planning connection with the West, which was understood to mean Admiral Brind's NATO headquarters in Oslo. Vougt had already dropped a hint to that effect earlier. ${ }^{2}$ In further discussions with Brind, Wyburd found out that Brind was anxious to have this kind of connection, but that nothing existed at present. The Norwegians seemed to have more activity with the Swedes, and this seemed to be the right route for cover purposes. Otherwise, Brind favoured a British service attaché link. ${ }^{3}$ Later Wyburd found out from a Norwegian diplomatic source that Brind had instructed the chief of the Norwegian armed forces, General Berg, to arrange contacts between Swedlund and General Omar Bradley, the chief of the US Joint Chiefs of Staff. The anonymous Norwegian knew about it as he had acted as a link between Berg and Swedlund ${ }^{4}$ Hohler at the Northern Department could not believe these contacts had gone very far, and, given the political complications, 'would be horrified' if they had. ${ }^{5}$ Nevertheless, in late 1951 more information of the Swedish Defence Staff's intentions trickled through. The British air attache found out from General Àkerman that the Swedes were also preoccupied with the problem of how service liaison with the West should be organised and how much their government should know about it. It was, according to Ảkerman, up to Swedlund to decide how much the Swedish government

${ }^{1}$ The Northern Regional Planning Group became the operational headquarters of NATO's northern flank as Northern European Command, Allied Forces Northern Europe (AFNE) on 2 April 1951.

${ }^{2}$ Lambert to Etherington-Smith, 18.10.1951, FO 371/94986.

${ }^{3}$ Notes on conversation between Brind and Wyburd, 6.11.1951, FO 371/94986.

${ }^{4}$ Wyburd minute to Stevens, 15.12.1951, FO 371/94986.

${ }^{5}$ Hohler minute, 31.12.1951, FO 371/94986. 
would be in the picture. For the Swedes, the most preferred channel of liaison would be with a NATO authority via the Norwegians. ${ }^{1}$ General Westring, chief of staff of the Swedish air force also told a member of the British embassy in Stockholm that some form of contact with Brind's command in Oslo was keenly sought by the service chiefs, but that the British should take this up on the political level in Stockholm. ${ }^{2}$

The likelihood of this kind of political approach succeeding was very low. Stevens was assured of this in a conversation with Hammarskjöld in December 1951. To Stevens's question about informal defence coordination, Hammarskjöld very clearly stated that 'this was absolutely out of the question'. Hammarskjöld seemed to have firmed up his stance, compared to his earlier statements in September 1951. There was no doubt from where the wind was now blowing in Stockholm, when Hammarskjöld said that 'the Swedish Government considered that it must play the policy of neutrality honestly. It could not try to get the benefits of NATO membership while remaining outside'. ${ }^{3}$ The furthest the Swedes could go would be to coordinate their defences 'autonomously' if allied plans were somehow made known to them. The conversation ended with Hammarskjöld lecturing about 'the more effective use during the last few years of the diplomatic channel as a well attuned instrument for informal communication between Governments', and reiterating the need 'for an honest and consistent policy of neutrality'. ${ }^{4}$ If the Swedes had got cold feet in the previous summer, they were now frozen to the ground.

But soon after the British Cabinet had approved Eden's guidelines in dealing with Sweden, new encouraging developments occured on the service level. In April 1952

\footnotetext{
${ }^{1}$ Stockholm telegram No. 372 to FO; 6.12.1951, FO 371/94986.

${ }^{2}$ John Bennet (Stockholm) minute, 11.12.1951; Stevens to Eden, 13.12.1951, FO 371/94986.

${ }^{3}$ Stevens's record of conversation with Hammarskjöld, undated, covering letter 20.12.1951, FO $371 / 94986$.

${ }^{4}$ Ibid.
} 
Admiral Strömbäck said that he was determined 'to take every step to safeguard the Forces under his Command', which meant cooperation - technical or strategic - with the British Navy. ${ }^{1}$ Strömbäck told that he was not willing to shoulder the blame for 'having done no thinking ahead during the years of peace' and that 'nothing which had taken place so far between the two navies was known to the politicians ... only a very small number of Swedish naval officers were in the picture themselves' ${ }^{2}$ The British understood this as meaning technical, not strategic, cooperation. ${ }^{3}$ In view of the deadlock on the political level, it was encouraging, nonetheless.

The long awaited opening from the Swedish side soon came. As had been anticipated in late 1951, in early May 1952, British representatives in Stockholm were informed by 'a reliable but delicate source' (commodore af Klint) that the Swedish Defence Staff had finally taken the step to establish 'some form of planning contact' with NATO's Northern European Command through the Norwegian and Danish defence staffs. ${ }^{4}$ Commodore af Klint from the Swedish Defence Staff also wrote confidentially to Rear-Admiral A. W. Buzzard (director of naval intelligence) to the same effect. ${ }^{5}$ The aim was to establish a channel for the exchange of planning information. Indications were 'that a decision to this effect, while remaining a closely guarded secret, has been taken at the highest level and has received the approval of the Swedish Cabinet'. ${ }^{6}$ This also implied, that the Swedes were now more interested in the link with NATO, as opposed to bilateral arrangements. This division of labour suited the British quite well: NATO would take care of the planning side, and the existing Anglo-Swedish contacts of the technical and

1 Record of Conversation, Commander J.F.R. Crews (Stockholm), 7.4.1952, FO 371/100946.

${ }^{2}$ Ibid.

${ }^{3}$ Stevens to Mason, 12.4.1952, FO 371/100946; Faber minute, 2.5.1952, FO 371/100946.

${ }^{4}$ Stevens to Eden, 6.5.1952, FO 371/100946.

${ }^{5}$ Etherington-Smith minute, 20.5.1952, FO 371/100946.

${ }^{6}$ Ibid. 
intelligence side. ${ }^{1}$

After the setbacks of the latter half of 1951, this development aroused new hopes that the problem of Sweden's integration to Scandinavian and Western defence could finally be solved. In the FO the prospects a channel between Sweden and AFNE being opened was considered 'a very important development and may radically alter the whole strategic picture'. ${ }^{2}$ In June 1952 Brind himself confirmed that the Swedish Defence Staff had established a planning link with his headquarters through the Danes and Norwegians. The link was now operational and in use, but actual work had not progressed very far. ${ }^{3}$ The new arrangements were not meant to interrupt or diminish existing Anglo-Swedish intelligence cooperation. ${ }^{4}$ That this cooperation was flourishing was proved by the fact that the head of the British Air Intelligence, Air Vice-Marshal Fressanges visited Stockholm in late June 1952 'to compare notes on intelligence about Soviet Russia' without the knowledge or approval of either the Swedish Ministry of Defence or the Foreign Ministry. ${ }^{5}$ In early August Air Chief Marshal Cochrane (second in command in the RAF) visited Stockholm with very short notice and wished to see Nordenskiöld or Westring for 'private discussion', but in the end only met General Jacobsson socially as the two were on holiday. ${ }^{6}$ These visits were all the more significant since the Soviet Union had just shot down two Swedish aircraft (one reconnaissance, one rescue) over the Baltic with the loss of eight lives. ${ }^{7}$

The FO insisted that these kind of exchanges should be accepted politically in London

\footnotetext{
' Faber minute, 15.5.1952, FO 371/100946.

${ }^{2}$ Etherington-Smith minute, 20.5.1952, FO 371/100946.

${ }^{3}$ Wright to Eden, 23.6.1952, FO 371/100946.

${ }^{4}$ Ibid.

${ }^{5}$ Stevens to Mason, 3.7.1952, FO 371/100946.

${ }^{6}$ Stevens to Mason, 6.8.1952, FO 371/100947.

${ }^{7}$ A detailed, if probably not the last account of the the so called Catalina-affair of June 1952 was published by the Swedish Foreign Ministry in 1992. Nedskjutningen av DC 3-an i juni 1952. Rapport frän DC 3-utredningen (Stockholm: Utrikesdepartementet, Ds 1992:5, 1992).
} 
before they took place, rather than being informed afterwards. ${ }^{1}$ In the present politically delicate situation, the FO wanted to be in control as far as possible. Strang subsequently secured the approval of the service departments that any future visits by senior officers formal or informal - to Sweden would have to be first cleared in the FO. ${ }^{2}$

In October 1952 the director of naval intelligence, Admiral Buzzard, who was probably the most centrally placed British officer in the dealings with the Swedes, paid a visit to Stockholm, when detailed and thorough discussions were held with the Swedish authorities. As a result of these talks, he could report that the Swedes now saw the general Soviet threat 'in much the same way as Her Majesty's Government, and that they accept, both politically and militarily, the basic assumption that Sweden is bound to be attacked in any future war' ${ }^{3}$ In British eyes this made the whole concept of Sweden's successful neutrality in a future war obsolete. In return, an officer from the Swedish Joint Intelligence Section visited London in November 1952, when the discussions were continued. Intelligence contacts with the Swedish navy and air force were reported to be developing satisfactorily and without political complications. ${ }^{4}$

From then on, with the FO's political blessing, visits of this kind and exchanges of information continued. As the understanding in London was that service level cooperation had the tacit consent of the Swedish government, this cooperation became a central part of a concerted policy to integrate Sweden as far as possible to Western defence, not politically but technically and at the lower level of operational planning. Work was also started to begin similar exchanges with army officers. The Swedes stressed the need for secrecy and not even the Americans or Canadians were to be informed of what passed

\footnotetext{
${ }^{1}$ Ibid.

${ }^{2}$ Strang to Slessor (RAF), 26.8.1952 (also addressed to chief of Imperial General Staff \& first sea lord), FO 371/100947.

${ }^{3}$ Eden to Stevens, 10.12.1952, FO 371/100947.

${ }^{4}$ Stevens to Eden, 29.12.1952; Faber minute, 3.1.1953, FO 371/100947.
} 
between them and the British. ${ }^{1}$ The FO continued to emphasise that all visits should be accepted by 'the political arm' of the Swedish Government. ${ }^{2}$ As service contacts were still considered difficult politically it was hoped that no serious trouble would be aroused by the activities of the Swedish military.

In March 1953, the news that the Swedes had opened a channel to AFNE in 1952 was coupled with information that actual practical cooperation had also begun. Stevens learned that it was planned that the British General Sir Robert Mansergh, who would soon be succeeding Brind as AFNE's commander, was to go on a private visit to Sweden. Mansergh would go to meet General Åkerman, the Swedish chief of Defence Staff. The purpose of the visit was to discuss how the contacts with military planners on both sides should be organised. Following the policy set by the Cabinet in March 1952, Stevens contacted Ȧkerman and enquired whether the Swedish Defence and Foreign Ministries were aware of the visit. ${ }^{3}$ Àkerman confirmed that he had 'mentioned the matter in broad terms to Hammarskjöld', but was 'somewhat nervous lest news of it should leak and the matter be taken up by the communist propaganda machine' ${ }^{4}$ General Swedlund would nevertheless shortly inform the defence minister. It was unlikely that Undén would be informed. Stevens thought that this should not bring undue complications, as the directly politically responsible cabinet minister and Deputy Foreign Minister Hammarskjöld would know what was happening. The FO agreed that 'adequate precautions' had been taken to obtain political clearance. ${ }^{5}$ In the end the visit was first postponed until summer 1953 and then postponed indefinitely in order to avoid

\footnotetext{
${ }^{1}$ Stevens to Eden, 29.12.1952, FO 371/100946.

${ }^{2}$ D. P. Reilly to Major-General A. C. Shortt (WO), 30.1.1953, FO 371/100947.

${ }^{3}$ Stevens to Eden, 5.3.1953, FO 371/106635.

${ }^{4}$ Ibid.

${ }^{5}$ Hohler minute, 12.3.1953, FO 371/106635.
} 
suspicions. ${ }^{1}$ Instead of direct conversations between Mansergh and the Swedish Defence Staff taking place, the COS had finally completed their studies and revisions of the papers they had prepared after receiving Vougt's memorandum in March 1951. Now, two years later, Stevens suggested that the COS conclusions should be given to the Swedes as well, who were already quite well informed what the British thought as a result of various discussions that had taken place in 1952. It should be given 'semiofficially to various suitably placed persons in the Swedish Government and Services', namely to Swedlund or his deputy, and later to Hammarskjöld and Arne Lundberg (secretary general of Swedish Foreign Ministry). ${ }^{2}$ This was done in April $1953 .{ }^{3}$ By then Hammarskjöld had left the scene to the United Nations, and a vital link between the Swedish and British government in a wide range of issues was lost, and as it seems, never fully recovered.

Hammarskjöld's significance in Anglo-Swedish relations was not confined to the economic sphere, where his support for Uniscan cooperation was particularly significant. Before his departure, Hammarskjöld held an important position in the Swedish governmental machine, and in particular in the grey area where the political and official spheres met. Half civil servant, half politician, he last served as a deputy foreign minister for international economic affairs linking the Foreign Ministry with the economic interests, and in Undén's full confidence serving 'as a kind of antenna for the Swedish Government in the international sphere'.${ }^{4}$ In Hankey's words Hammarskjöld, unlike other Swedish ministers:

1 Stevens to Eden, 12.3.1953, FO 371/106635; Stevens to Hohler, 25.6.1953, FO $371 / 106636$.

${ }^{2}$ Stevens to Eden, 11.3.1953, FO 371/106635.

${ }^{3}$ Fordham to Churchill, 13.4.1953, FO 371/106636.

${ }^{4}$ Hankey's annual political report for 1953, FO 371/111828. 
[D]id not live in a world in which Sweden's alliance free policy was a sibboleth, not permitting of discussion or debate. He analysed it, rationalised it, paid it lip service, was secretly sceptical of its rigid application and did his best - which was by no means inconsiderable - to make it more flexible behind the scenes. ... The Service Chiefs went to him with their problems, were given advice and I suspect ministerial cover for practices which deviated considerably from official orthodoxy. ${ }^{1}$

'In this respect, above all', Hankey continued, 'he is irreplacable; and with his going Swedish foreign policy has withdrawn once more behind its Great Wall where the true faith is expounded and interpreted only by ardent believers." ${ }^{2}$

However, probably reflecting the last of Hammarskjöld's contributions, the Swedish defence chiefs were pleased to tell Stevens in March 1953, that the 'position between the Services and the Swedish Foreign Office was now established on a satisfactory basis'. ${ }^{3}$ On the political side, the Swedish government had now effectively given the services 'a free hand' to arrange for any visits they considered necessary, but had stressed the need to ensure that there was no adverse publicity. Military exchanges would take place with the approval and knowledge of ministers, unlike in 1952, but the services would 'keep the details quiet'. ${ }^{4}$ In effect, this meant that the Swedish government tacitly turned a blind eye to the issue. This would continue as long as the military would not cause trouble. On their part, the defence chiefs would go to considerable lengths in order to coordinate Sweden's defences with the West. ${ }^{5}$ This would be done on regional basis with AFNE, and not with any other NATO organs with wider responsibilities such as SHAPE. ${ }^{6}$

\footnotetext{
' Ibid.

${ }^{2}$ Ibid.

${ }^{3}$ Record of Stevens' conversations with Ảkerman, Swedlund and af Klint, 12.3.1953, FO $371 / 106635$.

${ }^{4}$ Ibid.

${ }^{5}$ Ibid.

${ }^{6}$ COS minutes, 26.3.1953, COS(53)41, FO 371/106635.
} 


\section{Bilateral and multilateral links}

From the British point of view, Sweden's contacts with NATO and with the British services were two separate matters. Nevertheless, the setting up of NATO's Northern Command under Admiral Brind could hardly be ignored, and as was soon seen, Britain's bilateral contacts with Sweden involved Brind's command closely as well. After spring 1951 the British were no longer the only real military power in charge of operational questions about the Northern flank's defences as the Americans were also represented in AFNE. The Americans were in charge of the command's air forces and were also more interested in an increased naval involvement in the Eastern Atlantic. ${ }^{1}$

The British had nothing against Sweden having contacts or opening channels with NATO authorities in principle, but in practice this approach was very problematic. First, from a political viewpoint, the Northern Department was against the idea of prematurely, and without necessary political authorisation in Sweden, establishing planning links between the Swedish Defence Staff and NATO's Northern Command. ${ }^{2}$ Even if this was highly necessary from the strategic point of view, 'we have ourselves always felt sure that it would be impossible to devise any really effective arrangement which was not known to, and approved by the Swedish Government'. ${ }^{3}$ As seen from the Northern Department, the Swedish military had a long record of exaggerating the extent to which Sweden could enter defence cooperation with the West and 'always toed the line when the Government asserted itself' ${ }^{4}$ If the British became involved in such a scheme that would be arranged behind the backs of the Swedish ministers, it could lead to wider

\footnotetext{
${ }^{1}$ Archer, Uncertain Trust, 18 - 19; Mats Berdal, Forging a maritime alliance. Norway and the evolution of American Maritime Strategy (Oslo: Institute for Defence Studies, 1993), 13 - 19. See further Berdal, The United States, Norway and the Cold War.

${ }^{2}$ Hohler minute, 10.12.1951, FO 371/94986.

${ }^{3}$ Ibid.

${ }^{4}$ Etherington-Smith minute, 28.12.1951, FO 371/94986.
} 
political complications in Anglo-Swedish relations. It could also lead to a 'risk of a political crisis in Sweden, prejudicial to those senior officers who were most friendly to us and strengthening the political elements which favour a neutralist policy'. ${ }^{1}$ Even if willing to grant the military a relatively free hand on the ground, the questions of political authority and responsibility were of such a nature that the FO wanted to retain its steering role. That was a lot easier to achieve with the COS at home than with multilateral NATO organs.

Second, Vougt's memorandum had revealed such shortcomings in the capabilities of the Swedish armed forces, that the most pressing problems did not necessarily arise from planning, but from the present state of Swedish defence as such. ${ }^{2}$ If the Swedish armed forces could not offer any real resistance against the Soviets, a planning link with NATO seemed a secondary problem. Third, in December 1951, i.e. before NSC 121, the understanding in the FO was that also SHAPE did not 'at present approve of the establishment of such contacts with the Swedes'. ${ }^{3}$ Fourth, the involvement of NATO at such an early stage would lead to a need to inform other NATO powers, possibly all of them. This would considerably increase the dangers of leaks. If Brind was to keep the information about contacts with the Swedes to himself, he would risk serious trouble inside the organisation. ${ }^{4}$ Another problem was whether or not to give active help to the Swedish defence chiefs in establishing contacts with Brind's Command. The advice from the Northern Department was that the Swedish defence chiefs should do the running, if they were genuinely willing to go ahead. The best the British could do at this stage was to keep the door open, but not to take decisions one way or another. Cooperation should go on as agreed on the bilateral Anglo-Swedish level.

\footnotetext{
${ }^{1}$ Hohler minute, 15.12.1951, FO 371/94986.

${ }^{2}$ Etherington-Smith minute, 8.12.1951, FO 371/94986.

${ }^{3}$ Ibid.

${ }^{4}$ Etherington-Smith to Lambert, 10.12.1951, FO 371/94986.
} 
The COS agreed with the FO's recommendation of keeping SHAPE out of the picture in December 1951. Nevertheless if anything new came up, Lord Montgomery should keep Eisenhower informed of the situation for 'his personal and exclusive information'. ${ }^{1}$ In January 1952 Mason confirmed the FO's view that an informal link between Sweden and NATO should not be pursued at present. $^{2}$ There was also no particular wish at this stage to proceed without ministerial agreement from Stockholm, and the political atmosphere there surrounding defence cooperation was described as negative. ${ }^{3}$

But when careful steps were nonetheless taken in 1952 to facilitiate coordination of Swedish defence planning with NATO, the problem of the extent of Anglo-American cooperation became acute. Anticipating changes in US policy, Walton Butterworth had already taken a less antagonistic approach towards the Swedes compared to his predecessor, Freeman Matthews. He had 'exercised more or less successfully a restraining influence both on the State Department and on his own staff, both of whom need it', the British ambassador wrote in the summer $1952 .{ }^{4}$ But despite NSC 121, the State Department still, in Stevens's view, appeared occasionally to instruct Butterworth 'to get tough with the Swedes', and his staff was prone to press the Swedes more than the British thought wise or necessary. During the Baltic air incidents in June 1952, 'his Service Attachés rang up the Swedish defence staff almost hourly', but this had been stopped by Butterworth. ${ }^{5}$ This activity had been a good example why the Swedes were not very keen to develop confidential contacts with the Americans, in the way they were willing to do with the British or with the Norwegians and the Danes. In British eyes, the American service attachés, 'few of whom are of high calibre', also seemed to be jealous

\footnotetext{
${ }^{1}$ Lt. Col. Balfour (MoD, COS secretary) to Hohler, 20.12.1951, FO 371/94986.

${ }^{2}$ Mason minute, 1.1.1952, FO 371/100945.

${ }^{3}$ Hohler minute, 3.4.1952, FO 371/100945.

${ }^{4}$ Stevens to Mason, 8.7.1952, FO 371/100946.

${ }^{5}$ Ibid.
} 
of the British attachés' excellent relations with the Swedish services. ${ }^{1}$

The very delicate political situation surrounding the military exchanges needed some careful handling. The Americans were keen to know more, and were wondering what the British were up to. 'They cannot be expected to accept very readily the thesis that the Swedes prefer working bilaterally with us and that the field should therefore be left clear to us', Stevens wrote. ${ }^{2}$ In any case, the British were no longer in the central but solitary position they had been, as NATO's Northern Regional Command was now brought into the picture as well. Only as regards intelligence, Stevens described the situation remaining on the same bilateral Anglo-Swedish basis as before.

If the Americans in Stockholm were let into the picture, especially regarding the links between the Swedish Defence Staff and AFNE, it could be hoped that Butterworth would instruct his service attachés to lay off pressing the Swedes for information altogether. This would make the situation a lot easier to handle, especially on the intelligence side. But if the Americans were also told about the British intelligence contacts, it might prejudice their continuation. The suggestion was that the American ambassador - and the Canadian minister as well - should be informed confidentially and for their own information that the contact with AFNE existed, but nothing more should be said about the intelligence side. ${ }^{3}$

Informing the Americans would have had definite advantages in easing the tensions that existed in Stockholm. It would also have been in line with the wishes of the British embassy in Washington which wanted to keep in close touch with the US Government. The Americans were bound to learn about the link with AFNE sooner or later, and a failure of the British to keep them informed might have a very unfortunate effect and revive suspicions which had probably never been entirely eliminated in the State

\footnotetext{
${ }^{1}$ Ibid.

${ }^{2}$ Stevens to Mason, 8.7.1952, FO 371/100946.

${ }^{3}$ Ibid.
} 
Department 'that we have some special understanding with the Swedes and have purposely left the Americans in the dark'. ${ }^{1}$ The downside was that the Swedes had informed the British in strict confidence and it might not be advisable to extend the number of people who knew about the present situation. In the end Strang and Makins decided that it was not for the British to pass around this information as the Americans would know what they needed to know from their own sources. ${ }^{2}$

The issue then rested on the bilateral basis it had been before. Anglo-American cooperation was lowered to its absolute minimum mainly for security reasons. This, conveniently, also strengthened Britain's position with the Swedes as a distinctive and independent actor, and not just a message-boy of the Americans. If security mattered, so did prestige, especially when there was deficiency in both. What contacts remained, probably only increased mutual suspicions. A student of the problematic surrounding Sweden's position in the early cold war needs constant reminding that the US and Britain had only recently formed an unprecedented military alliance.

The decision not to inform the US did not allay Stevens' fears that the American element in NATO would not be as well briefed of the political delicacy of the situation as the British were. As the evidence now clearly revealed, it had been the Swedes who had taken the initiative towards AFNE, and this could lead to the wrong political conclusions among people who were not well informed of the general political background. He was afraid that 'some American from Oslo will come rushing over here and let the cat out of the bag', or 'Americans in Washington who are not politically attuned will be in solitary possession of the secret'. ${ }^{3}$ The State Department or Butterworth in Stockholm could use their restraining influence only if they knew the

\footnotetext{
${ }^{1}$ Hohler minute, 22.7.1952, FO 371/100946.

${ }^{2}$ Strang minutes, 25.7.1952 and 29.7.1952; Makins minute 28.7.1952; Mason to Stevens, 5.8.1952, FO 371/100946.

${ }^{3}$ Stevens to Mason, 7.8.1952, FO 371/100947.
} 
facts.

In the end, Butterworth's recommendations to the State Department in 1952 were more in line with the British policy than they believed. Despite British suspicions, he handled the situation with discretion and stressed the need for a low profile of the Western powers in the solving of the problem. In his view Norway and Denmark were the right defence partners for Sweden. In fact, he advised against any direct involvement of either of the US or Britain, as this would only be counterproductive. ${ }^{1}$ Butterworth's recommendation to direct the main effort to Norwegian-Swedish links and to keep USSwedish or UK-Swedish contacts within certain limits, was even more cautious than the British line. He realised that the 'UK obviously wants to keep its finger in the Swed [sic] pie for prestige reasons, and the foregoing recommendations may, therefore, be inadequate from their point of view'. ${ }^{2}$ That the British would prefer not to leave the contacts entirely in the hands of the Norwegians even on the practical side, was the message implicit in the sentence in Eden's memorandum, which stated that for 'various reasons, including security, we have, however, hitherto considered that it would be best to start by Swedish-United Kingdom discussions'. ${ }^{3}$ This obsession with secrecy in the dealings with the Americans was, paradoxically perhaps, probably also influenced by the defections of the spies Guy Burgess and Donald Maclean to the Soviet Union in 1951. The reputation of the quality of British secrecy was severely damaged in American but also in Swedish eyes. In 1952 the Swedes repeatedly emphasized 'the extreme importance which they attach to keeping the very existence of these exchanges [intelligence] secret from the Americans and the Canadians'. Any signs of further failures and the Swedes

\footnotetext{
${ }^{1}$ Butterworth to Acheson, 30.4.1952, SD, 758.5/4-3052, NA, copy in Vol. 19, NPCA. See further, Had there been a war..., 145.

${ }^{2}$ Butterworth to Acheson, 30.4.1952.

${ }^{3}$ Eden memorandum, 'Swedish Defence', 6.3.1952, C(52)65, FO 371/100946.

${ }^{4}$ Stevens to Eden, 29.12.1952, FO 371/100947.
} 
would turn the tap off completely. The British could not afford to be suspected of leaks, even if the Swedes still preferred to cooperate with them in information exchanges. Bearing in mind the reputation of the scandal-ridden British security services in 1952 , the State Department could only comment on Eden's argument with two words: 'Oh boy'. ${ }^{1}$ But due to a lack of communication on both sides, the British did not know what the US ambassador thought of the situation, and neither did the US ambassador realise the extent the British already were directly involved.

The FO confirmed in August 1952 their previous policy of not taking any action towards the Americans, and that Brind in AFNE was in a central position in this respect. ${ }^{2}$ He could do what he saw fit with his American colleagues. In October 1952 the situation surrounding the mystery of who knew what about Swedish contacts with NATO was somewhat clarified. The circle of the people in the know was larger than the British initially thought. It was clear from the reports from Oslo that the allied air commander and his chief of staff in AFNE, both Americans, were fully informed about the position, but it was likely that they had not passed information to US political channels. Information was more widespread in Norway as well, where also relatively junior officers had a general idea of the Swedish connections. And finally, it was reported that there had been policy discussions in SHAPE. Thus it was clear that the American ambassador in Stockholm would be informed sooner or later. ${ }^{3}$ By November 1952 it was presumed, that the American government was aware of the Swedish-Norwegian link. ${ }^{4}$

In late 1952 information of Sweden's contacts with NATO was proliferating quickly, as by November the Canadians - who had no representative in AFNE - were also aware that the Swedish and the Norwegians were in close touch with each other on NATO

\footnotetext{
${ }^{1}$ Note in the margin of Butterworth to Acheson, 30.4.1952.

${ }^{2}$ Hohler minute, 26.8.1952, FO 371/100947.

${ }^{3}$ Wright to Hohler, 15.10.1952, FO 371/100947.

${ }^{4}$ D. P. Reilly to Major-General A. C. Shortt, 20.11.1952, FO 371/100947.
} 
questions and that the Norwegians had sent a small planning team to Stockholm. ${ }^{1}$ Ironically, the Canadians had been accidentally informed by the British War Office, which routinely forwarded military attachés' reports that had no 'abnormal security grading', to the Canadian and American liaison officers in London. The War Office apologised, but the cat was already out of the bag. ${ }^{2}$

Despite all the attempts to keep the issue a closely guarded secret, and with an accident such as the abovementioned failure to restrict the circulation of the military attachés' highly sensitive reports, it would have been a miracle if the Soviet Union, with their well-developed information networks in the West and in Stockholm, would have not been aware at least in general what was going on. Indirect support for this argument can be found in recent work based on Soviet archives about the Soviet ambassador's searching 'cross examinations' of Swedish ministers in Stockholm in 1951-52 and about the Soviet assessments that in 1951 Sweden's 'political and military cooperation with USA and especially with England was strengthened'. ${ }^{3}$ In Butterworth's view, the Russians were indeed aware that something was going on, but that they 'apparently believe that the extent of present Swed-Nor coop [sic] is greater than it actually is'. ${ }^{4}$

As additional proof of Soviet suspicions, on 31 January 1953 Radio Moscow reported that a secret military agreement had been established between Sweden and the US. Sweden, it alleged, had secretly become a member of the Atlantic alliance and was deceiving both the international and domestic audiences with its official policy of neutrality. The Swedish communists were quick to follow up the accusations from Moscow. Soon after Radio Moscow's broadcast, the Stockholm-based communist paper 'Ny Dag' claimed that Sweden had abandoned its policy of freedom of alliances. The

\footnotetext{
' Stevens to Mason, 23.10.1952; Littlejohn-Cook minute, 30.10.1952, FO 371/100947.

${ }^{2}$ Major-General Shortt to Reilly, 28.11.1952, FO 371/100947.

${ }^{3}$ Petersson, Med Moskvas Ögon, 52 - 61.

${ }^{4}$ Butterworth to Acheson, 30.4.1952.
} 
increase of imports of Western armaments technology to Sweden in 1952, such as jet engines, tanks and radar equipment, were for the communists evidence that there existed a secret defence agreement between Sweden and US. Also the appointment of a Danish military attaché to Stockholm caught the communists' attention. ${ }^{1}$ What other useful purpose, it was pointed out, could a Danish military representative have in Stockholm, than unofficial defence cooperation between Denmark and Sweden? The Swedish Foreign Ministry was quick to issue an official denial that there was any defence agreement between the US and Sweden. ${ }^{2}$ It had no difficulty in countering the claims made by Ny Dag and Radio Moscow. The allegations were not adequately substantiated, and ordinary commercial armaments contracts could not be considered prejudicial to Sweden's policy of neutrality. They were not far off the mark, however, even if the cooperation with Britain - not with the US - was further developed at this stage.

Although there is no direct evidence that the shooting down of the Swedish aircraft over the Baltic in June 1952 was related to Sweden's initiatives with NATO, nevertheless, if the Russians intended to give the Swedes a clear warning, the timing of their action could not have been better. At least this was the interpretation in the FO as to the basic motives of the Soviet actions, even if the final and immediate decisions behind the incident remained a mystery. It seemed as if the Soviet Union had already given up hope that Sweden would maintain its neutrality in a future war. ${ }^{3}$ EtheringtonSmith saw that the chief Soviet aim 'must be to prevent Sweden from co-operating closely with the West before the outbreak of war'. He nevertheless hoped that the Swedes would continue their 'air reconnaissances as before'.

By summer 1953, the way of organising contacts between Sweden and and the

\footnotetext{
${ }^{1}$ Stevens to Eden, 5.2.1953, FO 371/106635.

${ }^{2}$ Ibid.

${ }^{3}$ Littlejohn-Cook minute, 7.7.1952, FO 371/100951.

${ }^{4}$ Etherington-Smith minute, 8.7.1952, FO 371/100951. Emphasis in the original.
} 
Western powers had been laid down. The Swedes preferred to have their contacts first with fellow Scandinavians, then with the British, and only as a last resort directly with NATO officers. Soon afterwards, when NATO's organisation and planning was developed, the US took a more central role bypassing the British. The reasons for the original pecking order were mainly based on concerns of security, but it was evident that the Swedes were more willing to continue their defence cooperation along traditional lines. ${ }^{1}$ It was interesting how the Swedes still stressed the need to keep the Americans out of the picture in 1953, if not much later. In the autumn of 1953, the Swedish air force chiefs made clear that they would not disclose their plans if anything was forwarded to the Americans. It was 'an absolute condition' that the flow of information should be handled through British, and not through American or NATO channels. ${ }^{2}$ Besides secrecy, there were also political reasons for this. If anything leaked, cooperation with Scandinavians or even with the British might look less conspicuous than cooperation with the capitalist, conservative and aggressive America, as that country was often portrayed in Sweden at the time.

Ultimately, with the increase of American interest and involvement in Scandinavian defence during the course of 1950 s, the US and NATO machinery took a more central role. The more central US role became clearly visible in 1953, following the sea change in US attitude towards Sweden. In arranging visits of American senior officers to Stockholm in 1953, the American embassy took a more active role that had been customary in the past. ${ }^{3}$ When General Mansergh's visit to Sweden was cancelled in 1953 , a substitution was soon found in General Carter, the US air force commander in the northern sector, who paid a private visit to Sweden in late March 1953. Carter did not meet Åkerman or Swedlund, but had conversations with General Westring, the chief of

\footnotetext{
${ }^{1}$ Stevens to Wright, 1.7.1953, FO 371/106636.

${ }^{2}$ Hohler minute, 11.9.1953, FO 371/106636.

${ }^{3}$ Stevens to Eden, 12.3.1953, FO 371/106635.
} 
staff of the Swedish air force. ${ }^{1}$ Another indication of the increased US role was Swedlund's suggestion to Butterworth in January 1953, that exchanges of strategic planning information should take place between him and an 'American staff officer conversant with plans for European defense' as 'he [Swedlund] said he felt Sweden now understood and fully appreciated America's constructive policy in Europe and that in turn USA now understood whys and wherefores of Sweden's policy'. ${ }^{2}$ In Butterworth's view it was a significant departure that the Swedes should approach the US directly and did not doubt that Swedlund's suggestion had been cleared in advance on the political level. ${ }^{3}$ Following the policy set out in NSC 121, which among other things advocated increasing interchange of military information with the Swedes, the new Secretary of State John Foster Dulles authorised these exchanges in February 1953, which in the end took place in Frankfurt between Swedish and US representatives from SHAPE. ${ }^{4}$ A similar development, where the British were completely bypassed and informed only afterwards, took place in 1954, when the Swedish Defence Staff, 'apparently with the full knowledge and approval of their government' approached the Standing Group of NATO and 'transmitted to them details of the Swedish armed strength in the respective services, together with a summary of Swedish logistical requirements in the event of war'. ${ }^{5}$ With these developments, and the American officers becoming more active in AFNE in Oslo, the overall practical and political significance of the US increased in dealing with Sweden.

All these were clear signs that the British had to begin to make room for the

\footnotetext{
${ }^{1}$ Statham minute, 7.4.1953, FO 371/106635.

${ }^{2}$ Butterworth to Acheson, 20.1.1953, SD, 758.5/1-2053, NA, copy in Vol. 19, NPCA. Previously Swedlund had spoken for a 'qualified service attaché' to be sent to Stockholm for exchanges. Swedlund's diary, 7.9.1951; 19.10.1951.

${ }^{3}$ Ibid.

${ }^{4}$ Dulles to Butterworth, 17.2.1953, SD, 758.5/1-2053, NA; 25.2.1953, SD, 758.5/2-1853, NA, copies in Vol. 19, NPCA.

${ }^{s}$ Brief for Selwyn Lloyd, 28.6.1954, FO 371/111835.
} 
Americans. But in 1953, the new British commander of AFNE in Oslo, General Mansergh, was still in control over contacts between NATO and Sweden. ${ }^{1}$ Despite increased US involvement, the British COS decided in July 1953 that defence cooperation with Sweden should in the future be developed on the basis of covert national contacts as well. SACEUR agreed with the continuance of a direct Anglo-Swedish link. The Service attachés in Stockholm were the primary means of communication in this scheme. ${ }^{2}$ The British attachés in Stockholm and the NATO officers in Oslo kept their chiefs in London and at SHAPE informed personally and confidentially, but they were largely in charge of the issues at hand themselves. It was agreed, that higher NATO authorities, such as SACEUR, would be informed from time to time by the British COS, if and when any progress was made on the lower level. ${ }^{3}$

\section{Cooperation with limits}

What was the net result of these developments? Was Sweden's place in Scandinavian defence significantly altered from the situation in 1949? What were the implications of these developments to Sweden's policy of neutrality? And finally, what was the British role in this process?

Several assessments were made in Britain in 1953 and 1954 to ascertain how far the problem of 1949 was solved. The most significant of these were the reports by Admiral Buzzard, which were based on a series of conversations held between autumn 1952 and summer 1954 in Scandinavia. The extensive conversations took place 'with most of the Ministers of Defence, Service Chiefs and Senior Intelligence Officers in Stockholm, Oslo

\footnotetext{
${ }^{1}$ Had there been a war..., 158.

${ }^{2}$ Statham minute, 14.7.1953, FO 371/106636.

${ }^{3}$ COS minutes, 15.10.1953, COS(53)111, FO 371/106636.
} 
and Copenhagen, the British Embassy Staffs in these capitals, the N.A.T.O. authorities in Oslo, and Field Marshal Montgomery'.'

In June 1954 the general assessment was that 'the Swedish attitude has moved considerably towards the West, and it is now generally appreciated by the authorities in Sweden that she is almost bound to be attacked in global war, and that once Zealand [in Denmark] is lost, her ultimate fate is sealed'. ${ }^{2}$ Also the Norwegians shared this view regarding Zealand as their own 'first and only sound line of defence against attack from the South and East'. ${ }^{3}$ The only real solution to the problem was to have German divisions take care of the defence of Denmark, but until these materialised, the defence of Zealand remained the weak point of the whole of Scandinavian defence. But if, as it seemed, NATO's central command SHAPE would not support any major concentrations of NATO forces in the defence of Zealand before West German rearmament, who would take care of it? Sweden?

Buzzard's conclusion was that 'in Sweden I found the Swedish military authorities are now entirely in line with the British appreciation of probable Russian strategy in Scandinavia'. This basically meant the following:

(a) That Scandinavia is of prime importance to the Russians in global war because it is the key to the war at sea and the sector in which the Russians are most exposed to Allied atomic attack, and because it closely flanks the Central European front and communications leading to it;

(b) That Sweden constitutes Russia's main problem in Scandinavia because of her great strength compared with Norway and Denmark, her awkward position on the Russian doorstep, her favourable geographical features enabling her forces and supplies to be concealed or sheltered underground, and because Russia can hardly hope to gain Norway from either the North or South without invading Sweden. (c) That the key to Russia's difficult Swedish problem is to grasp Zealand quickly before Sweden becomes involved and brings her formidable air and naval forces

\footnotetext{
${ }^{1}$ Buzzard memorandum, 'Scandinavia', 15.6.1954, FO 371/111346.

${ }^{2}$ Ibid.

${ }^{3}$ Ibid.
} 
into play, and thus:-

(i) Make the Baltic largely secure for the subsequent invasion of Sweden; and

(ii) Deploy the full strength of the Russian Baltic surface and submarine fleets against the vital Swedish supply lines from the West, about $75 \%$ of which must come to the Gothenburg area, or into the Baltic, and $25 \%$ into Trondheim. ${ }^{1}$

To the great satisfaction of the British and NATO planners, Buzzard could make the following conclusion:

The Swedish Service Chiefs were emphatic that they have pointed out to their Government, and convinced at least some of them, that:-

(a) Russia was certain to attack them sooner or later; and

(b) Once Zealand is lost, they have little or no chance of holding out against the Russians for any length of time. ${ }^{2}$

There was thus no doubt about the lines along which the Swedish military was thinking, and that they would 'do their utmost to get their Government to join in the Naval and Air battle for Zealand'. But the government's final decision would still depend on the circumstances. 'The stronger Zealand is, the better the chances of Sweden fighting for it', and the longer Zealand could be kept the bigger the chances were that Russia became involved with Sweden through operations elsewhere. ${ }^{3}$ There were not, however, definite indications whether the Swedes would throw their lot with the West politically. Buzzard could nonetheless observe, that there was no doubt 'that the Swedish attitude generally has moved considerably towards the West since I was in Stockholm eighteen months ago [autumn 1952], and their military potential, already several times that of Norway and Denmark, is developing steadily, in particular in quality'. ${ }^{4}$

\footnotetext{
1 Ibid.

${ }^{2}$ Ibid.

${ }^{3}$ Ibid.

${ }^{4}$ Ibid.
} 
By 1954 the nexus of the problems in Scandinavian defence and the Western requirements from Sweden were located to the defence of the island of Zealand in Denmark. However, as a sign that the general concept of a future war in Europe was changing, and with it any pressures there might be towards Sweden's policy of neutrality, Field Marshal Montgomery made it clear that the need to 'exploit Swedish friendship, strength and geography' was no longer particularly great. ${ }^{1}$ As the mood in 1954 was that there was no immediate danger of war, at least for five years, Montgomery was willing to wait for West German divisions. When these did materialise, the Swedes no longer had the crucial position they previously had in Scandinavian defence. Hence, the dilemma of 1949 , was partially solved by West German divisions, partially with Sweden's cooperation in exchanges of information and in aligning its general planning concepts with NATO. At least from the point of view of British military planners, any pressures that existed towards Swedish neutrality from the strategic point of view for all practical purposes disappeared after West German rearmament in 1954-55. This development was further enchanced by changes in post-Stalinist Soviet foreign policy in the Nordic region, namely Khrushchev's 'peace campaign' and the public U-turn in Soviet attitudes towards neutrality in 1954-55.

On the political level, all these developments confirmed and vindicated the earlier policy of favouring Swedish neutrality policy, with the significant condition that Sweden cooperated with the West in intelligence and service-to-service exchanges. This policy was restated in a FO stock-taking paper on the situation in 1954:

Sweden's accession to N.A.T.O. would be a substantial contribution to the strength of the northern flank. But although the Swedes dislike the Russians and are by culture and background close to the West, their temperament and their experience in the last two wars have convinced them of the wisdom of the

\footnotetext{
${ }^{1}$ Ibid.
} 
traditional Scandinavian policy of neutrality. This they show no signs of abandoning; and although Sweden would almost certainly be involved in any invasion of Scandinavia, it would be folly to press her openly or too hard to throw in her lot with us. We may wish for the day when Swedish public opinion would be prepared for Sweden to enter N.A.T.O., but our present policy must stop well short of an invitation to do so. We must recognise that Swedish acceptance of such an invitation might conceivably provoke the Soviet Union forcibly to incorporate Finland into the Eastern bloc. Instead, we should seek every occasion to encourage closer planning and to extend the present intelligence and Service-to-Service links. To this end we must seek to impress on the Swedes that the battle for Denmark at once becomes the battle for Sweden too. ${ }^{1}$

That Finland would, after all, be dispensable and was not the ultimate motivation behind this policy was clear from the following:

We cannot, however, exclude the possibility that a stage in Western defence planning may be reached when the importance of Sweden's accession to N.A.T.O. becomes so vital that we should be willing to risk Russian counteraction in Finland as the price for it. ${ }^{2}$

During the first years of the 1950s means were found to establish planning contacts and channels for the exchange of information with the Swedes and NATO's Northern Regional Command, AFNE at Oslo. The contacts with NATO were organised with the Norwegians and Danes as intermediaries. Otherwise bilateral contacts continued as before and were further developed between the Swedish Defence Staff in Stockholm and the British service attachés. The British role was especially strong on the technical and intelligence side.

The years 1951-52 was a turning point in this respect. Everything was done under a tight veil of secrecy, and only a limited number of officers and officials were aware of the contacts. As the cooperation was mostly conducted under the cover of personal and

\footnotetext{
' FO memorandum, 'British policy towards Scandinavia', 4.5.1954, FO 371/111337.

${ }^{2}$ Ibid.
} 
informal meetings or technical cooperation, the number of politically responsible ministers involved was kept very low in all countries involved. On the other hand, Sweden's contribution to Western defence was kept strictly to a regional basis, in the defence of Scandinavia. Also, no politically binding commitments were entered into in Britain, Sweden, or in NATO. The closest the British and the Swedes came to reaching a political arrangement was in 1951, was after Henderson's visit to Sweden and Vougt's memorandum. Nothing came of this, and in due course the need for this kind of political agreement diminished in direct proportion with the perceived threat of the Soviet Union in Scandinavia and in inverse proportion with the military strength of NATO and West Germany in particular.

Hence, the defence relationship between Sweden and Britain was not based on mutual promises of substantial military aid in a future war (as in an alliance), but on strategic and technical coordination of defences that aimed for the optimal use of resources in each country. In this respect it resembled the defence relationship of Britain and France before the First World War, when joint staff talks and the 'entente cordiale' of 1904 did not signify binding political commitments, although eventually the countries took the same side in the war. Another parallel could be found in the relationship between Britain and the US before 1941, when defence coordination was extensive but there were no political commitments. Nonetheless, as these preparations became the basis for eventual alliances, it is very likely that the same could have happened with Sweden as well if war came.

However, perhaps the best historical parallels to Sweden's relationship with NATO, Britain and the West in general in the cold war could perhaps be found closer, from Finnish history. The first is the secret military cooperation between Finland and Estonia in the 1930s before the Second World War, which did not lead to actual wartime alliance or even co-belligerency. The second is Finland's relationship with Hitler's Germany in 1940-41, which did lead to co-belligerency. Both cases illustrate the potential and limits 
embodied in this type of cooperation.

As in the Anglo-Swedish case, most of the actual substance of Finland's military talks with the Estonians in the 1930s and the Germans in 1940-41, was of practical technical importance. There were no politically binding commitments. ${ }^{1}$ As Jukka Nevakivi put it in 1984, when assessing the significance of Scandinavian exploratory defence talks of 1946-47: 'Finns if anyone, have experience of agreements concluded at the military level, in the shadow of which even questions of foreign-policy orientation have been solved'.2 The transit agreement made with Nazi Germany in August-September 1940, and the subsequent technical cooperation is a case in point. According to Mauno Jokipii, and with the historian's benefit of hindsight, this step by step process had by February 1941 - four months before operation Barbarossa was launched - reached the point of no return for Finland, whether the political decisionmakers wanted it or not. ${ }^{3}$

As the cold war never turned hot in Europe, we can never assess Sweden's relationship with the Western powers in the same way. The obvious reason why Finland's cooperation with Estonia did not reach a similar point was in the inability of either of the parties to give real security to the other. Again, as neither Sweden's preparations for war nor Britain's and NATO's capabilities for military action in Scandinavia were tested in war, we can never fully answer whether this would have been the case there as well. In this respect, the problem of Sweden's 'real' position between the cold war blocs can never be fully answered, as it is counterfactual.

A peacetime alliance relationship between Sweden and the West was considered politically impossible, but not even necessary, as it was held in London that any future

\footnotetext{
${ }^{1}$ Jari Leskinen, Vaiettu Suomen silta. Suomen ja Viron salainen sotilaallinen yhteistoiminta Neuvostoliiton varalta vuosina 1930-1939 (Helsinki: Finnish Historical Society, 1997).

${ }^{2}$ Nevakivi, 'Scandinavian Talks on Military Cooperation in 1946-1947', 165 - 175.

${ }^{3}$ Mauno Jokipii, Jatkosodan synty. Tutkimuksia Saksan ja Suomen sotilaallisesta yhteistyöstä 1940-41 (Helsinki: Otava, 1987).
} 
war in Europe against the Soviet Union would also involve Sweden. The prospect of Sweden remaining neutral in a future all-out East-West war was considered unlikely in London. In Sweden, some political decisionmakers were more hesitant on this score, but the overwhelming consensus among the military planners was that neutrality policy was indeed a weak shield for Sweden. ${ }^{1}$ Despite more optimistic voices in Sweden on the political level, for the British military planners, the question of Swedish neutrality in a future war became largely academic. For the COS Sweden was strategically, if not politically, an integral part of the West. The main problem was how to organise existing resources in the most effective way. The ghost of April 1940 loomed large.

The role the British played in this search for links between Sweden and the West was pivotal. There was no doubt that only the US possessed the material resources needed for military security in the region in the future, but the British were the party that was initially more active in the practical organisation of the question. The basis for this role lay in the existing good relations between ministers, officials and soldiers that had been forged during the Labour government. Looking back to these developments, Robin Hankey, now as ambassador in Stockholm later wrote:

When I arrived here in 1954, one could still smell some of the sulphurous fumes of the controversy of 1948, when many Swedes, including the then Supreme Commander of the Armed Forces [Helge Jung], wanted their Government to join NATO and when some pressure was exerted in that direction by the Americans. I have made it clear, as my predecessor did also, that Her Majesty's Government accept Sweden's alliance-free policy. ${ }^{2}$

The fact that Britain did not side with the US in putting pressure on Sweden, provided

\footnotetext{
'Swedlund's diary, 12.5.1953; Foreign Policy Committee's minutes, 30.1.1952, A 2, Vol. 6, RA. Recent surveys of Swedish threat perceptions are found in Kent Zetterberg (ed.), Hotet frän Öster. Tre studier om svensk säkerhetspolitik, krigsplanering och strategi $i$ det kalla krigets första fas 1945-1958 (Stockholm: Försvarshögskolan, 1997).

${ }^{2}$ Hankey to Selwyn Lloyd, 12.4.1960, FO 371/152052.
} 
the air of confidentiality and trust that was needed in the sensitive exchanges that were initiated after 1949. Even if the Conservative government lost Labour's finely tuned personal contacts with Swedish ministers, the basic policy line towards Sweden did not change. Sweden remained officially neutral, and this policy was not challenged. It was not even necessary. The practical work beneath the surface displayed enough willingness in Sweden to consider it to be a part of a wider Western front against the potential expansionism by the Soviet Union.

Later in the 1950 s the US was also to take a more active role on the practical side. The net result of the events in 1951-54 was that although no political agreements were reached, the basic structures of Sweden's connection with the Western powers were laid down, both on bilateral basis and on the basis of informal contacts with NATO. Essentially it meant openness in the exchanges of information which could enable coordinated planning on different sides, without necessarily entering binding commitments. If falling short of a actual defence agreement, the minimum requirements of both sides could be fulfilled. If this was the best that the West could get from the Swedes, the British were the first to settle with it. The degree in which this was on the long run accepted in the US as well, was witnessed in the NSC 6006/1 in 1960:

Under the present circumstances, Sweden's membership in NATO is not necessary to Western defence ... [however] ... In the event of Soviet Bloc aggression against Sweden alone, [the US is] prepared to come to the assistance of Sweden as part of a NATO or UN response to the aggression. ${ }^{1}$

That Sweden's integrity in the cold war was now thus unilaterally guaranteed by the US witnessed how far US policy had travelled from the 1948 formulations. But if realpolitik in the end gained the upper hand in Washington, there was as little willingness in the US

\footnotetext{
${ }^{1}$ National Security Council Report, 'U.S. Policy towards Scandinavia (Denmark, Norway and Sweden)', NSC 6006/1, 6.4.1960, printed in Om kriget kommit... Bilagor, 129 - 142.
} 
as there had been in London earlier to declare to all the world that following a policy of neutrality gave such distinctive advantages over open alignment. Neither did neutrality in any way become a popular concept in itself for US policy-makers. In the Swedish case, it served the US realpolitik interests and the regional balance, but as Robin Hankey explained in January 1955: 'neutrality is an attitude which Americans seem congenitally unable to understand'. ${ }^{1}$ This, as was said in the FO stock-taking memorandum of 1954, placed:

a unique and important responsibility on the United Kingdom, with its close ties with both Americans and Scandinavians. It must be our role, played with patience and tact, to promote in the Americans respect for the Scandinavian spirit of independence and consideration for the deep-rooted tradition of neutralism with which the Norwegians and the Danes have made a break; and in the Scandinavians an understanding of the fundamental soundness of American policy and confidence in their capacity to lead the free world.

Despite the confirmation and consolidation of the change in US policy towards Sweden in 1952, when realpolitik won over universalism, the British continued to see themselves, if no longer as an active mediator, at least as a necessary buffer between Sweden and the US, if changes in US policies ever threatened the basic approach to Swedish neutrality that had been consolidated after so much trouble. On leaving Sweden after six years as ambassador, Hankey, whose fingerprints probably more than anyone else's were left on British and subsequently Western policies towards Swedish neutrality in the cold war, summed up the position:

[Sweden] is, to some degree, a barnacle on the bottom of the NATO ship. This particular barnacle may be a separate living entity, but it is only too apparent from a glance at the map that we must want it to have the roughest, toughest and

\footnotetext{
' Hankey to Eden, 'Sweden: Annual Review for 1954', 17.1.1955, FO 371/116861.
} 
most abrasive shell possible. ${ }^{1}$

That Sweden did grow that shell, and could do it without a fear of isolation from the West, was the lasting legacy of British involvement in the early cold war in the Nordic region.

${ }^{1}$ Hankey to Selwyn Lloyd, 12.4.1960, FO 371/152052. 


\section{CONCLUSION}

By 1954 the Nordic countries had weathered the storm of the first phase of the cold war. Norway and Denmark were safely integrated within NATO. Finland, although living in curious coexistence with its bearish neighbour, had managed to keep its social and political institutions intact and remained economically a part of the West. Sweden, militarily nonaligned, shared the same cultural and ideological values with the West. It was also firmly tied within the larger group of Western nations economically and institutionally, in the OEEC, the Council of Europe and with its Scandinavian partners and Britain in Uniscan.

This stabilisation of the region into what has been labelled as the Nordic balance, was due to both internal and external factors. The commitment of the Norwegians to link their country to the Atlantic community was equalled by the Finnish leaders' determination to build their country's postwar relationship with the Soviet Union on a solid, realistic basis of coexistence. Sweden's preference of not openly taking sides in great power disputes was rooted both in tradition and mentalité on the one hand, and on a dispassionate and rational calculation of its own self-interest on the other.

But small states rarely shape their external environment according to their own wishes. Finland's position as an exposed outpost of the Western way of life was to a large extent due to Stalin's hesitations during the last stages of the Second World War about annexing Finland to his empire by force. That Norway and Denmark became members of the Atlantic pact in 1949, and not partners with Sweden in a Scandinavian defence union, was helped by political intervention from the US. Sweden's policy of 'nonalignment in peace aiming at neutrality in war' neither led to international isolation nor serious political problems, and was facilitated by the fact that by 1954 both the US and the Soviet Union had accepted it as a political reality and took no active measures to alter it. 
However, the seemingly calm Nordic balance was not the inevitable result of some pre-determined processes. Nor was its continuance to be taken for granted, as was seen in Finland during renewed tension with the Soviet Union in 1958 and 1961. That the European north remained a sideshow was not the only possible outcome of the cold war. In the broad sweep of the history of the cold war, the politico-strategic management of the Nordic region stands out as one of its rare success stories. Given the global strategic significance of the high north and the Nordic region as a whole - which increased as time went by - all this could have ended differently. But instead of becoming a bitter cold war battleground, the Nordic region was pacified and kept in an approximate power balance.

This thesis has sought to highlight what part British policy played in this. Britain's role was initially that of a relatively independent actor. Britain's need to integrate both American and Swedish resources to stabilise the north into a regional balance within the overall global balance required moderation, preparedness for compromises and persuasion in all directions. This was a way in which Britain could still use its international power, no longer arising from preponderant military or economic strength, but from a long tradition of diplomacy and political involvement, regional expertise, skills of persuasion and negotiation. It also highlighted the significance of compounding or substituting formal and official means of cooperation, such as treaties and alliances, with informal cooperation and channels of communication.

Soon after the war Britain adopted a policy of fostering closer relations with Sweden than had been customary in the past. The pro-German orientation of a certain segment in the Swedish political and military establishment was soon forgotten in the hope that relations would in the future be more cordial. The balance sheet of Swedish wartime neutrality was also considered sympathetically, as it was seen to have contained certain advantages as well as disadvantages. The whole of Scandinavia soon became a part of Bevin's overall policy of developing Britain's relations with its Western European 
neighbours, politically as well as economically. At first, however, the Scandinavians showed a tendency to place themselves between East and West, echoing their previous neutrality policies. This, in contrast with the Benelux countries, subsequently led them all to be more distant from London in the initial postwar period. When cold war tensions were increasing in late 1946 and early 1947, the British aim of keeping Scandinavia close to the West, excluding Finland which was considered to fall in the Soviet sphere, was coupled with an interest in inter-Scandinavian cooperation. It was considered in May-June 1947, after lengthy internal debate in the FO and COS, that Scandinavian defence cooperation, potentially under Swedish leadership and based on some form of neutrality, was in the interest of the West and should be encouraged. This was maintained as British policy until the process towards the Atlantic alliance gained momentum in the spring and summer of 1948 .

The concerns arising from the beginning of the cold war and the economic base of Britain's relationship with Scandinavia and Sweden in particular, were blended in political terms in the emerging institutional structure of Western European economic cooperation. All the basic goals of British policy that were formulated during and immediately after the war, were seen clearly in an operational form when European economic reconstruction gained an institutional, and inevitably a political aspect with the launching of the Marshall plan in the summer of 1947. Besides promising dollars, the US foreign secretary, George $\mathrm{C}$. Marshall provided the British with an additional and a useful way to pull the problematic Swedes in, without the complicating factor of reconciling military nonaligment with further political cooperation. Sweden's participation in the OEEC was considered a distinctive political achievement by the British Labour government. It soon provided the British also with a useful ally in questions of Western European economic cooperation and ultimately integration.

In 1948 attitudes towards Scandinavian defence cooperation based on common 
neutrality hardened somewhat, and the prospect of having Norway and Denmark join the Atlantic alliance changed Britain's political, if not strategic, priorities in the region. But even then, Swedish neutrality and Scandinavian unity which was considered essential in any economic or military arrangements, might be reconciled. This could be done in a system of interlocking security pacts, which was designed in the FO in 1948 to meet the minimum requirements of neutral Sweden, its neighbours and the Western powers. Nonetheless, the 'Hankey plan' never left the drawing board after the Norwegians rebuffed the idea in the autumn of 1948 and it was finally shelved in January 1949. After this failure, a split in Scandinavia between NATO members and a neutral Sweden was very reluctantly accepted in Britain. If the interlocking security pact plan had failed, perhaps something of this kind could be established tacitly?

While questions of possible military cooperation at the service level were being explored in 1949, the Scandinavians were as apprehensive as the British about the economic blockbuilding that began in earnest in the autumn of 1949 with the Finebel proposals and in May 1950 with the announcement of the Schuman plan. Uniscan, as an economically modest response, was a part of Britain's search for allies in questions of Western European cooperation and was intended also to strengthen sterling as an international currency. It was also motivated by a political need to maintain a direct institutional link with nonaligned Sweden, in particular as the cold war seemed in 1950 to be gaining an increasingly economic character. Restrictions in East-West trade, the economic impact of massive rearmament and the possibility of NATO's growing economic functions increased the need to keep Sweden abreast with these developments. Uniscan provided exactly the kind of mechanism of regular consultation that a variety of British interests with Sweden, economic and political, required. This also explains its longevity despite its neglible economic achievements. Uniscan lasted as an active body until the creation of EFTA in 1959-60, and indeed paved the way for it. Hence, it 
deserves a higher profile in any consideration of British policy in the region.

While Sweden's belonging to the West was consolidated along the Anglo-Swedish axis in the OEEC and Uniscan, the Korean war saw the emergence of the pattern in Scandinavia's strategic outlook that enabled the Nordic balance to be interpreted in a positive light in the West. In the end, what mattered was effective cooperation with Sweden if a war ever affected Scandinavia. The lessons from the disastrous improvisations of 1940 were still remembered. If Sweden was not to join NATO or to enter any other defence agreements with the Scandinavians or the Western powers, how would the problem of Scandinavian defence be solved? The answer was twofold: to build up Swedish military capabilities, and to develop planning contacts with service authorities.

What, in the British view, was needed, was practical and technical cooperation to facilitate wartime cooperation as far as possible. This took place mainly between service authorities, by and large with the tacit blessing of political leaders in both Sweden and in Britain, Norway, Denmark and later in the US. In the first stages, the matter was mainly handled on an Anglo-Swedish basis, with links between the Scandinavians as well. The special links with the Swedes also enhanced a role for the British in Scandinavia. Confidential contacts with the Swedes were important not just because they were useful, but because they were a British affair. After the Korean war and with the subsequent growth of direct US and NATO interest as represented by SACEUR, UK representatives took a less leading role.

Despite the covert contacts, exchanges of information and the convergence of defence plans in Sweden and in NATO, Sweden did not become a secret NATO member. No evidence of binding commitments has been found in this research and in that respect it has confirmed the conclusions of the Neutrality Policy Commission. A cut and dry defence scheme, secret or public, would of course have met the major Western 
requirements and have considerably strengthened the resources of the northern flank. But, and here this thesis parts company with the Neutrality Policy Commission, this was not necessarily needed. Any agreement would have meant a mutual pledge of automatic support or co-belligerency in a future war. As the only real threat scenario was a Soviet attack, British military planners, supported by their Swedish colleagues, did not anticipate that Sweden would be able to escape from an attack. In the tense and alarmist atmosphere of the Korean war, they did not think it was possible that an attack on Norway or Denmark would leave Sweden out. However, because the Swedish government retained its ultimate freedom of action in deciding whether or not to join in the battle before attacked, neutrality might always be a possible, if not the most likely scenario. But as long as Sweden's participation alongside NATO forces in a future war was considered as more likely than its neutrality, no definite pledge or agreement was necessarily even needed. If that was the best the British could get from Sweden, they settled for it. Instead of concluding binding agreements in peacetime, the degree of coordination with Sweden could be done in a manner that would enable the existing separate defence plans to be coordinated in a way that aimed at the most effective use of resources in the different countries, if the need for joint action arose. As the defence of Scandinavia could only be considered as a whole against a Soviet threat, the contacts between the military chiefs were valuable in exchanging information, maintaining close consultation and tacitly coordinating defence plans, as far as the latter was possible without entering politically binding commitments. Britain's role in establishing this strategic outlook was very important.

The crux of the matter when dealing with Sweden concerns attitudes towards neutrality as a legitimate option for a small power in great power disputes. In the exceptional conditions of the cold war, neutrality as such was not opposed in postwar British foreign policy. In this sense it fitted well with the pragmatic tradition of British 
foreign policy making. Neutrality was not considered to prevent peacetime cooperation between military authorities. It was left to the neutral itself to draw the line that could not be crossed in these exchanges. The same applied to surrendering national decisionmaking powers to international institutions in other fields, such as economic cooperation. But if neutrality policy was accepted, it was also adapted and adjusted, and effectively contained. A unified, neutral Germany, for example, was completely out of the question even if peacetime neutrality policy seemed to be a legitimate choice for Sweden.

Despite this acceptance of Sweden's official foreign policy line, it was no surprise that problems emerged when Sweden's policy of neutrality conflicted with demands of Britain's other, vital strategic or political interersts. Nevertheless, these problems were sought to be surmounted by informal and subtle means, and not by applying political pressure, as happened in US policy from 1947 onwards. Britain did not wish to and could not isolate a recalcitrant Sweden. The participation of Sweden was considered essential in Scandinavian defence. Sweden was politically an important factor in the ways the cold war affected northern Europe and British interests there. At the same time, Sweden was a useful ally in questions of the institutional structure of European economic cooperation. Also economically, Sweden enjoyed the position of being Britain's most important European trading partner. The multitude of Britain's economic and strategic interests in Sweden all spoke for moderation when it came to formulating responses to its official foreign policy.

While arising from Britain's own interests in the north and following its own logic, Britain's policy towards Sweden was closely linked to Anglo-American relations, and specifically to the gradual increase of the American interest in northern Europe. This thesis has shown how important this was. Despite the primacy given to the postwar Atlantic 'special relationship', British policy towards Sweden followed a different path 
from 1947 onwards when US interests began to increase. As in many other areas, British diplomacy faced a double challenge: to tie the Americans firmly in the consolidation and defence of Scandinavia economically and militarily - and in terms the Scandinavians themselves could accept - but at the same time to ensure that Britain's own vital interests were not to be compromised. The practical problem was then how to reconcile British and US views over Swedish neutrality policy. This was finally achieved in early 1952 when the Americans officially adopted the same policy Britain had for so long followed. Swedish neutrality was accepted as a part of the cold war Nordic balance. Instead of being a source of weakness it was now seen in a more positive light. As the Americans were more and more directly involved in service to service exchanges with the Swedes, neutrality did not need to be considered dogmatically. The turn in US policy finally brought the two Western powers in step with each other. Here we can see that it was Britain which took a leading role in formulating US perceptions.

What overall influence did British policy have? First, the British advocated this policy from 1947 in both high level political conversations and on the lower working level. It is hard to estimate the precise impact of this slow persuasion. Where this definitely had an effect was in Sweden, where the British attitude was additional proof of the wisdom of the government's policy. In this way it bolstered Swedish resolve. Second, British policy actively eroded the basis for an American policy of isolation of Sweden. Sweden could exploit the situation that a more benevolent British policy created. By opening possibilities for the Swedes to maintain as close relations with the West as possible, British policy increased flexibility for Sweden. Despite a more critical American stance, Sweden was not cut off from supplies of Western armaments technology, military information or from confidential contacts with senior military authorities. Neither was Sweden isolated in questions of economic cooperation, where the direct links with Britain were particularly significant, both in the OEEC and in Uniscan. In the activities of 
COCOM, which was established in 1948 in Paris to control the trade of strategic goods to the Eastern bloc, Sweden could likewise rely on British moderation of more radical American demands. Thus, despite its policy of neutrality, Sweden was increasingly integrated into the Western group of nations, as defined by the cold war, and this was done by functional ties on different levels. The British, by maintaining contacts with the Swedes both in terms of communication and in material terms undercut the potency of US policy.

Neutrality was thus accepted as a legitimate option for a state like Sweden in peacetime. It could be neutral, it could be aligned, it could be something in between: all were perfectly legitimate policies. As a Swedish prime minister from a later day, Olof Palme stressed: Swedish neutrality policy was defined by Sweden, and only by Sweden itself. What powers like Britain could do was to influence the external environment where this took place. But in practice, the external context was as important for Sweden as the visions and goals of its political leaders. Despite the narrow margins of its international influence, British policy was instrumental in establishing the conditions whereby Sweden could reconcile the conflicting requirements of alignment and nonalignment in the cold war.

This does not mean that Britain's involvement in shaping the postwar constellation of power in the Nordic region should be seen as an unqualified success story. The main aim of forging links with Sweden was that enabled it to combine military nonalingment with ideological and economic alignment, and the American acceptance of this approach, was achieved while others had to be reconsidered. The ultimate, albeit distant goal was always Sweden's closer alignment with the West, even at the expense of possibly upsetting the regional balance. The readiness of the British governments to leave Finland in the Soviet sphere, and a willingess to risk its independence as a possible price for Sweden's closer alignment with the West, witnessed that Britain's interests in the Nordic 
region were fairly sharply defined. The cynicism of this policy was not, perhaps fortunately for the Finns, reciprocated by the Americans, who put a higher premium on Finland's continuing independence. On the other hand, Britain's willingness to settle with the regional balance achieved by the outward appearance of Sweden's foreign and defence policies, undoubtedly helped Finland, but should not be confused with the motivations behind this policy.

Britain's main policy failure was, it must be concluded, its inability to maintain its economic position in Scandinavia. The long term economic strategy to integrate Scandinavia as far as possible into the British economy and to keep it closely attached to the sterling area failed. With this went any chances there might have been for bolstering Britain's international political influence, independent from the East-West conflict, with Scandinavian support. While the Americans were adjusting themselves to their new strategic and political role in Scandinavia, Swedish markets were irrevocably lost to the Germans by mid-1950s. With the erosion of Britain's economic relationship with the Swedes and the rest of the region, went any inclination they might have had to supporting sterling or align themselves closer to Britain economically or politically. Neither did economic diplomacy, which Bevin in particular considered such a useful tool to bring Sweden closer to Britain politically, function quite as intended. While the main successes were seen on the institutional front, in the fruitful cooperation in the OEEC and Uniscan consultations, problems in the economy prevented any further steps along the direction of closer Anglo-Scandinavian economic alignment.

Two simultaneous processes defined the overall terms of reference of Britain's relationship with Sweden and the other Scandinavian countries: Britain's own political and economic ambitions concerning its great power status, capacity to independent action internationally and its standing in Europe, and the worsening of relations with the Soviet Union after 1945. The policy of developing relations with the Scandinavians on political 
and economic levels was already visible in British wartime planning and in the first postwar schemes for Britain's policy in Europe. It was not directly dependent on developments in East-West relations. The worsening of relations with the Soviet Union made it more acute and more urgent, but did not alone bring this need about. Even without the cold war, Britain would have had a concern in Scandinavia, arising from its economic interests and international political ambitions. But what has to be stressed, and to assess the debates on the cold war origins, is that it played very little, if any, part in the overall worsening of Anglo-Soviet or East-West relations. The cold war, even the bilateral Anglo-Soviet schism of 1945-46, was not brought about because Britain saw its interests threatened by the Soviet Union in Scandinavia. The fact that Soviet actions elsewhere seemed to threaten British interests in Scandinavia as well, heightened the magnitude of that conflict and by the same token Scandinavia's significance to Britain.

Moreover, the direct link between the cold war and the motivations behind British trade policy in Scandinavia was not strong. The Soviet Union did not pose an economic, but a strategic and political challenge in Scandinavia. A reconstructed Germany was the most likely competitor for Scandinavian markets, alongside the US. In this respect, the connection between British foreign and trade policies had more to do with the internal dynamics of the Western international system than with East-West tension. It was more closely attached to the overall aim of community building in the West, closer cooperation among increasingly interdependent countries, but also economic competition among them. Where the cold war and British economic concerns in Scandinavia met, was when economic cooperation, such as was done in the OEEC, was used to integrate a neutral Sweden to the West for power-political reasons.

But inevitably, although separate from Britain's own ambitions to remain in the rank of first class global powers, the increasing political tension with the Soviet Union made Scandinavia a strategically important area for Britain. What had previously in times of 
peace been an area of concern mostly to businessmen, became an area of great interest to the military as well. Britain's overall aim to develop relations with the Scandinavians was soon linked with the perceived need to prevent the Soviet Union from dilating its sphere of influence beyond the immediate rimlands, such as Finland.

British policy was the result of a variety of interests, represented by the Labour ministers, the economic departments, business and industry, the military planners and the Foreign Office. Labour government's ministers' fundamentally optimistic and positive perception of Scandinavia contributed to the degree that British policy was constrained from siding with the Americans in criticising their sitting on the fence. Sweden and its social democratic leadership enjoyed the confidence and basic sympathies of British Labour. This was an important factor in preventing Bevin from taking a more critical stance towards Undén's policy in 1948. An idealised view of Scandinavia, even a perception of an Anglo-Scandinavian 'special relationship' was shared also more widely, and was not uncommon amongst conservative politicians, business circles, in the economic departments, in the Bank of England and also in the FO. Furthermore, economic and trade interests had nothing to gain, but a lot to lose, from a political rift between the British and Swedish governments over the wisdom of neutrality policy.

Throughout the period studied here, the COS had a crucial role in determining the basic interests the cold war seemed to be threatening in Scandinavia. Its strategic significance was repeatedly stressed by the military chiefs and their conclusion that Swedish resources, even if neutral, were needed and useful in Western defence was heeded by political decisionmakers. In addition to this input to policy-making, the military played an important role also in its implementation. Their role was strengthened even more during the Korean war, due to the central position of British service representatives, such as the service attachés in Stockholm, staff officers in London and in AFNE in confidential exchanges with the Swedes. The FO was aware of the dangers 
involved in giving the military such a free hand in handling of relations with the Swedes, but serious friction was avoided. Being afraid of political trouble either with the Swedish foreign ministry, Soviet criticism or US suspicions before 1952, the FO was also willing to leave the details to the military authorities, as if to ensure the 'non-political' character of the exchanges. In this sense its behaviour mirrored that of Swedish political authorities, who likewise gave their own military considerable freedom in defence planning, so long as it did not overtly compromise government policy.

The Board of Trade and the Treasury, supported by the Bank of England, were in general in agreement with the FO when dealing with Sweden. The great attention given to the economic dimensions of the Anglo-Swedish relationship was only partly due to the substantial commercial and business interests, as economic relations with Sweden were seen in Whitehall to a great extent to be a politically charged issue. Help from Sweden was needed in economic reconstruction and in international economic cooperation, in OEEC politics and in reinstating confidence in sterling. Scandinavian markets were attractive to Board of Trade officials wrestling with the problems of Britain's export trade. But economic issues were relevant also, and especially from the FO point of view, in building up those 'organic ties' underlying the kind of Western unity that was advocated by Bevin. The convergence of the economic departments' interests with those of the FO was seen most clearly when determining the future role of Uniscan in 1950.

Bevin was relatively new to Scandinavian issues when he became foreign secretary and by and large followed the advice of his officials. His main contribution to Britain's Swedish policy came in 1948, when he restrained more hawkish officials from taking too critical a stance towards neutrality. The same applied with his interventions in 1949 and 1950 to secure Sweden the supply of essential raw materials and arms deliveries. Morrison essentially followed Bevin's line and put no pressure whatsoever on the Swedes, although the situation in 1951 might have offered alternative courses of action. 
This conviction was all the more important, as it did contain a serious risk for political trouble with the Americans. In following their own line towards Sweden, both Bevin and Morrison ran this risk, which in the end paid off with the turn of US policy in 1952.

If Bevin at first followed the counsel of his officials, then Eden was even more willing to accept the basic wisdom of the established policy in 1952. In reaffirming Labour's policy Eden showed not only bi-partisanship in the handling of foreign relations, but also a lesser sense of urgency for him to take any specific measures to alter the position. With the US now on the same basic lines there was less need for Eden's active involvement in the political management of the 'Nordic balance'. If changing little, Eden did not contribute much positive new either. His intiative to link the proposed European Defence Community with existing European bodies, namely the Council of Europe, witnessed that he paid less attention to Sweden's or Scandinavian national sensitivities and was less preoccupied than Labour ministers had been with Sweden's institutional connection to the West. Eden's initiative was probably as much an indication of a perception of the firmness of Sweden's basic Western orientation as much as disregard to previous Anglo-Swedish cooperation in European institutions. But with these winds blowing on the top, the value of Uniscan on the official level was heightened in maintaining political goodwill and confidentiality.

In conclusion, before the US government adopted a more positive official attitude, the British remained the primary link between Sweden and the Western alliance. My thesis has shown this to have been the case in almost every aspect of Sweden's Western connection. That was the most important contribution by Britain in the Nordic region in the beginning and during the first phase of the cold war. 


\section{BIBLIOGRAPHY}

Archives:

Public Record Office (PRO), Kew

$\begin{array}{ll}\text { ADM 205 } & \text { First Sea Lord records } \\ \text { AIR 75 } & \text { Official papers of Sir John Slessor } \\ \text { AIR 8 } & \text { Chief of Air Staff papers } \\ \text { BT 11 } & \text { Board of Trade, Commercial Department } \\ \text { CAB 128 } & \text { Cabinet minutes } \\ \text { CAB 129 } & \text { Cabinet memoranda } \\ \text { CAB 131, 134 } & \text { Cabinet Committees } \\ \text { DEFE 4 } & \text { Chiefs of Staff Committee, minutes } \\ \text { DEFE 5 } & \text { Chiefs of Staff Committee, memoranda } \\ \text { FO 371 } & \text { Foreign Office general political correspondence } \\ \text { FO 800 } & \text { Foreign Office private papers } \\ \text { PREM 8 } & \text { Prime Minister's Private Office papers 1945-51 } \\ \text { PREM 11 } & \text { Prime Minister's Private Office papers 1951-64 } \\ \text { T 236 } & \text { Treasury, Overseas Finance Division }\end{array}$

Bank of England Archive, London

OV 29 Country files, Sweden; Financial Relations; AngloScandinavian Regional Group (Uniscan)

Riksarkivet (RA), Stockholm

Försvarsdepartement

F I 181 B Försvarskommittee 1948-49

Utrikesdepartement, 1920 year's dossiersystem:

Hp 1 P Atlantpakten 1951-52

HP $1 \mathrm{Ba} \quad$ Politik: allmänt, Brittiska riket 1945-53

HP 6 Ba Flygattachérapporter, Brittiska riket

HP $64 \AA \quad$ Ekonomisk samverkan mellan Storbritannien och de skandinaviska länderna

Utrikesnämnd
A 2
Memorialprotokoll 
Krigsarkivet, Stockholm

E I, Marinattachén i London, inkommande skrivelser

Regeringskansliets Centralarkiv, Stockholm.

Neutrality Policy Commission's Archive (NPCA)

Utrikesdepartments arkiv (ASMFA), Stockholm

HP $1 \mathrm{Ba} \quad$ Politik: allmänt, Brittiska riket, 1953-54

Historical Archives of the European Communities, Florence

OEEC Archives

Ulkoministeriön arkisto (AFMFA), Helsinki

Reports of the Embassy in London, microfilms $5 \mathrm{C}$

\section{Collections of Private Papers}

Lord Attlee papers, Bodleian Library, Oxford

Ernest Bevin papers, Churchill College, Cambridge

Henry Denham papers, Churchill College, Cambridge

Sir Victor Mallet papers, Churchill College, Cambridge

Sir Roger Stevens papers, Churchill College, Cambridge

Viscount Montgomery of Alamein papers, Imperial War Museum, London

Admiral Sir Patrick Brind papers, Liddel Hart Centre for Military Archives,

King's College, London

Sir Stafford Cripps papers, Nuffield College, Oxford

Helge Jung papers, Krigsarkivet, Stockholm

Nils Swedlund papers, Krigsarkivet, Stockholm

Dag Hammarskjöld papers, Kungliga Biblioteket, Stockholm

Östen Undén papers, Kungliga Biblioteket, Stockholm 


\section{Published Collections of Documents}

Bulletins Statistiques de l'OECE. Commerce Exterieur, Serie I 1928, 1937-1953 (Paris: OEEC, 1954).

Documents on British Policy Overseas (DBPO), Ser. I, Vol. I, BUTLER, RoHAN \& PELLY, M. E. (eds.), (London: HMSO 1984).

DBPO, Ser. I, Vol. VI, Pelly, M. E. \& Yasamee, H. J. \& Hamilton, K. A. (eds.), (London: HMSO, 1990)

Cold War International History Project Bulletin (Washington DC, Woodrow Wilson International Center for Scholars, 1992-).

Foreign Relations of the United States (FRUS) 1947, Vol. III: The British Commonwealth; Europe (Washington: Government Printing Office, 1972).

Foreign Relations of the United States (FRUS) 1948, Vol. III: Western Europe (Washington: United States Government Printing Office, 1974).

House of Commons Debates, 5th Series (London: HMSO, 1948).

House of Lords Debates, 5th Series (London: HMSO, 1948).

Om kriget kommit... Förberedelser för mottagande av militärt bistånd 1949-1969. Betänkande av Neutralitetspolitikkommissionen. Bilagor (Stockholm: Statens offentliga utredningar 1994: 11).

Sven Grafström, Anteckningar 1945-1954, EkMAN, STiG (ed.), (Stockholm: Kungl. Samfundet för utgivande av handskrifter rörande Skandinaviens historia, Handlingar del $15,1989)$.

\section{Newspapers and Journals}

The Financial Times, The Times, Daily Mail, Daily Telegraph, Daily Worker, Manchester Guardian, New York Herald Tribune, The Economist, Telegraph, Ce Matin, The New York Times, The Anglo-Swedish Review, Aftonbladet, Svenska Dagbladet, Dagens Nyheter, Sydsvenska Dagbladet Snällposten, Göteborgs-Posten

\section{Theses}

Cole, Paul M., Neutralité du Jour: The Conduct of Swedish Security Policy since 1945 (unpublished Ph.D.-thesis, Johns Hopkins University, Washington D.C., 1990). TURNER, HOWARD, Britain, the United States and Scandinavian security problems 1945 49 (unpublished Ph.D.-thesis, Aberdeen University, 1982).

\section{Books}

Aalders, Gerald, Swedish Neutrality and the Cold War 1945-49 (Amsterdam, 1989). 
AdLER-KARLSSON, GunNar, Western Economic Warfare 1947-1967. A Case Study in Foreign Economic Policy (Uppsala: Almqvist \& Wiksell, 1968).

AGRELl, WILHELM, Den Stora Lögnen (Stockholm: Ordfront, 1991).

ANDERSON, TERry H., The United States, Great Britain, and the Cold War, 1944-1947 (Columbia: University of Missouri Press, 1981).

ARCHER, Clive, Uncertain Trust. The British-Norwegian Defence Relationship (Oslo: Institute for Defence Studies, 1989).

BARKER, ELISABETH, The British Between the Superpowers 1945-1950 (London: Macmillan, 1983).

BEIJER, CARL-FREDRIK \& BJÖREMAN, CARL, Det försvarspolitiska vägvalet. Handlingsfrihet och nytänkande inför $F B 92$ (Kristianstad: Militärhistoriska Förlaget, 1991), 47 - 50.

BERDAL, MATS, British naval policy and Norwegian Security. Maritime power in transition, 1951-60 (Oslo: Institute for Defence Studies, 1992).

BERDAL, MATS, Forging a maritime alliance. Norway and the evolution of American Maritime Strategy (Oslo: Institute for Defence Studies, 1993).

BERDAL, MATS, The United States, Norway and the Cold War, 1954-60 (London: Macmillan 1997).

BERgMARK, BirgitTA, Stig Wennerström. Spionen som teg (Falun: Bonnier Alba, 1993). Blidberg, Kersti, Just Good Friends. Nordic Social Democracy and Security Policy 1945-50 (Oslo: Institute for Defence Studies, 1987).

BlaXell, LiOnel H., Through the Hawse Pipe (privately printed memoirs, 1990).

Bohlen, Charles E., Witness to History 1929-1969 (New York: Norton, 1973).

BOSSUAT, GÉRARD, La France, l'aide américaine et la construction européenne 19441954, Vol. II (Paris, Comité pour l'historie économique et financière, Ministère des Finances, 1992).

BOWER, TOM, The Red Web. MI6 and the KGB Master Coup (London: Mandarin, 1993). Bullock, ALAN, Ernest Bevin. Foreign Secretary 1945-1951 (London: William Heinemann, 1983).

LORD BUTLER, The Art of the Possible. The Memoirs of Lord Butler (London: Hamish Hamilton, 1971).

CARLGREN, WILHELM M., Svensk utrikespolitik 1939-1945 (Stockholm, Allmänna Förlaget, 1973).

Deighton, Anne, The Impossible Peace: Britain the Division of Germany and the Origins of the Cold War (Oxford: Oxford University Press, 1990).

DeIGHTON, ANNE (ed.), Britain and the First Cold War (London: Macmillan, 1990).

DELL, EDMUND, The Schuman Plan and the British Abdication of Leadership in Europe (Oxford: Oxford University Press, 1995).

DENHAM, HENRY, Inside the Nazi Ring: A Naval Attaché in Sweden 1940-1945 (London: Murray, 1984).

Diebold, William Jr., Trade and Payments in Western Europe. A Study in Economic Cooperation 1947-51 (New York: Harper \& Brothers, 1952).

Due-Nielsen, Carsten \& NoACK, Johan Peter \& Petersen, Nikolaj, (eds.), Danmark, Norden og NATO, 1948-1962 (Copenhagen: Jurist- og Økonomforbundets 
Forlag, 1991).

Eden, AnThony, Full Circle (London: Cassell, 1960).

EDMONDS, RoBIN, Setting the Mould: The United States and Britain 1945-1950 (Oxford: Clarendon Press, 1986).

EKENGREN, ANN-MARIE, Sverige under kalla kriget 1945-1969. En forskningsöversikt (Göteborg: Statsvetenskapliga institutionen, Göteborgs Universitet, 1997).

ERIKSEN, KNUT EINAR, Storbritannia og Baseproblematikken i Norden 1945-1947(Oslo: Forsvarhistorisk Forskningssenter, 1981).

ERIKSEN, KNUT EINAR \& PHARO, HELGE, Norsk sikkerhetspolitikk som etterkrigshistorisk forskningsfelt. Etterkrigshistorisk Register, nr. 21, April 1992 (Bergen: LOS-senteret, 1994).

ERIKsen, Knut Einar \& Pharo, Helge, Norway and the Early Cold War: Conditional Atlantic Cooperation (Oslo: Norwegian Institute for Defence Studies, 1993).

FEIS, HERBERT, Churchill, Roosevelt, Stalin. The War They Waged and the Peace They Sought (Princeton: Princeton University Press, 1957).

FEIS, HERBERT, From Trust to Terror: The Onset of the Cold War, 1945-1950 (New York: Norton, 1970).

Frankel, JoSEPH, British Foreign Policy, 1945-1973 (London: RIIA and Oxford University Press, 1975).

GABRIEL, JÜRG MARTIN, The American Conception of Neutrality after 1941 (London: Macmillan, 1988).

GADDIS, JOHN LEWIS, The United States and the Origins of the Cold War 1941-1947 (New York: Columbia University Press, 1972).

GADDIS, JOHN LEWIS, The Long Peace. Inquiries Into the History of the Cold War (Oxford: Oxford University Press, 1987).

GADDIS, JOHN LEWIS, We Now Know. Rethinking Cold War History (Oxford: Clarendon Press, 1997).

Gilbert, MARTIN, Churchill. A Life (London: Heinemann 1991).

LORD GLADWYN, The Memoirs of Lord Gladwyn (London: Weidenfeld and Nicolson, 1972).

Gillingham, John, Coal, Steel, and the Rebirth of Europe. 1945-1955. The Germans and the French from Ruhr Conflict to Economic Community (Cambridge: Cambridge University Press, 1991).

Greenland during the Cold War. Danish and American Security Policy 1945-68 (Copenhagen: DUPI, 1997).

GREENWOOD, SEAN, Britain and European Cooperation Since 1945 (Oxford: Blackwell, 1992).

GRIFFITHS, RICHARD T. \& LYNCH, FRANCES M. B., The Fritalux/Finebel Negotiations 1949/1950 (Florence: European University Institute, 1984).

Had there been a war... Preparations for the reception of military assistance 1949-1969. Report of the Commission on Neutrality Policy. Translation of SOU 1994: 11, (Stockholm: Statens offentliga utredningar 1994: 11).

HakovirTa, HaRTo, East-West Conflict and European Neutrality (Oxford: Clarendon Press, 1988). 
HAMILTON, KeITH \& LANGHORNe, RichaRD, The Practice of Diplomacy. Its Evolution, Theory and Administration (London: Routledge, 1995).

HANHIMÄKI, JUSSI M., Containing Coexistence, America, Russia, and the "Finnish Solution", 1945-1956 (Kent, Ohio: The Kent State University Press, 1997).

HARBUTT, FRASER J., The Iron Curtain: Churchill, America, and the Origins of the Cold War (New York: Oxford University Press, 1986).

HATHAWAY, ROBERT, Ambiguous Partnership: Britain and America 1944-1947 (New York: Columbia University Press, 1981).

HEALEY, Denis, The Time of my Life (London: Penguin, 1990).

HENNESSY, PETER, Cabinet (Oxford: Basil Blackwell, 1986).

Hogan, MichaEl, The Marshall Plan. America, Britain, and the Reconstruction of Western Europe, 1947-1952 (Cambridge: Cambridge University Press, 1987).

HolbraAd, Carsten, Danish Neutrality. A Study in the Foreign Policy of a Small State (Oxford: Clarendon Press, 1991).

Holloway, David, Stalin and the Bomb. The Soviet Union and Atomic Energy 19391956 (New Haven: Yale University Press, 1994).

HÄGGLÖF, GunNAR, Fredens Vägar (Stockholm: P.A. Norstedt \& Söners, 1973).

HÄGGLÖF, GuNNAR, Engelska àr 1950-1960 (Stockholm: P. A. Norstedt \& Söners Förlag, 1974).

HÄGGLÖF, INGEMAR, Drömmen om Europa (Värnamo: Norstedts, 1987).

JoHANSSON, AlF W., Herbert Tingsten och det kalla kriget. Antikommunism och liberalism i Dagens Nyheter 1946-1952 (Stockholm: Tiden, 1995).

Johnson, Peter, Neutrality. A Policy for Britain (London: Temple Smith, 1985).

JOKIPII, MAUNO, Jatkosodan synty. Tutkimuksia Saksan ja Suomen sotilaallisesta yhteistyöstä 1940-41 (Helsinki: Otava, 1987).

JONTER, THOMAS, Socialisering som kom av sig... Sverige, oljan och USA:s planer på en ny ekonomisk världsordning 1945-1949 (Stockholm: Carlssons, 1995).

JUNGAR, SUNE \& JENSEN, BENT (eds.), Sovjetunionen och Norden - konflikt, kontakt, influenser (Helsinki: Finnish Historical Society, 1997).

KAISER, WOLFRAM, Using Europe, Abusing Europeans. Britain and European Integration, 1945-63 (London: Macmillan, 1996).

KARLSSON, BIRGIT, Handelspolitik eller politisk handling. Sveriges handel med öststaterna 1946-1952 (Göteborg: Institute of Economic History of Gothenburgh University, 1992).

KARSH, EFRAIM, Neutrality and Small States (London: Routledge, 1988).

KENT, JOHN, British Imperial Strategy and the Origins of the Cold War 1944-49 (Leicester: Leicester University Press, 1993).

KIRKPATRICK, IVONE, The Inner Circle (London: Macmillan, 1959).

KOLKO, JOYCE AND GABRIEL, The Limits of Power: The World and United States Foreign Policy 1945 - 1954 (New York: Harper \& Row, 1972).

LACROIX-RIZ, ANNIE, L'économie suédoise entre l'est et l'ouest 1944-1949: Neutralite et embargo, de la guerre au pacte atlantique (Paris: L'Harmattan, 1991).

Leffler, MELVyn P., A Preponderance of Power. National Security, the Truman Administration, and the Cold War (Stanford: Stanford University Press, 1992). 
LESKINEN, JARI, Vaiettu Suomen silta. Suomen ja Viron salainen sotilaallinen yhteistoiminta Neuvostoliiton varalta vuosina 1930-1939 (Helsinki: Finnish Historical Society, 1997).

LEWIS, Julian, Changing Direction. British Military Planning for Post-War Strategic Defence, 1942-47 (London: Sherwood, 1988).

LINDHOLM, RoLF, Sveriges neutralitet. Swedish Neutrality (Lund: Juridiska Föreningen i Lund, 1987).

LouIS, WILliam Roger, The British Empire in the Middle East 1945-1951. Arab Nationalism, the United States, and Postwar Imperialism (Oxford: Oxford University Press, 1984).

Ludlow, N. PIERS, Dealing with Britain. The Six and the First UK Application to the EEC (Cambridge: Cambridge University Press, 1997).

LUNDESTAD, GeIR, America, Scandinavia, and the Cold War 1945-1949 (New York: Columbia University Press, 1980).

LUNDESTAD, GEIR, The American "Empire", and Other Studies of US Foreign Policy in a Comparative Perspective (Oxford \& Oslo: Oxford University Press and Norwegian University Press, 1990).

MAGILL, J.H., Tasavalta tulikokeessa. Muistelmia Suomesta kuuman ja kylmän sodan vuosilta (Mikkeli: Weilin +Göös, 1981).

MaIer, Charles S. (ed.), The Cold War in Europe. Era of a Divided Continent (Princeton: Markus Wiener Publishers, 3rd ed., 1996).

AF MALMBORG, MIKAEL, Den ständaktiga nationalstaten. Sverige och den västeuropeiska integrationen 1945-1959 (Lund: Lund University Press, 1994).

MILWARD, ALAN, The Reconstruction of Western Europe 1945-1951 (London: Routledge, 1987).

MOLIN, KARL, Omstridd neutralitet. Experternas kritik av svensk utrikespolitik 1948-1950 (Stockholm: Tiden 1991).

MoRgan, Kenneth O., Labour in Power, 1945-1951 (Oxford: Clarendon Press, 1984).

MöLLER, YNGVE, Östen Undén. En biografi (Stockholm: Norstedts, 1986).

Nedskjutningen av DC 3-an i juni 1952. Rapport frän DC 3-utredningen (Stockholm: Utrikesdepartementet, Ds 1992:5, 1992).

NEVAKIVI, JUKKA, Maanalaista diplomatiaa vuosilta 1944-1948 jolloin kylmä sota teki tuloaan pohjolaan (Helsinki: Tammi 1983).

NeVAKIVI, JuKKa, Finnish-Soviet relations 1944-48 (Helsinki: Department of Political History, University of Helsinki, 1994).

NevaKIVI, JUKKa, Zdanov Suomessa. Miksi meitä ei neuvostoliittolaistettu (Helsinki: Otava, 1995).

NILSON, BENGT, Handelspolitik under skärpt konkurrens. England och Sverige 1929-1939 (Lund: Bibliotheca Historica Lundensis LVII, 1983).

NOREEN, ERIK, Brobygge eller blockbildning? De norska och svenska utrikesledningarnas säkerhetspolitiska föreställningar 1945-1948 (Stockholm: Carlssons, 1994).

OGLEY, RODERICK, The Theory and Practice of Neutrality in the Twentieth Century, (London: Routledge \& Kegan Paul, 1970).

Olesen, ThORSTEN B. (ed.), Interdependence Versus Integration. Denmark, Scandinavia 
and Western Europe 1945-1960 (Odense University Press, 1995).

Om kriget kommit... Förberedelser för mottagande av militärt bistånd 1949-1969.

Betänkande av Neutralitetspolitikkommissionen. SOU 1994: 11 (Stockholm: Statens offentliga utredningar, 1994: 11).

OVENDALE, RITCHIE, The English-speaking Alliance: Britain, and the United States, the Dominions and the Cold War, 1945-1951 (London: Allen \& Unwin, 1985).

Ovendale, RitchIE (ed.), British Defence Policy since 1945 (Manchester: Manchester University Press, 1994).

Petersson, Bo, The Soviet Union and Peacetime Neutrality in Europe. A Study of Soviet Political Language (Gothenburg: MH Publishing, 1990).

PETERSSON, Bo, Med Moskvas Ögon. Bedömningar av svensk utrikespolitik under Stalin och Chrusjtjov (Smedjebacken: Arena, 1994).

PETERSSON, LENNART, Svensk utrikeshandel 1871-1980. En studie i den intraindustriell handelns framväxt (Lund: Lund Economic Studies Number 30, 1984).

PETERSEN, NikolaJ, Britain, the United States and Scandinavian Defence 1945-1949 (Aarhus: Institute of Political Science, University of Aarhus, 1980).

PHARO, HElge, Norge, Norden og europeisk integrasjon som etterkrigshistorisk forskningsfelt. Etterkrigshistorisk Register, nr 22, September 1991 (Bergen: LOS-senteret, 1994).

PhARO, Helge \& ERIKSEn, KNUT EINAR, Kald Krig og internasjonalisering, Norsk utenrikspolitikks historie (Oslo: Cappelen, 1997).

Polvinen, TUOMO, Between East and West: Finland in International Politics 1944-1947 (Minneapolis: University of Minnesota Press, 1986).

RautKallio, Hannu, Paasikivi vai Kekkonen. Suomi lännestä nähtynä 1945-1956 (Helsinki: Tammi 1990).

Riste, OlaV, "London-Regjeringa". Norge i krigsalliansen 1940-1945, Vol 1, 19401942: Provetid (Oslo: Det Norske Samlaget, 1973); Vol 2, 1942-1945. Vegen heim (Oslo: Det Norske Samlaget, 1979).

ROBERTS, FrANK, Dealing with Dictators. The Destruction and Revival of Europe 193070 (London: Weidenfeld \& Nicolson 1991).

RoTHWELl, VICTOR, Britain and the Cold War 1941-1947 (London: Jonathan Cape, 1982).

RuIN, OLOF, Tage Erlander. Serving the Welfare State 1946-1969 (Pittsburgh: University of Pittsburgh Press, 1990).

RYAN, HENRY BUTTERFIELD, The Vision of Anglo-America. The US-UK Alliance and the Emerging Cold War, 1943-1946 (Cambridge: Cambridge University Press, 1987).

SALMON, PATRICK, Scandinavia and the Great Powers 1890-1940 (Cambridge, Cambridge University Press, 1997).

The Scandinavian States and Finland. A Political and Economic Survey (London: Royal Institute of International Affairs, 1951).

SEVÓN, CAY, Visionen om Europa. Svensk neutralitet och europeisk återuppbyggnad 1945-1948 (Helsinki: Suomen Historiallinen Seura, 1995).

SKODVIN, MAGNE, Norden eller NATO? Utenriksdepartementet og alliansespörsmalet 1947-49 (Oslo: Universitetsforlaget, 1971). 
Skodvin, Magne, Nordic or North Atlantic Alliance? The Postwar Scandinavian Security Debate (Oslo: Institute for Defence Studies, 1990).

STECKZÉN, BIRGER, Svenskt och brittiskt. Sex essayer (Stockholm: Gebers, 1959).

STEEN-JOHNSSON, CECILIA, Ett folkbedrägeri. DC 3:an och svensk säkerhetspolitik. Sverige och Nato 1952-1992 (Stockholm: Carlssons, 1992).

STRȦTH, Bo, Nordic Industry and Nordic Economic Cooperation. The Nordic Industrial Federations and the Nordic Customs Union Negotiations 1947-1959 (Stockholm: Almqvist \& Wiksell International, 1978).

TAMnES, Rolf, The United States and the Cold War in the High North (Aldershot: Dartmouth, 1991).

TAYLOR, PETER J., Britain and the Cold War: 1945 as Geopolitical Transition (London: Pinter, 1990).

Thomsen, BIRgit Nüchel (ed.), The Odd Man Out? Danmark og den Europaiske integration 1948-1992 (Odense: Universitetsforlag 1993).

UdgaARd, Nils Morten, Great Power Politics and Norwegian Foreign Policy. A Study of Norway's Foreign Relations November 1940 - February 1948 (Oslo: Universitetsforlaget 1973).

VILlAUME, POUL, Allieret med forbehold. Danmark, NATO og den kolde krig. En studie $i$ dansk sikkerhedspolitik,(Copenhagen: Eirene 1995).

WAHLBÄCK, KRISTER, The Roots of Swedish Neutrality (Stockholm: Swedish Institute of International Affairs, 1986).

WATt, DONALD CAMERON, How War Came: The Immediate Origins of the Second World War, 1938-1939 (London: William Heinemann, 1989).

Williams, William APPleman, The Tragedy of American Diplomacy (New York: Dell, 1959).

Woods, NGaIRE (ed.), Explaining International Relations Since 1945 (Oxford: Oxford University Press, 1996).

YERgin, DANIEL, The Shattered Peace: The Origins of the Cold War and the National Security State (Boston: Houghton Mifflin, 1977).

Ylitalo, J. RAYMOND, Salasanomia Helsingistä Washingtoniin. Muistelmia ja dokumentteja vuosilta 1946-48 (Helsinki: Otava, 1978).

YOUNG, JOHN W., Britain, France and the Unity of Europe 1945-1951 (Leicester: Leicester University Press, 1984).

YoUNG, JOHN W., Britain and European Unity, 1945-1992 (London: Macmillan, 1993). ZETTERBERG, KENT (ed.), Hotet från Öster. Tre studier om svensk säkerhetspolitik, krigsplanering och strategi $i$ det kalla krigets första fas 1945-1958 (Stockholm: Försvarshögskolan, 1997).

Zubok, Vladislav \& Pleshakov, Constantine, Inside the Kremlin's Cold War. From Stalin to Khrushchev (Cambridge, Mass.: Harvard University Press, 1996).

ÅsTRÖM, SVERKER, Ögonblick. Frän ett Halvsekel i UD-tjänst (Stockholm: Bonnier Alba 1992). 


\section{Articles}

AALDERS, GERALD, 'The failure of the Scandinavian defence union, 1948-1949', Scandinavian Journal of History, Vol. 15, No. 1 (1990), 125 - 153.

AGRELL, WilhelM, 'Sverige tappade kontrollen', Dagens Nyheter 18.1.1990.

AGRELL, WILHELM, 'Vem styr "Firman"', Dagens Nyheter 19.11.1990.

ANDRÉn, NILS, 'On the Meaning and Uses of Neutrality', Cooperation and Conflict, Vol. 26, No. 2 (1991), 67 - 83.

ANDRÉN, NiLS, 'Den mångtydiga neutraliteten', Internationella Studier, No. 2 (1991), $27-48$.

BARBEZAT, DANIEL, 'The Marshall Plan and the Origin of the OEEC', Richard T. Griffiths (ed.), Explorations in OEEC History (Paris: OEEC, 1997), 33 - 47.

BERNTSON, LENNART, 'Naivitetens och den dubbla bokföringens neutralitet', Sydsvenska Dagbladet Snällposten, 1.6.1992.

BRING, OVE, 'Neutralitet contra kollektiv säkerhet', The Royal Swedish Academy of War Sciences, Proceedings and Journal, Vol. 196, (1992), 423 - 329.

Brodin, Katarina \& Goldmann, KJell \& LANGE, Christian, 'The Policy of Neutrality: Official Doctrines of Finland and Sweden', Cooperation and Conflict, Vol. 3, No. 1 (1968), 18 - 51.

Brundtland, ARne Olav, 'The Nordic Balance. Past and Present', Cooperation and Conflict, Vol. 1, No. 2 (1966), 30 - 63.

COBBS HofFMAN, EliSABETH, 'Diplomatic History and the Meaning of Life: Toward a Global American History', Diplomatic History, Vol. 21, No. 4 (1997), 499 - 518.

Cole, PaUl M., 'USA-samarbetet hemlighölls', Dagens Nyheter, 21.10.1990.

Cole, Paul M., 'Neutraliteten gavs upp', Dagens Nyheter 31.10.1990.

Cole, Paul M., 'Lysande mörkläggning', Dagens Nyheter 3.2.1991.

DALGAS JENSEN, LEON, 'Denmark and the Marshall Plan, 1947-48: the Decision to Participate', Scandinavian Journal of History, Vol. 14, No. 1 (1989), 57 - 83.

DÖRFER, INGEMAR, 'Swedish Dependence on Western Military Technology during the Cold War', unpublished paper presented at the conference, 'The Nordic Countries in the Shadow of the Cold War', Danish Institute of International Affairs, Copenhagen 5-7 March 1998.

ERIKSEN, KNUT EINAR, 'Nato, Norden og "den utro tjener" Halvard Lange', Internasjonal Politikk, Vol. 35, No. 2 (1977), 261 - 302.

ERIKSEN, KNUT EINAR \& SKODVIN, MAGNE, 'Storbritannia, NATO og et skandinavisk forbund', Internasjonal Politikk, Vol. 39, No. 3 (1981), 437 - 511.

FRITZ, MARTIN, 'Turbulente Jahre. Schwedens Außenhandel und Wirtschaft 1945-1954', Ulf Olsson (ed.), Neuanfang. Beziehungen zwischen Schweden und Deutschland 19451954. Sieben Beiträge (Umeà: Umeả Studies in Economic History 13, 1990), 143 - 164. GADDIS, JOHN LEWIS, 'The Emerging Post-Revisionist Thesis on the Origins of the Cold War', Diplomatic History, Vol. 7, No.3 (1983), 171 - 190.

GADDIS, JoHn LEwIS, 'The Tragedy of Cold War History', Diplomatic History, Vol. 17, No. 1 (1993), 1 - 16.

GREENWOOD, SEAN, 'The Third Force in the Late 1940s', Brian Brivati \& Harriet Jones 
(eds.), From Reconstruction to Integration: Britain and Europe since 1945 (Leicester: Leicester University Press, 1993), 59 - 70.

GROSBOIS, THIERRY, The European policy of Belgium and Luxembourg, from the war to the cold war and the attitude of Britain, 1943-48, (unpublished paper in the conference 'Britain and the Cold War', Institute of Historical Research, London, 15 - 18 July 1997). GuILloU, JAN, 'Opportunism som statskonst', Sydsvenska Dagbladet Snällposten, 15.2.1994.

GUMMERSSON, JONAS \& KANGER, THOMAS, 'Sanningen om den svenska neutraliteten', Aftonbladet 3.12.1990.

HANHIMÄKI, JUSSI M., 'The First Line of Defence or a Springboard for Disintegration? European Neutrals in American Foreign and Security Policy, 1945-61', Diplomacy and Statecraft, Vol. 7, No. 2 (1996), 378 - 403.

HOLMSTRÖM, MIKAEL, 'Nato-hjälp redan före angrepp', Svenska Dagbladet, 9.2.1994. HOLMSTRÖM, MIKAEL \& LINDMARKER, INGMAR, 'Nato fick Sveriges försvarsplaner', Svenska Dagbladet, 8.2.1994.

HOLMSTRÖM, MIKAEL, 'Fast förbindelse med USA:s flygvapen' \& 'Stor skillnad mellan politik och retorik', Svenska Dagbladet, 13.2.1994.

HOLMSTRÖM, MIKAEL, 'Marinchef i exil skulle försvara riket', Svenska Dagbladet, 22.3.1998.

JOHANSSON, ALF W., 'Sverige och västmakterna 1939-1945', Stig Ekman (ed.), Stormaktstryck och småstatspolitik. Aspekter på svensk politik under andra världskriget (Stockholm: Liber, 1986).

JOHANSSON, ALF W., 'Undén var bitter över påtryckningar', Svenska Dagbladet, 20.5.1994.

JÖRBERG, LENNART \& KRANTZ, Olle, 'Scandinavia', Carlo M. Cipolla (ed.), The Fontana Economic History of Europe. Vol. 6: 1914-1970, Contemporary Economies (London: Collins/Fontana, 1980).

KARLSSON, BIRGIT, 'Neutraliteten - feg eller falsk', Göteborgs-Posten, 21.7.1991.

KARLSSON, BIRGIT, 'Neutrality and Economy: The Redefining of Swedish Neutrality, 1946-52', Journal of Peace Research, Vol. 32 No. 1, (1995), 37 - 48.

KENT, JOHN \& YOUNG, JOHN W., 'The "Western Union" concept and British defence policy, 1947-48', Richard Aldrich (ed.), British Intelligence, Strategy and the Cold war, 1945-51 (London: Routledge, 1992), 166 - 192.

KENT, MARIAN, 'British Foreign Policy and Belgian Neutrality 1936-1940', Jukka Nevakivi (ed.), Neutrality in History. La neutralité dans l'historie (Helsinki: Finnish Historical Society, 1993), 173 - 185.

KorobochKIN, MAXIM, 'Soviet Policy Toward Finland and Norway, 1947-1949, Scandinavian Journal of History, Vol. 20, No. 3 (1995), 185 - 207.

KUBU, MERT, 'Svensk militär grundlurades', Dagens Nyheter, 2.1.1998.

LEIFLAND, LEIF, "They must get in before the end". Churchill och Sverige 1944 och 1945', Mats Bergquist, Alf W. Johansson \& Krister Wahlbäck (eds.), Utrikespolitik och historia. Studier tillägnade Wilhelm M. Carlgren den 6 maj 1987 (Stockholm: Militärhistoriska Förlaget, 1987), 113 - 143.

LEIFLAND, LEIF, 'Kommissionen står på mycket fast mark', Svenska Dagbladet, 


\subsubsection{4.}

LOTH, WILFRIED, 'The Formation of the Blocs: Structures of the East-West Conflict, 1948-50', Norbert Wiggershaus \& Roland C. Foerster (eds.), Western Security Community, 1948-1950. Common Problems and Conflicting National Interests during the Foundation Phase of the North Atlantic Alliance. (Oxford: Berg, 1993).

LuDLOW, PETER, 'Britain and Northern Europe, 1940-1945', Scandinavian Journal of History, Vol. 4, No. 2 (1979), 123 - 162.

MAGNUSSON, ERIK, 'Sverige skulle tvingas med i Nato', Sydsvenska Dagbladet Snällposten, 28.10.1989.

MAJANDER, MIKKO, 'The Limits of Sovereignty. Finland and the Question of the Marshall Plan in 1947', Scandinavian Journal of History, Vol. 19, No. 4 (1994), 309 326.

Molin, KaRL, 'Winning the Peace: Vision and Disappointment in Nordic Security Policy, 1945-49', Henrik S. Nissen (ed.), Scandinavia during the Second World War (Minneapolis: The University of Minnesota Press, 1983), 324 - 382.

MÖLLER, YNGVE, 'Ingen kapitulation', Dahens Nyheter 27.11.1990.

NEVAKIVI, JUKKA, 'Scandinavian Talks on Military Cooperation in 1946-1947: A Prelude to the Decisions of 1948-1949', Cooperation and Conflict, Vol. 19, No. 2 (1984), 165 175.

NEVAKIVI, JUKKA, 'A Decisive Armistice 1944-47: Why Was Finland Not Sovietized?', Scandinavian Journal of History, Vol. 19, No. 2 (1994), 91 - 115.

NEVAKIVI, JUKKA, 'Kekkonen, the Soviet Union and Scandinavia - Aspects of Policy in the Years 1948-1965', Scandinavian Journal of History, Vol. 22, No. 2 (1997), 65 - 81. Nilson, BENGT, 'Butter, Bacon and Coal: Anglo-Danish Commercial Relations, 194751', Scandinavian Journal of History, Vol. 13, No. 3 (1988), 257 - 77.

NiLSON, BENGT, 'Vi spelade dubbelt', Dagens Nyheter 6.11.1990.

NILSON, BENGT, 'No Coal without Iron Ore. Anglo-Swedish trade relations in the shadow of the Korean War', Scandinavian Journal of History, Vol. 16, No. 1 (1991), $45-72$.

NiLSON, BENGT, Undéns tredje väg: Sverige i det kalla kriget, 1950-1952, Scandia, Vol. 60, No. 1 (1994), 67 - 97.

NiLSON, BENGT, 'Undéns tredje väg under det kalla kriget. Sverige kryssade framgångsrikt mellan blindskären', Svenska Dagbladet, 9.5.1994.

OLESEN, THORSTEN BORRING, 'Brødrefolk, men ikke våbenbrødre - diskussionerne om et skandinavisk forsvarsforbund 1948-49', Den jyske Historiker Nr. 69-70 (1994), 151 -178 .

Petersen, NikolaJ, 'Britain, Scandinavia and the North Atlantic Treaty 1948-49', Review of International Studies, Vol. 8, No. 4 (1982), 251 - 268.

Pharo, Helge, 'Det nordatlantiske samarbeid of Norge', Internasjonal Politikk, Vol. 34, No. 4 (1976), 859 - 897.

PhARo, Helge, 'Bridgebuilding and Reconstruction, Norway faces the Marshall Plan', Scandinavian Journal of History, Vol. 1, No. 1 (1976), 125 - 153.

PhARo, Helge, 'Scandinavia', David Reynolds (ed.), The Origins of the Cold War in Europe. International Perspectives (New Haven: Yale University Press, 1994), 194 - 
222.

SAlMON, PATrick, 'British Attitudes towards Neutrality in the Twentieth Century', Jukka Nevakivi (ed.), Neutrality in History. La neutralité dans l'historie (Helsinki: Finnish Historical Society, 1993), 117 - 132.

SALMON, PATRICK, 'Great Britain and Northern Europe from the Second World War to the Cold War', R. Bohn \& Jürgen Elvert (eds.), Kriegsende im Norden. Vom Heißen zum kalten Krieg (Stuttgart: Franz Steiner Verlag, 1995), 197 - 215.

SCHINDLER, DIETRICH, 'Aspects contemporains de la neutralité', Academie de Droit International. Recueil des Cours, 1967 Vol. II, Tome 121 de la collection (Leyden: A. W. Sijthoff, 1969).

SMITH, RAYMOND, 'Ernest Bevin, British Officials and British Soviet Policy, 1945-47', Anne Deighton (ed.), Britain and the First Cold War (London: Macmillan, 1990), 32 52.

SØRENSEN, VIBEKE, 'Economic Recovery versus Containment: The Anglo-American Controversy over East-West Trade, 1947-51', Cooperation and Conflict, Vol. 24, No. 1 (1989), 69 - 97.

WAHLBÄCK, KRISTER, 'Sverige och det skandinaviska försvarsförbundet: Sju förklkaringsfaktorer', Due-Nielsen et al (eds.), Danmark, Norden og NATO, 45 - 57.

WAHLBÄCK, KRISTER, 'Aderton missförstånd om svensk säkerhetspolitik', Internationella Studier, No. 3, hösten 1995, 37 - 80.

WAHLBÄCK, KRISTER, 'Neutralitet och solidaritet. Ett dilemma i svensk säkerhetspolitik 1920-1996', Leif Leifland (ed.), Brobyggare. En vänbok till Nils Andrén (Stockholm: Nerenius \& Santérus, 1997).

WARNER, GEOFFREY, 'The Labour Governments and the Unity of Western Europe, 1945-51, Ritchie Ovendale (ed.), The Foreign Policy of the British Labour Governments 1945-1951 (Leicester: Leicester University Press, 1984), 61 - 82.

WARNER, GEOFFREY, 'The Study of Cold War Origins', Diplomacy and Statecraft, Vol. 1, No. 3 (1990), 13 - 26.

WARNER, GEOFFREY, 'Ernest Bevin and British Foreign Policy, 1945-1951', Gordon A. Craig \& Francis L. Loewenheim (eds.), The Diplomats 1939-1979 (Princeton: Princeton University Press, 1994), 103 - 134.

Watt, Donald CAMERon, 'Rethinking the Cold War: A letter to a British Historian', Political Quarterly, Vol. 49, No. 4 (1978), 446 - 456.

WATt, DONALD CAMERON, review of Deighton, Britain and the First Cold War, International Affairs, Vol. 67, No. 1 (1991), 163 - 165.

ȦsTröM, SVERKER, 'Undén ingen Mr. Hyde', Dagens Nyheter 7.11.1990.

ȦSTRÖM, SVERKER, 'Fram med bevisen!', Dagens Nyheter 5.1.1991.

ȦSTRÖM, SVERKER, 'Kampanj utan kunskap', Dagens Nyheter 21.2.1991.

ȦSTRÖM, SVERKER, 'Erlander kan inte anklagas för medveten lög', Svenska Dagbladet, 23.2.1994.

ẢsTRÖM, SVERKER, 'Erlander kunde ha uttryckt sig klarare', Svenska Dagbladet, 23.3.1994. 